\title{
ny
}

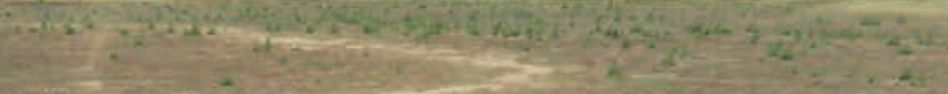

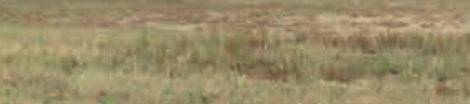

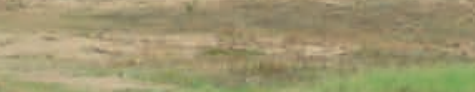

$\frac{100}{20}$

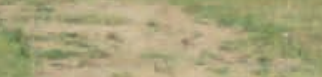
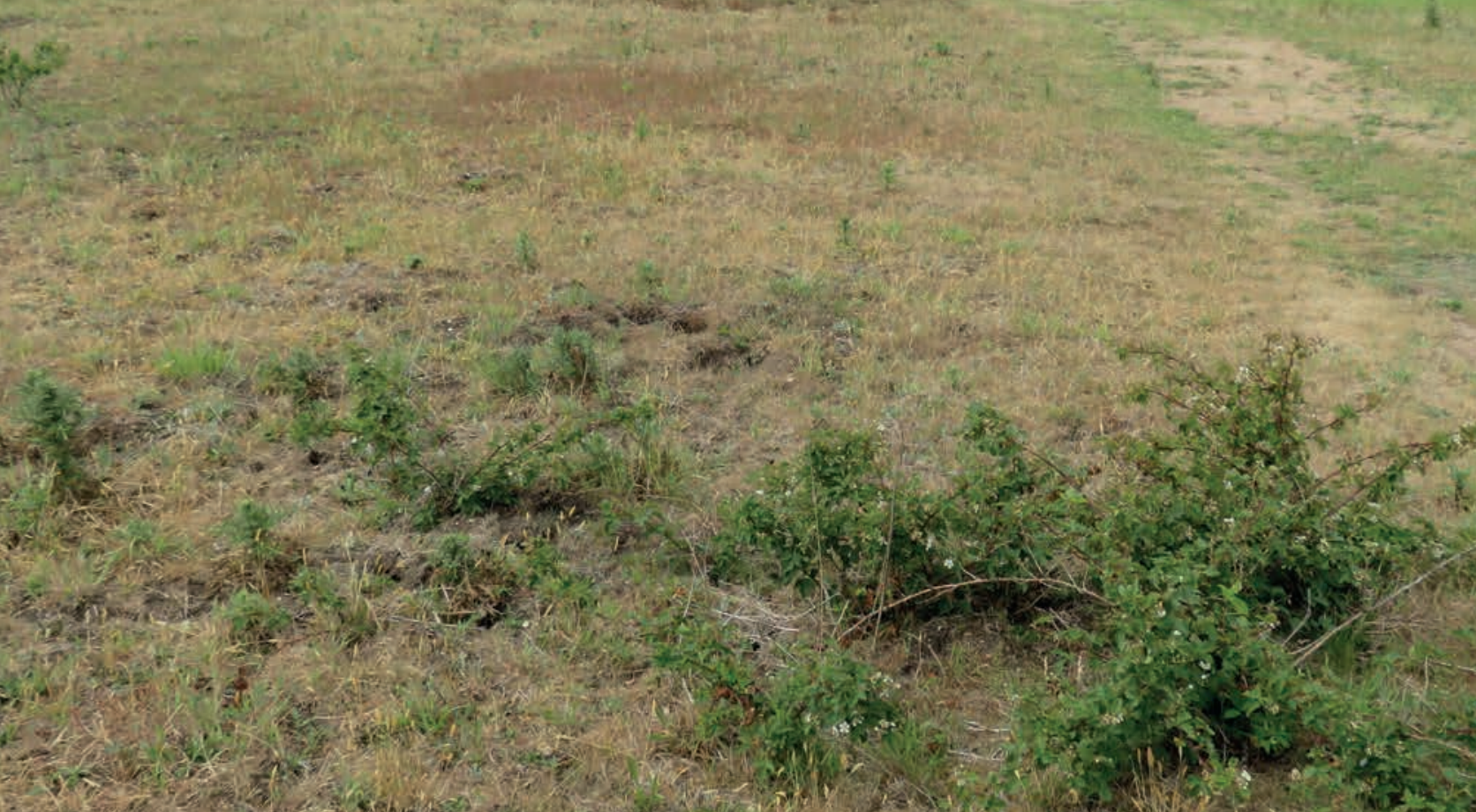

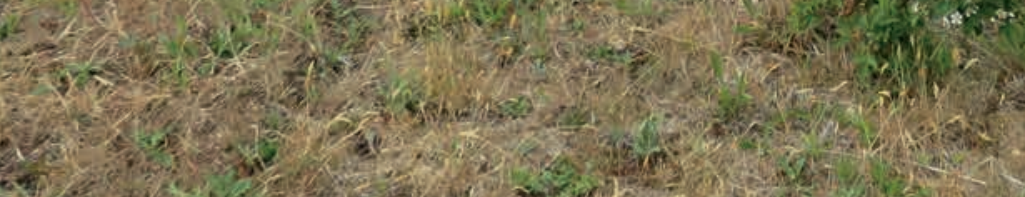

\section{Ecologisch beoordelingskader voor herstelprogramma's Natura 2000 Veluwe}





\title{
Ecologisch beoordelingskader voor herstelprogramma's Natura 2000 Veluwe
}

R.J. Bijlsma ${ }^{1}$, S.P.J. van Delft ${ }^{1}$, J.A.M. Janssen ${ }^{1}, H$. Sierdsema $^{2}$ \& H. Siepel $^{3}$

\author{
1 Wageningen Environmental Research \\ 2 Sovon Vogelonderzoek Nederland \\ 3 Radboud University Nijmegen
}

Dit onderzoek is uitgevoerd door Wageningen Environmental Research in opdracht van en gefinancierd door de Provincie Gelderland.

Wageningen Environmental Research

Wageningen, oktober 2020

Gereviewd door:

A.T. Kuiters, senior onderzoeker WENR

Akkoord voor publicatie:

N.A.C. Smits, teamleider VBL 
R.J. Bijlsma, S.P.J. van Delft, J.A.M. Janssen, H. Sierdsema \& H. Siepel, 2020. Ecologisch beoordelingskader voor herstelprogramma's Natura 2000 Veluwe. Wageningen, Wageningen Environmental Research, Rapport 3036. 114 blz.; 12 fig.; 13 tab.; 81 ref.

Dit rapport geeft beoordelingsformulieren ('formats') voor Natura 2000-habitattypen en leefgebieden van soorten van de herstelprogramma's voor bos en heide \& stuifzand op de Veluwe. De criteria sluiten aan op de systematiek van Standaardgegevensformulieren. Streefbeelden voor de omvang en het goed functioneren van habitattypen en populaties van soorten worden onderbouwd. De beoordeling van landschappelijke positie en abiotische randvoorwaarden van habitattypen en leefgebieden is gekoppeld aan een nieuw vervaardigde Landschappelijke Bodemkaart van het Natura 2000-gebied Veluwe. Kenmerken van de beoordelingsklasse Goed voor habitattypen vormen een referentie voor 'natuurlijke' processen en relaties met bijbehorende structuur. Deze kenmerken zijn nodig voor duurzame instandhouding van habitattypen en populaties. De beoordelingsklasse Optimaal voor geschiktheid van leefgebied en duurzaamheid van populaties correspondeert met toplocaties. Er is een leidraad uitgewerkt voor het in kaart brengen van knelpunten, kansen en maatregelen voor herstel. Deze leidraad kan samen met de beoordelingsformats worden gebruikt tijdens deelgebiedssessies met terreinbeheerders.

Trefwoorden: Natura 2000, Veluwe, landschap, bossen, heiden, stuifzanden, habitattypen, leefgebieden, structuur, functie

Dit rapport is gratis te downloaden van https://doi.org/10.18174/532541 of op www.wur.nl/environmental-research (ga naar 'Wageningen Environmental Research' in de grijze balk onderaan). Wageningen Environmental Research verstrekt geen gedrukte exemplaren van rapporten.

2020 Wageningen Environmental Research (instituut binnen de rechtspersoon Stichting Wageningen Research), Postbus 47, 6700 AA Wageningen, T 03174807 00, www.wur.nl/environmental-research. Wageningen Environmental Research is onderdeel van Wageningen University \& Research.

- Overname, verveelvoudiging of openbaarmaking van deze uitgave is toegestaan mits met duidelijke bronvermelding.

- Overname, verveelvoudiging of openbaarmaking is niet toegestaan voor commerciële doeleinden en/of geldelijk gewin.

- Overname, verveelvoudiging of openbaarmaking is niet toegestaan voor die gedeelten van deze uitgave waarvan duidelijk is dat de auteursrechten liggen bij derden en/of zijn voorbehouden.

Wageningen Environmental Research aanvaardt geen aansprakelijkheid voor eventuele schade voortvloeiend uit het gebruik van de resultaten van dit onderzoek of de toepassing van de adviezen.

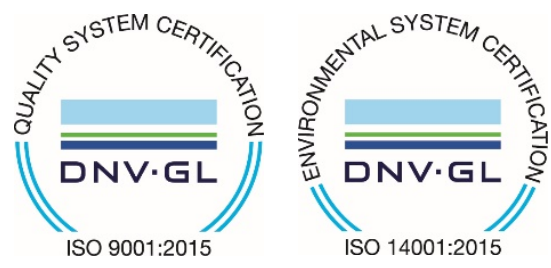

Wageningen Environmental Research werkt sinds 2003 met een ISO 9001 gecertificeerd kwaliteitsmanagementsysteem. In 2006 heeft Wageningen Environmental Research een milieuzorgsysteem geïmplementeerd, gecertificeerd volgens de norm ISO 14001.

Wageningen Environmental Research geeft via ISO 26000 invulling aan haar maatschappelijke verantwoordelijkheid.

Wageningen Environmental Research Rapport 3036 | ISSN 1566-7197

Foto omslag: Wolfheze, Reijerskamp (Rienk-Jan Bijlsma) 


\section{Inhoud}

$\begin{array}{ll}\text { Verantwoording } & 5\end{array}$

$\begin{array}{ll}\text { Woord vooraf } & 7\end{array}$

$\begin{array}{ll}\text { Samenvatting } & 9\end{array}$

1

$\begin{array}{lr}\text { Inleiding } & 11\end{array}$

1.1 Achtergrond 11

1.2 Doelstelling $\quad 12$

$\begin{array}{lll}1.3 & \text { Werkwijze op hoofdlijnen } & 12\end{array}$

1.3.1 Stap 1. Opstellen van een beoordelingskader en een synthesedocument $\begin{array}{ll}\text { voor gebiedssessies } & 12\end{array}$

1.3.2 Stap 2. Deelgebiedssessies met beheerders 13

1.3.3 Stap 3. Veluwe-brede prioritering van maatregelen 13

$\begin{array}{lll}1.4 & \text { Leeswijzer } & 13\end{array}$

$\begin{array}{ll}\text { Beoordelingskader } & 14\end{array}$

2.1 Gebruikte termen: format, criterium en maatlat $\quad 14$

2.2 Relatie met Natura 2000-rapportages 14

2.2.1 Criteria voor ecologische beoordeling in (deel)gebieden 14

2.2.2 Karakteristieke soorten van habitattypen $\quad 15$

2.2.3 Natura 2000-gebied en deelgebieden 16

$\begin{array}{lll}2.3 & \text { Beoordelingsklassen, referenties en scores } & 17\end{array}$

$\begin{array}{ll}2.3 .1 \text { Beoordelingsklassen habitattypen } & 17\end{array}$

$\begin{array}{ll}\text { 2.3.2 Beoordelingsklassen leefgebieden } & 17\end{array}$

2.3.3 Referenties: Goed en Optimaal 18

2.3.4 Beoordeling: ruimtelijke schaal en wijze van scoren 18

2.3.5 Databronnen voor beoordeling 19

2.4 Beoordelingscriteria habitattypen $\quad 20$

2.4.1 Landschappelijke positie en samenhang 20

$\begin{array}{ll}2.4 .2 & \text { Oppervlaktebehoefte } \\ 2.4 .3 & 21\end{array}$

2.4.3 Structuur en functie: decor versus spel en spelers $\quad 22$

2.4.4 Structuur en functie op de Veluwe $\quad 24$

2.4.5 Maatlatten voor de beoordeling van structuur $\quad 24$

2.4.6 Maatlatten voor de beoordeling van functie $\quad 25$

$\begin{array}{ll}2.4 .7 \text { Karakteristieke soorten en vegetatietypen } & 27\end{array}$

2.5 Beoordelingscriteria leefgebieden $\quad 28$

2.5.1 Ruimtelijke condities en populatiekenmerken (literatuuroverzicht) $\quad 28$

2.5.2 Toelichting bij beoordelingsformats vogels 28

2.6 Bodemkwaliteit en voedselkwaliteit voor de fauna $\quad 29$

$\begin{array}{lll}2.7 & \text { Grote eenheden natuur in het zandlandschap } & 29\end{array}$

$\begin{array}{lll}2.8 & \text { Potentieel habitattype en leefgebied } & 30\end{array}$

3 Toepassen van beoordelingskader in deelgebieden (gebiedssessies)

4.1 Doel en werkwijze $\quad 32$

4.2 Indeling van FG-regio Hogere zandgronden (focus Veluwe) 33

4.2.1 HzG Glaciale gebieden $\quad 35$

4.2.2 HzS Stuifzandgebieden 39

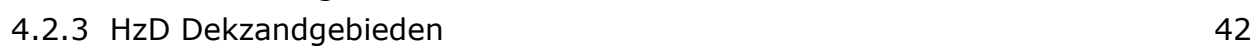


$\begin{array}{lll}5.1 & \text { Achtergrond en werkwijze } & 45\end{array}$

5.2 Bestanden (afgeleid van) historisch kaartmateriaal $\quad 48$

$\begin{array}{ll}\text { Literatuur } & 49\end{array}$

Bijlage 1 Beoordelingsformats habitattypen $\quad 53$

Bijlage 2 Beoordelingsformats leefgebieden broedvogels 69

$\begin{array}{lll}\text { Bijlage } 3 & \text { Karakteristieke flora van habitattypen } & \mathbf{8 1}\end{array}$

Bijlage 4 Analyse LVD: trends soorten in vegetatieopnamen Veluwe $\quad 88$

Bijlage 5 Karakteristieke fauna van Veluwse habitattypen (excl. vogels) 94

Bijlage 6 Bodemkundige detailkarteringen van de Veluwe 98

$\begin{array}{lll}\text { Bijlage } 7 & \text { Nutriëntenvoorraden groeiplaatstypen } & 104\end{array}$

Bijlage 8 Historisch landgebruik Natura 2000 Veluwe 106 


\section{Verantwoording}

Rapport: 3036

Projectnummer: 5200046035

Wageningen Environmental Research (WENR) hecht grote waarde aan de kwaliteit van zijn eindproducten. Een review van de rapporten op wetenschappelijke kwaliteit door een referent maakt standaard onderdeel uit van ons kwaliteitsbeleid.

Akkoord Referent die het rapport heeft beoordeeld,

functie: $\quad$ senior onderzoeker

naam: A.T. Kuiters

datum: 9 september 2020

Akkoord teamleider voor de inhoud,

naam: N.A.C. Smits

datum: 28 augustus 2020 


\section{Woord vooraf}

Het Beheerplan Natura 2000 Veluwe voorziet in herstelprogramma's voor bos en heide \& stuifzand. Om de benodigde herstelmaatregelen in kaart te kunnen brengen, is in opdracht van de provincie Gelderland een beoordelingskader opgesteld voor Natura 2000-habitattypen en -leefgebieden van broedvogels. Met dit kader kunnen knelpunten en kansen voor herstel worden vastgesteld en in sessies in deelgebieden van de Veluwe bediscussieerd worden met de betreffende beheerders.

Het project werd vanuit de provincie begeleid door Jaap Ex en Adri van Kromwijk. Wij danken ook Bas Klaver, Robbert Wolf en Martin Bons voor gevoerde discussie.

Voor de vervaardiging van de Landschappelijke Bodemkaart van de Veluwe leverden Michel Riksen en Gilbert Maas GIS-bestanden.

Wij danken alle betrokkenen van de Beheerdersgroep Veluwe die speciaal voor dit project tijd hebben vrijgemaakt en ons hebben voorzien van nuttige correcties en aanvullingen, in het bijzonder Jaap Bouwman (Kroondomein Het Loo), die een lijst opstelde van karakteristieke kleine fauna.

\section{Werk in uitvoering}

In de loop van 2020 wordt het hier voor de Veluwe gepresenteerde beoordelingskader nader uitgewerkt en zo nodig aangepast voor toepassing in de gehele provincie Gelderland en in de provincies Limburg en Noord-Brabant. De in dit rapport opgenomen beoordelingsformats zullen zo mogelijk worden verbeterd en er zullen formats worden toegevoegd voor Natura 2000-habitattypen en -leefgebieden van soorten. Hierover zal afzonderlijk worden gerapporteerd. 


\section{Samenvatting}

In het Beheerplan Natura 2000 Veluwe worden herstelprogramma's aangekondigd voor bos en voor heide \& stuifzand. Het gaat voor bos om vier habitattypen en drie broedvogels en voor heide \& stuifzand om acht habitattypen en zeven broedvogels. SNL-beheertype N01.04 Zandlandschap wordt ook expliciet betrokken.

Doel van de opdracht was:

1. Het onderbouwen van streefbeelden en randvoorwaarden/vuistregels voor de omvang en het goed functioneren van betreffende habitattypen en (populaties van) soorten op landschapsschaal, gegeven de fysisch-geografische variatie van de Veluwe en

2. Het opstellen van een leidraad voor het in kaart brengen van knelpunten, kansen en maatregelen voor herstel tijdens deelgebiedssessies met terreinbeheerders.

Doel 1 is gerealiseerd door het opstellen van een beoordelingskader waarmee met vaste criteria habitattypen en leefgebieden worden beoordeeld. De criteria sluiten aan op de systematiek van Standaardgegevensformulieren. Voor habitattypen worden de volgende criteria gebruikt: Landschappelijke positie en samenhang, Oppervlaktebehoefte, Structuur, Functie en Karakteristieke soorten en vegetatietypen. Deze criteria worden gescoord als Goed, Voldoende of Onvoldoende. De beoordeling van leefgebieden is gesplitst in Geschiktheid leefgebied (met criteria Oppervlakte, Kwaliteit en Druk-factoren) en Duurzaamheid populatie (met criteria Omvang, Dichtheid, Aantalstrend en Verspreidings-trend). Deze criteria worden gescoord als Optimaal, Voldoende, Onvoldoende en Marginaal. Criteria en maatlatten (subcriteria) zijn voor alle habitattypen en leefgebieden van de opdracht uitgewerkt in zogenaamde formats (beoordelingsformulieren). Kenmerken van de beoordelingsklasse Goed vormen een referentie voor 'natuurlijke' processen en relaties met bijbehorende structuur, nodig voor duurzame instandhouding van habitattypen en populaties. Kenmerken van beoordelingsklasse Optimaal zijn ontleend aan toplocaties. Met deze formats kan voor (deelgebieden op) de Veluwe worden bepaald hoe de actuele situatie is en kan in de toekomst bijvoorbeeld na het uitvoeren van maatregelen - worden bepaald in hoeverre verbeteringen of verslechteringen zijn opgetreden in doelbereik.

De beoordelingscriteria en maatlatten voor habitattypen worden toegelicht en onderbouwd. De beoordeling van landschappelijke positie en abiotische randvoorwaarden is gekoppeld aan een nieuw vervaardigde Landschappelijke Bodemkaart van het Natura 2000-gebied Veluwe. De formats voor de beoordeling van broedvogels zijn ontleend aan eerdere rapportages over geschiktheid van leefgebied en duurzaamheid van populaties op de Veluwe.

Doel 2 is uitgewerkt als een toelichting hoe het beoordelingskader in een deelgebied kan worden toegepast en uitgewerkt tot kansen en maatregelen voor herstel, gericht op een hoger doelbereik. Hierbij wordt met name gekeken naar habitattypen en leefgebieden die in het betreffende deelgebied een groot relatief belang vertegenwoordigen binnen de Veluwe, soms ook binnen Nederland. Kansen en maatregelen, gekoppeld aan knelpunten in het beoordelingskader, worden in hoofdlijnen uitgewerkt.

De uitkomsten van de deelgebiedssessies zullen door de provincie voor de Veluwe als geheel worden afgewogen tot een passende en effectieve verzameling herstelmaatregelen voor bos en heide \& stuifzand. 


\section{$1 \quad$ Inleiding}

\subsection{Achtergrond}

In het Beheerplan Natura 2000 Veluwe heeft de provincie aangegeven hoe zij de Natura 2000-doelen voor de Veluwe gaat realiseren. Het beheerplan beschrijft het kader waarbinnen de realisatie moet plaatsvinden en de maatregelen die uitgevoerd moeten worden. Onderdeel van dit maatregelenpakket zijn maatregel M17a 'Opstellen herstelprogramma's boshabitats en boshabitatsoorten' en maatregel M18a 'Opstellen herstelprogramma's voor soorten van open habitattypen'. Provincie Gelderland geeft invulling aan beide maatregelen door twee herstelprogramma's op te stellen:

1. Herstelprogramma bos;

2. Herstelprogramma heide \& stuifzand.

Het herstelprogramma bos gaat over de realisatie van doelen voor de volgende Natura 2000habitattypen en soorten op de Veluwe:

- Oude eikenbossen (H9190)

- Beuken-eikenbossen met hulst (H9120)

- Beekbegeleidende bossen (H91E0C)

- Hoogveenbossen (H91D0)

- Wespendief (A072)

- Draaihals (A233)

- Zwarte specht (A236)

Het herstelprogramma heide \& stuifzand gaat over de realisatie van doelen voor de volgende Natura 2000-habitattypen en -soorten op de Veluwe:

- Vochtige heiden (H4010A)

- Droge heiden (H4030)

- Jeneverbesstruwelen (H5130)

- Heischrale graslanden (H6230)

- Zandverstuivingen (H2330)

- Stuifzandheiden met struikhei (H2310)

- Binnenlandse kraaiheibegroeiingen (H2320)

- Pioniervegetaties met snavelbiezen (H7150)

- Draaihals (A233)

- Boomleeuwerik (A246)

- Nachtzwaluw (A224)

- Roodborsttapuit (A276)

- Tapuit (A277)

- Grauwe klauwier (A338)

- Duinpieper (A255)

Beheertype N01.04 Zandlandschap (GEN: Grote Eenheid Natuur) wordt expliciet betrokken bij beide herstelprogramma's.

Met de herstelprogramma's wil de provincie inzicht in wat, waar en wanneer bereikt moet worden om de gebiedsdoelen te realiseren en welke maatregelen daarvoor nodig zijn. Dit vraagt om een uitwerking op deelgebiedsniveau. De resultaten op deelgebiedsniveau bij elkaar 'opgeteld', resulteren in het bereiken van de doelen uit het Aanwijzingsbesluit voor de Veluwe.

Het instrumentarium voor inrichting en beheer vormt de gereedschapskist met maatregelen uit het beheerplan Veluwe, inclusief PAS-maatregelen. Het kan zijn dat uit de gebiedsuitwerking naar voren komt dat de gereedschapskist aangevuld moet worden. 


\subsection{Doelstelling}

Doel van de opdracht is het opstellen van een kader voor de beoordeling van bos- en heide-stuifzandlandschappen op de Veluwe als onderdeel van de herstelprogramma's bos en heide \& stuifzand (zie stap 1, volgende paragraaf). Het gaat hierbij om:

- Het onderbouwen van streefbeelden en randvoorwaarden/vuistregels voor de omvang en het goed functioneren van betreffende habitattypen en (populaties van) soorten op landschapsschaal, gegeven de fysisch-geografische variatie van de Veluwe;

- Het opstellen van een leidraad voor het in kaart brengen van knelpunten, kansen en maatregelen voor herstel tijdens deelgebiedssessies met terreinbeheerders.

Het op te stellen beoordelingskader werkt vanuit streefbeelden voor een goede structuur, functie en representativiteit van habitattypen en een goede geschiktheid van leefgebieden met duurzame populaties. Hierbij dient het rapport 'Natura 2000-habitattypen in Gelderland' (Bijlsma et al., 2008) als inspiratiebron, aangevuld met nieuwe kennis en inzichten. Belangrijke bronnen zijn verder het profielendocument, de PAS-herstelstrategieën (deel II en III), het herstelprogramma voor vogelsoorten (Sierdsema et al., 2020a,b) en uitkomsten van OBN-onderzoek (Deskundigenteam Droog zandlandschap), zoals de brochures 'Stuifzanden' (2011), 'Heidelandschap in ontwikkeling' (2014) en 'Arme bossen verdienen beter' (2015), het themanummer Landschap 34(2) 'OBN-onderzoek droog zandlandschap' (2017) en over het gebruik van steenmeel (Van Diggelen et al., 2019; De Vries et al., 2019). Ook is aangesloten bij de werkwijze beoordeling structuur \& functie van habitattypen zoals door WENR/CBS gebruikt voor de Habitatrichtlijn Artikel 17-rapportage 2019 (Janssen et al., 2020).

\subsection{Werkwijze op hoofdlijnen}

De uitwerking van de herstelprogramma's vindt plaats in drie stappen. De projectopdracht betreft uitsluitend stap 1, maar voor een goed begrip van de uitwerking worden alle stappen hier kort en in samenhang besproken. Uitgangspunt is dat een Veluwe-brede afweging van maatregelen pas kan plaatsvinden als door middel van sessies met terreinbeheerders kansen voor herstel en bijbehorende maatregelen op hoofdlijnen in kaart zijn gebracht. Het gaat hierbij om twaalf deelgebieden.

\subsubsection{Stap 1. Opstellen van een beoordelingskader en een synthesedocument voor gebiedssessies}

Voor het vaststellen van de benodigde herstelmaatregelen op de Veluwe moet de ecologische toestand van habitattypen en leefgebieden worden beoordeeld. Dit zal plaatsvinden in deelgebieden (zie stap 2). Hierbij wordt gebruikgemaakt van een beoordelingskader op landschapsniveau, uitgewerkt per habitattype en leefgebied en van een synthese van knelpunten, kansen en maatregelen voor gebruik in gebiedssessies.

\section{Opstellen beoordelingskader (formats, criteria, maatlatten)}

Voor de beoordeling van habitattypen en leefgebieden in deelgebieden worden vaste ecologische criteria gebruikt die samen het beoordelingskader vormen. Voor habitattypen gaat het om de criteria 1) landschappelijke positie en samenhang, 2) oppervlaktebehoefte, 3) structuur, 4) functie en 5) karakteristieke soorten en vegetatietypen. Voor leefgebieden van vogels om 1) geschiktheid leefgebied (1a oppervlakte, 1b kwaliteit en 1c drukfactoren) en 2) duurzaamheid populatie ( $2 a$ omvang en $2 b$ trends). Per criterium worden een of meer aspecten beoordeeld met maatlatten die bepalen hoe het deelgebied scoort ten opzichte van een streefbeeld. Voor habitattypen worden bij de beoordeling naast Goed (= streefbeeld) ook de categorieën Voldoende en Onvoldoende onderscheiden en gekenmerkt. Voor leefgebieden van vogels wordt de geschiktheid van leefgebied beoordeeld als Optimaal (= streefbeeld), Voldoende, Onvoldoende of Marginaal (zie § 2.3.2 voor een toelichting) en de duurzaamheid van de populatie als Goed, Voldoende of Onvoldoende. 
Bij de onderbouwing van de streefbeelden voor habitattypen en leefgebieden dienen fysischgeografische verschillen in bodemvruchtbaarheid (mineralen, nutriënten, vochtvoorziening) van de Veluwe als uitgangspunt. Dit sluit aan op de in gebiedsanalyses gebruikelijke LESA-benadering en bij de PAS-herstelstrategieën op landschapsschaal.

\section{Opstellen synthesedocument voor gebiedssessies}

Het vaststellen van gewenste en mogelijke herstelmaatregelen in deelgebieden vindt plaats in gebiedssessies aan de hand van 1) vooraf ingevulde (gescoorde) formats van relevante habitattypen en leefgebieden en 2 ) een synthesedocument dat voor een deelgebied de processen en uitgangspunten beschrijft die hebben geleid tot de huidige natuurwaarden en dat een beknopte analyse geeft van knelpunten, kansen en maatregelen op basis van de ingevulde formats.

\subsubsection{Stap 2. Deelgebiedssessies met beheerders}

De gebiedssessie bespreekt knelpunten, kansen en maatregelen voor herstel van habitattypen en leefgebieden in het deelgebied aan de hand van het synthesedocument inclusief beoordelingsformats. Deze 'confrontatie' richt zich met name op het:

1. Bespreken van het relatieve belang van het deelgebied binnen de Veluwe en binnen Nederland;

2. Checken en zo nodig aanpassen/aanvullen van knelpunten en kansen voor herstel van habitattypen en leefgebieden waarvoor het deelgebied relatief belangrijk is; knelpunten worden ontleend aan het toegepaste beoordelingskader (formats);

3. Vaststellen van benodigde maatregelen op hoofdlijnen en aandachtspunten bij eventuele uitvoering (zie stap 3);

4. Inschatten van de bijdrage van eventuele maatregelen aan vergroting van het doelbereik voor de betreffende habitattypen en leefgebieden.

\subsubsection{Stap 3. Veluwe-brede prioritering van maatregelen}

Op grond van de tijdens de gebiedssessies aangepaste synthesedocumenten van de deelgebieden wordt een Veluwe-brede beleidsmatige afweging en prioritering gemaakt van maatregelen gericht op hoge overall ecologische effectiviteit (duurzaamheid) van vergroting van het doelbereik. Hierbij spelen ook andere overwegingen mee dan natuurkwaliteit, zoals economische, technische en maatschappelijke haalbaarheid. Per deelgebied moet vervolgens de ambitie voor herstel worden vastgesteld (wat, waar, wanneer?) en welke maatregelen hiervoor nodig zijn (hoe?), zodanig dat een goede invulling wordt gegeven aan de realisatie van de Natura 2000-doelen voor de Veluwe.

\section{$1.4 \quad$ Leeswijzer}

De onderbouwing van het beoordelingskader (formats, criteria en maatlatten) wordt toegelicht in Hoofdstuk 2. De formats zelf zijn opgenomen in Bijlagen 1 (habitattypen) en 2 (leefgebieden broedvogels). Beoordelingsformats en ondersteunend kaartmateriaal worden in zogenaamde gebiedssessies gebruikt voor het vaststellen van het doelbereik van habitattypen en vogels en het in kaart brengen van gewenste maatregelen, waarvoor een leidraad is opgenomen in Hoofdstuk 3. Aangezien de fysische geografie (geologie, geomorfologie, bodem, waterhuishouding) bepaalt welke habitattypen en leefgebieden 'natuurlijk' op de Veluwe voorkomen, is een landschappelijke bodemkaart gemaakt voor dit gebied waarin deze kenmerken zijn verwerkt. Deze kaart wordt toegelicht in Hoofdstuk 4. In Hoofdstuk 5 wordt historisch kaartmateriaal ontsloten waarmee veranderingen in landgebruik (en natuur) kunnen worden geanalyseerd, o.a. in relatie tot de landschappelijke bodemkaart. 


\section{Beoordelingskader}

\subsection{Gebruikte termen: format, criterium en maatlat}

De beoordeling van habitattypen en leefgebieden verloopt via formulieren, aangeduid als formats. De formats bestaan uit vaste ecologische criteria die beoordeeld worden met een of meer maatlatten (ook wel: deelcriteria, indicatoren). De scores zijn kwalitatief in drie (voor habitattypen en populaties) of vier (voor geschiktheid leefgebied) klassen, respectievelijk goed, voldoende, onvoldoende en optimaal, voldoende, onvoldoende, marginaal.

Voorbeeld: Met het format voor habitattype Beuken-eikenbossen is er voor het criterium Structuur een maatlat die de aanwezigheid van dik dood hout beoordeelt.

\subsection{Relatie met Natura 2000-rapportages}

\subsubsection{Criteria voor ecologische beoordeling in (deel)gebieden}

In de ecologische literatuur zijn compositie, structuur en functie breed geaccepteerde indicatoren voor de monitoring en beoordeling van biodiversiteit, veelal gebaseerd op het door Noss (1990) voorgestelde hiërarchisch raamwerk. De systematiek van de Standaardgegevensformulieren (Standard Data Forms, SDF) sluit hierop aan (Schmidt et al., 2017). Met SDF's worden voor elk Natura 2000gebied habitattypen en (leefgebieden van) VHR-soorten periodiek beoordeeld met criteria waarvan Behoudsstatus de belangrijkste is. ${ }^{1}$ In het SDF Habitattypen zijn de indicatoren compositie, structuur en functie terug te vinden onder respectievelijk Representativiteit, Behoudsstatus/Structuur en Behoudsstatus/Functie. In de Art.17-rapportage habitattypen (landelijk/biogeografisch niveau) is Structuur \& Functie een van de parameters van de staat van instandhouding. In het SDF Soorten/ Vogels worden structuur en functie niet expliciet onderscheiden, maar samengenomen onder Behoudsstatus: 'Mate van instandhouding van de elementen van de habitat die van belang zijn voor de betrokken soort'.

Hoewel voorliggend project niet als doel heeft het Standaardgegevensformulier voor de Veluwe te actualiseren, zou wel moeten worden gestreefd naar consistentie in beoordeling van de kwaliteit van habitattypen en leefgebieden: een score A (uitstekend) voor de Behoudsstatus van een habitattype is niet te rijmen met een aanzienlijk pakket herstelmaatregelen. Doelbereik is nadrukkelijk gekoppeld aan Behoudsstatus ('degree of conservation'). ${ }^{2}$ De relatie tussen de in formats gebruikte criteria en SDF-criteria is voor habitattypen en leefgebieden opgenomen in respectievelijk Tabel 2.1 en 2.2.

Criteria en maatlatten voor de beoordeling van Behoudsstatus zijn voor de Nederlandse situatie in eerste instantie uitgewerkt door Bijlsma et al. (2008) voor habitattypen in Gelderland, Janssen et al.

\footnotetext{
1 Het SDF is bedoeld "voor de beoordeling van de behoudsstatus van een habitat of soort in een bepaald gebied, terwijl de beoordelingen ex artikel 17 betrekking hebben op de staat van instandhouding over het geheel van een biogeografische regio op het grondgebied van een lidstaat. De term 'staat van instandhouding' wordt in artikel 1 , onder e) en i), van de Habitatrichtlijn omschreven met verwijzing naar de algemene situatie van een habitattype of een soort in een biogeografische regio. Die 'staat van instandhouding' wordt thans op regelmatige basis beoordeeld in het kader van de zesjaarlijkse voortgangsverslagen ex artikel 17 van de Habitatrichtlijn. De beoordeling van gebieden aan de hand van de criteria van bijlage III van de Habitatrichtlijn behelst een beoordeling van de behoudsstatus van een habitattype of soort in een specifiek gebied" (http://cdr.eionet.europa.eu/help/natura2000: 'Reference portal for Natura 2000' onder 'Standard Data Form').

2 Conservation objectives are intended to define as precisely as possible the desired state or degree of conservation to be reached in a particular site. Objectives should be set for each of the relevant habitat types and species present in that site. Often they are presented as quantitative targets, e.g., maintaining the population of a particular species at a given minimum number of individuals or improving the degree of conservation of a habitat type from category $C$ to $B$ within 10 years (https://ec.europa.eu/environment/nature/natura2000/faq_en.htm\#2-0 FAQ 15).
} 
(2014) voor SDF habitattypen, Ottburg \& Janssen (2014) en Bos-Groenendijk \& Van Swaaij (2018) voor SDF HR-soorten en Van Kleunen et al. (2014) voor SDF vogels. Aanvullend kan informatie worden ontleend aan buitenlandse beoordelingskaders zoals de 'fiches' voor bepaling van de Lokale Staat van Instandhouding van habitattypen en habitatrichtlijn- en vogelrichtlijnsoorten in Vlaanderen (Oosterlynck et al., 2019; Lommaert et al., 2020; Vermeersch et al., 2020).

Tabel 2.1 Relatie tussen criteria van het Standaardgegevensformulier (SDF) voor de beoordeling van habitattypen op gebiedsniveau en criteria in formats voor de beoordeling van habitattypen van de Veluwe.

\begin{tabular}{ll} 
Criteria SDF en beoordelingsschaal & Criteria formats \\
Behoudsstatus/Structuur & Landschappelijke positie en samenhang \\
\cline { 2 - 2 } \begin{tabular}{l} 
(A uitstekend, B goed bewaard, C passabel of gedeeltelijk aangetast) \\
\cline { 2 - 2 } $\begin{array}{l}\text { Behoudsstatus/Functie } \\
\text { (A uitstekend vooruitzicht, B goed vooruitzicht, C passabel of }\end{array}$
\end{tabular} \\
$\begin{array}{l}\text { ongunstig vooruitzicht) } \\
\text { Representativiteit }\end{array}$ & Functie (incl. drukfactoren) \\
(A uitstekend, B goed, C beduidend, D aanwezig maar weinig & Karakteristieke soorten en vegetatietypen \\
waardevol) &
\end{tabular}

Tabel 2.2 Relatie tussen criteria van het Standaardgegevensformulier (SDF) voor de beoordeling van leefgebieden van HR-soorten en vogels op gebiedsniveau en criteria in formats voor de beoordeling van leefgebieden van de Veluwe.

\begin{tabular}{ll} 
Criteria SDF en beoordelingsschaal & Criteria formats \\
Behoudsstatus/Instandhouding elementen leefgebied & Geschiktheid leefgebied/Oppervlakte \\
\cline { 2 - 2 } $\begin{array}{l}\text { (I volkomen gaaf, II goed geconserveerd, III matige conditie of } \\
\text { gedeeltelijk aangetast) }\end{array}$ & $\begin{array}{l}\text { Geschiktheid leefgebied/Kwaliteit (bodem, } \\
\text { reproductiebiotoop, foerageerbiotoop) }\end{array}$ \\
\cline { 2 - 2 } $\begin{array}{l}\text { Populatie } \\
\text { (Relatieve bijdrage van gebied aan landelijke populatie in drie }\end{array}$ & Drukfactoren \\
klassen) & Duurzaamheid populatie/Omvang \\
& Duurzaamheid populatie/Dichtheid \\
\hline
\end{tabular}

\subsubsection{Karakteristieke soorten van habitattypen}

Herstelprogramma's in Natura 2000-beheerplannen richten zich op de realisatie van doelen voor Natura 2000-habitattypen en VHR-soorten. Hoewel habitattypen (in Nederland) in hoge mate plantensociologisch zijn gedefinieerd, wordt de kwaliteit van habitattypen sterk bepaald door het functioneren als leefgebied voor een groot aantal soorten, zowel flora als fauna. Een van de parameters van de beoordeling van de landelijke staat van instandhouding van habitattypen is Structuur \& Functie inclusief typische soorten. De in Nederland gebruikte lijst van typische soorten is onvoldoende geschikt gebleken voor de beoordeling van dit aspect (Bijlsma \& Janssen, 2014) en daarom is een uitgebreidere lijst gemaakt van zogenaamde karakteristieke soorten (kader 2.1), vooralsnog alleen vaatplanten, mossen en korstmossen.

\section{Kader 2.1 Karakteristieke soorten van een habitattype}

Karakteristieke soorten van een habitattype zijn soorten:

- Met een aanzienlijke binding aan het habitattype binnen de voor het habitattype relevante fysischgeografische regio's;

- Die behoren tot taxonomische groepen die zodanig landelijk en regelmatig worden gemonitord dat korte- en langetermijntrends (10-30 jaar) kunnen worden bepaald op regionaal niveau, nu en in de toekomst. 
Deze lijst is in samenwerking met het CBS gebruikt voor de Artikel 17-rapportage van Structuur \& Functie van habitattypen in 2019 (Janssen et al., 2020) en zal op termijn worden uitgebreid met soorten uit fauna-groepen.

Trends van karakteristieke soorten worden gebruikt voor de beoordeling van criterium Functie. Het aantal karakteristieke soorten wordt gebruikt voor criterium Karakteristieke soorten en vegetatietypen. (Zie § 2.4.7 voor toelichting.)

\subsubsection{Natura 2000-gebied en deelgebieden}

De beoordeling van het Natura 2000-gebied Veluwe wordt uitgevoerd in deelgebieden. Bij het werken met deelgebieden is voor de bepaling van het doelbereik of een maatregelenpakket op gebiedsniveau nog een extra stap nodig. Bij het uitvoeren van deze stap worden de volgende ecologische overwegingen betrokken:

1. Het relatieve belang van het (deel)gebied ten opzichte van de landelijke oppervlakten en populaties van respectievelijk habitattypen en soorten. Hoe groter dit relatieve belang, hoe groter de verantwoordelijkheid om dit belang optimaal veilig te stellen over een zo groot mogelijke oppervlakte binnen het betreffende Natura 2000-gebied.

2. Het afdekken van ecologische variatie binnen het verspreidingsgebied van een habitattype of soort. Dit volgt rechtstreeks uit de definitie van gunstige referentiewaarde voor verspreidingsgebied (FRR, Favourable Reference Range) voor zowel habitattypen als soorten. Dit betekent dat het betreffende (deel)gebied moet worden beoordeeld als onderdeel van de aanwezige ecologische variatie binnen het historische verspreidingsgebied. Zo wordt habitattype Droge heiden vaak geassocieerd met arme zandgronden, omdat vrijwel alle droge heide op vruchtbaardere gronden (lemige gronden en leemgronden) is ontgonnen. Hierdoor zijn heischrale vegetaties en soorten-rijkere typen van droge heide verdwenen en is de historische variatie (en biodiversiteit) van het heidelandschap uit beeld geraakt. De vraag is dan welke bijdrage een (deel)gebied kan leveren aan het herstel van een gunstig verspreidingsgebied. Voor soorten is het dus onvoldoende om één duurzame populatie (groter dan een Minimum Viable Population, MVP) in een gebied te hebben als daarmee de ecologische variatie niet is afgedekt. ${ }^{3}$

3. Duurzaamheid van populaties van VHR-soorten en van karakteristieke soorten van habitattypen. Deze overweging vraagt om een inschatting van de omvang en isolatie/samenhang van populaties op gebiedsniveau (en eventueel zelfs buiten Natura 2000) en de rol van deelgebieden daarbij. Hierbij kan gebruik worden gemaakt van vuistregels voor MVP's, sleutelgebieden en netwerkafstanden (zie § 2.5.1). Maatregelen zijn gericht op het versterken, verbinden of vergroten van populaties.

4. Refugia van weinig mobiele soorten. Karakteristieke soorten waarvan het leefgebied al zo ver is afgenomen dat ze alleen nog lokaal of verspreid en geïsoleerd voorkomen, verdienen speciale aandacht, zeker als bekend is dat spontane hervestiging na lokaal uitsterven uitgesloten lijkt. Voor dergelijke kwetsbare karakteristieke soorten zijn specifieke maatregelen nodig, gericht op versterking en uitbreiding van populaties.

Aangezien per deelgebied het relatieve belang van habitattypen en leefgebieden alsook criteria voor landschappelijke samenhang en oppervlaktebehoefte en populatiegrootte worden beoordeeld, kan een beoordeling van de Veluwe als geheel plaatsvinden aan de hand van gesignaleerde kansen in deelgebieden.

\footnotetext{
3 Deze constatering wordt expliciet verwoord in de Article 17 reporting Guidelines 2013-2018: http://cdr.eionet.europa.eu/help/habitats_art17, met name onder 'Stepwise process for setting the favourable reference values for species', afkomstig uit EC Service Contract, gerapporteerd in Bijlsma et al. (2019a).
} 


\subsection{Beoordelingsklassen, referenties en scores}

Voor de beoordeling van habitattypen en soorten worden verschillende formats gebruikt, omdat voor habitattypen het actuele voorkomen wordt beoordeeld, terwijl voor soorten geschiktheid van leefgebied (ongeacht het voorkomen de soort) en duurzaamheid van het huidige voorkomen van de soort afzonderlijk worden gescoord.

\subsubsection{Beoordelingsklassen habitattypen}

De criteria voor de beoordeling van habitattypen worden gescoord als Goed, Voldoende of Onvoldoende (Tabel 2.3), waarbij Goed als referentie dient. De klasse Voldoende houdt wat betreft kenmerken meestal het midden tussen Goed en Onvoldoende.

De beoordeling vindt plaats per maatlat (per criterium). Kansen voor herstel kunnen een of meer maatlatten betreffen, gericht op vergroting van doelbereik, bijvoorbeeld van Onvoldoende naar Voldoende. In het algemeen zal het niet haalbaar zijn alle criteria/maatlatten in een goede toestand te krijgen, maar zeker voor habitattypen en leefgebieden met een groot relatief belang moet de lat hoog worden gelegd, gezien de ambitie van Natura 2000 om landelijk tot een gunstige staat van instandhouding te komen.

Tabel 2.3 Model format voor beoordeling habitattypen.

\begin{tabular}{l} 
Criterium \\
Landschappelijke positie en samenhang \\
\hline Oppervlaktebehoefte \\
\hline Structuur \\
\hline Functie \\
\hline Karakteristieke soorten en vegetatietypen \\
\hline
\end{tabular}

\subsubsection{Beoordelingsklassen leefgebieden}

De criteria voor de beoordeling van leefgebieden worden gescoord als Optimaal, Voldoende, Onvoldoende of Marginaal (Tabel 2.4), waarbij Optimaal als referentie dient. De klasse Marginaal betreft inherent ongunstig of irreversibel verslechterd leefgebied dat praktisch gesproken niet in aanmerking komt voor herstel. Marginaal leefgebied kan tijdelijk of in zeer lage dichtheid door een soort worden benut, maar draagt niet bij aan de populatie-omvang. De klasse Onvoldoende daarentegen betreft ongunstig leefgebied dat met maatregelen kan worden hersteld en dan belangrijk kan bijdragen aan de populatie-omvang. De klasse Voldoende houdt wat betreft kenmerken meestal het midden tussen Optimaal en Onvoldoende.

Tabel 2.4 Model format voor beoordeling leefgebieden.

\begin{tabular}{|c|c|c|c|c|}
\hline A Criterium Geschiktheid leefgebied & Optimaal & Voldoende & Onvoldoende & Marginaal \\
\hline \multicolumn{5}{|l|}{ Oppervlakte } \\
\hline \multicolumn{5}{|l|}{$\begin{array}{l}\text { Kwaliteit (bodem, reproductiebiotoop, } \\
\text { foerageerbiotoop) }\end{array}$} \\
\hline \multicolumn{5}{|l|}{ Drukfactoren } \\
\hline \multicolumn{5}{|l|}{ Omvang } \\
\hline \multicolumn{5}{|l|}{ Dichtheid } \\
\hline \multicolumn{5}{|l|}{ Aantalstrend } \\
\hline Verspreidingstrend & & & & \\
\hline
\end{tabular}




\subsubsection{Referenties: Goed en Optimaal}

In principe correspondeert de aanduiding Goed (voor habitattypen) met 'natuurlijke' geomorfologische, hydrologische en populatie-biologische processen met bijbehorende structuur, nodig voor duurzame instandhouding. Dit geldt ook voor halfnatuurlijke habitattypen (graslanden, heiden). 'Goed' impliceert de aanwezigheid van de voor een gebied karakteristieke abiotische en biotische waarden en processen in de zin van 'natuurlijke kenmerken' van een gebied (integrity of the site), zoals bedoeld in Artikel 6.3 van de Habitatrichtlijn. Het concept van 'meer natuurlijkheid' in Natura 2000-gebieden is uitgewerkt en toegepast door Bijlsma et al. (2017) en betreft nadrukkelijk niet alleen Grote Eenheden Natuur (zie Kader 2.2).

Kenmerken van Optimale geschiktheid van leefgebied en duurzaamheid van populaties worden ontleend aan toplocaties voor de betreffende soort.

Relevante historische referenties zijn afhankelijk van habitattype en leefgebied en veelal expliciet gekozen bij het opstellen van (landelijke) gunstige referentiewaarden (Favourable Reference Values, FRV's). Naast deze 'reference-based'-benadering bij het opstellen van FRV's kan met name voor soorten gekozen worden voor een 'model-based'-benadering gebaseerd op kennis van Minimum Viable Populations (MVP's). ${ }^{4}$ Zie Bijlsma et al. $(2019 a)^{5}$ voor nadere discussie en richtlijnen voor het gebruik van historische referenties en model-based methoden voor bepaling van FRV's.

Kader 2.2 'Meer natuurlijkheid' (Uit: Bijlsma et al., 2017)

"Een grotere natuurlijkheid wordt vaak gekoppeld aan minder menselijke invloed. Het begrip natuurlijkheid is hiermee negatief gedefinieerd en onderwerp van blijvende discussie over hoe die invloed, direct en indirect, moet worden bepaald en gewogen. Wij stellen een positief geformuleerde en praktische definitie van 'meer natuurlijkheid' of 'natuurlijker' voor, die uitgaat van het belang van meer uitwijkmogelijkheden voor natuur, gekoppeld aan een grotere risicospreiding. Een gebied beschouwen wij als natuurlijker dan het was naarmate:

- De werkzaamheid van systeemkarakteristieke landschapsvormende en hydrologische processen is vergroot;

- Een grotere geomorfologisch-bodemkundige variatie in landschappelijke samenhang beschikbaar is gekomen voor leefgebieden en vegetatieontwikkeling;

- Er meer uitwijkmogelijkheden zijn gerealiseerd: bereikbaar en (tijdelijk) geschikt leefgebied wanneer omstandigheden veranderen;

- Er meer uitwisseling en interacties optreden binnen en tussen karakteristieke soorten."

\subsubsection{Beoordeling: ruimtelijke schaal en wijze van scoren}

\section{Ruimtelijke schaal van habitatclusters}

De beoordeling van habitattypen vindt plaats via 'habitatclusters' waarin naast kwalificerend habitattype ook biotopen zijn opgenomen van ontwikkelingsstadia en andere verwante vegetatietypen. Het criterium oppervlaktebehoefte wordt vervolgens beoordeeld op grond van de omvang en ruimtelijke samenhang (connectiviteit) van de habitatclusters, gegeven dispersieafstanden van voor het habitat-type karakteristieke fauna. Aldus kunnen verschillende, in ecologisch opzicht geïsoleerde land-schappelijke eenheden worden onderscheiden en beoordeeld (zie § 2.4.2 voor nadere toelichting).

De analyse van karakteristieke soorten flora (vaatplanten, mossen, korstmossen) van habitattypen sluit aan op de Art.17-rapportage (Janssen et al., 2020) die is uitgevoerd op km-hokniveau, dat wil zeggen voor km-hokken met habitattype. Het gebruik van grenswaarden voor het aantal

\footnotetext{
4 FRV's zijn beschikbaar voor Nederlandse habitattypen (Bijlsma et al., 2014) en HR-soorten (Ottburg \& Van Swaaij, 2014). De Vogelrichtlijn werkt niet met FRV's maar dit concept is wel uitgewerkt voor vogels in Bijlsma et al. (2019a) met voorbeelden in Bijlsma et al. (2019b).

5 Verwerkt in Article 17 reporting Guidelines 2013-2018: http://cdr.eionet.europa.eu/help/habitats_art17
} 
karakteristieke soorten is dus alleen geldig op het schaalniveau van km-hokken (zie § 2.4.7 voor nadere toelichting).

Het schaalniveau van beoordeling van leefgebieden wordt bepaald door de mate van samenhang van leefgebied aan de hand van leefgebiedkaarten (Sierdsema et al., 2016). ${ }^{6}$ Voor broedvogels van de Veluwe zijn ook geschiktheidskaarten beschikbaar (Sierdsema et al., 2020a, b).

\section{Wijze van scoren}

Per maatlat worden voor het betreffende habitatcluster of leefgebied de oppervlakte-aandelen van beoordelingsklassen geschat op 10\% nauwkeurig, bijvoorbeeld 30\% Goed, 50\% Voldoende en $20 \%$ Onvoldoende. Dit voorkomt een krampachtige toekenning van Goed, Voldoende of Onvoldoende. Eventueel kan Onbekend als extra categorie worden gescoord (met een bepaald \%) als benodigde informatie ontbreekt.

\subsubsection{Databronnen voor beoordeling}

\section{Habitattypen}

In de formats voor habitattypen is per maatlat aangegeven welke databronnen van belang zijn bij de beoordeling. De in de formats gebruikte aanduidingen voor bronnen staan in Tabel 2.5 uitgelegd.

Tabel 2.5 Aanduidingen van informatiebronnen voor het beoordelen van maatlatten zoals opgenomen in de formats voor habitattypen.

\begin{tabular}{ll} 
Bron & Omschrijving \\
AHN & Actueel Hoogtebestand Nederland \\
\hline HYDRO & Hydrologische data/peilbuisgegevens \\
\hline LBK & Landschappelijke Bodemkaart Veluwe (zie Hoofdstuk 4) en bodemkaart 1:50.0000 \\
\hline LUFO & Recente luchtfoto's of reeks van luchtfoto's uit meerdere jaren (LUFO-reeks) \\
\hline NDEP & Grootschalige depositiekaarten RIVM \\
\hline NDFF & NDFF-verspreidingsgegevens over een langere periode (vanaf 2000) \\
\hline N2BP & Natura 2000-beheerplan, PAS-gebiedsanalyse \\
\hline SNL & Soortkarteringen in kader van SNL of ander inventarisatieproject \\
\hline STRUCT & Structuurkarteringen (voor bossen) zoals SYHI \\
\hline TBO & Informatie via terreinbeheerder \\
\hline TMK & Topographische Militaire Kaart (ca. 1850) of Kadastrale kaart 1832 (HISGIS) \\
\hline TOPO & Digitale topografische kaart (TOP10NL, TOP25raster) \\
\hline VEG & Vegetatiekaart, vegetatieopnamen en habitatkaart \\
\hline VELD & Aanvullend veldwerk \\
\hline
\end{tabular}

\footnotetext{
${ }^{6}$ Zie ook https://www.bij12.nl/onderwerpen/natuur-en-landschap/monitoring-en-natuurinformatie/leefgebiedkaartennatura-2000-en/
} 


\section{Leefgebieden}

Informatiebronnen voor de beoordeling van maatlatten in de formats van leefgebieden zijn niet opgenomen in de formats zelf, maar aangegeven in Tabel 2.6.

Tabel 2.6 Informatiebronnen voor het beoordelen van maatlatten in formats voor leefgebieden. Voor gebruikte afkortingen: zie Tabel 2.5.

\begin{tabular}{ll} 
A Geschiktheid leefgebied & $\begin{array}{l}\text { Bronnen } \\
\text { Oppervlakte }\end{array}$ \\
$\begin{array}{l}\text { Geschiktheidskaart (indien beschikbaar); Landschapskaart heide met de omvang van } \\
\text { heidevelden/stuifzanden; TOPO }\end{array}$ \\
\hline Kwaliteit/bodem & LBK; bodemkaart \\
\hline Kwaliteit/broedbiotoop & VEG; TMK; LUFO; NDEP; Bosstatistiek; Veldkennis \\
\hline Kwaliteit/foerageerbiotoop & VEG; TMK; LUFO; NDEP; Bosstatistiek; Veldkennis \\
\hline Drukfactoren & Kaart recreatiedichtheid WUR; Afstand tot parkeerplaatsen, recreatiecentra en \\
& $\begin{array}{l}\text { dorpen/steden; Informatie over begrazingsdruk; Militair gebruik; Geluidskaart } \\
\text { snelwegen/N-wegen }\end{array}$ \\
\hline B Duurzaamheid populatie & Broedvogelkarteringen; NDFF; Gemodelleerde verspreidingskaarten \\
\hline Omvang & Broedvogelkarteringen; NDFF; Gemodelleerde verspreidingskaarten \\
\hline Dichtheid & Broedvogelkarteringen (aangevuld met losse meldingen) \\
\hline Aantalstrend & Broedvogelkarteringen; NDFF; Vogelatlassen \\
\hline Verspreidingstrend &
\end{tabular}

\subsection{Beoordelingscriteria habitattypen}

\subsubsection{Landschappelijke positie en samenhang}

Aan Natura 2000-beheerplannen liggen gebiedsanalyses ten grondslag die de huidige natuurwaarden plaatsen in landschapsecologische samenhang en in historisch perspectief. Deze vorm van analyse is in Nederland geformaliseerd als LESA (LandschapsEcologische SysteemAnalyse: Van der Molen et al., 2011). Een LESA brengt in kaart welke ecosystemen en leefgebieden (Noss 1990: compositie) karakteristiek zijn voor een bepaald landschap en welke landschapsecologische condities en processen (Noss 1990: structuur en functie) belangrijk zijn voor de duurzame instandhouding en/of ontwikkeling van deze biodiversiteit. Tegelijkertijd komen hiermee drukfactoren en bedreigingen in beeld.

Inzicht in de landschapsecologische voorwaarden voor behoud van compositie, structuur en functie van ecosystemen en leefgebieden heeft ertoe geleid dat er naast herstelstrategieën op habitattype- en leefgebiedniveau (PAS-herstelstrategieën deel II) ook aandacht is gekomen voor de landschapsecologische inbedding van beheer- en herstelmaatregelen (PAS-herstelstrategieën deel III). ${ }^{7}$ Dit deel III is uitgewerkt voor verschillende landschappen waarvan Droog zandlandschap en Nat zandland-schap voor de Veluwe de belangrijkste zijn.

In de beoordelingsformats voor habitattypen zijn voor het criterium Landschappelijke positie en samenhang de volgende relaties gebruikt:

- Relatie met fysisch-geografische series van de Landschappelijke Bodemkaart (moedermateriaal, geomorfologie; zie Hoofdstuk 4): H2330 (stuifzandcel), H4030 (rijke en arme vorm) en H6230 (idem), H9120, H9190;

- Relatie met historisch landgebruik, historische landschapselementen of -zones: H4030 (rijke en arme vorm: leemheide nabij ontginningen vs. zandheide), H9120, H9190 (oude bosgroeiplaatsen), H9120 (boswallen, oude infrastructuur; zie Bijlsma et al., 2009);

- Relatie met geomorfologische gradiënten en ruimtelijke heterogeniteit van moedermateriaal: $\mathrm{H} 2310$, H4010A, H4030, H5130, H7150 en H91D0;

- Relatie met gezoneerde hydrologische condities: H4010A, H7150, H91D0, H91E0C.

\footnotetext{
7 https://www.natura2000.nl/meer-informatie/herstelstrategieen
} 
De meeste van de op de Veluwe voorkomende habitattypen waarvoor beoordelingsformats zijn opgesteld, komen ook voor in andere fysisch-geografische regio's onder vergelijkbare abiotische condities (leemgronden, lemige en leemarme zandgronden, stuifzandgronden e.d.), met name in de oude delen van het rivierengebied (terrassen, rivierduinen) en in het heuvelland (terrassen). Bij het opstellen van de formats is hiermee impliciet rekening gehouden zonder vooralsnog de betreffende fysisch-geografische context altijd te benoemen. Het is mogelijk dat een format van een habitattype of leefgebied moet worden bijgesteld om het ook geschikt te maken voor toepassing in andere fysischgeografische regio's.

Ruimtelijke samenhang in de vorm van uitwisseling tussen (deel)populaties van karakteristieke soorten is voor habitattypen uitgewerkt onder criterium Oppervlaktebehoefte.

\subsubsection{Oppervlaktebehoefte}

Voldoende oppervlakte leefgebied en connectiviteit van populaties zijn cruciaal voor het duurzaam voorkomen van habitattypen en soorten. Kleine en geïsoleerd rakende leefgebieden hebben een groot risico op verdwijnen, zowel door verslechtering als verstorende gebeurtenissen. Om de oppervlaktebehoefte van habitattypen te kunnen inschatten, worden twee routes gevolgd: voor korte vegetaties worden referentieoppervlakten gebaseerd op de eisen van karakteristieke soorten. Voor bossen en boslandschappen wordt de nagestreefde oppervlakte afgeleid van de benodigde oppervlakte voor voldoende structuurdynamiek (aandelen van ontwikkelingsstadia). Aangezien het leefgebied van praktisch geen enkele soort is beperkt tot slechts één habitattype moet bij het gebruik van oppervlakte-eisen van soorten worden geselecteerd op soorten met een sterke binding aan habitattypen ('karakteristieke soorten'; zie Kader 2.1) en worden vastgelegd welke biotopen worden betrokken bij de oppervlakteanalyse ('habitatcluster' naar Oosterlynck et al., 2019). Om een sterke relatie tussen habitattype en habitatcluster te garanderen, worden alleen biotopen betrokken die als direct ontwikkelingsstadium van het betreffende habitattype gelden en/of in mozaïek voorkomen binnen eenzelfde landschappelijk-bodemkundige eenheid. Uitgaande van een habitatkaart (en onderliggende vegetatiekaart) en landschappelijke bodemkaart (bodem, geomorfologie) kunnen habitatclusters door luchtfoto-interpretatie worden begrensd op grond van structuurkenmerken. Voor sommige habitattypen kan ook gebruik worden gemaakt van de beheertypenkaart.

Het vaststellen van habitatclusters gebeurt op een vlotte (efficiënte) wijze, via een expertbeoordeling, gebruikmakend van de genoemde gegevens in dit rapport en de formats. Het is niet noodzakelijk om zeer precieze berekeningen van oppervlakten en afstanden in GIS uit te voeren. Het is slechts een middel om te komen tot doelen op gebiedsniveau en verder doelbereik te monitoren. De begrenzing van habitatclusters is ook relevant voor de beoordeling van de criteria Structuur en Functie.

De beoordeling van de oppervlaktebehoefte van korte vegetaties en bossen wordt hieronder nader toegelicht.

\section{Oppervlaktebehoefte korte vegetaties en struwelen}

Voor halfnatuurlijke, korte vegetaties kunnen oppervlaktebehoeftes worden gekoppeld aan de leefgebieden van karakteristieke faunasoorten en hun (meta-)populatiedynamiek en dispersieafstanden. Hoewel er voor habitattypen nog geen lijst van karakteristieke faunasoorten is vastgesteld, zijn vertegenwoordigers van relevante faunagroepen wel goed in beeld (Bijlage 5). Voor de beoordeling van de oppervlaktebehoefte van habitattypen gebruiken wij het concept 'sleutelgebied', ontleend aan Pouwels et al. (2002b; zie ook Pouwels et al. 2008):

Sleutelgebied $=$ groot leefgebied dat een stabiliserende werking heeft binnen een ecologisch netwerk van populaties; soorten kunnen duurzaam voorkomen in sleutelgebieden als er immigratie is van minimaal één individu per generatie; sleutelgebieden liggen in een ecologisch netwerk.

Wij koppelen de oppervlaktebehoefte van habitattypen (via habitatclusters) aan de grootte van sleutelgebieden van karakteristieke fauna, in Pouwels et al. (2002b, Tabel 2.1 en B3.2) voor zes 
oppervlaktecategorieën ( $<1.5$ ha tot $>75 \mathrm{~km}^{2}$ ). Het merendeel van de kleine fauna (vlinders, muizen, reptielen) en broedvogels wordt toegekend aan de oppervlakte-categorieën $<0.5 \mathrm{ha}, 0.5 \mathrm{ha}-0.5 \mathrm{~km}{ }^{2}$, 0.5-3 km² en 3-7.5 km². In genoemde tabellen wordt oppervlaktebehoefte uitgezet tegen netwerkafstand:

Netwerkafstand = afstand waarbinnen twee populaties behoren tot eenzelfde ecologisch netwerk; wanneer de afstand tussen een geïsoleerd leefgebied en het dichtstbijzijnde leefgebied groter is dan de netwerkafstand, zal het leefgebied een eigen ecologisch netwerk vormen.

Netwerkafstanden kunnen worden gebruikt om de connectiviteit van habitatclusters te beoordelen. Geïsoleerde habitatclusters worden in principe afzonderlijk beoordeeld.

Voorbeeld: voor H2330 (Zandverstuivingen) wordt het criterium oppervlaktebehoefte als Onvoldoende beoordeeld als het betreffende landschap alleen habitatclusters bevat die kleiner zijn dan het sleutelgebied van karakteristieke vlinders $\left(<0.5 \mathrm{~km}^{2}\right)$ met netwerkafstand $1 \mathrm{~km}$. De beoordeling is Goed als aan de criteria voor Voldoende is voldaan en een of meer habitatclusters als sleutelgebied van de nachtzwaluw fungeren $\left(>3 \mathrm{~km}^{2}\right.$ ) met netwerkafstand $25 \mathrm{~km}$. Hiertoe kan het nodig zijn ook leefgebied buiten het Natura 2000-(deel)gebied in beschouwing te nemen. Door het betrekken van netwerkafstanden wordt dus duidelijk welke ruimtelijke samenhang van habitatclusters relevant is: alle stuifzandcellen binnen de netwerkafstand van $25 \mathrm{~km}$.

\section{Oppervlaktebehoefte bossen ${ }^{8}$}

De oppervlaktebehoefte voor het natuurlijk functioneren van bossen op het schaalniveau van het bosmozaïek ('gap dynamics') kan worden ontleend aan het concept van minimum structuurareaal (MSA; Bücking, 2003; Parviainen, 2005) gebaseerd op het algemenere concept van 'minimum dynamic area' (Poiani et al., 2000). Om ook verstoringen op grotere schaal ruimte te geven ('stand dynamics'; Angelstam \& Kuuluvainen, 2005; Hahn et al., 2007), moet het MSA worden vergroot met ten minste een factor vijf (Parviainen, 2005). Deze minimum oppervlaktebehoefte (MOB) is nog steeds een structuurareaal zonder eisen aan soortensamenstelling (Busing \& White, 1993). Voor bostypen die sterk gezoneerd voorkomen (zoals beekbegeleidende typen, beekdal-, hoogveen- of venranden) of afhankelijk zijn van lokaal optredende condities (zoals bronbossen) is een MOB niet van toepassing (Tabel 2.7).

Tabel 2.7 Minimum structuurareaal (MSA, ha) en minimum oppervlaktebehoefte (MOB, ha) van Veluwse bostypen. Bostypen en MSA naar Koop \& Van der Werf (1995).

\begin{tabular}{llll} 
Habitattype & Bostype & MSA & MOB \\
H9120 & Wintereiken-Beukenbos & 40 & 200 \\
\hline H9120 & Gierstgras-Beukenbos & 25 & 125 \\
\hline H9190 & Berken-Zomereikenbos & 50 & 250 \\
\hline H91D0 & Berken-Elzenbroek/Berkenbroek & $25 / 30$ & n.v.t. \\
\hline H91E0C & Gewoon Elzenbroek & 20 & n.v.t. \\
\hline H91E0C & Elzenbronbos & 10 & n.v.t.
\end{tabular}

\subsubsection{Structuur en functie: decor versus spel en spelers}

Uitgaande van compositie, structuur en functie als hoofdindicatoren voor de beoordeling en monitoring van biodiversiteit (zie $\S 2.2 .1$ ), vertegenwoordigen structuur en functie samen de door maatregelen te beïnvloeden kwaliteit van een ecosysteem. ${ }^{9}$ De structuur beschrijft de toestand (het 'patroon') van condities en componenten van een habitattype/leefgebied, met name de aanwezigheid en rangschikking van terreinvormen, vegetatietypen, gelaagdheid en samenhang. Ook de abiotische toestand, zoals vocht- en nutriëntenbeschikbaarheid, valt onder structuur. Structuur omvat dus zowel min of meer

8 Ontleend aan Bijlsma et al. (2019a §3.3.2).

9 De tekst van deze paragraaf is grotendeels ontleend aan notitie Bijlsma \& Sanders in een WOt-project over 'Duurzaamheid beheer habitattypen' voor Natuurverkenning 2020 (PBL). 
onveranderlijke (onafhankelijke) componenten, zoals diversiteit van moedermateriaal en bodem, als elementen die door inrichtings- en beheermaatregelen kunnen worden beïnvloed, bijvoorbeeld door natuurontwikkeling, boskap en maaien. De functie beschrijft de werking van alle processen die nodig zijn voor het behoud, het herstel en de eventuele ontwikkeling van een goede compositie en structuur inclusief abiotische toestand van het ecosysteem (habitattype, leefgebied), alsook de werking van drukfactoren. Zowel natuurlijke dynamiek (getijdewerking, grondwaterregime, inundaties, verstuiving) als beheermaatregelen (maaien, begrazen e.d.) vallen onder functie, alsook biotische processen en interacties zoals bestuiving, predatie, kolonisatie en (gewenste of ongewenste) successie.

Structuur (toestand) en functie (processen) zijn niet onafhankelijk, omdat structuurelementen het resultaat zijn van processen (successie, beheer, interacties vegetatie-fauna). Een goede structuur behoeft onderhoud door goed functionerende processen (zoals aanvoer van grondwater, verstuiving en beheer) en stelt eisen aan het terugdringen van drukfactoren (zoals hoge $\mathrm{N}$-depositie en overmatige recreatie). Bij de invulling van de formats voor een deelgebied zal een goede beoordeling van de functie dan ook vaak samengaan met een goede beoordeling van de structuur die het resultaat is van die functie.

Expliciet onderscheid tussen structuur en functie wordt steeds belangrijker in de communicatie over de kwaliteit van natuur omdat steeds vaker natuur er nog mooi uitziet, maar niet meer functioneert als leefgebied voor karakteristieke soorten. Denk aan 'paarse heide' zonder kleine fauna, bos met veel dood hout maar met negatieve trend van holenbroeders en uitsterfschuld ('extinction debt') ${ }^{10}$ in bloemrijke graslanden. Structuur behelst het 'decor', terwijl functie blijkt uit het 'spel' en de 'spelers'. Dit onderscheid ligt ook aan de basis van een aangepaste wijze van beoordeling van Structuur \& Functie voor de Art.17-rapportage in 2019 (Janssen et al., 2020).

Een goede structuur en functie worden gekenmerkt door een gewenste toestand en de daarbij behorende gewenste processen (en ongewenste drukfactoren). Tabel 2.8 geeft algemene richtlijnen voor de beoordeling van structuur en functie.

Tabel 2.8 Algemene richtlijnen voor de beoordeling van structuur en functie van habitattypen.

\begin{tabular}{|c|c|c|}
\hline Criterium & GOED & ONVOLDOENDE \\
\hline Functie & $\begin{array}{l}\text { - vereiste abiotische processen (voor onderhoud van } \\
\text { compositie en structuur) optimaal werkzaam } \\
\text { - ongewenste drukfactoren afwezig } \\
\text { - gewenste biotische processen optimaal werkzaam } \\
\text { (verjonging, voortplanting, uitwisseling, hervestiging, } \\
\text { plant-dier-interacties) } \\
\text { - het leefgebied van karakteristieke soorten blijft op } \\
\text { orde blijkens overwegend stabiele of positieve trends } \\
\text { in verspreiding en/of populatieomvang }\end{array}$ & $\begin{array}{l}\text { - het leefgebied van steeds meer karakteristieke } \\
\text { soorten verslechtert, resulterend in overwegend } \\
\text { negatieve trends, inteelt, uitsterfschuld (extinction } \\
\text { debt) en/of lokaal uitsterven (NB negatieve trends } \\
\text { signaleren een verslechterende functie van het } \\
\text { leefgebied door een of meer oorzaken) }\end{array}$ \\
\hline
\end{tabular}

\footnotetext{
10 "Geïsoleerde of kleine populaties die geen migratie- of uitwisselingsmogelijkheden meer hebben, hebben op langere termijn een verhoogde kans op uitsterven. Voor langlevende, sedentaire organismen kan het verdwijnen van dergelijke populaties meerdere decennia tot zelfs eeuwen duren waardoor de verspreiding van deze soorten gedurende geruime tijd niet in evenwicht is met de landschapsveranderingen die hebben plaatsgevonden. Dit fenomeen wordt extinctieschuld (Extinction debt) genoemd" (Hermy \& Bijlsma, 2010).
} 


\subsubsection{Structur en functie op de Veluwe}

De Veluwe wijkt af van andere natuurgebieden op de hogere zandgronden door de aanwezigheid van populaties van edelherten en wilde zwijnen. Deze soorten hebben een grote invloed op de samenstelling, structuur en functie van alle habitattypen en leefgebieden. De Veluwse habitattypen bos en heide zien er dus anders uit en maken een andere ontwikkeling door dan elders in ons land. Dit vertaalt zich onder andere in significant minder verjonging van (loof)boom- en struiksoorten en een tragere successie, een opener bosstructuur, gewijzigde houtige groeivormen (meerstammigheid, strubben), andere relatieve soortensamenstelling (weinig lijsterbes, bramen, kamperfoelie), hoger aandeel semipermanente open ruimtes in bossen (bosweide) en een heterogeen vegetatiemozaïek van droge heide met continue verjonging van struikhei. Zowel de edelherten en zwijnen als hun interacties met het landschap zijn onderdeel van de 'natuurlijke kenmerken' van de Veluwe (zoals bedoeld in $\S 2.3 .3$ ), wat niet wegneemt dat een hoge wildstand als ongewenste drukfactor kan fungeren (zie $\S 2.4 .6)$.

\subsubsection{Maatlatten voor de beoordeling van structuur}

Het criterium Structuur kan worden beoordeeld met maatlatten voor verschillende structuurcomponenten. Deze paragraaf bespreekt maatlatten gebruikt in de beoordelingsformats.

Abiotische structuurkenmerken, zoals nutriëntenvoorraden en zuurbuffercapaciteit, zijn van groot belang voor het functioneren van habitattypen en leefgebieden (o.a. voedselkwaliteit, zie § 2.6), maar door gebrek aan data praktisch niet direct te beoordelen. In Bijlage 7 is voor een aantal groeiplaatstypen informatie bijeengebracht.

Let wel: Voor de beoordeling van de structuur van een habitattype moeten dezelfde omvang en begrenzing van het betreffende habitatcluster worden gebruikt als voor de beoordeling van het criterium Oppervlaktebehoefte (zie § 2.3.4).

\section{Bossen}

Belangrijke structuurkenmerken van bossen ontstaan door langdurige spontane ontwikkeling of onder langdurig extensief beheer. De bekendste zijn:

- Bosmozaïek met verjongingseenheden en aftakelingsfasen. Hiertegenover staat bos met uniforme structuur en/of afgeknotte leeftijdsverdeling als gevolg van bosbouwkundig gebruik. Terwijl natuurlijke verjonging in principe optreedt in alle bossen, ook uitgesproken productiebossen/ plantagebossen, komt vlaksgewijze natuurlijke sterfte door ouderdom alleen (en nog steeds schaars!) voor in bossen met een langdurig spontane ontwikkeling.

- Hoeveelheid dood hout. Op grond van de review in Müller \& Bütler (2010) van dood hout in Europese bossen is Tabel 2.9 opgesteld. De drempelwaarden (in $\mathrm{m}^{3} /$ ha) gelden voor hardhoutbossen, ongeacht bostypen. Deze waarden zijn ook gebruikt in de laatste Art.17-rapportage (Janssen et al., 2020).

Tabel 2.9 Drempelwaarden voor de hoeveelheid staand en liggend dood hout bij de beoordeling van de structuur van bossen.

\begin{tabular}{ll} 
Structuur & Hoeveelheid dood hout $\left(\mathrm{m}^{3} / \mathrm{ha}\right)$ \\
gunstig & $\geq 30$ \\
\hline matig ongunstig & $15-30$ \\
\hline zeer ongunstig & $<15$ \\
\hline
\end{tabular}

- Aanwezigheid van (zeer) dikke bomen (>80 cm dbh). Deze maatlat wordt alleen gebruikt voor H9120 met een hoog aandeel beuk. Europese 'old growth'-beukenbossen hebben een mediane dichtheid van 11 zeer dikke bomen en kwartielwaarden van 5 en 16 bomen per ha (Vandekerkhove, 2019 Chapter 3). 
- Aanwezigheid van eikenclusters, ontstaan door spontane vestiging en ontwikkeling onder hoge graasdruk in heideachtige vegetaties (Den Ouden et al., 2009). Deze maatlat wordt alleen gebruikt voor $\mathrm{H} 9190$.

- Aanwezigheid van dikke humusprofielen, in droge bossen met name Holtxeromormoders (met $\mathrm{Hh} \geq 2 \mathrm{~cm}$ en $\mathrm{F} 2+\mathrm{H} \geq 5 \mathrm{~cm}$ dik; Van Delft et al., 2006).

In lijn met deze natuurlijkheidskenmerken wordt de structuur van bossen met een hakhoutachtergrond lager gescoord dan van bossen die langdurig als opgaand bos zijn beheerd. Afhankelijk van de gemeente geeft de kadastrale kaart 1832 hierover vaak informatie. Zie Goutbeek (2015) voor discussie over de biodiversiteit van hakhoutbossen op de hogere zandgronden.

In de formats voor bossen worden geen maatlatten gebruikt voor bosstructuur en gelaagdheid, omdat beide kenmerken sterk variëren in de loop van cyclische bosdynamiek en voortgaande successie en als gevolg van wilddruk. Beide kenmerken worden impliciet meegenomen bij de beoordeling van het bosmozaïek.

\section{Korte vegetaties en struwelen}

Belangrijke structuurkenmerken van korte vegetaties en struwelen betreffen het ruimtelijke patroon van ontwikkelingsfasen en vegetatietypen en van dominantie en leeftijdsverdeling van aspectbepalende soorten:

- Aandelen in natuurlijk vegetatiemozaïek van pioniersstadia (H2310, H4010A) of oude, langdurig niet-beheerde delen (H4030: bosbesheide, oude heide op dik ectorganisch humusprofiel) ${ }^{11}$, droge/hogere en vochtige/lagere delen (H4010A), open vegetaties met minerale bodem versus geheel gesloten grazige of door dwergstruiken gedomineerde vegetaties (H2310, H2330, H5130)

- Vegetatiemozaïeken met andere habitattypen (H2320, H5130)

- Leeftijdsverdeling van aspectbepalende soorten (H4030: struikheicyclus; H5130: jeneverbes)

- Min of meer aaneengesloten (vlakdekkende) versus lintvormige voorkomens (H6230)

- Mate van voorkomen van aspectbepalende karakteristieke soorten (veenmossen in H4010A, H91D0)

- Mate van voorkomen van karakteristieke structuurelementen, zoals jeneverbes en eikenclusters in heide- en stuifzandlandschap.

Heterogene patronen worden veelal beschouwd als natuurlijker (score Goed) als deze het gevolg zijn van spontane differentiatie door heterogeniteit in bodemvruchtbaarheid, vochtbeschikbaarheid, reliëf, begrazing e.d. Dit geldt ook voor halfnatuurlijke habitattypen: denk aan graslanden met intact t.o.v. geëgaliseerd reliëf, mozaïeken als gevolg van heterogene abiotische condities en natuurlijke verjonging/veroudering t.o.v. mozaïeken door plaggen of maaien.

\subsubsection{Maatlatten voor de beoordeling van functie}

Het criterium Functie kan worden beoordeeld aan de hand van zogenaamde maatlatten voor verschillende processen en drukfactoren. Deze paragraaf bespreekt de in de boordelingsformats gebruikte maatlatten.

Let wel: Voor de beoordeling van de functie van een habitattype moeten dezelfde omvang en begrenzing van het betreffende habitatcluster worden gebruikt als voor de beoordeling van het criterium Oppervlaktebehoefte (zie § 2.3.4).

De beoordeling van functiekenmerken vindt plaats met maatlatten voor:

1. Eisen aan de continuïteit van gewenste processen voor onderhoud van een goede compositie en structuur;

2. Trends van soorten;

3. Eisen aan drukfactoren.

\footnotetext{
${ }^{11}$ Net als bij de bossen geldt ook voor heiden en graslanden dat oude stadia vaak erg waardevol zijn. Zo zijn allerlei kenmerkende paddenstoelen van heischraal grasland beperkt tot zogenaamd 'oud grasland'. Een langdurig, stabiel, extensief beheer (of gebruik) leidt in veel halfnatuurlijke ecosystemen tot een hoge biodiversiteit.
} 


\section{Continuïteit van gewenste processen}

- Jaarrond extensieve begrazing van het bos- en heidelandschap door grote herbivoren, o.a. resulterend in min of meer permanent open ruimtes, continuïteit van pionier-milieus, patroonvorming in grazige vegetaties en heiden en ruimtelijke differentiatie in bossen; deze functie is alleen 'goed' als begrazing plaatsvindt op landschapsschaal en over gradiënten in bodemvruchtbaarheid (incl. voormalige bouwlanden, leemgronden e.d.).

- Continuïteit in natuurlijke verjonging en aftakeling van definiërende, structuurbepalende soorten (bossen, H4030).

- Extensieve bodemroering door dassen en wilde zwijnen (H6230).

- Continuïteit van verteringsstadia van dik dood hout en van ontwortelingskluiten- en kuilen die functioneren als belangrijke microhabitats in langdurig niet-beheerde bossen.

Niet altijd is bekend in hoeverre continuïteit van natuurlijke verjonging een 'goed' functiekenmerk is van habitattypen, bijvoorbeeld voor Jeneverbesstruwelen en Oude eikenbossen. Er zijn ook aanwijzingen dat substantiële verjonging het gevolg kan zijn van incidenteel optredende gebeurtenissen ('windows') die gunstig zijn voor kieming en vestiging, bijvoorbeeld in relatie tot kiembed, graasdruk, lichtbeschikbaarheid en/of weerscondities. Verjonging vindt dan veelal niet plaats op de locatie van het habitattype zelf, maar in de naaste omgeving en niet continu, maar incidenteel onder toevallige, gunstige omstandigheden.

Een algemener probleem met ecologische maatlatten voor 'goed' functionerende boshabitats op de droge zandgronden is dat de structuur en ontwikkeling van deze bossen nog steeds sterk volgen uit aanleg en beheer. Dit geldt niet alleen voor de voormalige hakhoutbossen, maar ook voor de huidige opgaande beukenbossen. Zowel de landschappelijke positie als de ontwikkeling van structuurkenmerken (zoals groeivorm) en de 'natuurlijke' dynamiek (zoals eikensterfte) is lastig te beoordelen, omdat natuurlijke(r) referenties ontbreken in NW-Europa. De door eik gedomineerde bossen zijn hier mogelijk een artefact van aanleg en beheer en het is twijfelachtig of behoud van dergelijke bossen op en buiten de Veluwe überhaupt mogelijk is via spontane ontwikkeling.

\section{Trends van karakteristieke soorten}

- Trends van soorten met een binding van leefgebied aan het habitattype (karakteristieke soorten); in het geval van overwegend negatieve trends is weliswaar niet duidelijk welke condities (structuur) of processen (functie) beperkend zijn, maar wel dat er iets mis is; nadere analyse is dan gewenst. Deze analyse is voor karakteristieke soorten vaatplanten, (korst)mossen en paddenstoelen (lijsten in Bijlage 3) op km-hokniveau uitgevoerd voor de laatste drie rapportageperioden (1999-2004, 20052010, 2011-2016) als onderdeel van de Art.17-rapportage van de parameter Structuur \& Functie in 2019 (zie Janssen et al., 2020). In Bijlage 4 zijn resultaten opgenomen van een aanvullende analyse van trends van karakteristieke soorten in vegetatieopnamen in de Landelijke Vegetatiedatabank voor droge bossen, droge heiden en stuifzanden van de Veluwe. Bijlage 5 geeft een voorlopige, nieuw opgestelde lijst van karakteristieke fauna van Veluwse habitattypen. Al deze informatie ${ }^{12}$ alsook aanvullende analyses van NDFF-gegevens vormen een belangrijke onderbouwing van de beoordeling van functie, ook als het voorlopige, in statistisch opzicht (nog) onbevredigende analyses betreft (zoals in Bijlage 4).

- Trends in optreden van aspectbepalende inheemse soorten, zoals pijpenstrootje (H4010A, H4030) en bramen (op soortniveau) en framboos (H91D0, H91E0C). Een langjarige, positieve trend van dergelijke soorten in de betreffende habitattypen kan wijzen op verdroging, verzuring en/of vermesting of is per definitie ongewenst, zoals een sterke toename van beuk in Oude eikenbossen (H9190).

\section{Eisen aan drukfactoren:}

- $\mathrm{N}$-depositie ten opzichte van de betreffende kritische depositiewaarden (KDW's). Dit aspect scoort altijd Goed als de N-depositie lager is dan de KDW en Onvoldoende als de N-depositie hoger is dan de KDW.

- Invasieve exoten in boom-, struik- en kruidlaag van bossen (zoals Amerikaanse eik, Amerikaanse vogelkers, Amerikaans krentenboompje, Japanse lork, reuzenbalsemien), in struwelen (zoals

\footnotetext{
${ }^{12}$ De lijsten van karakteristieke soorten in Bijlage 3 en 5 kunnen ook worden gebruikt om na te gaan voor welke van de karakteristieke soorten het (deel)gebied van groot relatief belang is. Zie Hoofdstuk 3.
} 
dijkviltbraam, dwergmispels) en in korte vegetaties (zoals late en Canadese guldenroede, grijs kronkelsteeltje).

- Ernstige verstoring door recreatie of andere menselijke activiteiten.

Hoewel zeker rekening moet worden gehouden met hoge dichtheden van edelherten en zwijnen als ongewenste drukfactor, ontbreekt het aan expliciet Veluwse 'natuurlijke( $r)^{\prime}$ ' referentiebeelden voor samenstelling, structuur en functie van habitattypen die in deze opzichten significant kunnen verschillen van minder begraasde of onbegraasde habitats (zie ook § 2.4.4). Langjarige trends van karakteristieke soorten kunnen worden gebruikt voor het signaleren van ongewenste ontwikkelingen. Nadere analyse moet vervolgens uitwijzen in hoeverre wilddruk hierbij een sleutelrol speelt. Zie Van der Weide (2019) en Den Ouden et al. (2020) voor verdere discussie.

\subsubsection{Karakteristieke soorten en vegetatietypen}

Het criterium Karakteristieke soorten en vegetatietypen beoordeelt de rijkdom aan karakteristieke soorten en vegetatietypen van het betreffende habitattype in een (deel)gebied en is gekoppeld aan de SDF-rapportage van Representativiteit (vergelijk Tabel 2.1). In tegenstelling tot kenmerken van Structuur en Functie kan Representativiteit niet direct worden beïnvloed door herstel- en beheermaatregelen: er zullen normaal gesproken geen soorten of vegetatietypen worden toegevoegd aan een habitattype anders dan door het (opnieuw) beschikbaar maken, verbeteren of verbinden van geschikt leefgebied, gevolgd door het afwachten van eventuele spontane (her)vestiging. Alleen door herintroductie kunnen soorten daadwerkelijk worden toegevoegd.

Een groot aantal karakteristieke soorten wijst op een hoge kwaliteit van het leefgebied. Een klein aantal soorten wordt weliswaar beoordeeld als Onvoldoende, maar hoeft niet te wijzen op een slechte kwaliteit: de afwezigheid van soorten kan het gevolg zijn van historische barrières (isolatie) voor vestiging. Het criterium geeft in historisch perspectief inzicht in het relatieve belang van het habitattype: is of was dit gebied een toplocatie of was altijd al sprake van een beperkte diversiteit van soorten en vegetatietypen? Dit inzicht zal mede de ambitie bepalen voor herstel.

\section{Maatlat karakteristieke soorten}

Het relatieve belang van een (deel)gebied voor karakteristieke soorten wordt bepaald volgens een samen met het CBS opgestelde methode die gebruikt is voor de Art.17-rapportage 2019 van Structuur \& Functie. De methode beoordeelt het aantal karakteristieke soorten van een habitattype in kmhokken met dat habitattype ten opzichte van de landelijke lijst (voor Veluwse habitattypen: zie Bijlage 3). De grenswaarden voor een goede, voldoende of onvoldoende representativiteit gelden alleen voor vaatplanten, mossen, korstmossen en paddenstoelen, maar uitbreiding met fauna is voorzien.

De redeneerlijn en werkwijze bij de beoordeling van karakteristieke soorten zijn uitgeschreven in het achtergronddocument bij de HR-rapportage habitattypen (Janssen et al., 2020). De grenswaarden voor beoordeling zijn afgeleid uit de verdeling van soortenrijkdom zoals bepaald in een landelijke analyse van het cumulatieve aantal soorten in (voldoende onderzochte) km-hokken met kwalificerend habitattype voor de periode 1999-2016.

De maatlat wordt beoordeeld als Goed als het aantal karakteristieke soorten groter of gelijk is aan het mediane aantal in Tabel 2.10 en Onvoldoende als het aantal kleiner is dan het eerste kwartiel. 
Tabel 2.10 Totaal aantal karakteristieke soorten (vaatplanten, mossen, korstmossen en paddenstoelen) voor de selectie van Veluwse habitattypen, met drempelwaarden voor de beoordeling van het criterium Karakteristieke soorten.

\begin{tabular}{|c|c|c|c|}
\hline HCode & Totaal & Mediaan & Kwartiel1 \\
\hline $\mathrm{H} 2310$ & 23 & 13 & 9 \\
\hline H2330 & 25 & 13 & 7 \\
\hline $\mathrm{H} 4030$ & 22 & 7 & 5 \\
\hline H5130 & 9 & nvt & nvt \\
\hline H7150 & 11 & 8 & 7 \\
\hline H9120 & 48 & 14 & 11 \\
\hline H9190 & 26 & 6 & 4 \\
\hline H91D0 & 19 & 4 & 3 \\
\hline
\end{tabular}

\section{Overige maatlatten}

- Voor het op relatieve rijke bodems voorkomende habitattype 9120 (op oude bosgroeiplaatsen) wordt het aantal zogenaamde 'oudbosplanten' als extra maatlat gebruikt. Zie o.a. Bijlsma (2002), Wulf (2003) en Cornelis et al. (2009) voor indicatorsoorten.

- Voor habitattype 4010A wordt het aandeel karakteristieke veenmossen als extra maatlat gebruikt (alle, ten minste één of geen).

- Voor de droge boshabitats 9120 en 9190 weegt het voorkomen van kwalificerende mantel- en zoomvegetaties (conform profielendocument) mee bij de beoordeling.

\subsection{Beoordelingscriteria leefgebieden}

\subsubsection{Ruimtelijke condities en populatiekenmerken (literatuuroverzicht)}

Voor soorten en leefgebieden kan worden aangesloten bij onderzoek dat is uitgevoerd naar ruimtelijke condities voor VHR-soorten (Pouwels et al., 2002a, 2002b, 2007), namelijk de oppervlaktebehoefte van een sleutelgebied en de netwerkafstand waarbinnen deelpopulaties functioneel samenhangen (Tabel 2.11; zie § 2.4.2 voor definities). Deze kentallen zijn bedoeld om de grootteorde van ruimtelijke eisen van soorten te kunnen inschatten.

Tabel 2.11 Ruimtelijke kenmerken en eisen van vogelsoorten. Netwerkafstand en oppervlaktebehoefte voor een sleutelgebied volgens Pouwels et al. (2002b, Tabel B3.2).

\begin{tabular}{llll} 
Nederlandse naam & Wetenschappelijke naam & Netwerkafistand $(\mathrm{km})$ & Oppervlakte sleutelgebied $(\mathrm{km} 2)$ \\
boomleeuwerik & Lullula arborea & 25 & 0.5 \\
\hline draaihals & Jynx torquilla & 50 & 200 \\
\hline duinpieper & Anthus campestris & 25 & 30 \\
\hline grauwe klauwier & Lanius collurio & 10 & 7.5 \\
\hline nachtzwaluw & Caprimulgus europaeus & 25 & 3 \\
\hline roodborsttapuit & Saxicola rubicola & 10 & 7.5 \\
\hline tapuit & Oenanthe oenanthe & 25 & 30 \\
\hline wespendief & Pernis apivorus & 25 & 30 \\
\hline zwarte specht & Dryocopus martius & 50 & 7.5 \\
\hline
\end{tabular}

\subsubsection{Toelichting bij beoordelingsformats vogels}

De ecologische informatie over de vogelsoorten in de beoordelingsformats is afkomstig uit twee rapporten: Factsheets van broedvogels in de Natura 2000-gebieden van Gelderland (Sierdsema et al., 2008) en Soortenherstel-programma beheerplan Natura 2000 Veluwe: Ecologisch profiel en analyse 
knelpunten vogelsoorten (Nijssen et al., 2019). Het rapport van 2019 bevat voor zeven van de negen soorten een update van de informatie uit het rapport van 2008. Roodborsttapuit en Grauwe Klauwier komen alleen in het 2008-rapport aan de orde.

De informatie over het voorkomen en over dichtheden is grotendeels afgeleid van de informatie verzameld voor het rapport 'Natuurbeheer- en zoneringsmaatregelen voor zeven aangewezen vogelsoorten in Natura 2000-gebied Veluwe: Bouwstenen Soortenherstel Beheerplan Natura 2000 Veluwe' (Sierdsema et al., 2020a, b).

Voor de beoordeling van afzonderlijke leefgebieden is de dichtheid het relevantst; populatieomvang betreft in feite de gehele populatie (die landelijk of zelfs groter kan zijn).

\subsection{Bodemkwaliteit en voedselkwaliteit voor de fauna}

De afgelopen decennia is gebleken dat de bodemkwaliteit (basenverzadiging, P-beschikbaarheid, mineralenbeschikbaarheid, verwering) en de voedselkwaliteit voor de fauna zowel in bossen als korte vegetaties sterk verslechtert op de hogere zandgronden, wat o.a. leidt tot bodemdegradatie en een nutriëntenonbalans (hoge beschikbaarheid van stikstof, lage beschikbaarheid van basische kationen, fosfor) die doorwerkt in de voedselketen (zie o.a. Landschap 34(2) 2018: themanummer OBNonderzoek droog zandlandschap). Deze verslechtering is het gevolg van doorgaande hoge $\mathrm{N}$-depositie en verzuring en van historisch landgebruik (roofbouw door plaggen en hakhoutcultuur) en historische zuurlast. Dat het droog zandlandschap in dit opzicht hard wordt geraakt, is het gevolg van het feit dat natuur hier is teruggedrongen tot de minst productieve delen, veelal leemarme zandgronden waaronder een groot areaal stuifzandgronden. De relatief productieve delen zijn ontgonnen tot landbouwgrond of bebost met relatief veeleisend naaldhout (met name Douglasspar).

Door Siepel et al. (2018) worden twee routes voor herstel bepleit: 1) op landschapsschaal door het toevoegen van (voormalige) landbouwgronden aan het heidelandschap, waardoor beperkende voedingsstoffen weer beschikbaar komen en 2) door herstel van de mineralenvoorraad door toevoeging van mineralen, met name op degraderende bodems. De eerste route komt in voorliggend beoordelingskader expliciet aan de orde via het criterium Landschappelijke positie en samenhang. De tweede route betreft met name steenmeeltoediening. Als experimentele maatregel vereist dit vooronderzoek naar de mate waarin de betreffende bodems kunstmatig zijn verzuurd (Weijters et al., 2018; Van Diggelen et al., 2019; De Vries et al., 2019). Een kennislacune hierbij is het ontbreken van referentiewaarden voor een 'goede' bodemkwaliteit gegeven de grote variatie in geologie en textuur (en dus mineralogie) van bodems van de droge hogere zandgronden en gevolgen van natuurlijke podzolisatie en humusprofielontwikkeling (voor oude loofbossen: zie Bijlsma et al., 2020).

De betreffende abiotische structuurkenmerken, zoals nutriëntenvoorraden en zuurbuffercapaciteit, zijn door gebrek aan data praktisch niet direct te beoordelen. In Bijlage 7 is voor een aantal groeiplaatstypen informatie bijeengebracht.

\subsection{Grote eenheden natur in het zandlandschap}

Op een deel van de Veluwe wordt de beheerstrategie 'Grote eenheden natuur' (GEN) toegepast (SNLbeheertype N01.04 Zandlandschap). In 2019 zijn voor het 'nagenoeg-natuurlijk landschap' van Veluwezoom/Deelerwoud toetsbare doelen opgesteld om te bepalen of het beheer succesvol is of niet, met name gericht op eventuele aanpassing van het faunabeheer (Van der Weide 2019). Uitgangspunt is dat zo veel mogelijk ruimte wordt gegeven aan natuurlijke ontwikkeling (een 'natuurlijker' landschap). Tegelijkertijd wordt ingezet op behoud en liefst uitbreiding van kwetsbare karakteristieke natuurwaarden. Er is dus geen sprake van dogmatisch niets-doen-beheer (zie ook Schmidt \& Duinhoven, 2016). De beoordeling van toetsbare doelen wordt vervolgens ontleend aan monitoring van o.a.:

- Hoefdiersoorten (edelhert, damhert, ree, wild zwijn, Schotse hooglanders, IJslandse paarden: aantallen, geslacht, leeftijd); 
- Kwetsbare natuurwaarden, met name soorten met geringe mobiliteit waarvoor de Veluwe(zoom) een groot relatief belang heeft (dagvlinders, sprinkhanen, reptielen), maar bijvoorbeeld ook nectarplanten en verjonging van zomer- en wintereik;

- Natuurlijke processen en natuurlijk gedrag (ruimtelijke patronen van successie en verjonging, micro-habitats zoals wissels, zandbaden, wroetplaatsen en mest, humusprofielontwikkeling).

Grote eenheden natuur op de Veluwe vormen een regionale referentie voor natuurlijke(r) ontwikkeling van het bos- en heidelandschap en zijn daarom onmisbaar als leerschool. Dit kan alleen als er sprake is van structurele monitoring en rapportage zoals beoogd op Veluwezoom/Deelerwoud, gekoppeld aan eventuele ingrepen in het geval kwetsbare natuurwaarden te veel onder druk komen te staan.

De criteria in de beoordelingsformats voor habitattypen hebben - met uitzondering van criterium Karakteristieke soorten - veelal een min of meer 'natuurlijke' referentie voor landschappelijke positie en samenhang, structuur en zeker ook functie en dus met een grote rol voor continuïteit van natuurlijke processen, gradiënten, begrazing e.d. (zie § 2.3.3 en Kader 2.2). Deze formats zijn ook van toepassing op grote eenheden natuur. De vertaling van het beoordelingskader naar eventuele maatregelen zou zich in eerste instantie moeten richten op behoud en vergroting (robuust maken) van de ruimtelijke samenhang van habitattypen en leefgebieden met een groot relatief belang voor de Veluwe of Nederland. Aanvullend kan worden ingezet op behoud en herstel van kwetsbare karakteristieke waarden.

\subsection{Potentieel habitattype en leefgebied}

Zoekgebieden voor uitbreiding van heide (H2310, H4010A, H4030), stuifzand (H2330) en heischrale vegetaties (H6230) zijn voor de Veluwe gedetailleerd uitgewerkt door Koomen \& Maas (2009). In de beoordelingsformats van habitattypen is niet expliciet aangegeven aan welke kenmerken zoekgebieden voor uitbreiding ('potentieel habitattype') moeten voldoen. Deze kenmerken zijn in alle gevallen logisch af te leiden uit kenmerken van de referenties voor Landschappelijke positie, Oppervlaktebehoefte, Structuur, Functie en Karakteristieke soorten. Welk criterium hierbij een doorslaggevende rol speelt, hangt sterk af van de knelpunten in het betreffende deelgebied en dus van de uitgangssituatie. Het is praktisch niet mogelijk om in algemene zin te anticiperen op zeer verschillende uitgangssituaties, temeer omdat de formats in principe ook geldig zijn in andere Natura 2000-gebieden. Daarom is ervan afgezien om 'potentieel habitattype' expliciet te omschrijven.

Voor vogels is voor de criteria Kwaliteit broed- en foerageerbiotoop expliciet aangegeven met welke kenmerken en knelpunten rekening moet worden gehouden bij uitbreiding/herstel van leefgebied (potentieel leefgebied). 


\section{Toepassen van beoordelingskader in deelgebieden (gebiedssessies)}

Het in Hoofdstuk 2 uitgewerkte beoordelingskader is bedoeld om voor alle deelgebieden van de Veluwe na te gaan waar zich kansen voordoen om het doelbereik van de Veluwe als Natura 2000gebied duurzaam te vergroten als uitwerking van de herstelprogramma's voor bossen en heide- en stuifzandgebieden (zie $\S 1.3$ voor de werkwijze op hoofdlijnen). Hiertoe wordt voor elk deelgebied een sessie georganiseerd met terreinbeheerders, met als doel een gemeenschappelijk beeld te vormen van knelpunten en van concrete kansen en maatregelen.

Input voor deze gebiedssessies zijn:

1. Het vooraf ingevulde beoordelingskader: de formats van relevante habitattypen en leefgebieden met scores per criterium, zo nodig uitgesplitst naar habitatclusters of geïsoleerde delen van leefgebieden (zie § 2.4.2 voor nadere toelichting over het begrenzen van habitatclusters).

- Elke maatlat wordt afzonderlijk beoordeeld. Een maatlat kan bestaan uit meerdere vereisten (gescheiden door 'en') of uit meerdere alternatieven (gescheiden door 'of'). Er wordt geen eindoordeel (totaalscore) bepaald, omdat zowel vergroting van doelbereik als van maatregelen zich zal richten op een of meer criteria die in het betreffende deelgebied het relevantst zijn (zie 2.).

- Zo nodig kunnen per maatlat oppervlakteaandelen van beoordelingsklassen worden aangegeven met $10 \%$ nauwkeurigheid, bijvoorbeeld $20 \%$ goed, $80 \%$ voldoende (zie ook § 2.3.4).

- Bij de habitattypen wordt voor de beoordeling van de structuur en functie dezelfde omvang en begrenzing van clusters aangehouden als voor de beoordeling van het criterium

Oppervlaktebehoefte.

2. Een synthesedocument, waarin zijn opgenomen:

a. Uitleg van het (deel)gebied: begrenzing; fysische geografie in relatie tot het voorkomen van habitattypen en leefgebieden (landschapsecologische logica); verspreiding en zo mogelijk trends van belangrijke karakteristieke soorten van habitattypen; begrenzing van habitat-clusters.

b. Bespreking van het relatieve belang van het deelgebied binnen de Veluwe en Nederland (en eventueel zelfs Europees) voor habitattypen, karakteristieke soorten van habitattypen en VHRsoorten.

c. Tabel met knelpunten, kansen en maatregelen (op hoofdlijnen) van relevante habitatclusters en leefgebieden, gericht op het vergroten van doelbereik van criteria, zoals gescoord volgens het beoordelingskader. Hierbij ligt de nadruk op kansen die het relatieve belang van het deelgebied aanzienlijk versterken of vergroten.

d. De onder 1. genoemde, ingevulde beoordelingsformats voor habitattypen en leefgebieden van het (deel)gebied.

De gebiedssessie bespreekt knelpunten, kansen en maatregelen voor herstel van habitattypen en leefgebieden in het deelgebied aan de hand van het synthesedocument inclusief beoordelingsformats. Deze 'confrontatie' van huidig en gewenst doelbereik richt zich met name op het:

- Bespreken van het relatieve belang van het deelgebied;

- Toelichten van de habitatclusters en beoordeelde leefgebieden;

- Checken en zo nodig aanpassen/aanvullen van knelpunten en kansen voor herstel van habitattypen en leefgebieden waarvoor het deelgebied relatief belangrijk is; knelpunten worden ontleend aan het toegepaste beoordelingskader (ingevulde formats);

- Prioriteren van kansen voor herstel;

- Vaststellen van benodigde maatregelen op hoofdlijnen en aandachtspunten bij eventuele uitvoering;

- Inschatten van de bijdrage van eventuele maatregelen aan vergroting van het doelbereik van de betreffende habitattypen en leefgebieden.

Naar aanleiding van de gebiedssessie wordt het synthesedocument aangepast met een:

- Samenvatting van mogelijkheden voor het realiseren van een hoger doelbereik voor relevante habitattypen en leefgebieden, inclusief onderbouwing van verwachte vergroting van doelbereik;

- Voorlopige maatregelenkaart(en) met beschrijving op hoofdlijnen. 


\section{$4 \quad$ Landschappelijke bodemkaart van de Veluwe}

\subsection{Doel en werkwijze}

De in dit hoofdstuk beschreven landschappelijke bodemkaart (LBK) dient als abiotisch raamwerk voor referentiebeelden van habitattypen en leefgebieden en voor zoekgebieden voor herstel. In de beoordelingsformats wordt daarnaar verwezen. Ook biedt de LBK inzicht in hoe een deelgebied zich abiotisch verhoudt tot andere delen van de Veluwe. Dit is van belang om te kunnen bepalen hoe belangrijk een deelgebied binnen de Veluwe is voor bepaalde habitattypen en leefgebieden. De kaart bestaat uit fysisch-geografische eenheden (FG-eenheden) die ecologisch zijn geïnterpreteerd naar abiotische condities. ${ }^{13}$ De landschappelijke bodemkaart is gebaseerd op de landschapsecologische indeling van de Landschapsleutel (Kemmers et al., 2011) en latere aanpassingen daarop (Van Delft et al., 2015, https://klimaatvalleienveluwe.nl/atlas/). Het betreft een hiërarchische indeling met vier niveaus: fysisch-geografische regio's (FGR's), FG-secties, FG-series en FG-typen. Hier beperken wij ons tot de eerste drie niveaus. De eenheden zijn afgeleid van een combinatie van geomorfologische en bodemkundige kenmerken die samen de landschapsecologische positie bepalen. Hiervoor zijn de kaarten gebruikt van het BRO-Loket (https://www.broloket.nl/ondergrondmodellen). De legenda van de geomorfologische kaart (Maas et al., 2019) staat op https://legendageomorfologie.wur.nl/. Voor de bodemkaart verwijzen wij naar Ten Cate et al. (1995).

In $\S 4.2$ is een beknopt overzicht opgenomen van de toekenning van de combinaties van geomorfologie en bodem tot fysisch-geografische series voor FGR Hogere zandgronden, met name gericht op de Veluwe. In Figuur 4.1 is deze kaart samengevat op het niveau van FG-secties. Het Natura 2000-gebied Veluwe ligt vrijwel geheel binnen de fysisch-geografische regio 'Hogere zandgronden' (Hz). Aan de randen in het zuiden en oosten zijn kleine oppervlakten die tot het 'Rivierengebied' (Ri) gerekend worden. Voor de habitattypen in de herstelprogramma's waar dit onderzoek op gericht is, zijn deze niet relevant. Aanvullend is in extra kaartlagen extra informatie opgenomen die deels gebruikt is bij het afleiden van de FG-eenheden (randwallen en sprengkoppen) en gebruikt kan worden bij de interpretatie van de kaart (randwallen, stuifzandcellen en sprengkoppen).

De hier gepresenteerde kaart van FG-series van de Veluwe is afgeleid van de landelijke bestanden met referentieschaal 1:50.000. Op deze kaartschaal zijn ecologisch relevante verschillen op lokaal niveau, en met name de variatie in stuifzandgronden en de variatie in textuur van gestuwde afzettingen niet goed weer te geven. Daarom moet op lokaal niveau waar mogelijk gebruikgemaakt worden van detailkarteringen. Van de geomorfologische kaart zijn geen detailkarteringen beschikbaar, van de bodemkaart in een aantal deelgebieden wel. Aanwijzingen bij het interpreteren van de detailbodemkaarten zijn opgenomen in Bijlage 6.

\footnotetext{
${ }^{13}$ De kaart is beschikbaar als shape, tif of pdf via Bas van Delft (WENR, bas.vandelft@wur.nl).
} 


\subsection{Indeling van FG-regio Hogere zandgronden (focus Veluwe)}

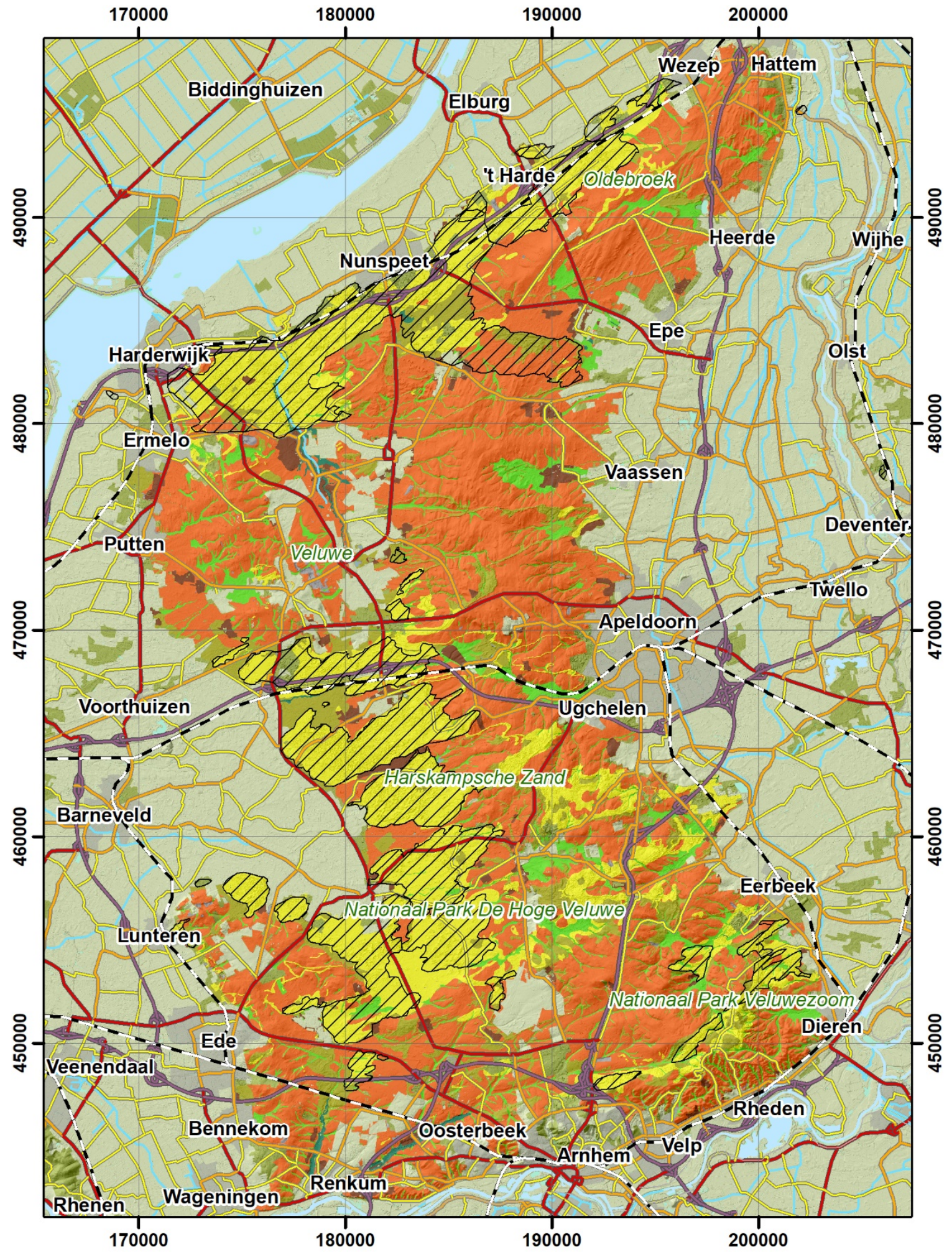

\section{Legenda}

\section{FG-secties}

HzG Glaciale gebieden HzS Stuifzandgebieden
HzD Dekzandgebieden

$\mathrm{HzB}$ Beekdalen HzBD Droogdalen
$\mathrm{HzO}$ Oude bouwlanden

NB Niet beoordeeld

$\nabla / \triangle$ Stuifzandcellen

Figuur 4.1 Landschappelijke bodemkaart voor N2000-gebied Veluwe op het niveau van fysischgeografische secties. De ligging van stuifzandcellen (zie § 4.2.2) is met een arcering aangegeven. 
Binnen de Hogere zandgronden $(\mathrm{Hz})$ onderscheidt de Landschapsleutel zes fysisch-geografische secties (Tabel 4.1), waarvan er vijf voorkomen binnen het Natura 2000-gebied Veluwe; Hoogvenen komen hier niet voor. De droogdalen (HzBD) die in de Landschapsleutel als FG-serie binnen de Beekdalen ( $\mathrm{HzB}$ ) zijn opgenomen, zijn hier apart weergegeven vanwege het belang op de Veluwe. De verbreiding is weergegeven in Figuur 4.1. De FG-secties zijn weer onderverdeeld in een aantal FGseries. De legenda van de voor de Veluwe relevante series staat in Figuur 4.2. In totaal betreft het 23 voor de Veluwe relevante FG-series. Hieronder geven wij een korte beschrijving van de FG-series voor zover deze voorkomen binnen Natura 2000-gebied Veluwe.

Tabel 4.1 Fysisch-geografische secties binnen FG-regio Hogere zandgronden met hun oppervlakte binnen Natura 2000-gebied Veluwe.

\begin{tabular}{lll} 
FG sectie & Omschrijving & Oppervlakte (ha) \\
$\mathrm{HzG}$ & Glaciale gebieden & 46030 \\
\hline $\mathrm{HzS}$ & Stuifzandgebieden & 22619 \\
\hline $\mathrm{HzD}$ & Dekzandgebieden & 8633 \\
\hline $\mathrm{HzH}$ & Hoogvenen & 0 \\
\hline $\mathrm{HzB}$ & Beekdalen & 509 \\
\hline $\mathrm{HzO}$ & Droogdalen & 7695 \\
\hline
\end{tabular}

\section{Legenda}

HzG Glaciale gebieden

HzGSI Lemige stuwwallen

Hzi. HzSa Leemarme stuwwallen

$\because \mathrm{HzGS}$ Stuwwallen

HzGPI Lemige puinwaaiers

Hz:.: HzPa Leemarme puinwaaiers

HzS Stuifzandgebieden

HzSDF Landduinen, Forten en Overstoven laagten

HzSDFd Landduinen, Forten en Overstoven laagten, actief

HzSF Forten en Overstoven laagten

HzSL Uitgestoven laagten

\ל HzSLd Uitgestoven laagten, actief

HzSX Stuifzandcomplexen

\section{HzD Dekzandgebieden}

HzDA Leemarme droge dekzandgebieden

HzDL Lemige dekzandgebieden en dekzand op leem

HzDV Vochtige dekzandlaagten

HzDG Grondwater gevoede vennen

\section{HzB Beekdalen}

HzBN Natte en verdroogde beekdalen

HzBD Droogdalen

HzBB Brongebieden

HzBV Benedenlopen en lemige beekvlakten

\section{HzO Oude bouwlanden}

三 $\mathrm{HzOZ}$ Zwarte eerdgronden

$\equiv \equiv$ HzOB Bruine eerdgronden

NB

NB Niet beoordeeld

- Sprengkop

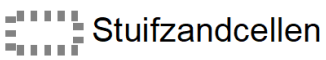

Randwallen

Figuur 4.2 Legenda van de Landschappelijke bodemkaart van Natura 2000-gebied Veluwe. 


\subsubsection{HzG Glaciale gebieden}

Binnen de FG-sectie glaciale gebieden (HzG) onderscheiden we stuwwallen (HzGS Figuur 4.3) en puinwaaiers (HzGP Figuur 4.4), waarbij de eerste groep gevormd is door opstuwing van oudere (vooral fluviatiele) afzettingen door het landijs en de tweede groep door verplaatsing van materiaal door ijs- en sneeuwsmeltwater. In de stuwwallen is de oorspronkelijke gelaagdheid van de opgestuwde afzettingen vaak nog behouden gebleven, zij het dat deze 'scheefgesteld' is, waardoor aan maaiveld of in de ondergrond een grote variatie in textuur (grof en fijn zand, meer of minder lemig, leem, grind) voor kan komen. Aan de loefzijde (oostkant) van de Veluwe, bij de Veluwezoom, is op de stuwwallen plaatselijk ook löss afgezet (bodemeenheid Ld5), waardoor de bovengrond uit leem bestaat. In de puinwaaiers is dat veel minder het geval, omdat door de smeltwaterstroom een sortering heeft plaatsgevonden waarbij het fijnere materiaal vaak verder weg is afgezet en de puinwaaier zelf vaak grofzandig en grindhoudend is.

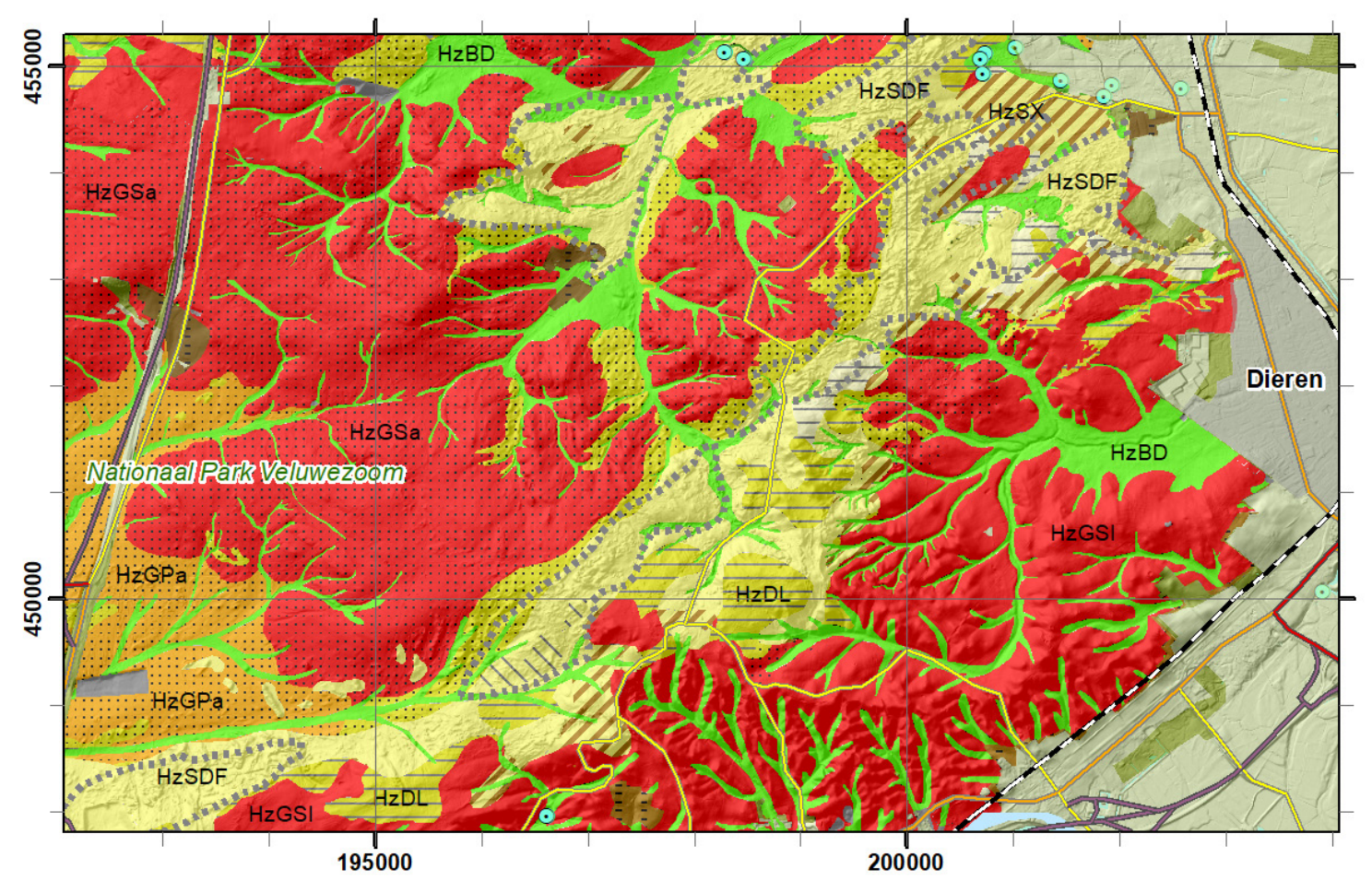

Figuur 4.3 Landschappelijke bodemkaart van Natura 2000-gebied Veluwe, uitsnede stuwwallen Veluwezoom. Legenda zie Figuur 4.2.

Op de glaciale afzettingen zijn vaak weer dekzanden (HzD) of stuifzanden (HzS) afgezet, deels van lokale oorsprong, maar ook van elders (vooral bij de dekzanden). De stuifzanden zijn vaak ontstaan door verstuiving van dekzanden. Waar deze afzettingen op het glaciaal voorkomen, zijn de FG-secties $\mathrm{HzD}$ of $\mathrm{HzS}$ gekarteerd. Door het smeltwater zijn in de stuwwallen en puinwaaiers droogdalen (HzBD) uitgesleten die in enkele gevallen functioneren als beekdalen $(\mathrm{HzB})$, zoals o.a. het geval is bij de Renkumse en Heelsumse beek (Figuur 4.4) en de Staverdense-Hierdense beek.

Een belangrijk onderscheid voor zowel de stuwwallen als de puinwaaiers is het leemgehalte. De legenda van de Bodemkaart van Nederland (De Bakker \& Schelling, 1989; Ten Cate et al., 1995) geeft daar slechts beperkt informatie over. Bij grofzandige afzettingen (textuurcode 30) geeft deze legenda geen uitsluitsel over het leemgehalte, terwijl dit juist bij gestuwde afzettingen enorm kan variëren. Om toch een onderscheid te kunnen maken, gebruiken wij de bodemvorming in de grove zanden als criterium. Door Spek (1993, § 2.2 Bodemvormende processen) en Spek (2004, p. 119 Het podzoleringsproces) werd vastgesteld dat moderpodzolgronden vooral gevormd worden in lemige grove zanden met een in mineralogisch opzicht wat rijker moedermateriaal. In leemarme grove zanden worden vooral haarpodzolgronden gevormd. Wij interpreteren deze eenheden voor de bodemkaart van Nederland als volgt: 
HzGSI Lemige stuwwallen en HzGPI Lemige puinwaaiers

- Bodemeenheden met textuurcode 23 of L én Y30

- Of tussen 40 en $120 \mathrm{~cm}$-mv met keileem of tertiaire klei (toevoeging $\mathrm{x}$ of $\mathrm{t}$ achter de bodemcode; NB komt niet voor op de Veluwe)

HzGSa Leemarme stuwwallen en HzGPa Leemarme puinwaaiers

- Bodemeenheden met textuurcode 21 zonder toevoeging $\mathrm{x}$ of $\mathrm{t}$

- Hd30 en Hn30

Dit neemt niet weg dat binnen de Y30 ook leemarme zanden voor kunnen komen en binnen Hd30 lemige. Deze indeling geeft de grote lijn aan voor het interpreteren van de beperkte informatie op de Bodemkaart van Nederland. Detailkarteringen geven wat dat betreft eenduidiger informatie (zie Bijlage 6).

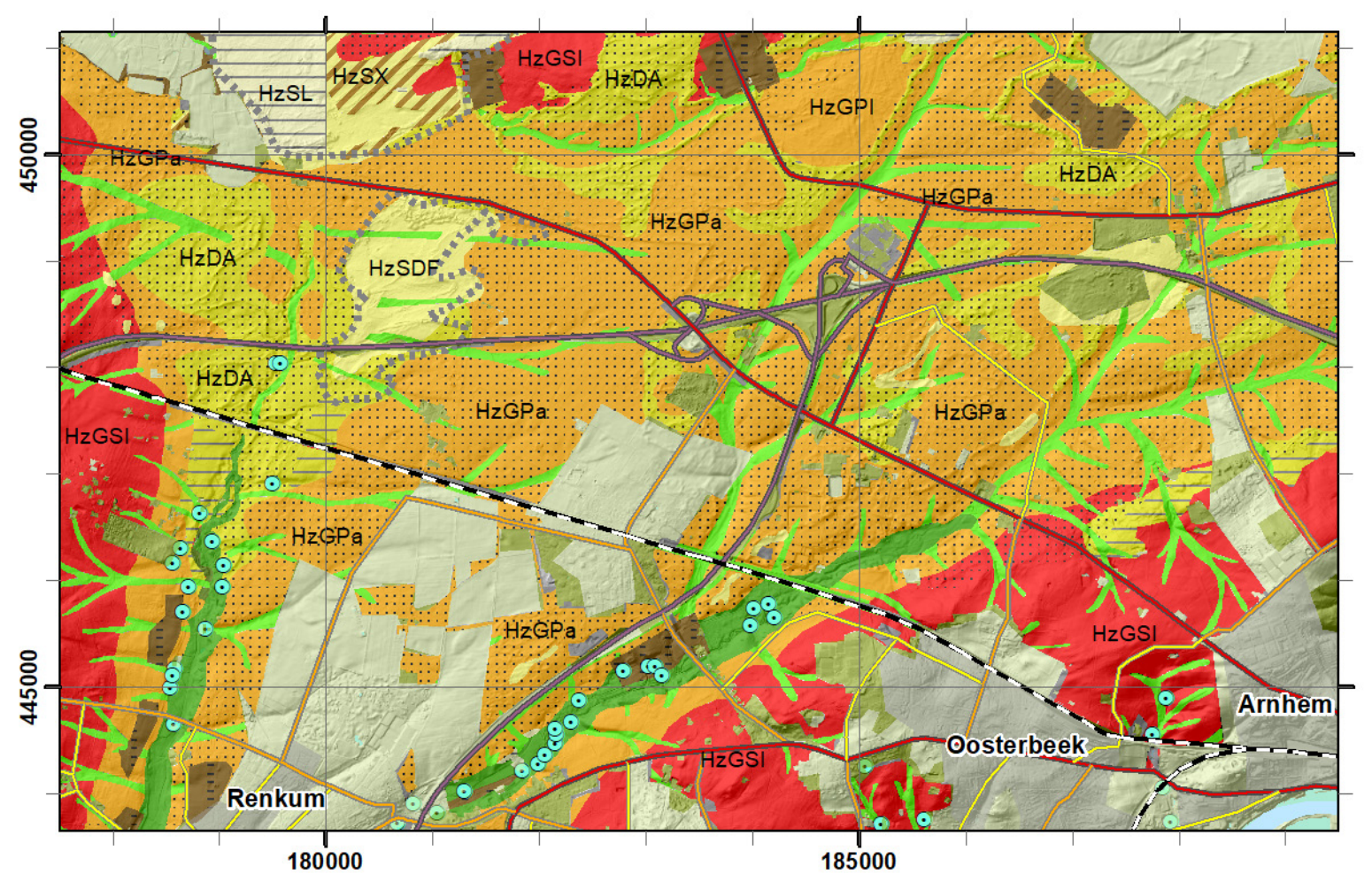

Figuur 4.4 Landschappelijke bodemkaart van Natura 2000-gebied Veluwe, uitsnede puinwaaiers tussen de stuwwallen van Arnhem en Wageningen, met de beekdalen van de Renkumse en Heelsumse beken. (Legenda: zie Figuur 4.2.)

\section{Mineralogische verschillen}

Een mogelijk belangrijk verschil binnen de glaciale afzettingen vormt de oorsprong van het gestuwde materiaal en vervolgens het verspoelde materiaal in de puinwaaiers. Op de noordelijke Veluwe betreft het hier vooral mineralogisch arme, kwartsrijke zanden van de voormalige Eridanos rivier (Jongmans et al., 2012). De afzettingen van de Eridanos komen overeen met de formaties van Peize en Appelscha en bestaan uit wit zand met zeer weinig kleilagen (Figuur 4.5). Naar het westen en zuiden bestaan de stuwwallen steeds meer uit bruine Rijnzanden (Formaties van Urk, Sterksel en Waalre) en zelfs Maaszanden (Formatie van Beegden). De bruine kleur laat zien dat deze zanden gevarieerder van samenstelling zijn en daardoor mineralogisch rijker (o.a. ijzerhoudende mineralen).

Dit verschil in mineralogie zal van invloed zijn op de natuurpotenties voor de glaciale afzettingen in de verschillende deelgebieden van Natura 2000-gebied Veluwe. Er bestaat echter geen kaart waar het voorkomen van beide typen zanden op is aangegeven. Een mogelijke indicatie zijn de textuur en bodemvorming op de Bodemkaart van Nederland (Figuur 4.6). Verwacht mag worden dat zich in de 'arme' Eridanos-zanden eerder een haarpodzolgrond zal ontwikkelen en dat moderpodzolgronden 
eerder te verwachten zijn in de bruine Rijnzanden. Het lijkt er dan op dat de witte zanden vooral te vinden zijn ten noorden van de lijn Harderwijk-Epe. Ten zuiden daarvan worden vaker

holtpodzolgronden (in Rijnzanden) gevonden, met uitzondering van een brede band, globaal tussen Eerbeek en Renkum en wat kleinere vlakken verspreid. Opvallend is dat de lemige fijne zanden (Y23, $\mathrm{Hd} 23$ ) vooral voor lijken te komen in de overgangszone van overwegend $\mathrm{Hd} 30$ in het noorden en overwegend Y30 ten zuiden van de weg van Nunspeet naar Epe en zuidelijk van Nunspeet.

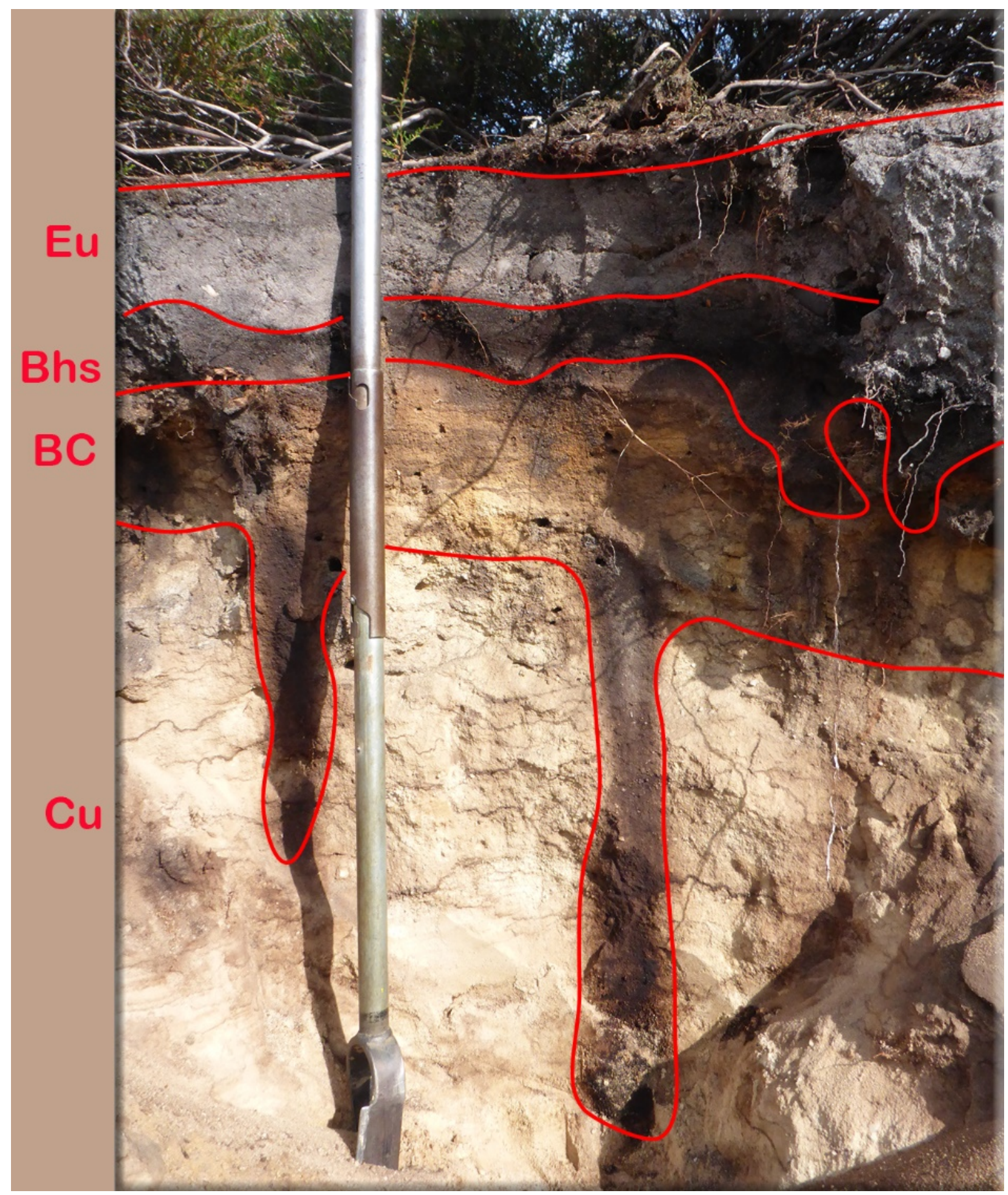

Figuur 4.5 Haarpodzolgrond in Eridanos-zand (HzGSa) op de Archemerberg (Overijssel). 


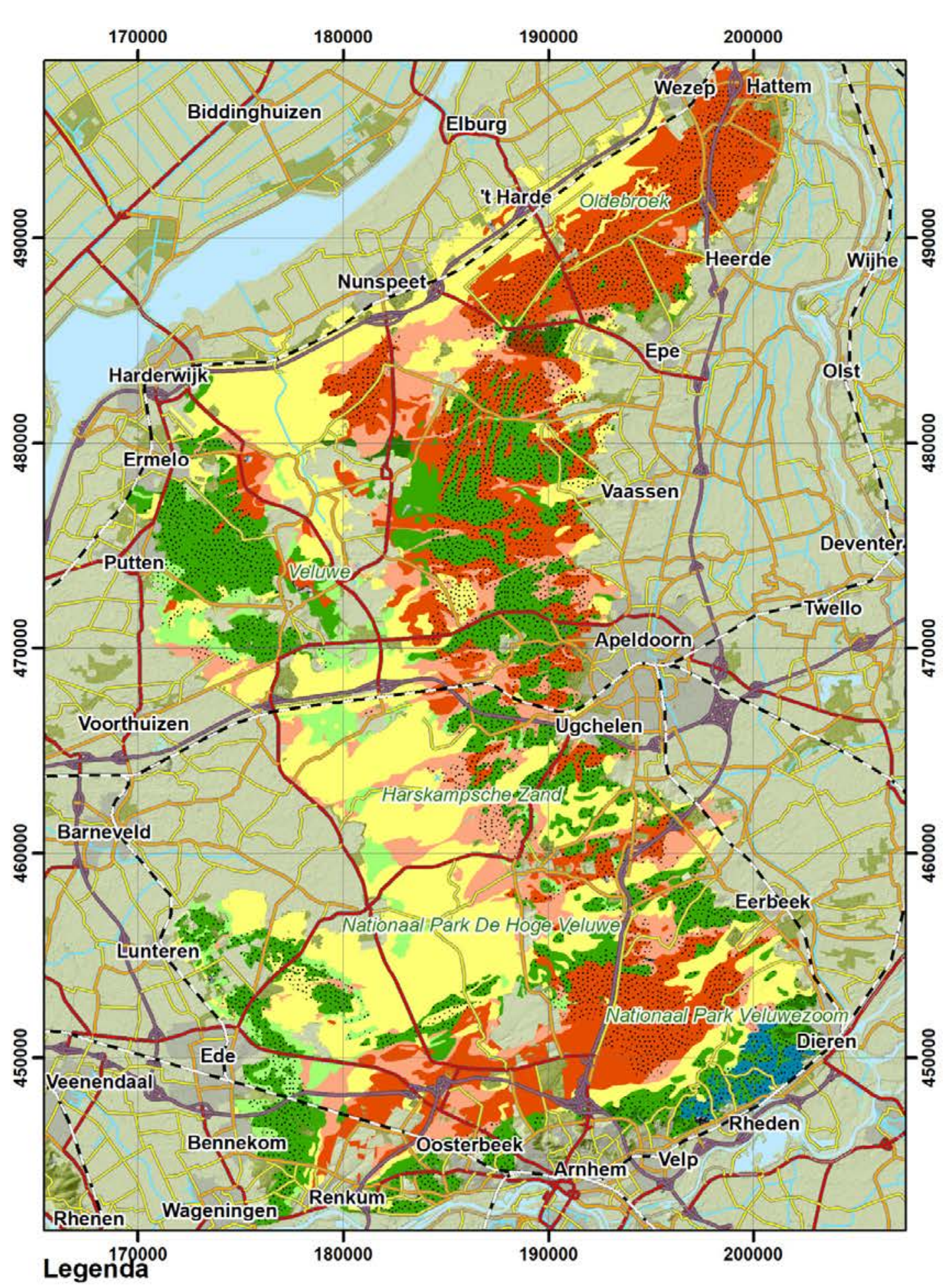

o. Stuwwallen

Overig

\section{Moderpodzolgronden}

Y21 Holtpodzolgronden; leemarm en zwak lemig fijn zand

Y30 Holtpodzolgronden; grof zand

Y23 Holtpodzolgronden; lemig fijn zand

\section{Humuspodzolgronden}

Hd21 Haarpodzolgronden; leemarm en zwak lemig fijn zand

Hd30 Haarpodzolgronden; grof zand

Hd23 Haarpodzolgronden; lemig fijn zand

\section{Leemgronden}

Ld5 Ooivaaggronden met roest beginnend dieper dan $80 \mathrm{~cm}$; zandige leem in situ

Figuur 4.6 Verbreiding van moderpodzolgronden, humuspodzolgronden en leemgronden binnen Natura 2000-gebied Veluwe (bron: BRO-loket). 


\subsubsection{HzS Stuifzandgebieden}

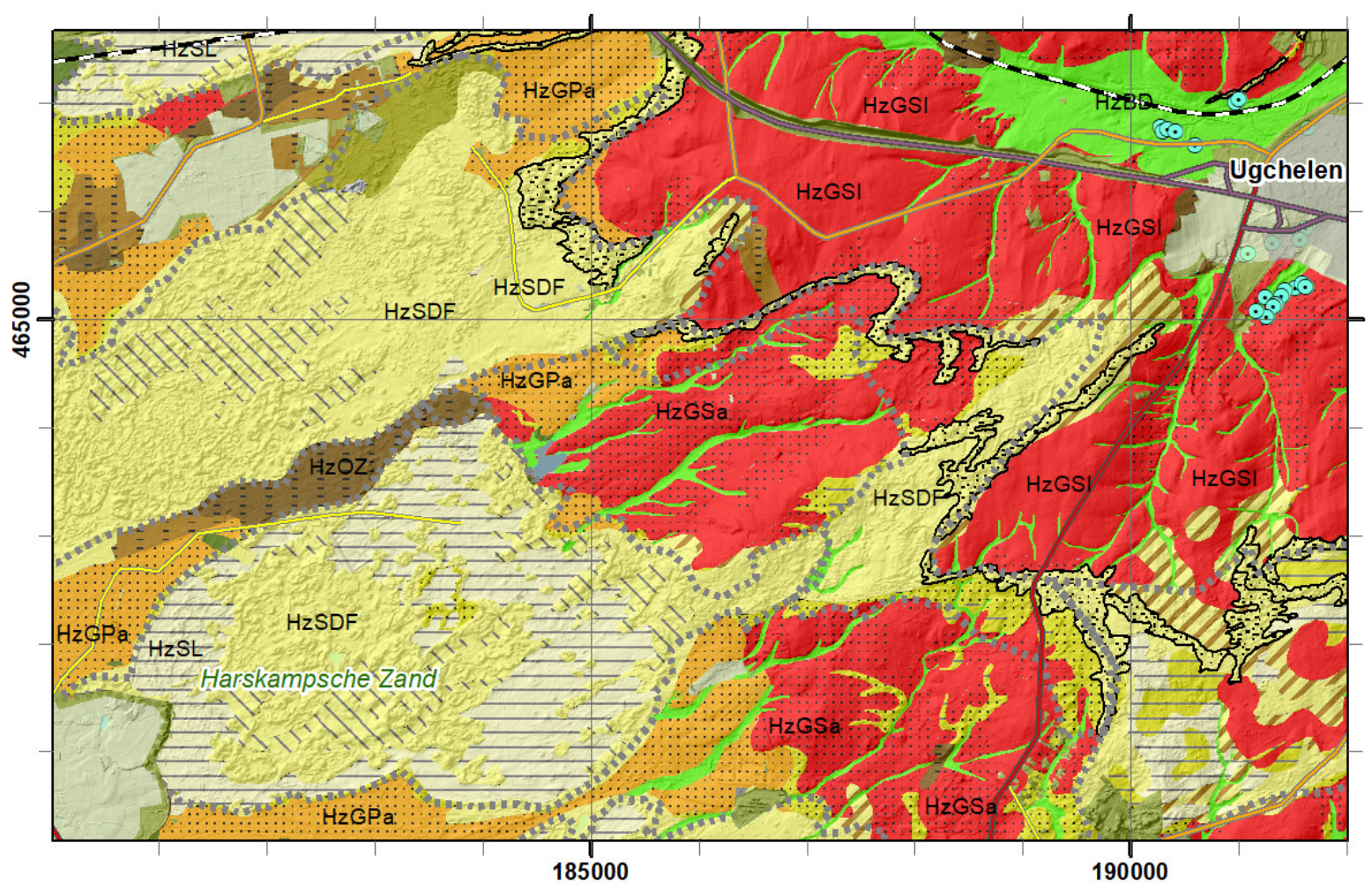

Figuur 4.7 Landschappelijke bodemkaart van Natura 2000-gebied Veluwe, uitsnede stuifzandgebieden bij Harskamp. De grijze bloklijntjes geven de begrenzing aan van stuifzandcellen volgens Riksen \& Jungerius (zie ook Koomen et al., 2004), de vlakken met zwarte spikkels in de eenheid HzSDF geven de randwallen aan (Koomen \& Maas, 2009). (Legenda: zie Figuur 4.2.)

Als belangrijkste processen binnen stuifzandgebieden gelden enerzijds het uitstuiven van bestaande bodems (meestal dekzand) en anderzijds het afzetten van dit stuifzand verderop, boven op een bestaande bodem of een reeds eerder afgestoven bodem. Door Koster (1978) worden hiervoor vijf eenheden onderscheiden, die ook terugkomen in de FG-series van de stuifzandgebieden (Figuur 4.8).

Er worden in de Landschapsleutel drie FG-series onderscheiden:

- Uitgestoven laagten ( $\mathrm{HzSL}$ ) komen voor, waar het oude bodemprofiel door verstuiving is verdwenen en hooguit een dunne laag $(<40 \mathrm{~cm}$ ) stuifzand voorkomt (uitgestoven of doorgestoven). Deze bodems zijn vaak zeer slecht doorwortelbaar en hebben dan ook, zeker bij diepe grondwaterstanden een zeer beperkte vochtvoorziening. Voor zover zij voorkomen binnen glaciale gebieden (HzG), ligt aan maaiveld vaak veel grind (desert pavement, keienvloertje).

- Forten en Overstoven laagten (HzSF), waarbij 40 tot $180 \mathrm{~cm}$ stuifzand voorkomt op een overstoven profiel (overgestoven) of op een eerder afgestoven bodem (opgestoven). Afhankelijk van het type bodem onder het stuifzand en de dikte van het stuifzandpakket kan in deze bodems infiltrerend neerslagwater (tijdelijk) stagneren, waardoor deze gronden een goede vochtvoorziening hebben, vaak ook voor de ondergroei.

- Landduinen (HzSD); dit zijn dikke stuifzandgronden waarbij binnen boorbereik $(180 \mathrm{~cm})$ niet achterhaald kan worden welk bodemtype eronder voorkomt (Ondergestoven). Deze bodems zijn zeer diep doorwortelbaar en hebben daardoor voor diep wortelende planten, zoals bomen, een goede vochtvoorziening. Voor ondiep wortelende ondergroei is de vochtvoorziening beperkt. 

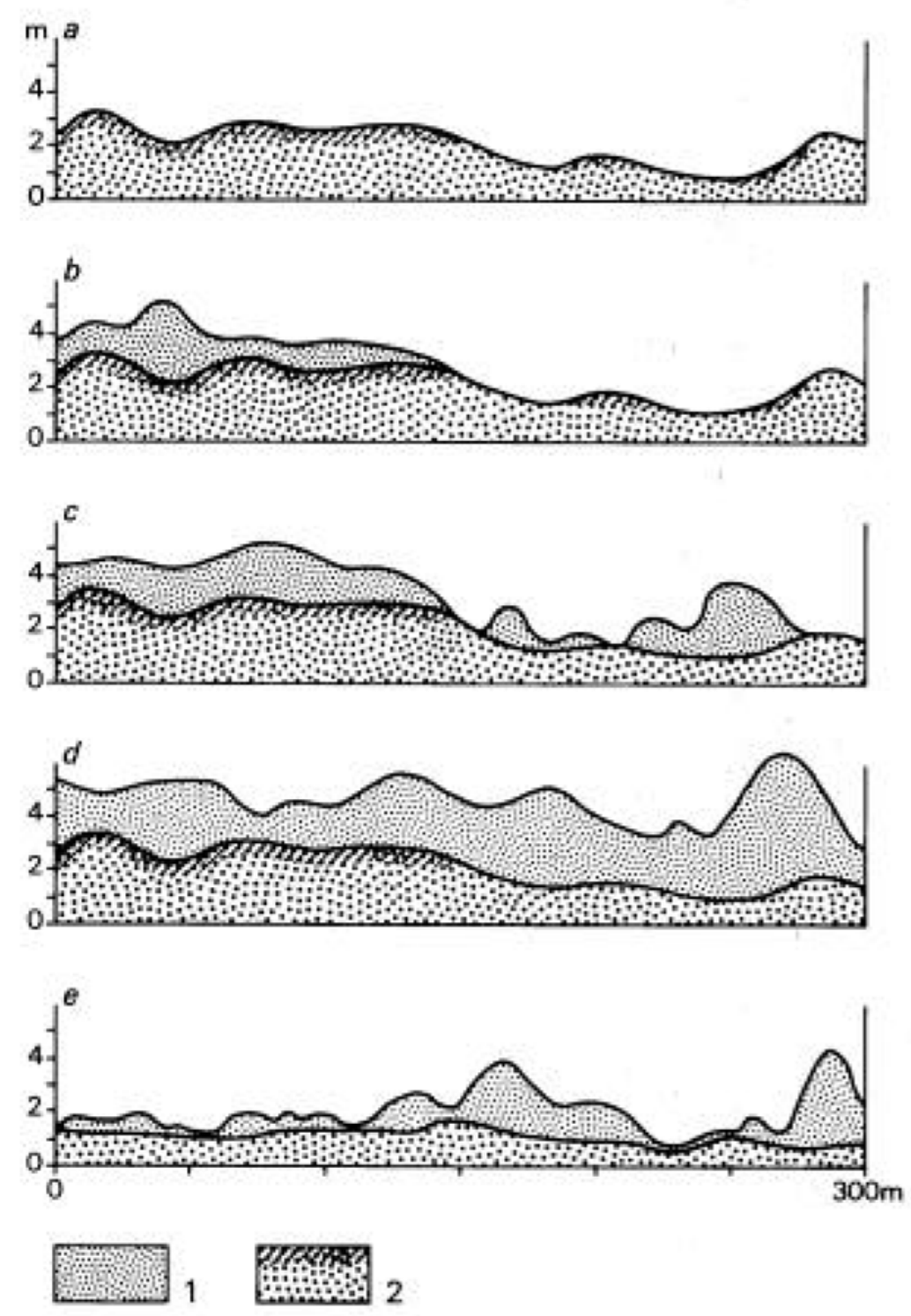

Figuur 4.8 Schematische weergave van de eenheden in stuifzandgebieden (Koster, 1978).

a. niet door verstuiving aangetast (dekzand)oppervlak en 'uitgestoven' terrein

b. 'overgestoven' en 'uitgestoven' terreinen

c. 'overgestoven' en 'opgestoven' terreinen

d. 'ondergestoven' terrein

e. 'doorgestoven' terrein

1. Stuifzand

2. Dekzand

Omdat de Bodemkaart van Nederland onvoldoende informatie geeft om dit onderscheid goed te maken, hebben wij op de Landschappelijke bodemkaart een tweetal samengestelde eenheden moeten opnemen:

- HzSDF Landduinen, Forten en Overstoven laagten: ruggen, koppen e.d. waarbij niet duidelijk is of het gaat om landduinen of overstoven bodems;

- HzSX Stuifzandcomplexen: als ook het onderscheid met laagten niet goed gemaakt kan worden en bijvoorbeeld de bodemcode AS (associatie van stuifzandgronden) is gebruikt, is verder onderscheid niet mogelijk.

Zeker voor stuifzandgebieden geldt dat voor een goede analyse op deelgebiedsniveau bij voorkeur een detailbodemkaart geraadpleegd moet worden (zie Bijlage 6). Het patroon van stuifzandgebieden is te kleinschalig om op een landelijke kaart goed weer te geven. 


\section{Stuifzandcellen}

Stuifzandgebieden zijn vaak te herkennen als samenhangende eenheden of 'stuifzandcellen' (Koomen et al., 2004; zie Figuur 4.7). Binnen deze cellen is vaak een vast patroon te herkennen, met in grote lijnen een relatief laaggelegen zone met kopjesduinen en uitgestoven laagten in het zuidwesten, een centrale stuifvlakte met resten podzolbodems en in het oosten een accumulatiezone met langgerekte ruggen en paraboolduinen. Bij een actief stuifzandgebied vindt uitbreiding plaats in zuidwestelijke richting door 'terugschrijdende erosie' (tegen de overheersende windrichting in) en in noordoostelijke richting door overstuiving van bestaande bodems. Dat betekent dat er ook voor de FG-series van de stuifzandgebieden per stuifzandcel een opeenvolging is te verwachten van HzSL 'Uitgestoven laagten' in het zuidwesten, naar HzSF 'Forten en Overstoven laagten' en HzSD 'Landduinen' in het noordoosten. Uiteraard komen deze eenheden ook door elkaar voor, maar het aandeel van de verschillende FG-series zal in die richting verschuiven. De door Riksen \& Jungerius onderscheiden stuifzandcellen (Koomen et al., 2004) zijn als een aparte kaartlaag opgenomen in de Landschappelijke bodemkaart (Figuur 4.7).

\section{Randwallen}

Aan de noordoost- of oostkant worden veel stuifzandcellen begrensd door een paraboolduin of randwal die vaak de overgang markeert naar bos of ontginning ten tijde van de verstuiving (Koster, 1968; Bijlsma, 2002; Koomen \& Maas, 2009). Het bos werkt dan als invang voor het stuifzand, waardoor hier sterke accumulatie van stuifzand kan optreden. Het resultaat is vaak een meer dan 10 meter hoog eindparaboolduin. Door Koomen \& Maas zijn deze wallen gekarteerd. Wij hebben deze gebruikt om de eenheid HzSDF mede af te grenzen. Randwallen die meters dik zijn, kunnen dan als HzSD beschouwd worden, maar dat kunnen wij op basis van de Bodemkaart van Nederland niet bepalen. Daarvoor is een detailkartering noodzakelijk. Op de Landschappelijke bodemkaart hebben wij de randwallen als aparte kaartlaag aangegeven.

\section{Actief stuifzand}

Veel stuifzand is vastgelegd door aanplant van bos of door successie naar stuifzandvegetaties en heide. Het voorkomen van actief stuifzand is in kaart gebracht door gebruik te maken van het veld 'active' in het bestand van de geomorfologische kaart. Op de Landschappelijke bodemkaart is dit aangegeven met een letter ' $a$ ' achter de code van de FG-series binnen stuifzandgebieden en een schuine arcering in het kaartvlak. Een andere bron om dit onderscheid te maken, is het bestand 'Landelijk Grondgebruik Nederland' (LGN), waarbij code 35 'Open stuifzand of rivierzand' aangeeft waar actief stuifzand voorkomt. Dat hebben wij hier niet gedaan, maar kan bij de beoordeling in deelgebieden wel extra inzicht geven. Het voordeel van LGN is dat het gebaseerd is op recente satellietobservaties en zeer gedetailleerd is. 


\subsubsection{HzD Dekzandgebieden}

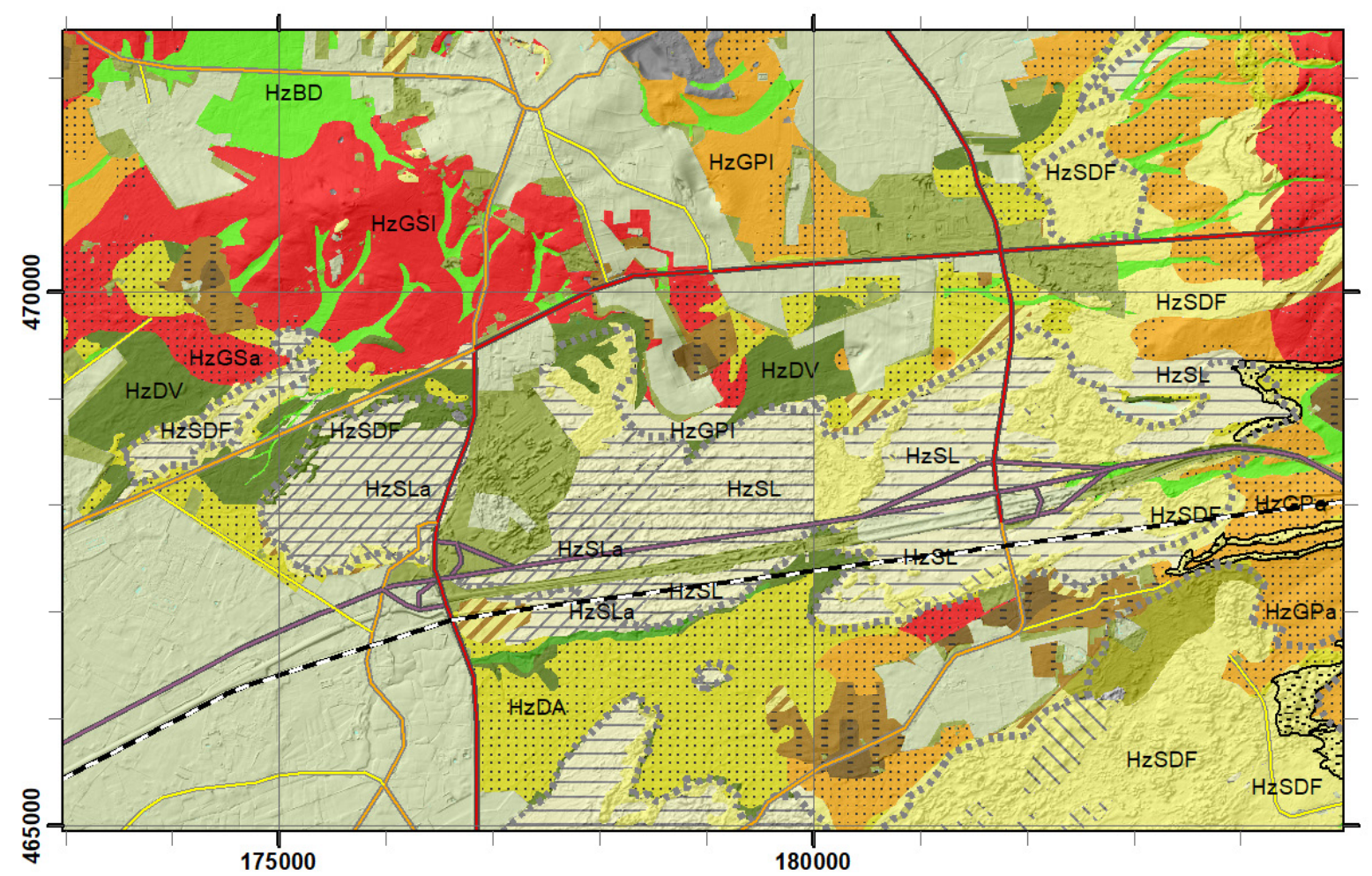

Figuur 4.9 Landschappelijke bodemkaart van Natura 2000-gebied Veluwe, uitsnede met o.a. dekzandgebieden aan de rand van de Gelderse Vallei bij Voorthuizen. (Legenda: zie Figuur 4.2.)

In vergelijking met de glaciale gebieden $(\mathrm{HzG})$ en stuifzandgebieden $(\mathrm{HzS})$ spelen de dekzandgebieden binnen Natura 2000-gebied Veluwe een ondergeschikte rol. Zij zijn veelal te vinden als zogenaamde gordeldekzandgebieden langs de flanken van stuwwallen, maar vaak ook weer door verstuiving overgegaan in stuifzandgebieden (Figuur 4.9). Binnen dit gebied komen vier FG-series van de dekzand-gebieden voor:

- HzDA Leemarme droge dekzandgebieden: dit zijn vooral dekzandruggen met leemarm dekzand waar meestal een haarpodzolgrond in voorkomt (Hd21);

- HzDL Lemige dekzandgebieden en dekzand op leem: dekzandruggen en welvingen in lemig zand of met leem in de ondergrond (niet op de Veluwe);

- HzDV Vochtige dekzandlaagten: laaggelegen dekzandgronden, vaak met veldpodzolgronden (Hn21 of Hn23), gooreerdgronden ( $\mathrm{pZn21}$ of pZn23) of beekeerdgronden (pZg21 pZg23), voor zover buiten de beekdalen;

- HzDG Grondwatergevoede vennen: dit is een categorie apart die binnen de Landschapsleutel ondergebracht is bij de dekzandgebieden, maar ook voor kan komen binnen glaciale gebieden. Het betreft veengronden en moerige gronden buiten de beekdalen, die indiceren voor gebufferd grondwater. Dat leiden wij af uit het voorkomen van zeggeveen (.Vc), broekveen (.Vb) of het ontbreken van een podzol in de minerale ondergrond $(. V z, . W z)$. 


\subsubsection{HzB Beekdalen en droogdalen}

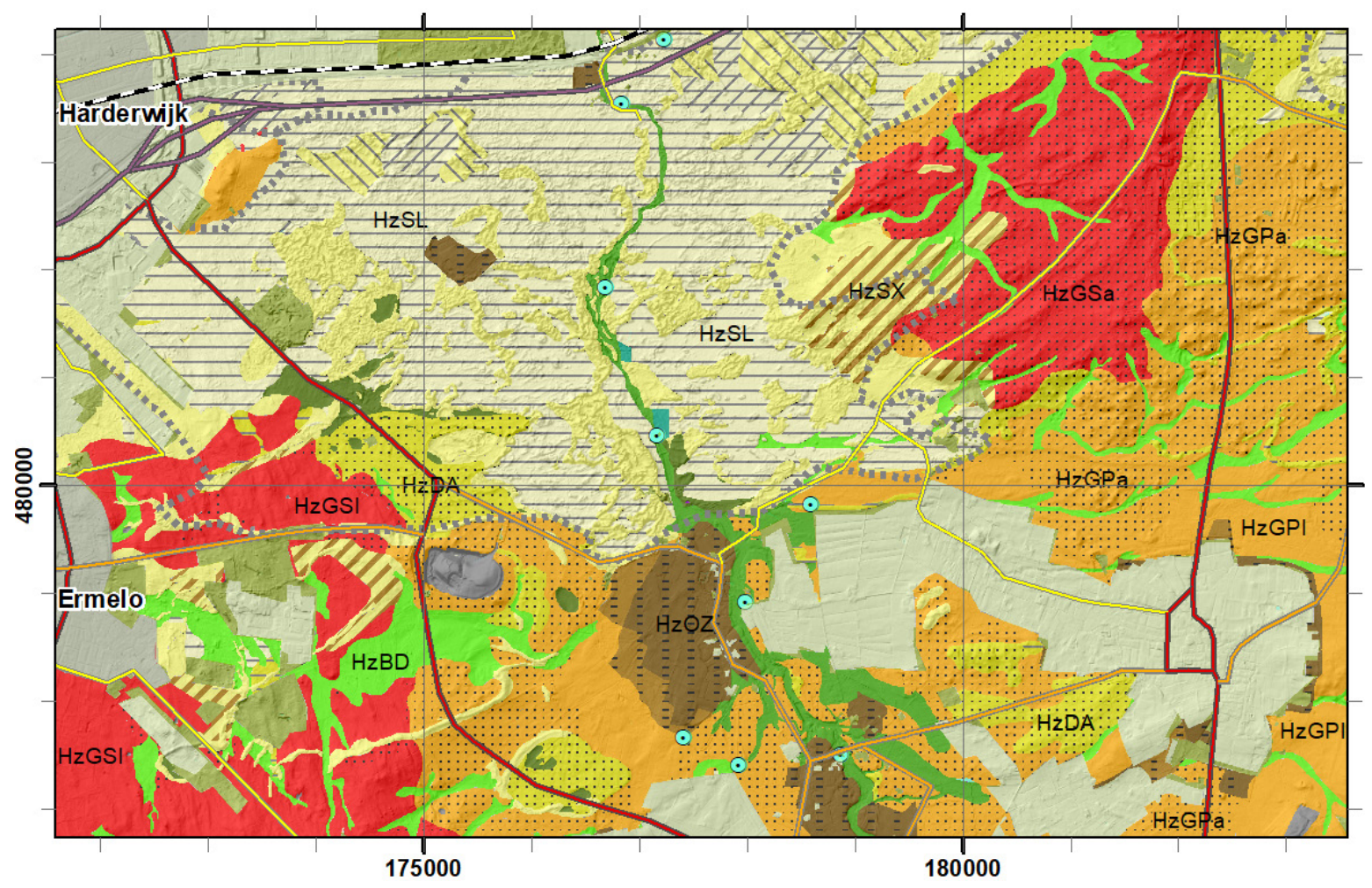

Figuur 4.10 Landschappelijke bodemkaart van Natura 2000-gebied Veluwe, uitsnede met o.a. het beekdal van de Staverdense en Hierdense beek. (Legenda: zie Figuur 4.2.)

De beekdalen (inclusief droogdalen) vormen een FG-sectie die dwars door de andere FG-secties lopen, waarin zij zijn ingesneden. Er zijn veel overgangen met andere FG-secties of FG-regio's. De bovenlopen van beekdalen komen vaak overeen met vochtige dekzandlaagten of sluiten aan op (droge) dalen in Glaciale gebieden. Daarbij kunnen storende lagen (keileem, tertiaire klei etc.) de reden zijn van het voorkomen van Brongebieden ( $\mathrm{HzBB})$. Natte en verdroogde beekdalen ( $\mathrm{HzBN}$ ) vertonen ook veel overeenkomsten met de vochtige dekzandlaagten. Stroomafwaarts vormen Benedenlopen en lemige beekvlakten ( $\mathrm{HzBV}$ ) overgangen naar Laagveengebieden, het Zeekleigebied of Rivierengebied.

Al deze verschillende elementen en met name de Brongebieden, Beekoeverwallen ( $\mathrm{HzBW}$ ) en Beeklopen ( $\mathrm{HzBL}$ ) kunnen vaak niet op basis van landelijke kaarten onderscheiden worden en behoeven een gedetailleerde bodemkaart om de verschillende FG-typen goed in beeld te brengen:

- HzBB Brongebieden: zeer natte, kwelgevoede bodems (.Wz, Wo, $V c, V z, V b)$ op stuwwallen en in droogdalen interpreteren wij als brongebieden. Daarnaast hebben wij gebruikgemaakt van een GISbestand met sprengkoppen (Koomen \& Maas, 2009); voor de Veluwe: zie ook Menke et al. (2007).

- HzBL Beeklopen: dit betreft de beek met directe oevers. Deze eenheid speelt vanzelfsprekend een belangrijke rol bij de beoordeling van deelgebieden, maar kon op de Landschappelijke bodemkaart niet volledig worden onderscheiden Beeklopen zijn goed uit topografische informatie af te leiden. Voor de Veluwe: zie Menke et al. (2007).

- HzBW Beekoeverwallen: ook deze FG-serie kunnen wij op deze schaal niet onderscheiden, maar is wel van belang. Op deelgebiedsniveau zijn deze vormen mogelijk af te leiden van detailkarteringen of terreinkennis. Ook bestudering van het AHN kan hier inzicht in verschaffen.

- HzBN Natte en verdroogde beekdalen: dit is een grote groep eenheden die met de landelijke bestanden niet goed te onderscheiden is en ook niet bij een ander deel van beekdalsysteem is onder te brengen. Deze eenheid omvat zowel de flanken (veldpodzolgronden en gooreerdgronden) als delen van de dalbodem met beekeerdgronden van de grotere beekdalen zoals Staverdense/Hierdense beek, Renkumse beek, Heelsumse beek. 
- HzBV Benedenlopen en lemige beekvlakten: deze worden onderscheiden op basis van het voorkomen van kleidekken op de bodem (toevoeging k..) voor de bodemcode of kleigronden (Rn..) in de beekdalen.

- HzBD Droogdalen: de droogdalen zijn in het Pleistoceen ontstaan onder invloed van smeltwater en komen overal in de glaciale gebieden voor. Momenteel zijn zij niet meer watervoerend. Een deel van de droogdalen gaat naar beneden toe over in een beekdal. In dit overgangsgebied zijn vaak sprengkoppen uitgegraven om de watervoorziening van watermolens te verbeteren. De sprengkoppen hebben wij ondergebracht bij de brongebieden.

\subsection{5 $\mathrm{HzO}$ Oude bouwlanden}

De oude bouwlanden onderscheiden wij, in tegenstelling tot de eerste versie van de Landschapsleutel (Kemmers et al., 2011), als aparte FG-sectie. Zij zijn ontstaan vanuit verschillende zandgronden binnen de andere FG-secties, maar hebben door het agrarisch gebruik een essentieel ander karakter gekregen dan de oorspronkelijke bodem waar zij uit ontstaan zijn. De oude bouwlanden zijn meestal te vinden op de overgang van hogere naar lagere gronden, wat voor Natura 2000-gebied Veluwe betekent dat zij veelal aan de randen te vinden zijn. Afhankelijk van de oorspronkelijke bodem en de herkomst van het opgebrachte plaggenmateriaal kunnen hier twee FG-series onderscheiden worden:

- HzOZ Zwarte eerdgronden: meestal ontstaan op mineraalarme bodems (Hd.., Hn..) door bemesting met heideplaggen. Deze FG-serie omvat de hoge zwarte enkeerdgronden (zEZ..) en humuspodzolgronden met een matig dikke minerale eerdlaag (cHn..., cHd..).

- HzOB Bruine eerdgronden: deze zijn meestal ontstaan op mineraalrijkere bodems, maar ook de samenstelling van het plaggenmateriaal is van belang. Omdat deze bodems in een rijkere omgeving liggen, bevatte het opgebrachte materiaal (van grasheide of bosstrooisel) ook meer mineralen waardoor deze bodems een bruine minerale eerdlaag hebben gekregen. Deze FG-serie omvat de hoge bruine enkeerdgronden (bEZ..) en moderpodzolgronden met een matig dikke minerale eerdlaag $(\mathrm{cY} . .$,$) .$ 


\section{$5 \quad$ Historisch landgebruik}

\subsection{Achtergrond en werkwijze}

De eerste landsdekkende topografische kaart van rond 1850 (Topographische en Militaire Kaart, TMK) geeft een beeld van de ligging en samenhang van cultuurgronden en woeste gronden voorafgaand aan grote veranderingen in landgebruik, o.a. als gevolg van het opheffen van de marken. De TMK is afgeleid van kadastrale kaarten (minuutplans) die in 1832 landelijk beschikbaar kwamen met de installatie van het kadaster. Deze kaarten geven een nauwkeurig beeld van het landgebruik in de vroege $19^{\text {de }}$ eeuw. Per perceel is, naast landgebruik en eigendom, ook een belastingklasse en -tarief toegekend. Dit tarief is gebaseerd op de geschatte of gerealiseerde productiviteit van het perceel en is daarmee ecologisch relevant (o.a. Bijlsma et al., 2013): het geeft een beeld van de productiviteit van het landschap voordat kunstmest en kunstmatige atmosferische zwavel- en stikstofdepositie een grote rol gingen spelen.

Aangezien de klassering van landgebruik per kadastrale gemeente werd bepaald (binnen landelijk afgesproken voorwaarden: Veldhorst 1991; Kadaster 2014), kan bijvoorbeeld de oppervlakte bos klasse 2 niet zonder meer worden vergeleken tussen gemeenten. Om landgebruik toch te kunnen vergelijken, wordt een geharmoniseerde klassenindeling gebruikt, opgesteld op basis van een groot aantal gemeentelijke tarieflijsten voor bos, heide, dennenbos, bouwland en weiland (Bijlsma, 2018; zie Tabel 5.1 en Bijlage 8.1). Bos klasse 6 is toegevoegd voor bos met tarief $<f 1,50$ (in feite heide met struiken) en evenzo heide klasse 0 voor heide met tarief $>$ f 1 ,- (in feite heideachtig bos). Deze indeling is toegepast op een door R.J. Bijlsma vervaardigde mozaïek van gevectoriseerde en gegeorefereerde kadastrale kaarten 1832 van de Veluwe. ${ }^{14}$

Tabel 5.1 Categorieën landgebruik in 1832 (kadaster) met geharmoniseerd tarief volgens Bijlsma (2018) en in 1900, 1960 en 2000 (rasterbestanden HGN) met gridcodes.

\begin{tabular}{|c|c|c|c|c|c|}
\hline Landgebruik 1832 & $\begin{array}{l}\text { Tarief } 1832 \\
\text { (fI) }\end{array}$ & HGN 1900 & $\begin{array}{l}\text { GridCode HGN } \\
1900\end{array}$ & $\begin{array}{l}\text { HGN } 1960 \\
\text { HGN } 2000\end{array}$ & $\begin{array}{l}\text { GridCode HGN } \\
1960 \\
\text { HGN } 2000\end{array}$ \\
\hline Bos 1/Opgaand bos 1 & $>19$ & \multirow{5}{*}{ Loofbos } & \multirow{5}{*}{4} & \multirow{5}{*}{ Bos } & \multirow{5}{*}{4} \\
\hline Bos 2/Opgaand bos 2 & $13-19$ & & & & \\
\hline Bos 4/Opgaand bos 4 & $5-8$ & & & & \\
\hline Bos 5/Opgaand bos 5 & $1.5-4$ & & & & \\
\hline Bos 6 & $<1.5$ & & & & \\
\hline Struiken & & \multirow{3}{*}{$\begin{array}{l}\text { Heide en } \\
\text { hoogveen }\end{array}$} & \multirow[t]{3}{*}{3} & \multirow{3}{*}{$\begin{array}{l}\text { Heide en } \\
\text { hoogveen }\end{array}$} & \multirow[t]{3}{*}{3} \\
\hline Heide & onbelast & & & & \\
\hline Heide 3 & 0.25 & & & & \\
\hline Zand & 0.25 & $\begin{array}{l}\text { Stuifzanden en } \\
\text { zandplaten }\end{array}$ & 9 & $\begin{array}{l}\text { Stuifzanden en } \\
\text { zandplaten }\end{array}$ & 9 \\
\hline Moeras & & Rietmoeras & 8 & Rietmoeras & 8 \\
\hline Elzenwilgenbos & & Loofbos & 4 & Bos & 4 \\
\hline Dennenbos & onbelast & \multirow[t]{4}{*}{ Naaldbos } & \multirow[t]{4}{*}{5} & \multirow[t]{4}{*}{ Bos } & \multirow[t]{4}{*}{4} \\
\hline Dennenbos 1 & $>6$ & & & & \\
\hline Dennenbos 2 & $4-6$ & & & & \\
\hline Dennenbos 3 & $<4$ & & & & \\
\hline
\end{tabular}

\footnotetext{
${ }^{14}$ Deze kaart is ter beschikking gesteld aan HISGIS en daar te raadplegen als onderdeel van de kadastrale kaart van Gelderland: https://hisgis.nl/projecten/gelderland/
} 


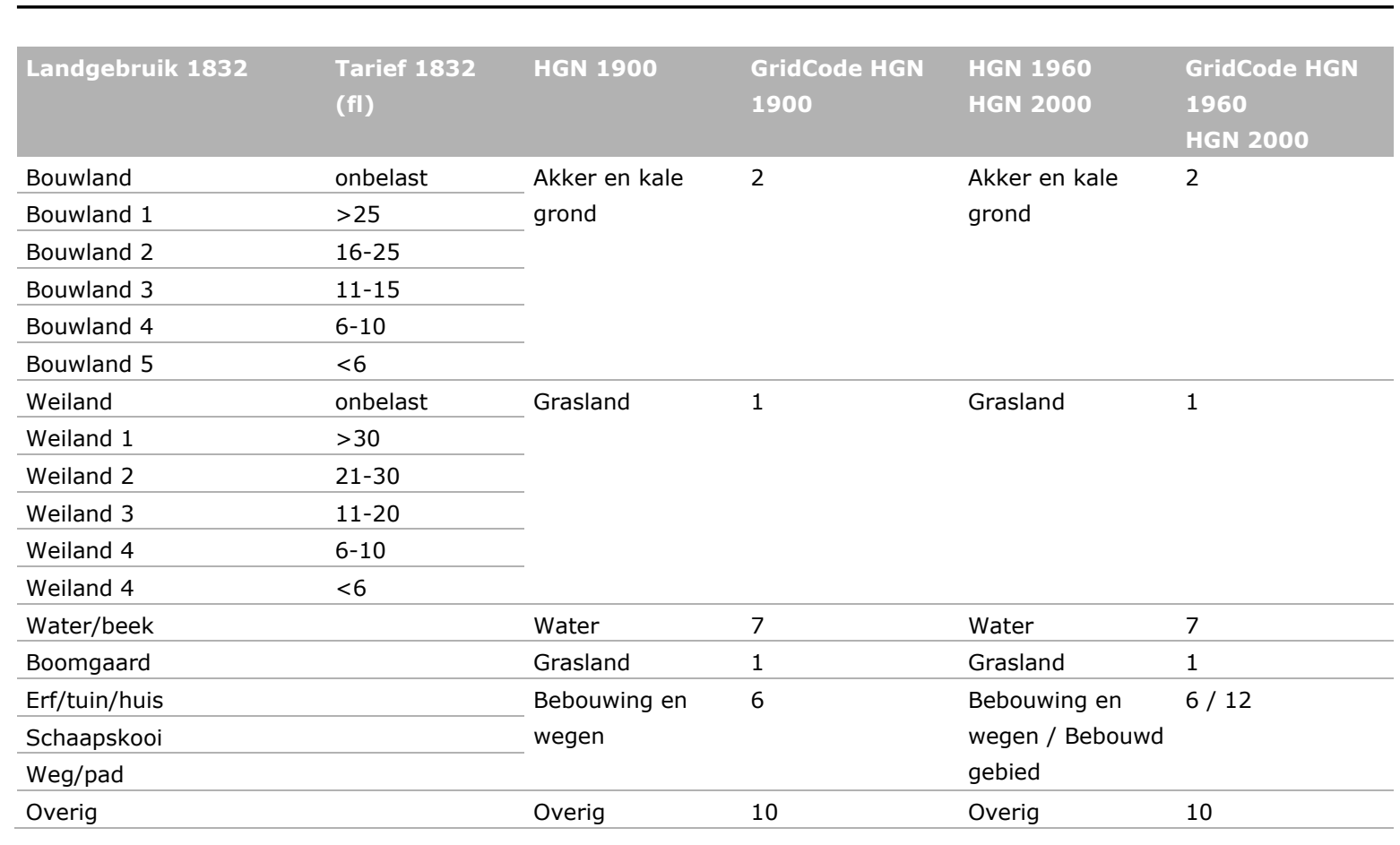

Veranderingen in landgebruik vanaf het begin van de $20^{\text {ste }}$ eeuw kunnen worden geanalyseerd met de rasterbestanden Historisch Grondgebruik Nederland voor o.a. 1900, 1960 en 2000. De eerste twee zijn afgeleid van de betreffende Bonne-kaarten, waarbij HGN1900 een resolutie heeft van 50x50 m en de HGN-bestanden van 1960, 1970 en 1990 een resolutie van 25x25 m (Knol et al., 2004; Kramer \& Van Dorland, 2009). HGN2000 is afgeleid van het bestand Landelijk Grondgebruik Nederland 4 met eenzelfde resolutie en legenda als HGN1960. In Tabel 5.1 zijn ook de HGN-legenda's opgenomen.

Bijlage 8.2-8.3 geven de verdelingen van historisch grondgebruik weer in respectievelijk 1900, 1960 en 2000 per fysisch-geografische serie (en omgekeerd) binnen het Natura 2000-gebied Veluwe.

Ter illustratie geeft Figuur 5.1 kaartbeelden weer van een uitsnede voor 1832 (kadaster) en 1900 (Bonne en HGN). 

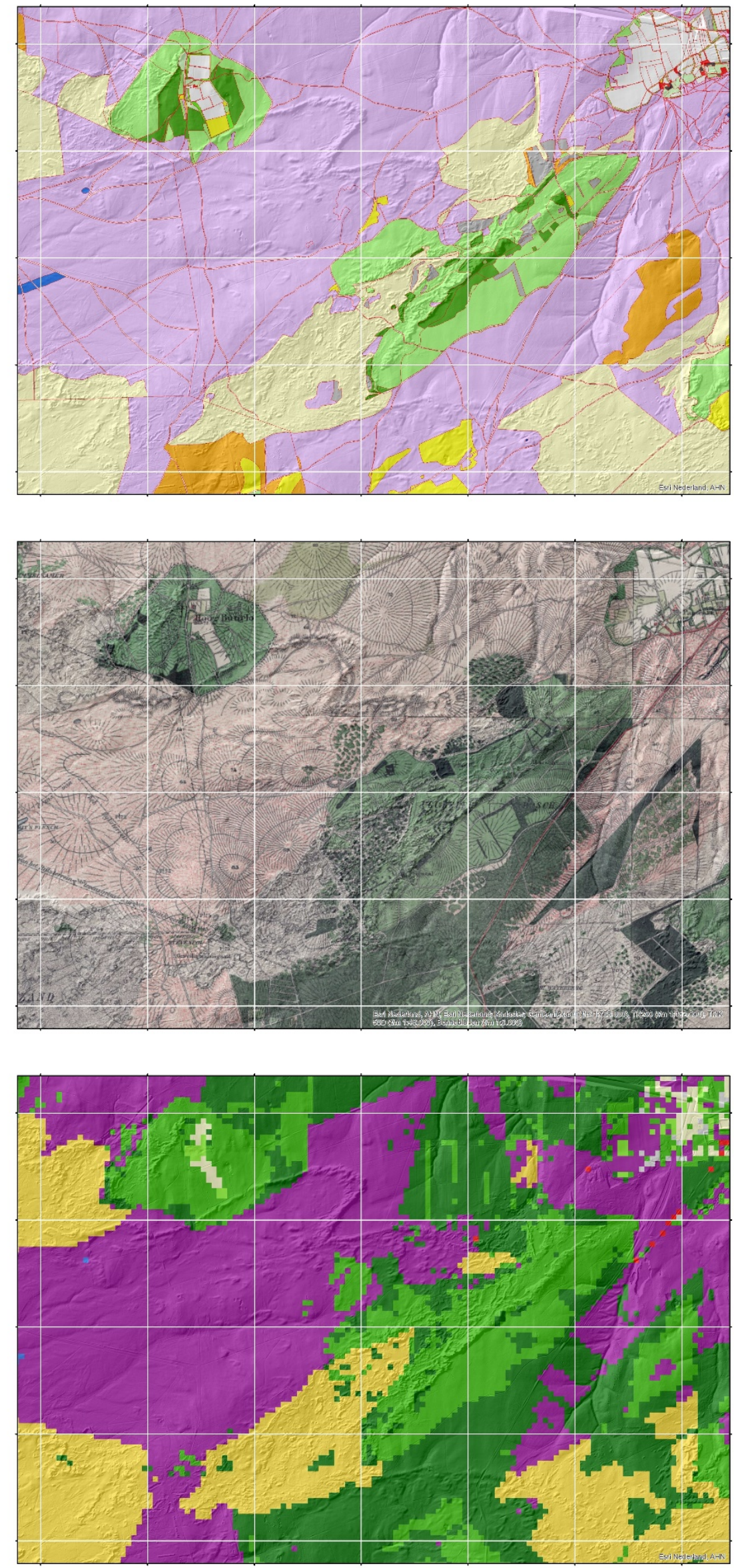

Figuur 5.1 Uitsneden van de kadastrale kaart 1832 (boven), Bonne-kaart 1901 (midden) en HGN 1900 (onder) voor het gebied Ugchelse Bos - Hoog Buurlo op de Veluwe. Ondergrond: AHN hillshade. Overlay: $1 \times 1 \mathrm{~km}$ raster. 


\subsection{Bestanden (afgeleid van) historisch kaartmateriaal}

Bij wijze van voorbeeld van het gebruik van het kadastrale materiaal is in Figuur 5.2 de verdeling van landgebruik over fysisch-geografische series opgenomen binnen het Natura 2000-gebied Veluwe. Hieruit blijkt dat niet alleen vrijwel alle bos in het begin van de $19^{\text {de }}$ eeuw was gelegen op lemig stuwwalmateriaal (= habitattype 9120 Beuken-eikenbossen), maar dat dit ook geldt voor heide 1 . Zie Bijlsma et al. (2008, Figuur 4.2) voor de relatie van markenbossen met moderpodzolgronden en leemgronden en Clerkx \& Bijlsma (2003) voor de interpretatie van heide 1 als 'heide met struiken' (gedegradeerd bos). Op de Veluwe kwam weinig bos voor met zeer goede kwaliteit (klassen 1-3) en dit lag vrijwel uitsluitend op lemige stuwwallen. Bos klasse 4 en 5, met de minste kwaliteit, kwam ook voor op leemarme stuwwallen en op landduinen en forten in het stuifzandlandschap (= habitattype 9190 Oude eikenbossen). Heide klasse 3 is sterk geconcentreerd op leemarme series (dekzanden, stuwwallen, puinwaaiers) en zand is uiteraard vrijwel beperkt tot de stuifzand-sectie. Beoordeeld aan absolute oppervlakten, was de Veluwe in het begin van de 19 de eeuw vooral een heide klasse 3- en zandlandschap, beide met een wettelijk minimumtarief van $\mathrm{f} 0,25$ per ha: het armste van het armste!
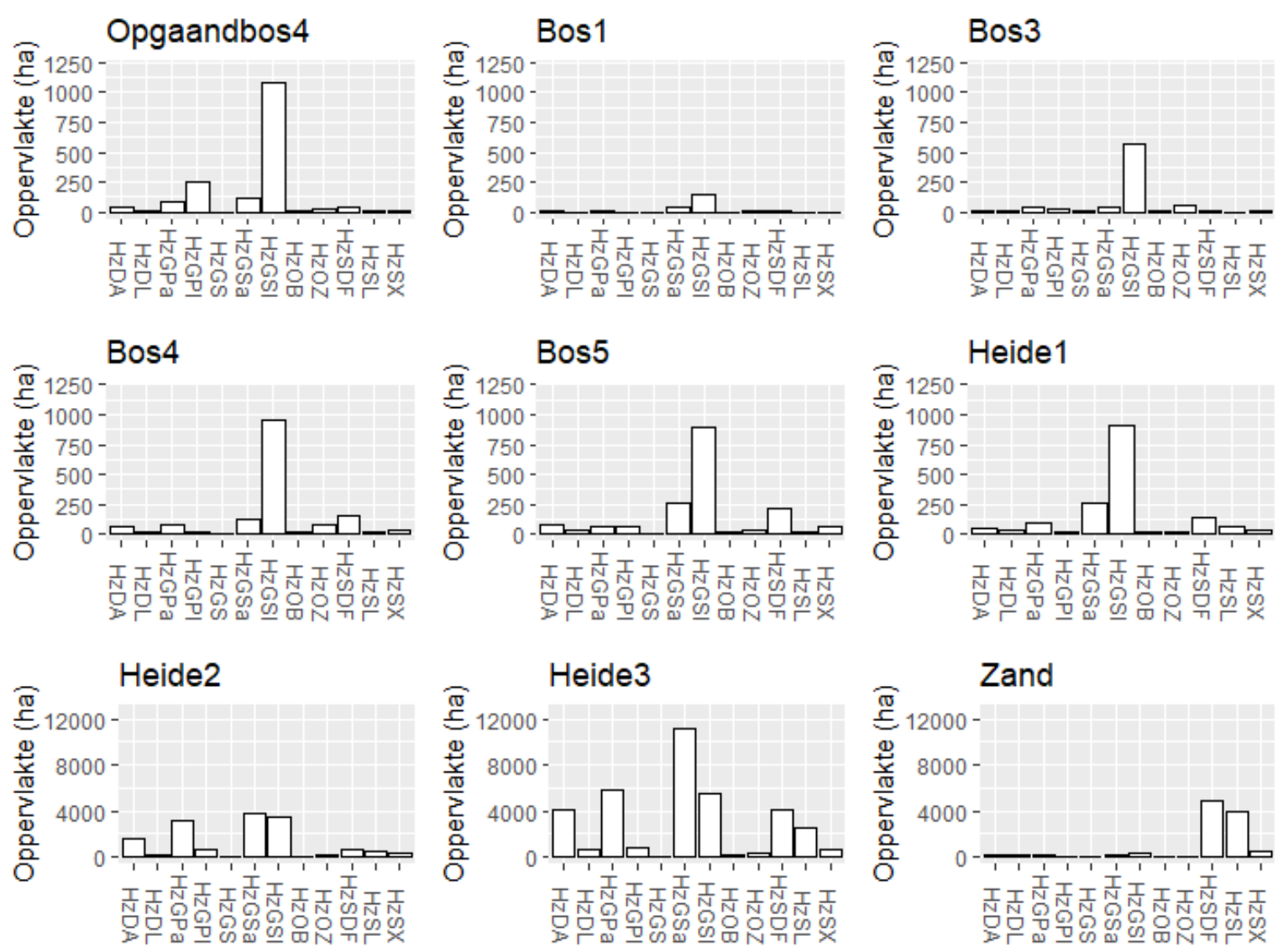

Figuur 5.2 Verdeling van categorieën landgebruik bos, heide en zand in 1832 over fysischgeografische series binnen het Natura 2000-gebied Veluwe. Zie Figuur 4.2 voor de codering van FGseries. Merk op dat de figuren in de onderste rij (heide 2, heide 3 en zand) een afwijkend bereik hebben ten opzichte van de overige deelfiguren. 


\section{Literatuur}

Angelstam, P. \& T. Kuuluvainen. 2005. Boreal forest disturbance regimes, successional dynamics and landscape structures - a European perspective. Ecological Bulletins 51: 117-136.

Bijlsma, R.J., 2002. Bosrelicten op de Veluwe. Een historisch-ecologische beschrijving. Alterrarapport 647, Wageningen.

Bijlsma, R.J., J.A.M. Janssen, R. Haveman, R.W. de Waal \& E.J. Weeda, 2008. Natura 2000 habitattypen in Gelderland. Alterra-rapport 1769, Wageningen.

Bijlsma, R.J., J. den Ouden \& H.N. Siebel, 2009. Oude eikenbossen: nieuwe inzichten en kansen voor het beheer. De Levende Natuur 110(2): 77-82.

Bijlsma, R.J., R.W. de Waal \& A.F.M. ten Hoedt, 2013. Ecological qualities emerging from nonintervention management of heathlands. In W.H. Diemont, H. Siepel \& N.R. Webb (eds.), Economy and ecology of heathlands. KNNV Publishing, Zeist; Chapter 12.

Bijlsma, R.J., J.A.M. Janssen, E.J. Weeda \& J.H.J. Schaminée, 2014. Gunstige referentiewaarden voor oppervlakte en verspreidingsgebied van Natura 2000-habitattypen in Nederland. WOt-rapport 125, Wageningen.

Bijlsma, R.J. \& J.A.M. Janssen, 2014. Structuur en functie van habitattypen. Onderdeel van de documentatie van de Habitatrichtlijn artikel 17-rapportage 2013. WOt-technical report 33. Wettelijke Onderzoekstaken Natuur \& Milieu, Wageningen.

Bijlsma, R.J., J.A.M. Janssen, E.J. Weeda \& A.J. Griffioen, 2015. Vegetatie-, beheer- en habitattypen van Het Nationale Park De Hoge Veluwe in 2014. Alterra rapport 2616, Wageningen.

Bijlsma, R.J., A.J.M. Jansen, J.A.M. Janssen, G.J. Maas, M. Pleijte, P.C. Schipper \& H.E. Wondergem, 2017. Kansen voor meer natuurlijkheid in Natura 2000-gebieden. Landschap 34 (3): 144 - 153.

Bijlsma, R.J., 2018. Nieuwe ecologische inzichten uit het oudste kadaster (van 1832). Symposium HisGIS Gelderland 30 mei 2018. Gelders Archief, Arnhem

Bijlsma, R.J., E. Agrillo, F. Attorre, L. Boitani, A. Brunner, P. Evans, R. Foppen, S. Gubbay, J.A.M. Janssen, A. van Kleunen, W. Langhout, R. Noordhuis, M. Pacifici, I. Ramírez, C. Rondinini, M. van Roomen, H. Siepel \& H.V. Winter. 2019a. Defining and applying the concept of Favourable Reference Values for species and habitats under the EU Birds and Habitats Directives. Technical report. Wageningen Environmental Research report 2928, Wageningen.

Bijlsma, R.J., E. Agrillo, F. Attorre, L. Boitani, A. Brunner, P. Evans, R. Foppen, S. Gubbay, J.A.M. Janssen, A. van Kleunen, W. Langhout, M. Pacifici, I. Ramírez, C. Rondinini, M. van Roomen, H. Siepel, C.A.M. van Swaaij \& H.V. Winter. 2019b. Defining and applying the concept of Favourable Reference Values for species and habitats under the EU Birds and Habitats Directives: examples of setting favourable reference values. Wageningen Environmental Research report 2929, Wageningen

Bijlsma, R.J., S.P.J. van Delft \& J.J. de Jong, 2020. Natura 2000-habitattypen droge bossen in Drenthe. Onderzoek naar de kwaliteit van bodem, vegetatie en stamhout van eik in oude bossen. WENR-rapport 3029. Wageningen.

Bonten, L.T.C., R.J. Bijlsma, S.P.J. van Delft, J.J. de Jong, J.H. Spijker \& W. de Vries, 2015. Houtoogst en bodemvruchtbaarheid. Een modelstudie naar duurzaamheid van houtoogst op Nederlandse bosgroeiplaatsen. Alterra-rapport 2618, Wageningen.

Bos-Groenendijk, G.I. \& C.A.M. van Swaay, 2018. Standaard Data Formulieren Natura 2000-gebieden; Aanvullingen vanwege wijzigingen in Natura 2000-aanwijzingsbesluiten. Wageningen, Wettelijke Onderzoekstaken Natuur \& Milieu, WUR. WOt-technical report 114.

Bücking, W., 2003. Are there threshold numbers for protected forests? Journal of Environmental Management 67: 37-45.

Busing, R.T. \& P.S. White, 1993. Effects of area on old-growth forest attributes: implications for the equilibrium landscape concept. Landscape Ecology 8(2): 119-126.

Clerkx, A.P.P.M. \& R.J. Bijlsma, 2003. Veluwse heide blijkt open boslandschap na ecologische interpretatie van het kadastrale archief van 1832. De Levende Natuur 104(4): 148-155. 
Cornelis, J., M. Hermy, B. Roelandt, L. De Keersemaeker \& K. Vandekerkhove, 2009.

Bosplantengemeenschappen in Vlaanderen: een typologie van bossen gebaseerd op de kruidlaag. Mededelingen van het INBO 5. Brussel.

De Bakker, H. \& J. Schelling, 1989. Systeem van bodemclassificatie voor Nederland; de hogere niveaus. Wageningen, Pudoc.

Den Ouden, J., P. Copini \& U.G.W. Sass-Klaassen, 2009. Een nieuwe kijk op oude eiken. De Levende Natuur 110(2): 83-87.

Den Ouden, J., D.R. Lammertsma \& H.A.H. Jansman, 2020. Effecten van hoefdieren op Natura 2000boshabitattypen op de Veluwe. Rapport Wageningen University, WENR-rapport 3013. Wageningen.

De Vries, W., M.J. Weijters, J.J. de Jong, S.P.J. van Delft, J. Bloem, A. van den Burg, G.A. van Duinen, E. Verbaarschot \& R. Bobbink, 2019. Verzuring van loofbossen op droge zandgronden en herstelmogelijkheden door steenmeeltoediening. Rapport OBN229-DZ. Vereniging van Bos- en Natuurterreineigenaren (VBNE), Driebergen.

Goutbeek, A., 2015. Eikenhakhout langs de Vecht. Ambacht rond Dalfsen in de negentiende eeuw. Matrijs, Utrecht.

Hahn, K., J. Emborg, L. Vesterdal, S. Christensen, R.H.W. Bradshaw, K. Raulund-Rasmussen \& J.B. Larsen, 2007. Natural forest stand dynamics in time and space - synthesis of research in Suserup Skov, Denmark and perspectives for forest management. Ecological Bulletins 52: 183-194.

Hermy, M. \& R.J. Bijlsma. 2010. Bosbeheer en biodiversiteit. In J. den Ouden, B. Muys, F. Mohren \& K. Verheyen (red.), Bosecologie en bosbeheer. Acco Leuven; 493-501.

Janssen, J.A.M., E.J. Weeda, P.C. Schipper, R.J. Bijlsma, J.H.J. Schaminée, G.H.P. Arts, C.M. Deerenberg, O.G. Bos \& R.G. Jak, 2014. Habitattypen in Natura 2000-gebieden. Beoordeling van oppervlakte, representativiteit en behoudsstatus in de Standard Data Forms. WOt-technical report 8 , Wageningen.

Janssen, J.A.M. (red.), R.J. Bijlsma (red.), G.H.P. Arts, M. Baptist, S.M. Hennekens, B. de Knegt, T. van der Meij, J.H.J. Schaminée, A.J. van Strien, S. Wijnhoven \& T.J.W. Ysebaert, 2020. Habitatrichtlijnrapportage 2019: Annex D Habitattypen. Achtergronddocument. WOT technical report nr. 171, Wettelijke Onderzoekstaak Natuur \& Milieu, Wageningen.

Jongmans, A.G., M.W. van den Berg, M.P.W. Sonneveld, G.J.W.C. Peek \& R.M. van den Berg Saparoea, 2012. Landschappen van Nederland; Geologie, bodem en Landgebruik. Wageningen, Wageningen Academic Publishers.

Jungerius, P.D. \& M.J.P.M. Riksen, 2010. Contribution of laser altimetry images to the geomorphology of the Late Holocene inland drift sands of the European Sand Belt. Baltica 23(1): 59-70.

Kadaster, 2014. Aan de slag in de kadastrale archieven. Een handleiding voor de particuliere onderzoeker. Dienst voor het kadaster en de openbare registers, Apeldoorn.

Kemmers, R.H., S.P.J. van Delft, M.C. van Riel, P.W.F.M. Hommel, A.J.M. Jansen, B. Klaver, R. Loeb, J. Runhaar \& H. Smeenge, 2011. Landschapsleutel; Leidraad voor natuurontwikkeling. Wageningen, Alterra, onderdeel van Wageningen UR. Alterra-rapport 2140. 83 p.

Knol, W.C., H. Kramer \& H. Gijsbertse, 2004. Historisch Grondgebruik Nederland: een landelijke reconstructie van het grondgebruik rond 1900. Alterra-rapport 573. Wageningen.

Koomen, A.J.M. \& G.J. Maas, 2009. Zoekgebieden voor heide, stuifzand en heischraal grasland op de Veluwe (Natura 2000). Inventarisatie van geschikte gebieden voor uitbreiding en verbinding. Alterra-rapport 1800. Wageningen.

Koomen, A., G. Maas \& P. Jungerius, 2004. Het stuifzandlandschap als natuurverschijnsel. Landschap 21(3): 159-168.

Koop, H. \& S. van der Werf, 1995. Natuurlijke bosgemeenschappen A-locaties en boscomplexen. Achtergronddocument bij de Ecosysteemvisie Bos. IBN-rapport 162. Wageningen.

Koster, E.A., 1968. De invloed van markebossen op de vorming van zeer hoge stuifzandruggen ('randwallen') op de Veluwe. Boor en Spade 16: 66-73.

Koster, E.A., 1978. De stuifzanden van de Veluwe: een fysisch-geografische studie. Ph.D. thesis, Universiteit van Amsterdam.

Kramer, H. \& G. van Dorland, 2009. Historisch Grondgebruik Naderland 1990: een landelijke reconstructie van het grondgebruik rond 1990. Alterra-rapport 1327 . Wageningen.

Lommaert, L., D. Adriaens \& M. Pollet (red.), 2020. Criteria voor de beoordeling van de lokale staat van instandhouding van de Habitatrichtlijnsoorten in Vlaanderen. Versie 2.0. INBO 
Maas, G.J., M. van der Meij, S.P.J. van Delft \& A.H. Heidema, 2019. Toelichting bij de legenda Geomorfologische kaart van Nederland 1:50 000 (2019). http://legendageomorfologie.wur.nl/. Wageningen, Wageningen Environmental Research.

Menke, H., H. Renes, G. Smid \& P. Stork, 2007. Veluwse beken en sprengen. Een uniek landschap. Matrijs, Utrecht.

Müller, J. \& R. Bütler, 2010. A review of habitat thresholds for dead wood: a baseline for management recommendations in European forests. Eur.J.Forest Res. 129:981-992.

Nijssen, M., R. Versluijs, L. van den Bremer \& H. Sierdsema, 2019. Soortenherstelprogramma beheerplan Natura 2000 Veluwe: Ecologisch profiel en analyse knelpunten vogelsoorten. Sovonrapport 2019/76. Stichting Bargerveen \& Sovon Vogelonderzoek Nederland, Nijmegen.

Noss, R.F., 1990. Indicators for monitoring biodiversity: a hierarchical approach. Conservation Biology 4: 355-364.

Oosterlynck, P., S. De Saeger, A. Leyssen, S. Provoost, A. Thomaes, B. Vandevoorde, J. Wouters \& D. Paelinckx, 2020. Criteria voor de beoordeling van de lokale staat van instandhouding van de Natura 2000 habitattypen in Vlaanderen. Basisinstrumentarium ter bepaling van de mate van instandhouding van habitatlocaties a.d.h.v. indicatoren voor structuur, vegetatieontwikkeling, verstoringsindicatoren en ruimtelijke samenhang. Versie 3.0. INBO.R.2018.14061248.

Ottburg, F.G.W.A. \& J.A.M. Janssen, 2014. Habitatrichtlijnsoorten in Natura 2000-gebieden. Beoordeling van populatie, leefgebied en isolatie in de Standard Data Forms (SDFs). Wettelijke Onderzoekstaken Natuur \& Milieu. WOt-technical report 9, Wageningen.

Ottburg, F.G.W.A. \& C.A.M. van Swaaij (red.), 2014. Gunstige referentiewaarden voor populatieomvang en verspreidingsgebied van soorten van bijlage II, IV en $V$ van de Habitatrichtlijn. WOt-rapport 124, Wageningen.

Parviainen, J., 2005. Virgin and natural forests in the temperate zone of Europe. For.Snow Landsc. Res. 79(1/2): 9-18.

Poiani, K.A., B.D. Richter, M.G. Anderson \& H.E. Richter, 2000. Biodiversity conservation at multiple scales: Functional sites, landscapes, and networks. BioScience 50(2): 133-146.

Pouwels, R., M.J.S.M. Reijnen, J.T.R. Kalkhoven \& J. Dirksen, 2002a. Ecoprofielen voor soortanalyses van ruimtelijke samenhang met $\mathrm{LARCH}$. Alterra-rapport 493. Wageningen.

Pouwels, R., R. Jochem, M.J.S.M. Reijnen, S.R. Hensen \& J.G.M. van der Greft, 2002b. LARCH voor ruimtelijke ecologische beoordelingen van landschappen. Alterra-rapport 492. Wageningen.

Pouwels, R., M.J.S.M. Reijnen, M.H.C. van Adrichem \& H. Kuipers, 2007. Ruimtelijke condities voor VHR-soorten. WOt Natuur \& Milieu, Werkdocument 57. Wageningen.

Pouwels, R., J.G.M. van der Greft, M.H.C. van Adrichem, H. Kuipers, R. Jochem, M.J.S.M. Reijnen, 2008. LARCH Status A. WOt werkdocument 107. Wettelijke Onderzoekstaken Natuur \& Milieu, Wageningen.

Schmidt, A.M., C.A.M. van Turnhout, T. Wolterbeek, R.J. Bijlsma, L. Soldaat \& C.A.M. van Swaaij, 2017. Naar een samenhangend monitoring- en beoordelingssysteem voor het natuurbeleid. WENR rapport 2758, Wageningen.

Schmidt, P. \& G. van Duinhoven (red.), 2016. Een nieuwe toekomstvisie voor de Veluwezoom. Vakblad Natuur Bos Landschap maart 2016: 23-25.

Siepel, H., A. Cliquet, L.C. Vreugdenhil \& R.J. Bijlsma, 2017. Wat kunnen we doen, wat moeten we laten? Herstel van het droog zandlandschap. Landschap 2017/2: 87-93.

Sierdsema, H., J. van Diermen, B. Aarts, L. van den Bremer \& A. van Kleunen, 2008. Factsheets van broedvogels in de Natura 2000-gebieden van Gelderland. SOVON onderzoeksrapport 2008/14. SOVON, Beek-Ubbergen.

Sierdsema, H., A. van Kleunen, L. van den Bremer, L. Sparrius, J. Smit, A. Gmelig Meyling, T. Termaat, J. Kranenbarg, H. Hollander, R. Zollinger \& J. Stahl, 2016. Leefgebiedenkaarten van de Natura 2000-gebieden en PAS-gebieden. Sovon-rapport 2016/21. Sovon Vogelonderzoek Nederland, Nijmegen.

Sierdsema, H., H. ten Holt, S. Martens, M. Nijssen \& P. Verburg, 2020a. Natuurbeheer- en zoneringsmaatregelen voor zeven aangewezen vogelsoorten in Natura 2000-gebied Veluwe. Bouwstenen Soortenherstel Beheerplan Natura 2000 Veluwe. Hoofdrapport. Sovon-rapport 2020/29. Sovon Vogelonderzoek Nederland, Nijmegen.

Sierdsema, H., H. ten Holt, S. Martens, M. Nijssen \& P. Verburg, 2020b. Natuurbeheer- en zoneringsmaatregelen voor zeven aangewezen vogelsoorten in Natura 2000-gebied Veluwe. 
Bouwstenen Soortenherstel Beheerplan Natura 2000 Veluwe. Achtergrondrapport. Sovon-rapport 2020/32. Sovon Vogelonderzoek Nederland, Nijmegen.

Spek, Th., 1993. Milieudynamiek en locatiekeuze op het Drents Plateau (3400 v.Chr. - 1850 na Chr.) In J.N.H. Elerie, S.W. Jager \& Th. Spek, Landschapsgeschiedenis van De Strubben/Knipkorstbos. Archeologische en historisch-ecologische studies van een natuurgebied op de Hondsrug. Van Dijk \& Foorthuis REGIO-PRojekt Groningen; 171-232.

Spek, Th., 2004. Het Drentse esdorpenlandschap. Een historisch-geografische studie. Matrijs, Utrecht. Stortelder, A.H.F., P.W.F.M. Hommel, R.W. de Waal, K.W. van Dort, J.G. Vrielink \& R.J.A.M. Wolf, 1998. Broekbossen. Bosecosystemen van Nederland 1. KNNV Uitgeverij, Utrecht.

Ten Cate, J.A.M., A.F. van Holst, H. Kleijer \& J. Stolp, 1995. Handleiding bodemgeografisch onderzoek; Richtlijnen en voorschriften; Deel A: Bodem. Wageningen, SC-DLO. Technisch document 19A.

Vandekerkhove, K., 2019. Status and development of old-growth elements and biodiversity during secundary succession of unmanaged temperate forests. Ph.D. thesis, Ghent University.

Van Delft, B., R. de Waal, R. Kemmers, P. Mekkink \& J. Sevink, 2006. Field guide Humus Forms; Description and classification of humus forms for ecological applications. Alterra, Wageningen.

Van Delft, S.P.J., G.J. Maas \& R.W. de Waal, 2015. De Landschapsleutel OnLine 2015, http://landschapsleutel.wur.nl/. Wageningen, Alterra - WageningenUR.

Van Delft, B., 2020. Eenheden landschappelijke bodemkaart. Wageningen, WENR. Werkdocument.

Van den Burg, A., R.J. Bijlsma \& R. Bobbink, 2015. Arme bossen verdienen beter. OBN Deskundigenteam Droog zandlandschap. KNNV Publishing, Zeist.

Van der Molen, P.C., G.J. Baaijens, A. Grootjans \& A. Jansen, 2010. LESA. Landschapsecologische systeemanalyse. http://www.natura2000.nl/pages/landschapsecologische-systeemanalyselesa.aspx

Van der Weide, M., 2019. Toetsbare doelen \& monitoring Veluwezoom/Deelerwoud. SNL beheertype Zand- en kalklandschap. Natuurmonumenten.

Van der Werf, S., 1991. Bosgemeenschappen. Natuurbeheer in Nederland Deel 5. Pudoc Wageningen.

Van Diggelen, R., H. Bergsma, R.J. Bijlsma, R. Bobbink, A. van den Burg, J. Sevink, H.N. Siebel, H. Siepel, J. Vogels, W. de Vries \& M. Weijters, 2019. Steenmeel en natuurherstel: een gelukkige relatie of een risicovolle combinatie? Vakblad Natuur Bos Landschap 155: 20-23.

Van Jaarsveld, H., G.J. Reinds, A. van Hinsberg \& M. van Esbroek, 2010. Depositie van basische kationen in Nederland. PBL-rapport M00093/01/VZ.

Van Kleunen, A., M. van Roomen, L. van den Bremer, A.J.J. Lemaire, J-W. Vergeer \& E. van Winden, 2014. Ecologische gegevens van vogels voor Standaard Gegevensformulieren Vogelrichtlijngebieden. Wettelijke Onderzoekstaken Natuur \& Milieu. WOt-Technical report 2, Wageningen/ Sovon Vogelonderzoek Nederland. Sovon-rapport 24, Nijmegen.

Veldhorst, A.D.M., 1991. Het Nederlandse vroeg-19e-eeuwse kadaster als bron voor andersoortig onderzoek, een verkenning. Historisch-Geografisch Tijdschrift 9: 8-27.

Vermeersch, G., P. Adriaens, N. Boone \& M. Pollet (red.), 2020. Criteria voor de beoordeling van de lokale staat van instandhouding van de Vogelrichtlijnsoorten in Vlaanderen. Versie 2.0. INBO.

Weijters, M., R. Bobbink, E. Verbaarschot, B. van de Riet, J. Vogels, H. Bergsma \& H. Siepel, 2018. Herstel van heide door middel van slow release mineralengift - resultaten van 3 jaar steenmeelonderzoek. OBN222DZ. VBNE, Driebergen.

Wulf, M. 2003. Preference of plant species for woodlands with differing habitat continuities. Flora 198, 444-460.

Zollinger, R., M.F. Wallis de Vries, M. Reemer \& A. van Rijsewijk, 2008. Veluwse heide verbonden. Visie op hoe populaties van entomofauna en herpetofauna zijn te verbinden en te versterken binnen het Veluwse Natura 2000 gebied. VOFF-rapport 2007-10. Nijmegen. 


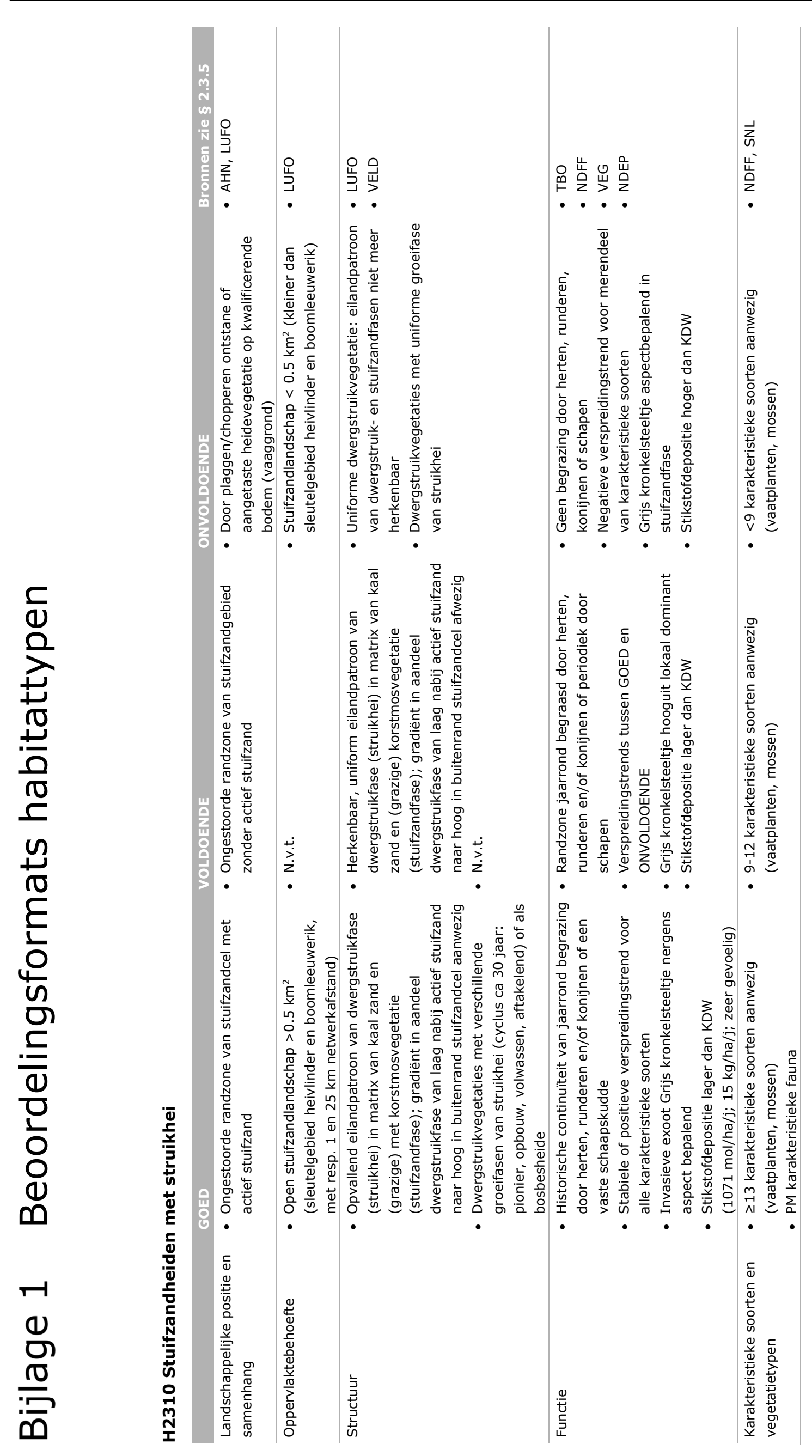




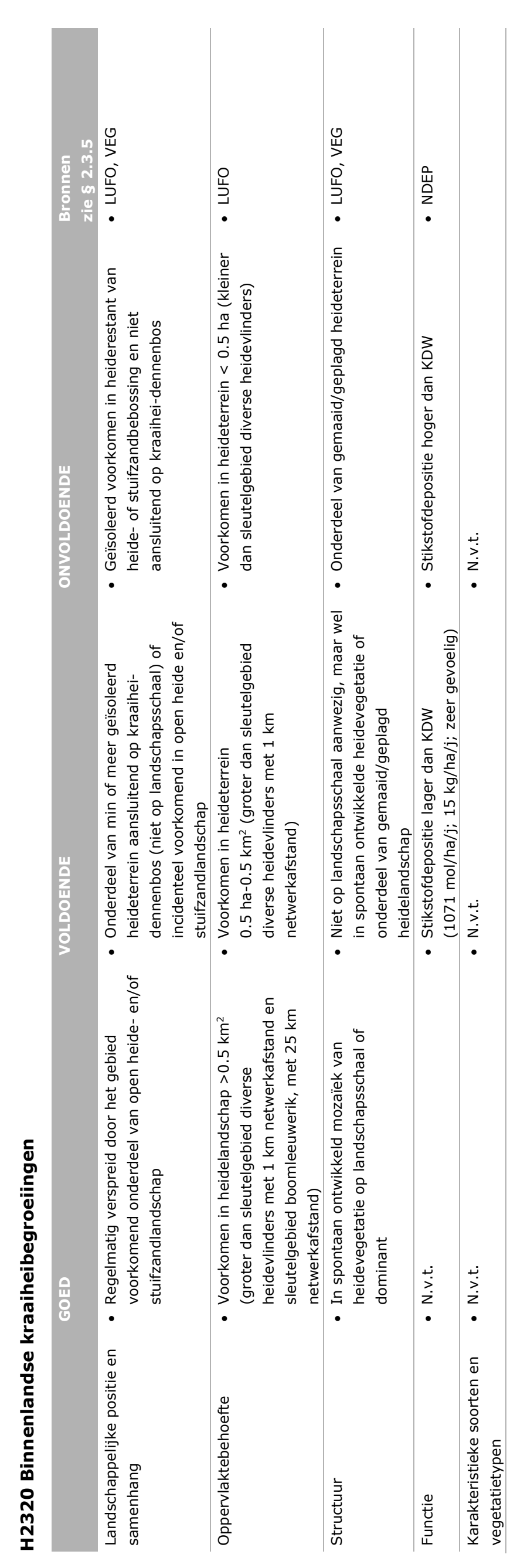

54 | Wageningen Environmental Research Rapport 3036 


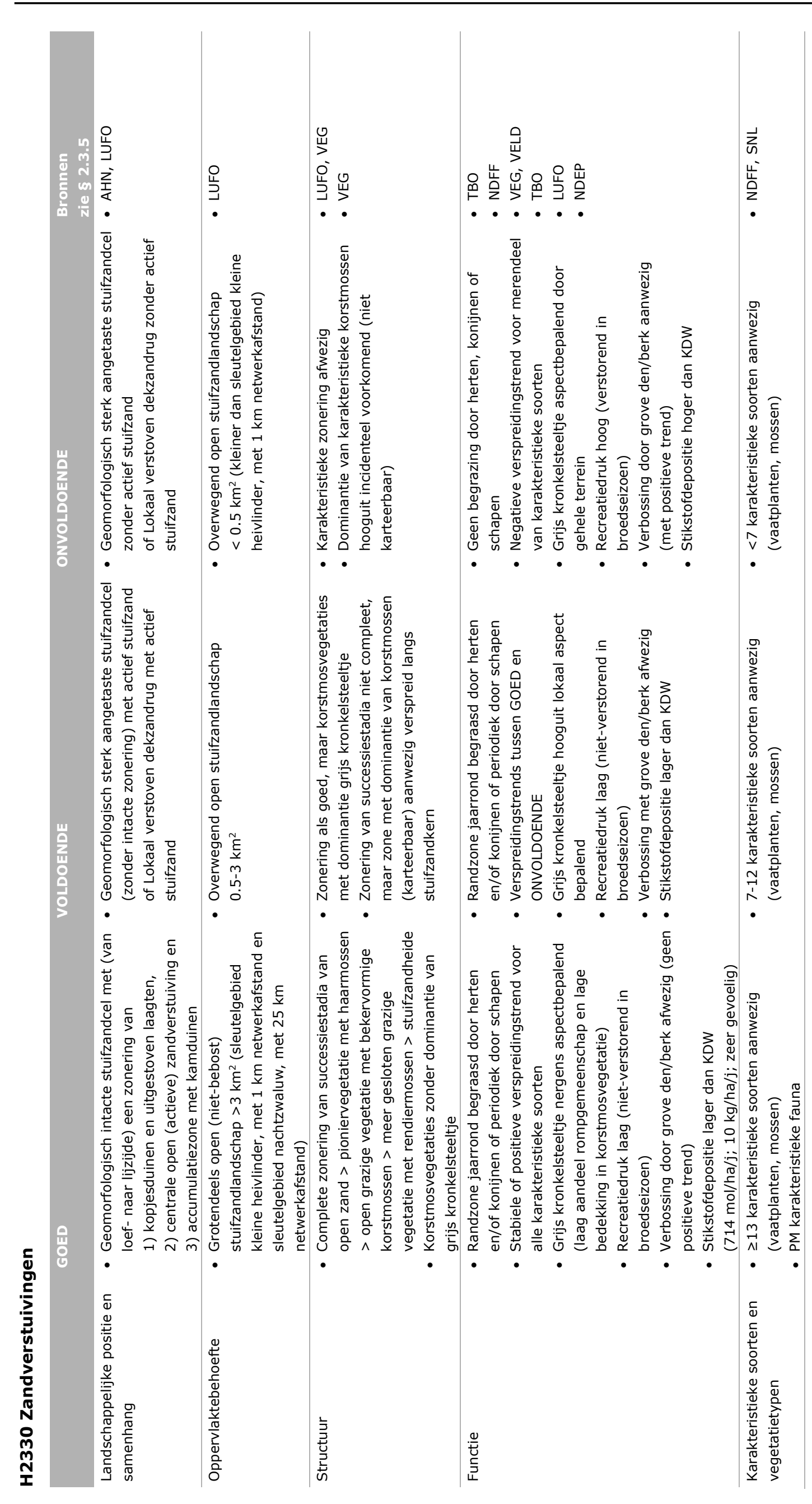




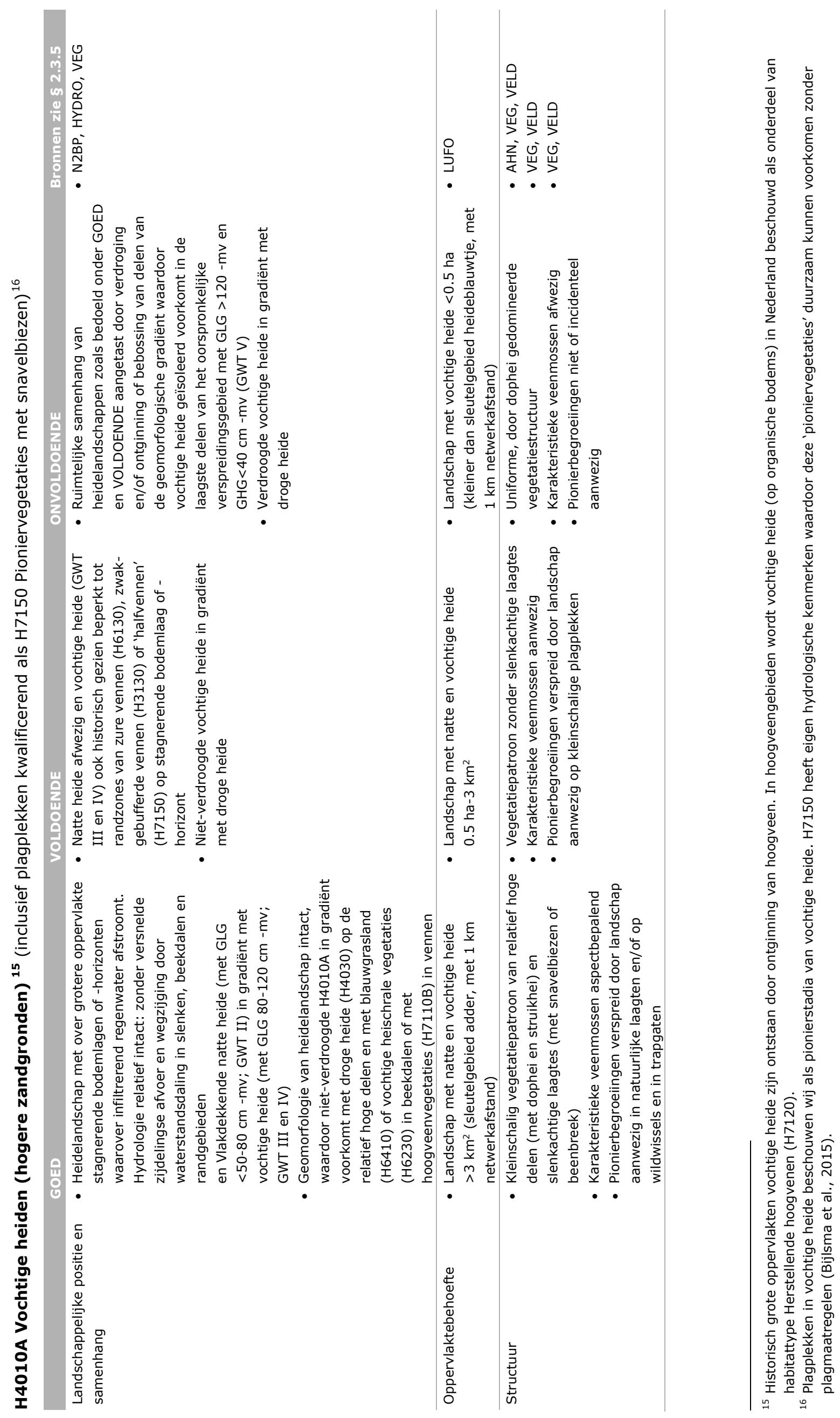

56 | Wageningen Environmental Research Rapport 3036 


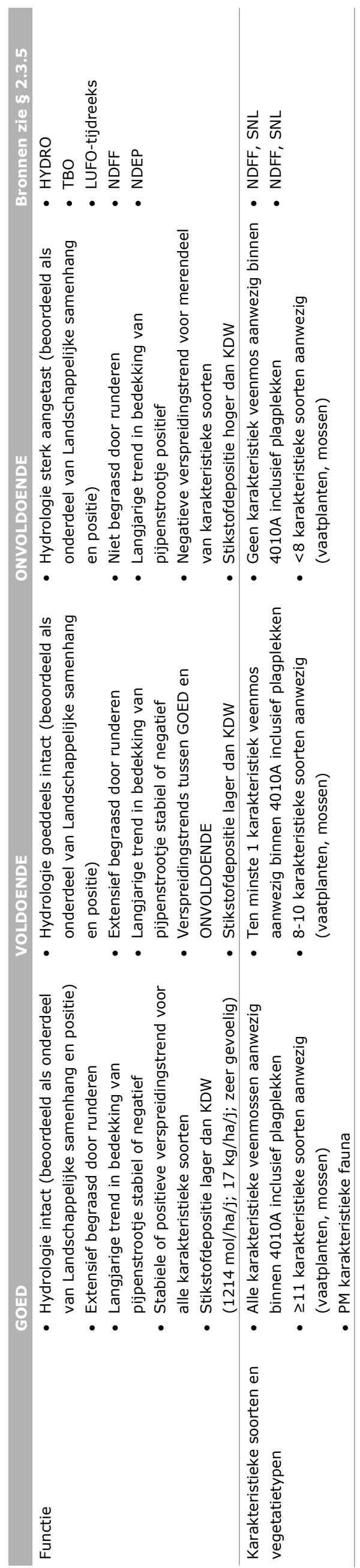




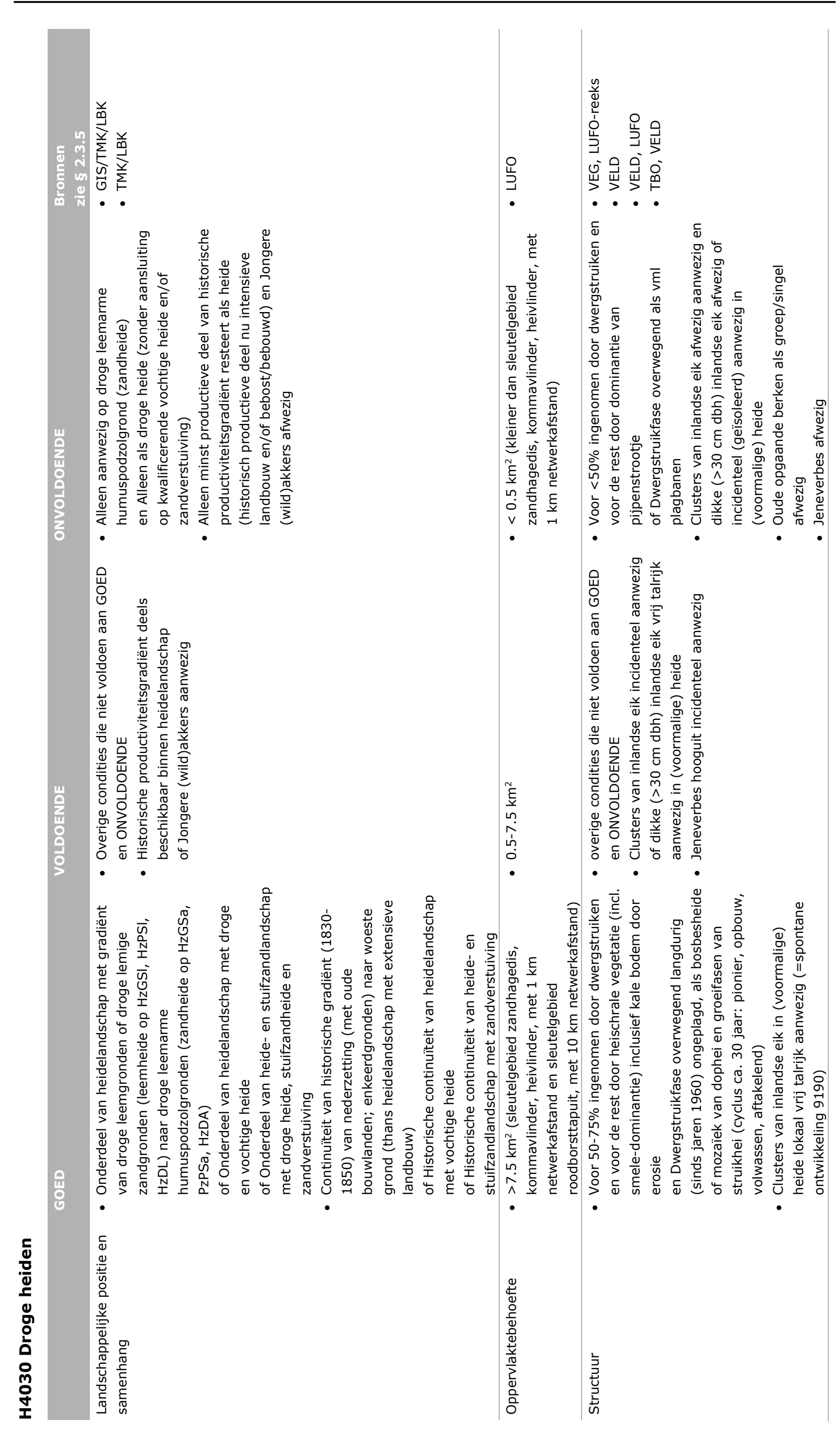

58 | Wageningen Environmental Research Rapport 3036 


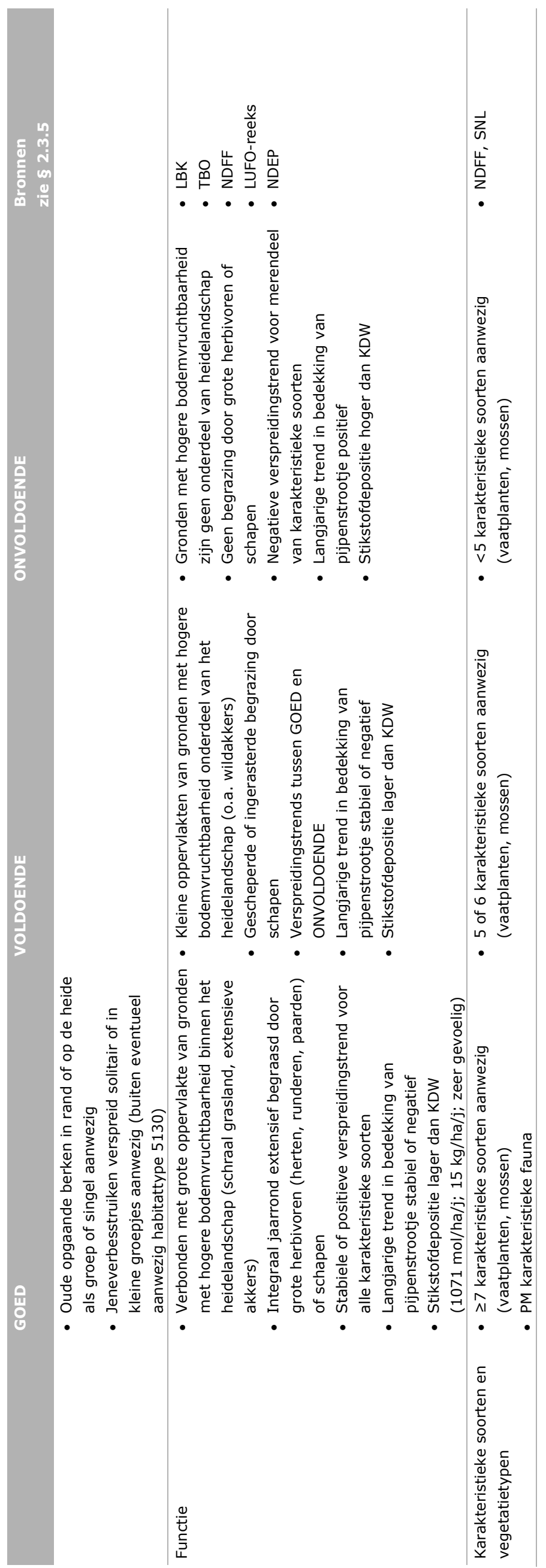




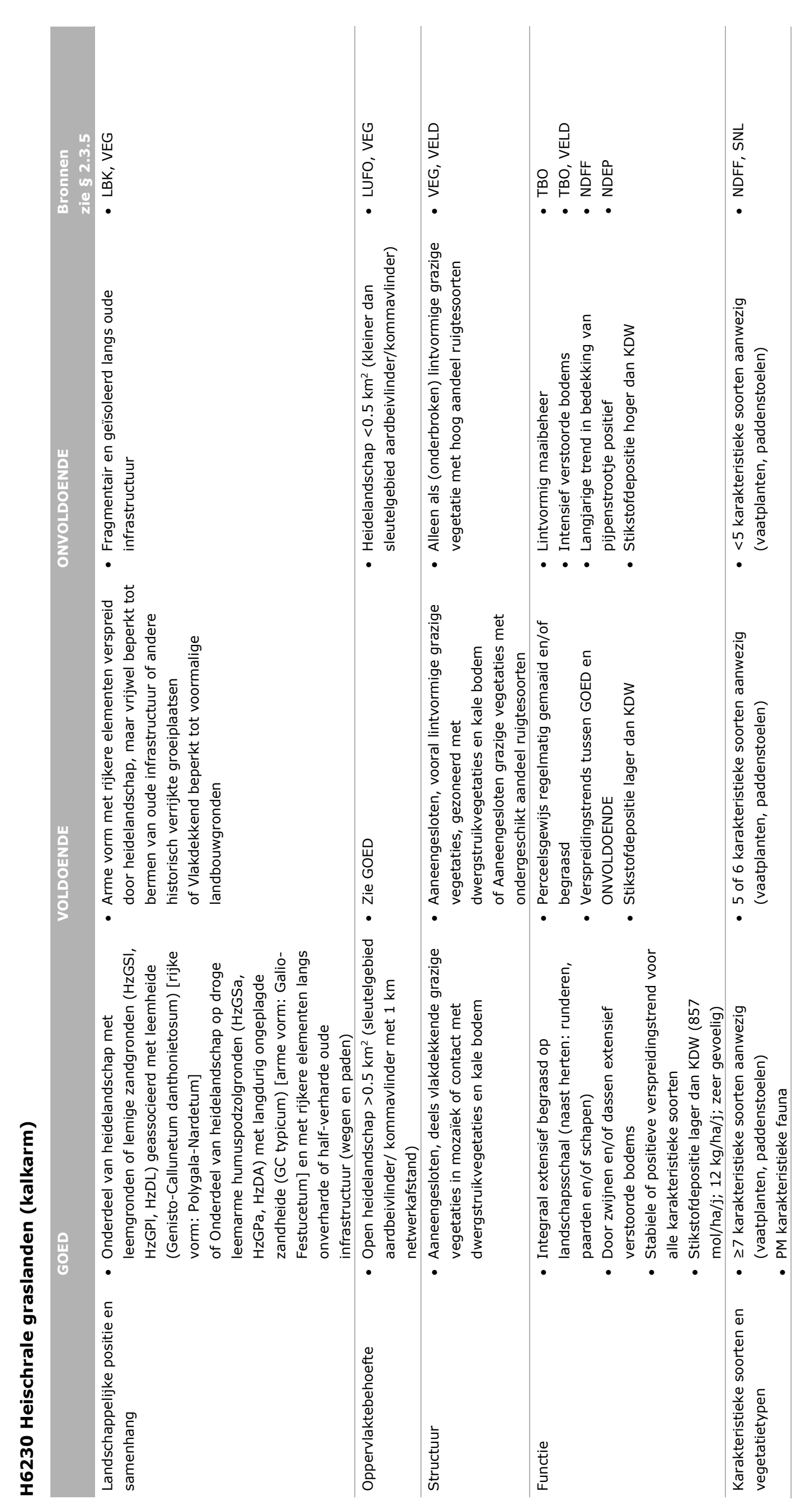




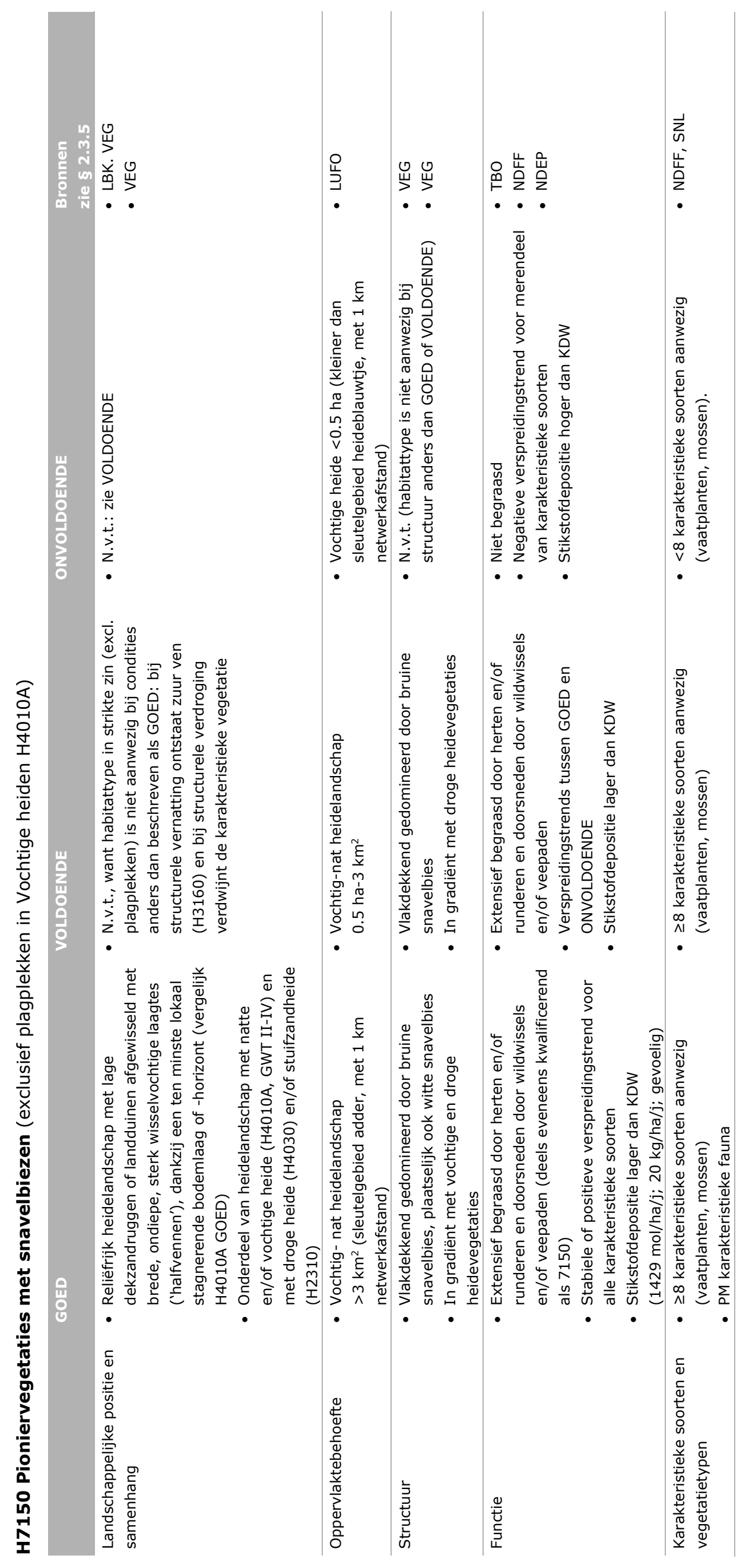


雚

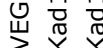

盖变交

...

京

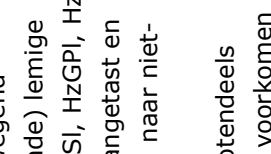

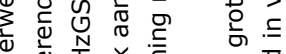

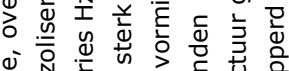

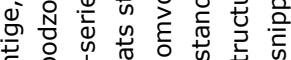

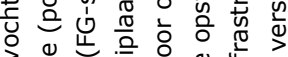

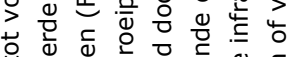

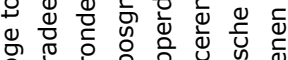

응 क्ष̃

оㅇํำ

定

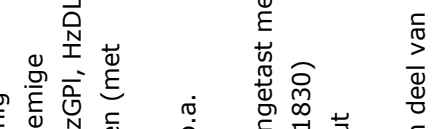

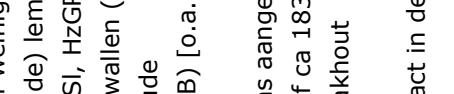

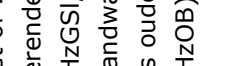

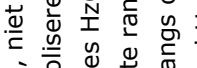

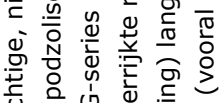

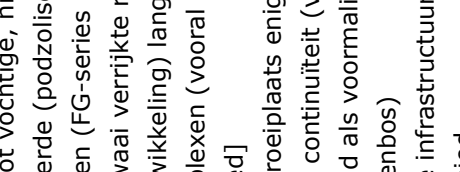

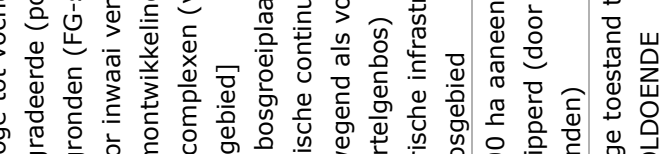

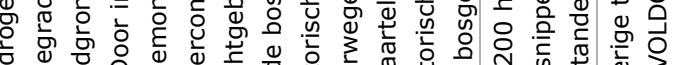

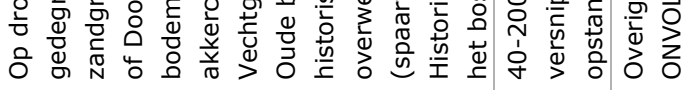

品㞻品

点㫐㫐

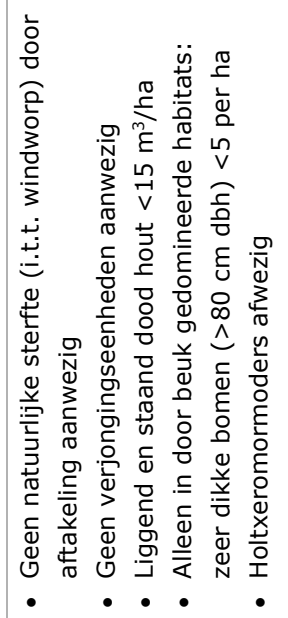

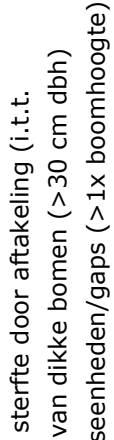

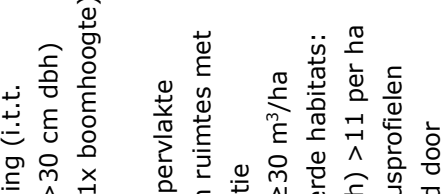

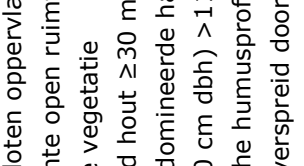

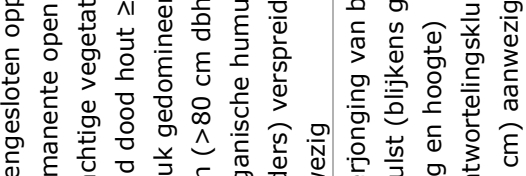

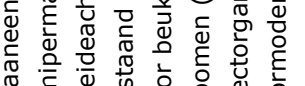

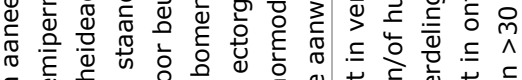

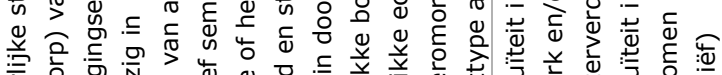

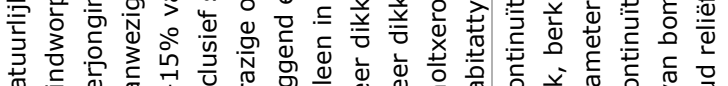

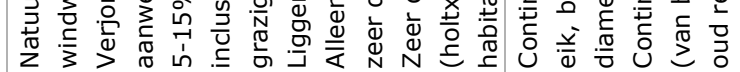
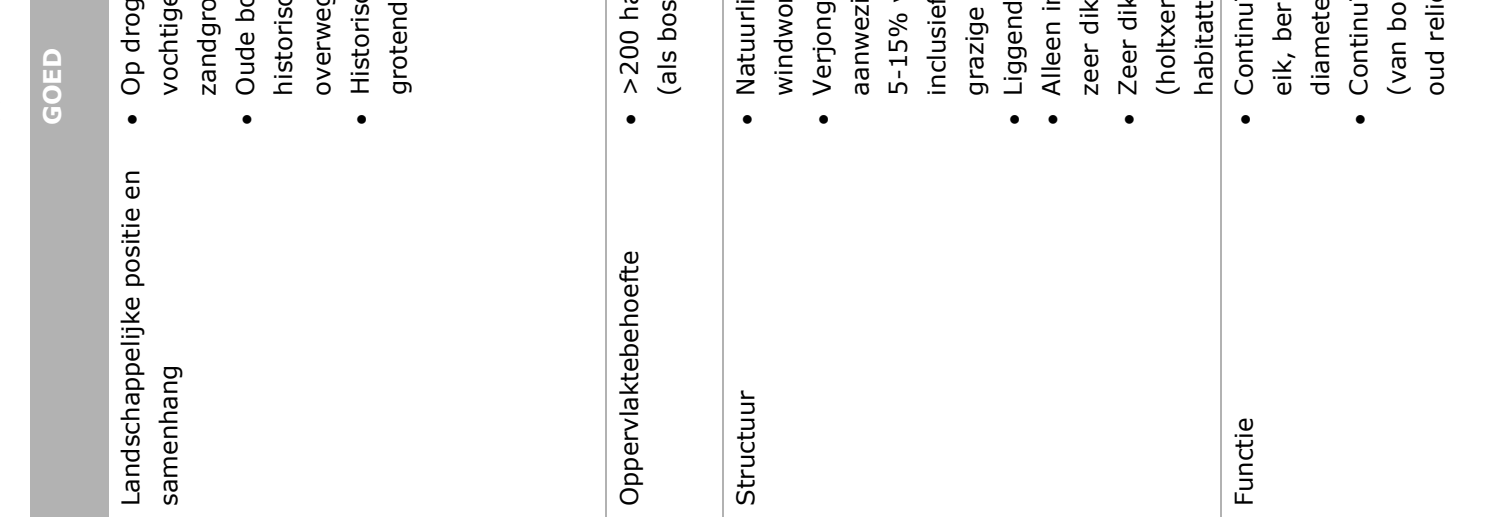


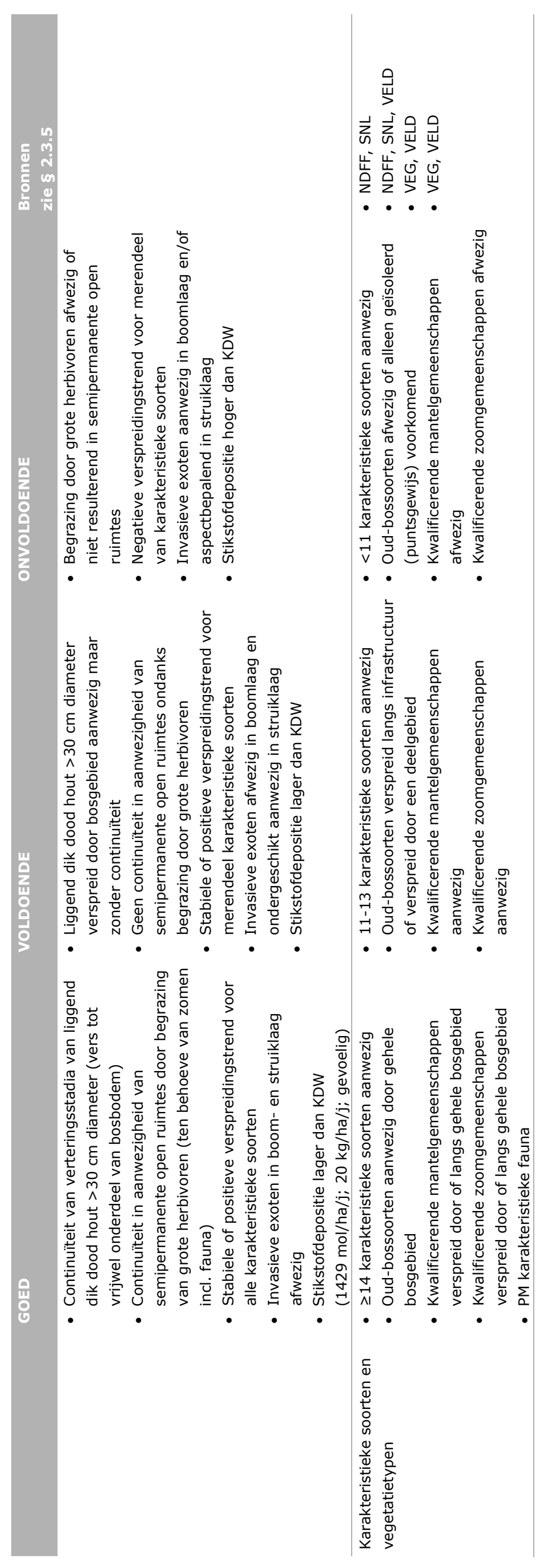

Wageningen Environmental Research Rapport 3036 | 63 


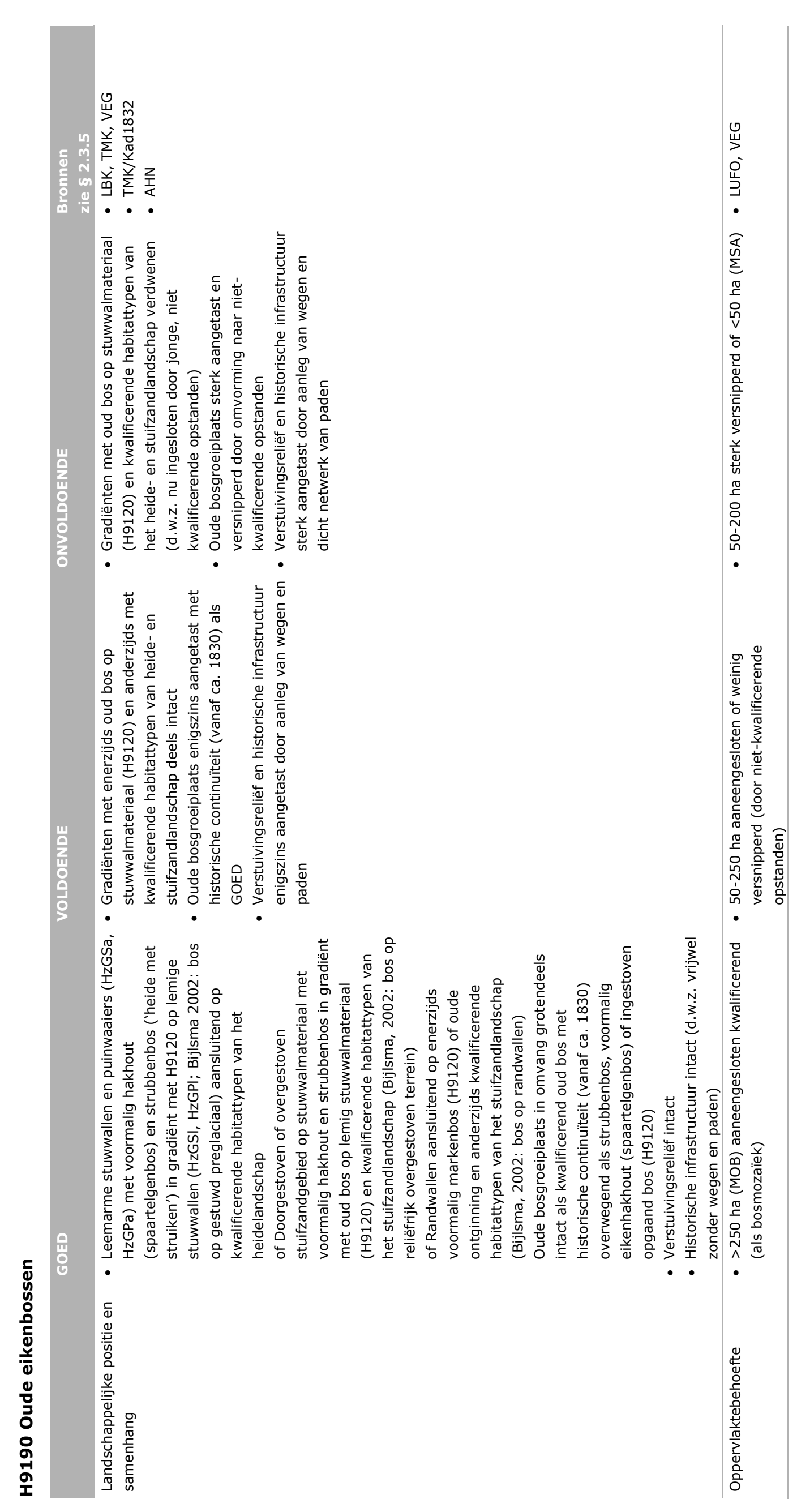

64 | Wageningen Environmental Research Rapport 3036 


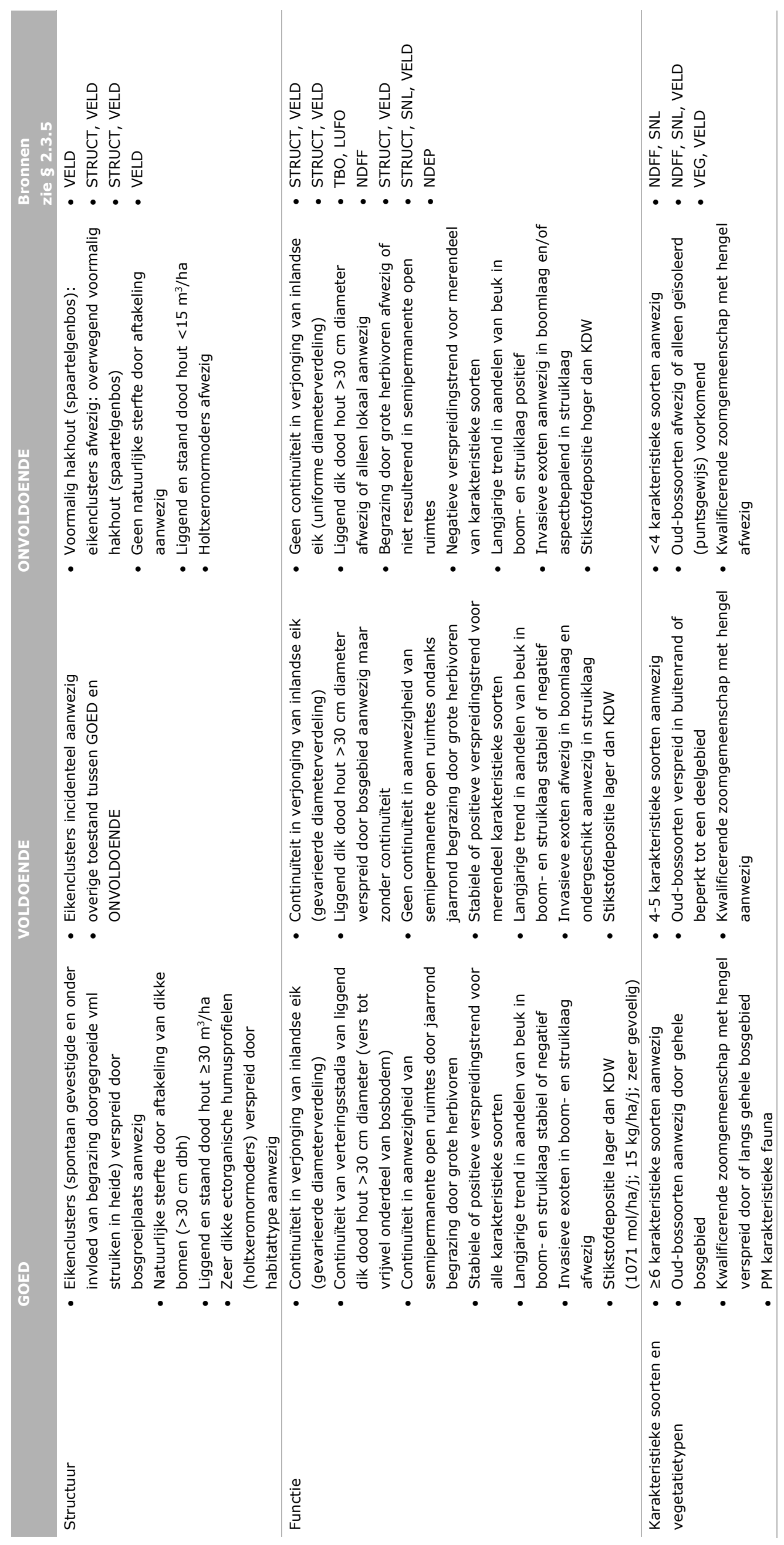




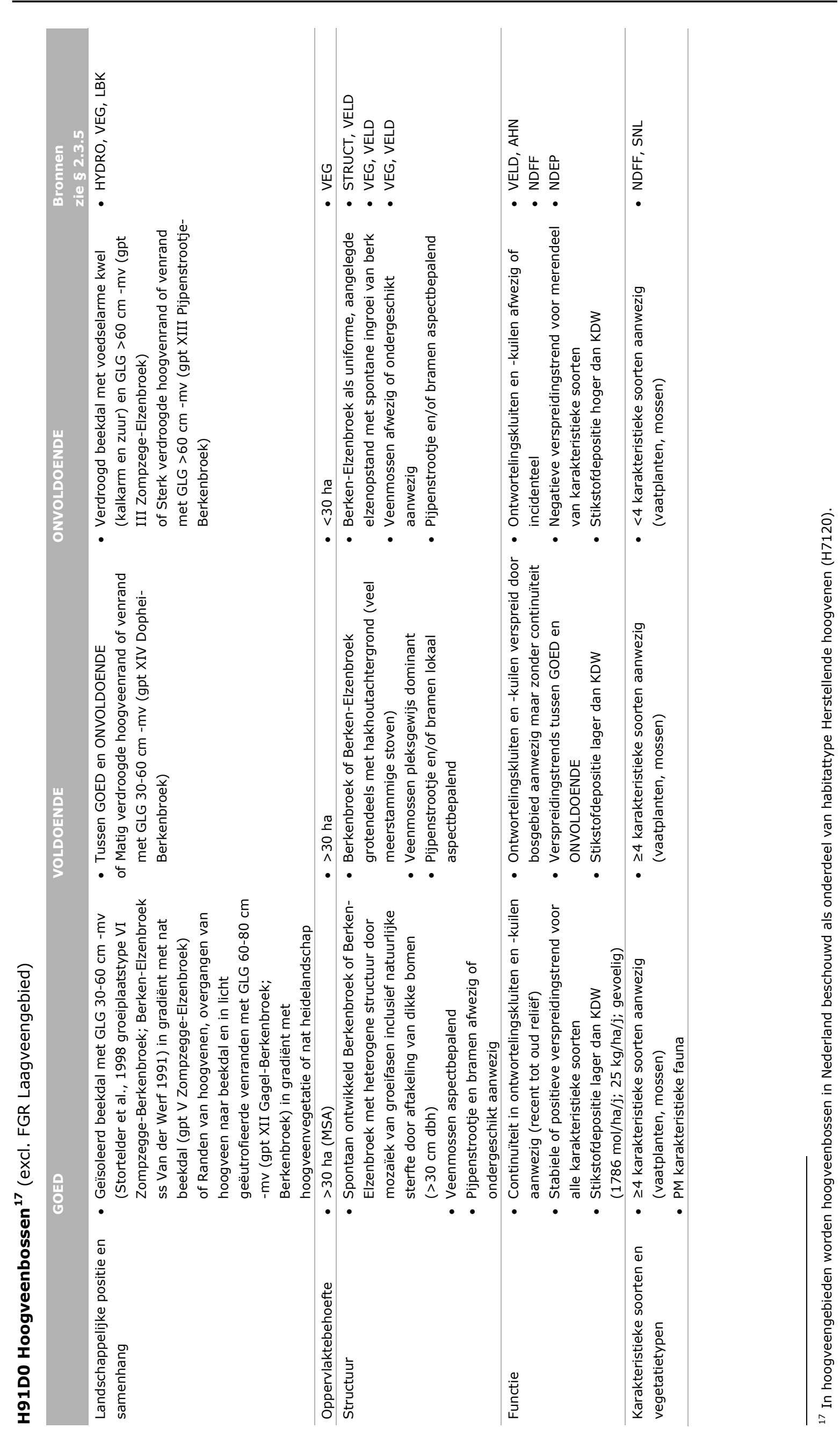

66 | Wageningen Environmental Research Rapport 3036 


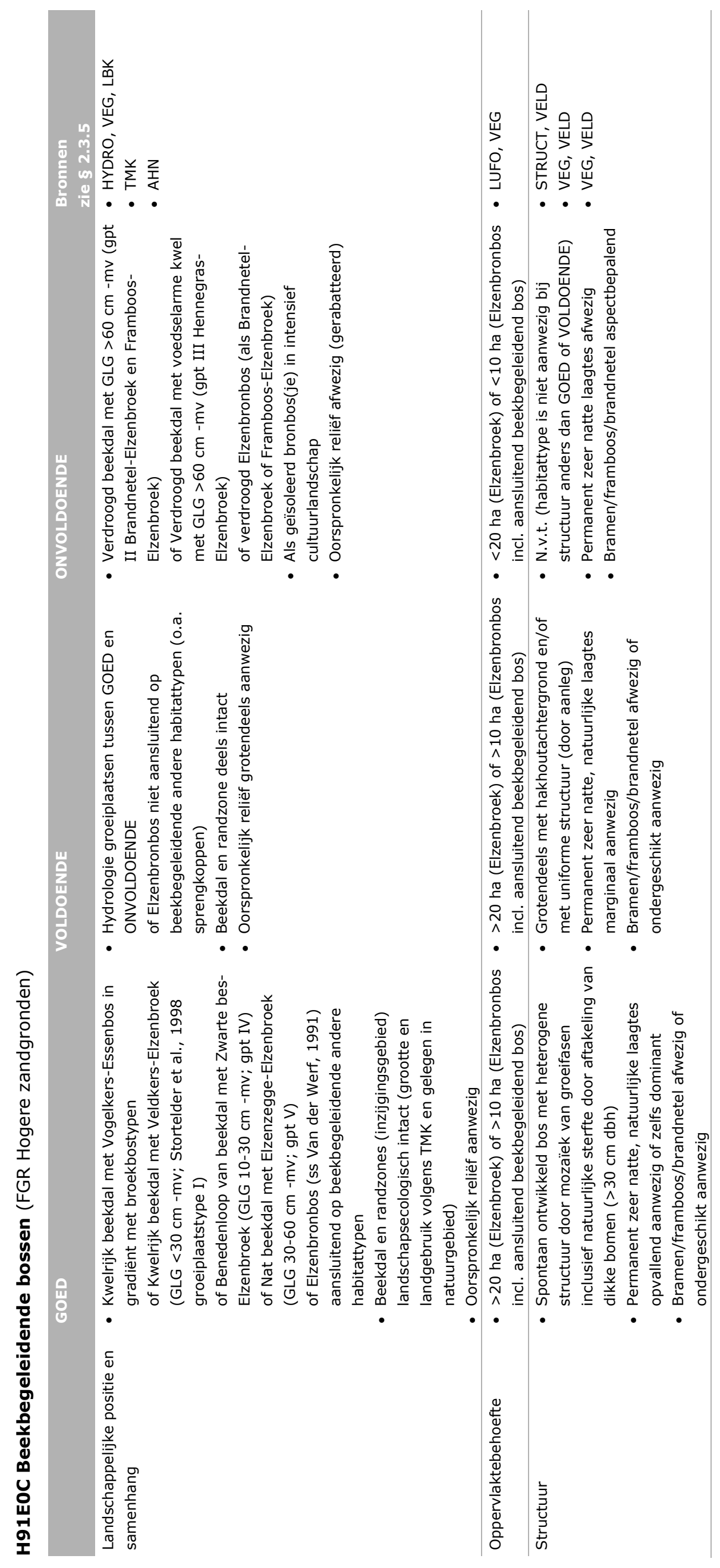




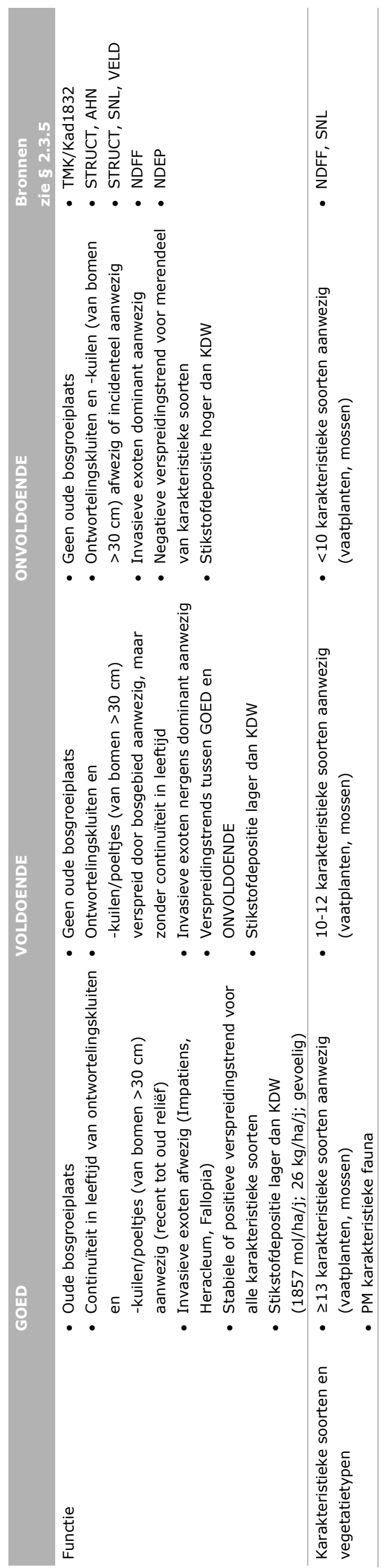

68 | Wageningen Environmental Research Rapport 3036 


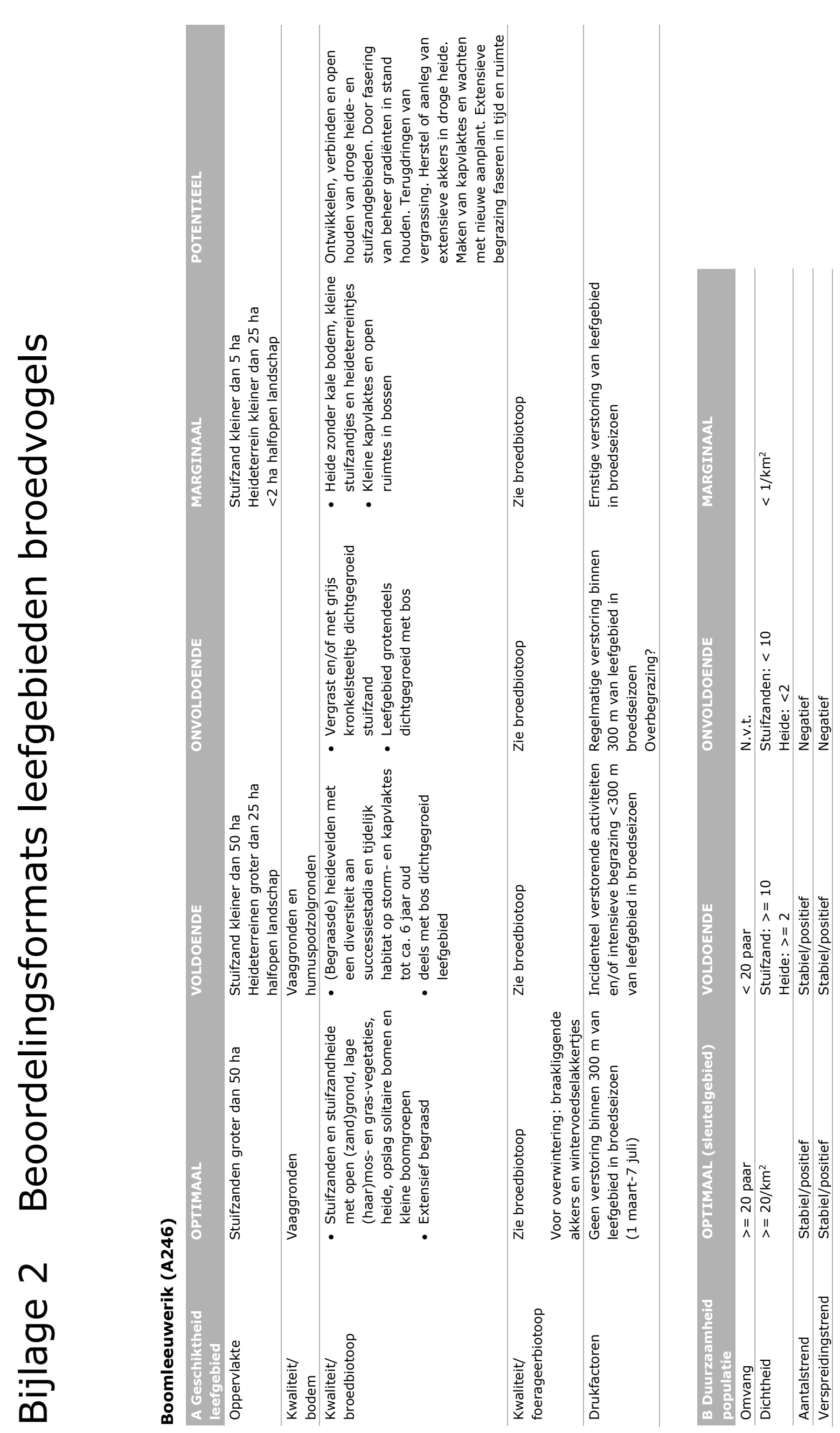




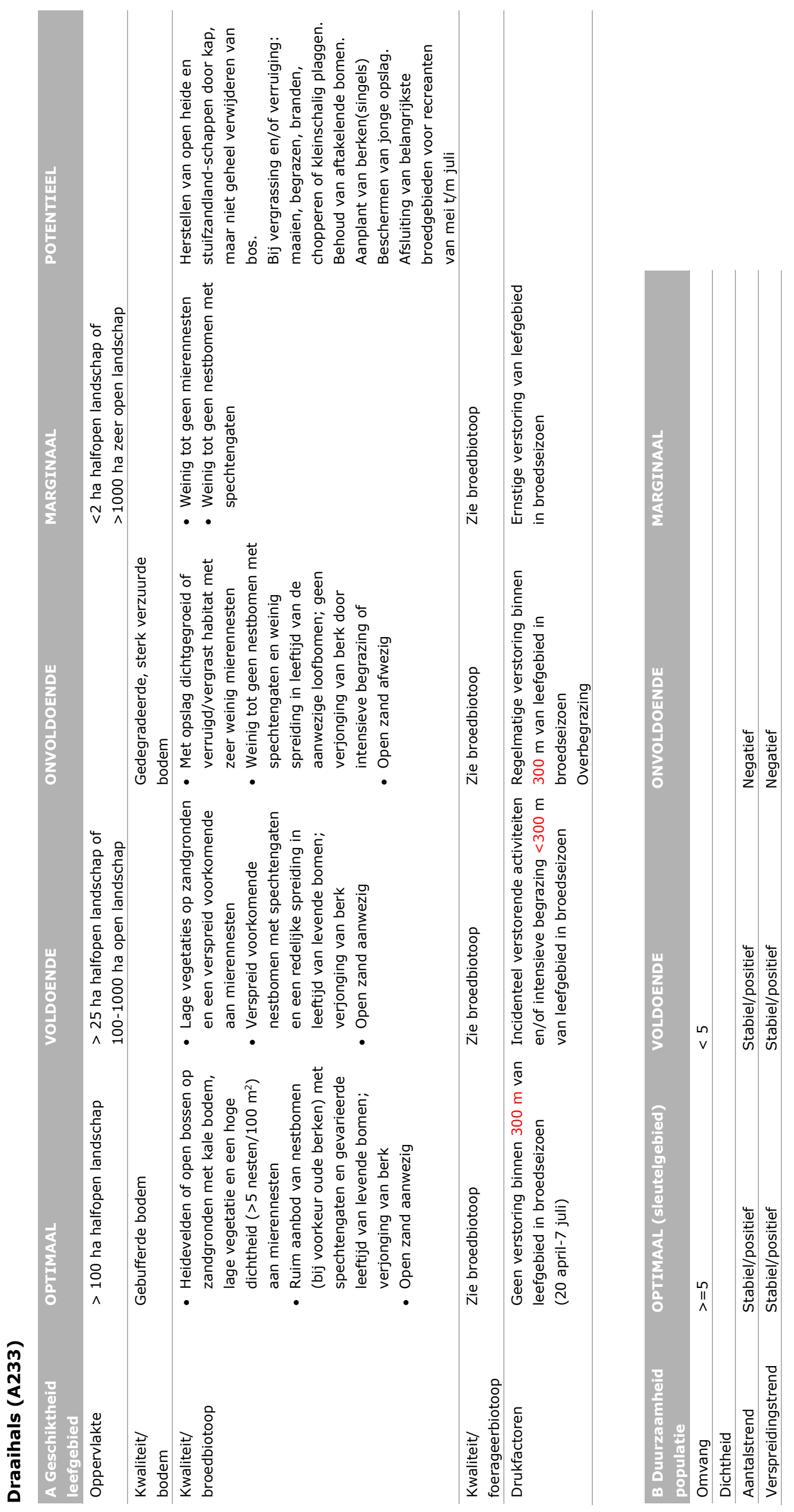




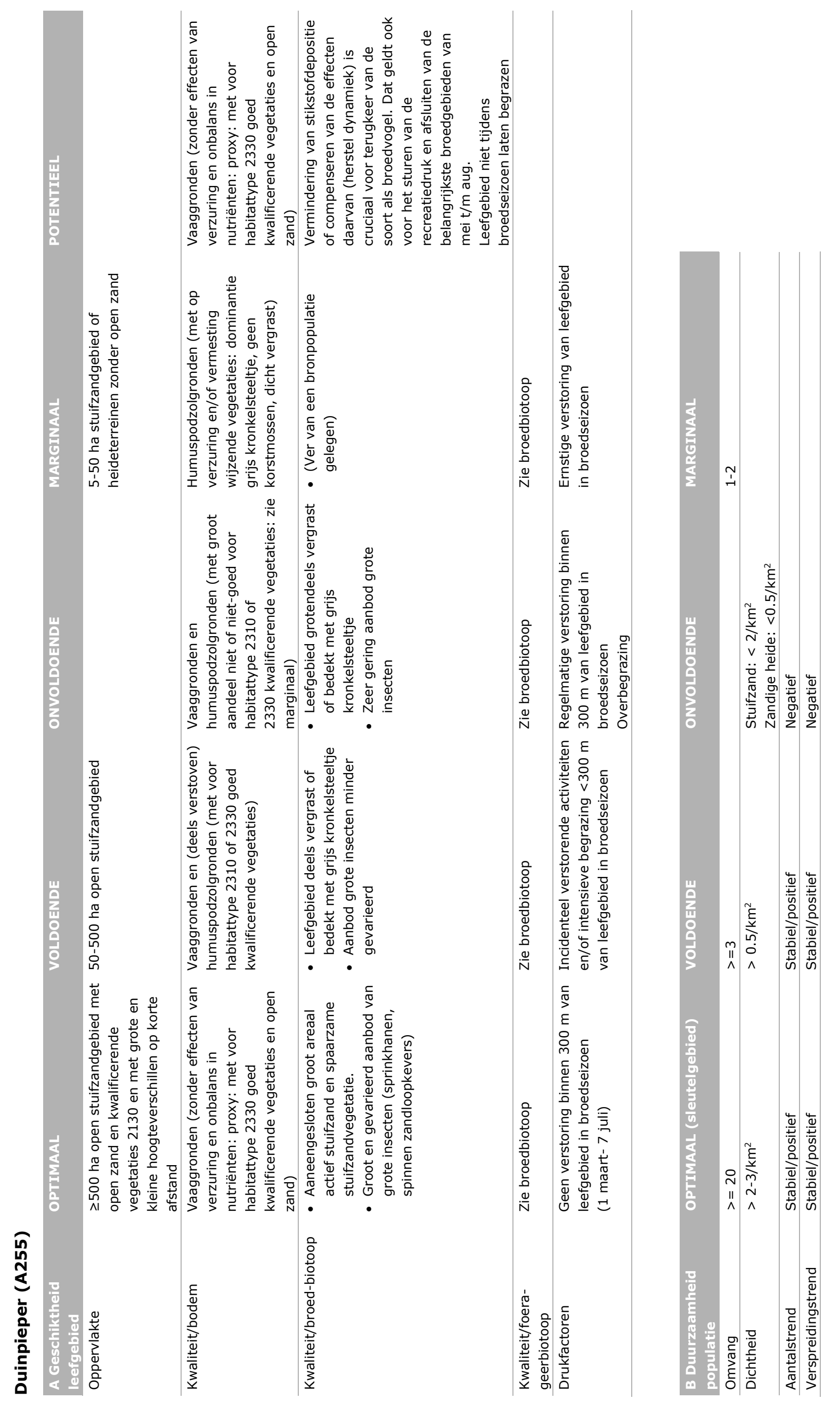




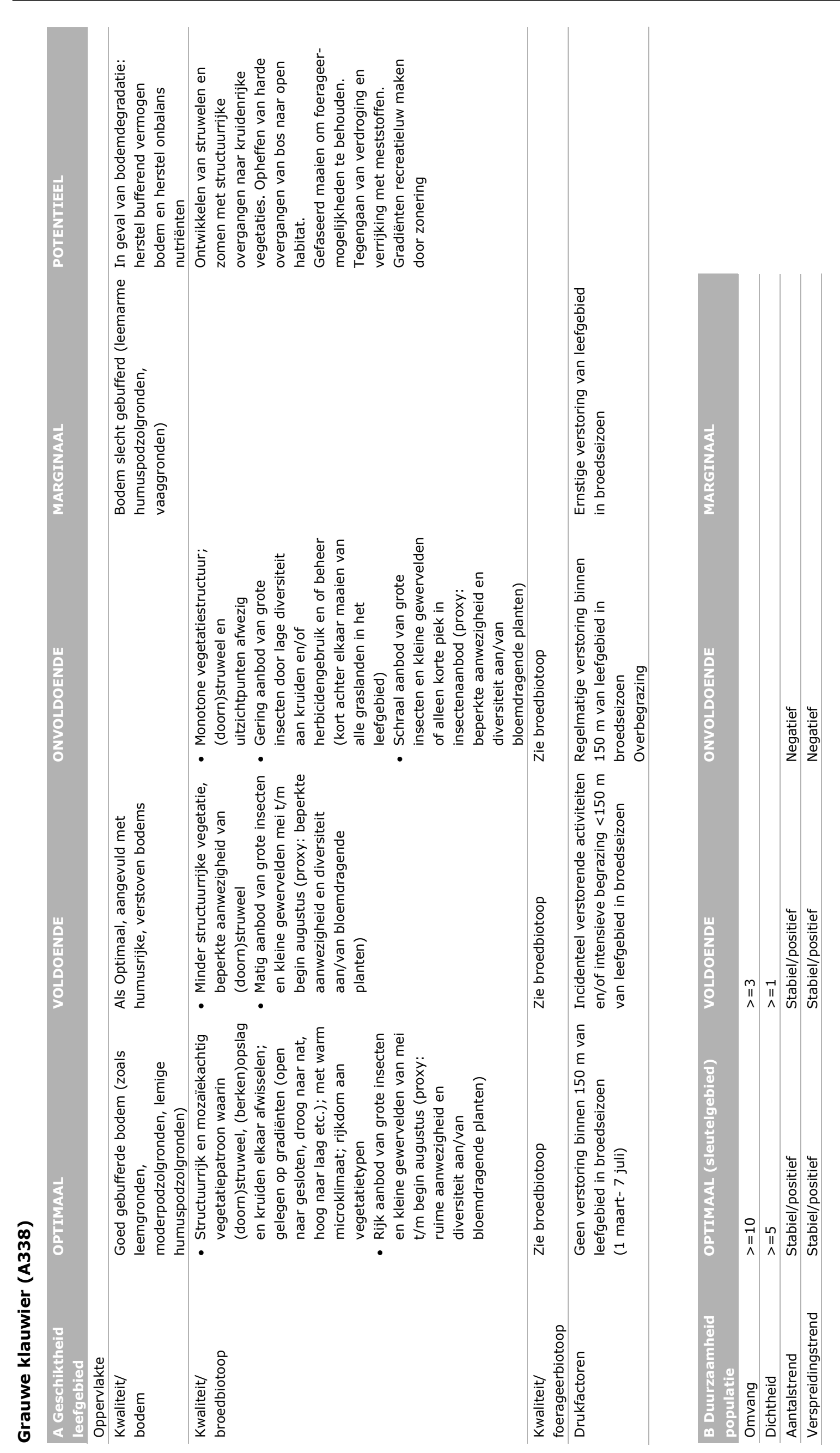

72 | Wageningen Environmental Research Rapport 3036 


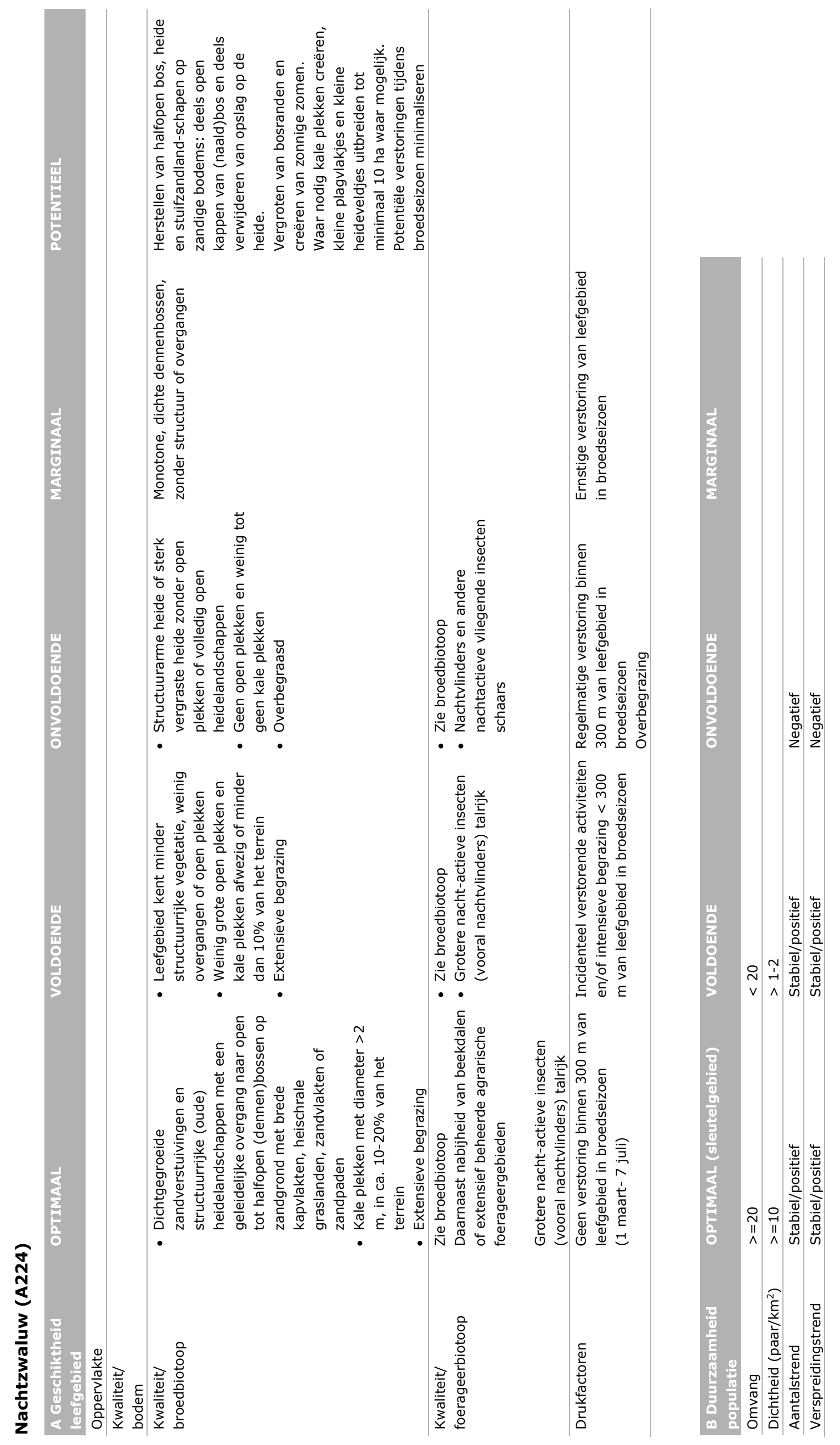




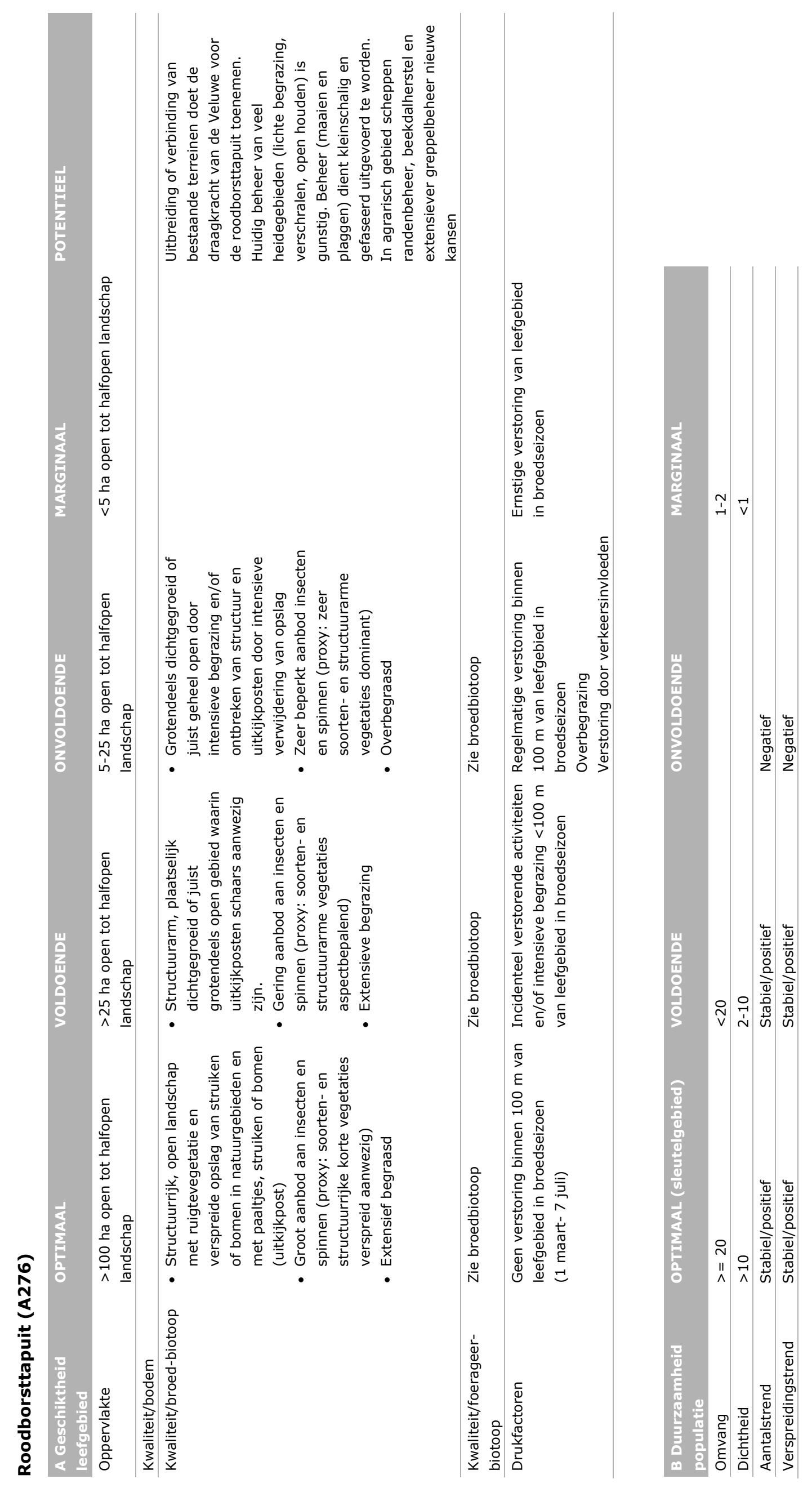




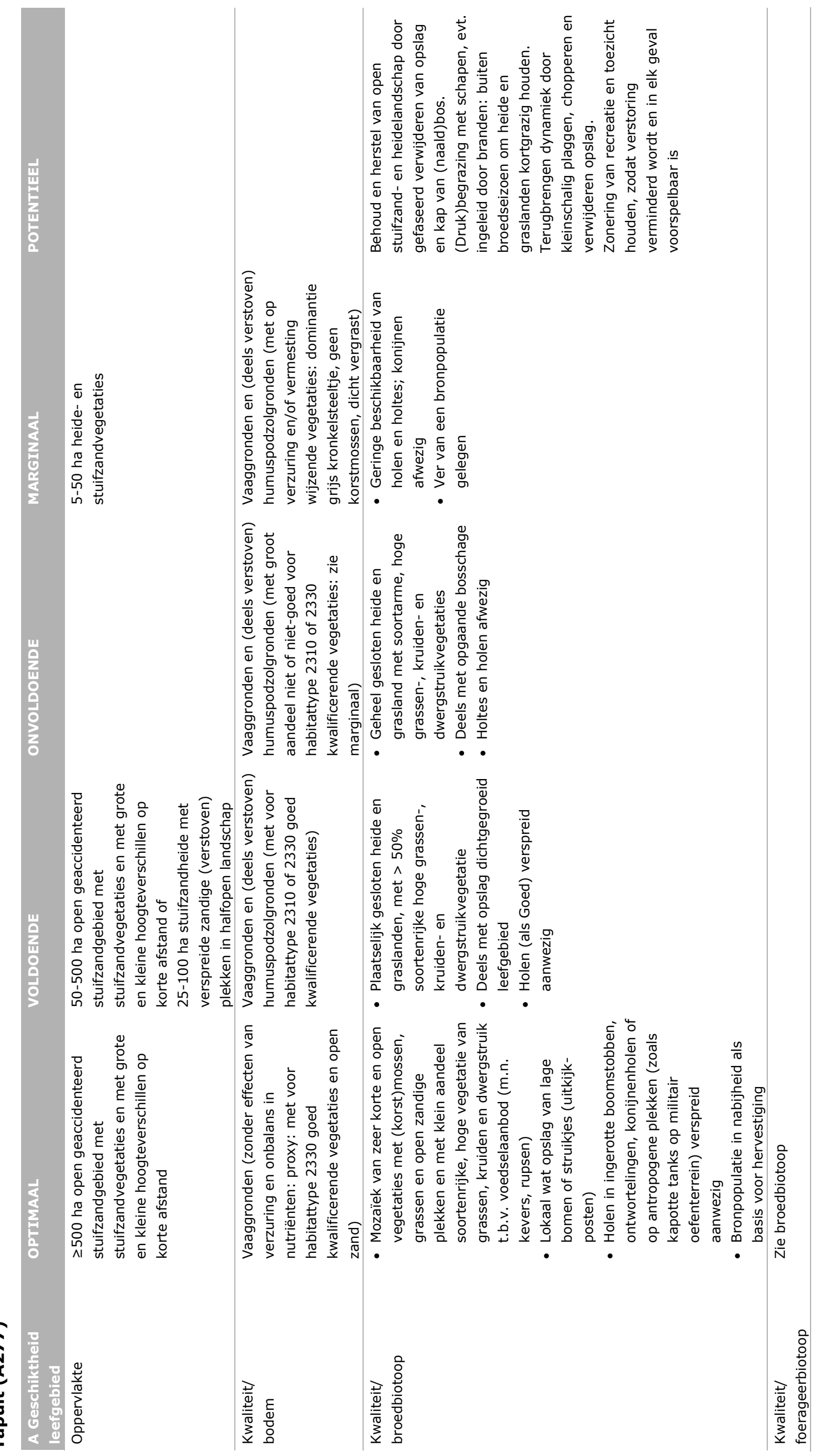




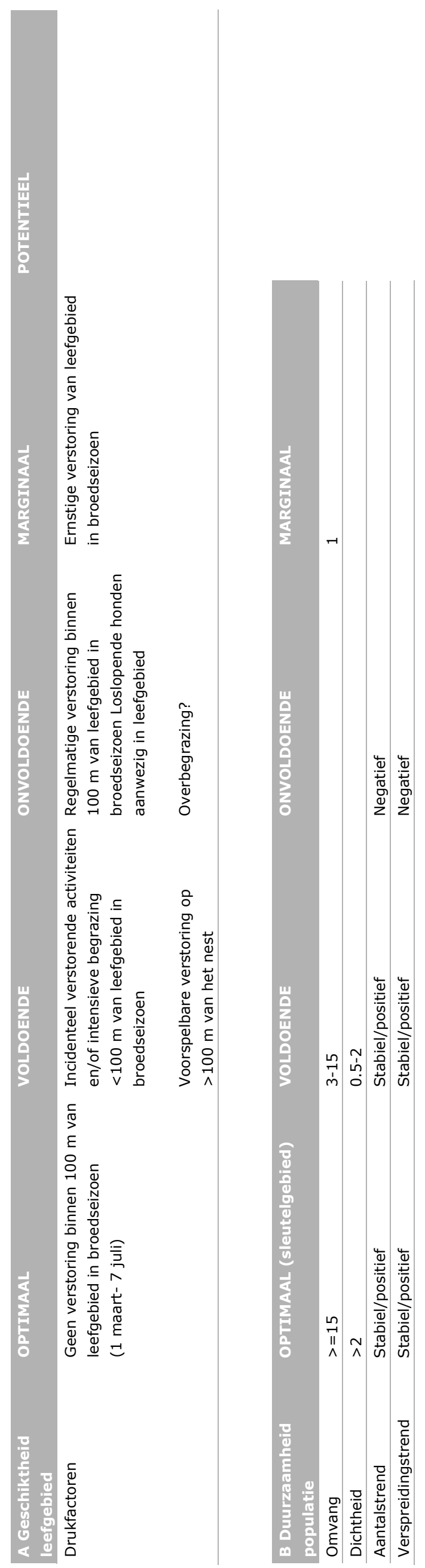

76 | Wageningen Environmental Research Rapport 3036 


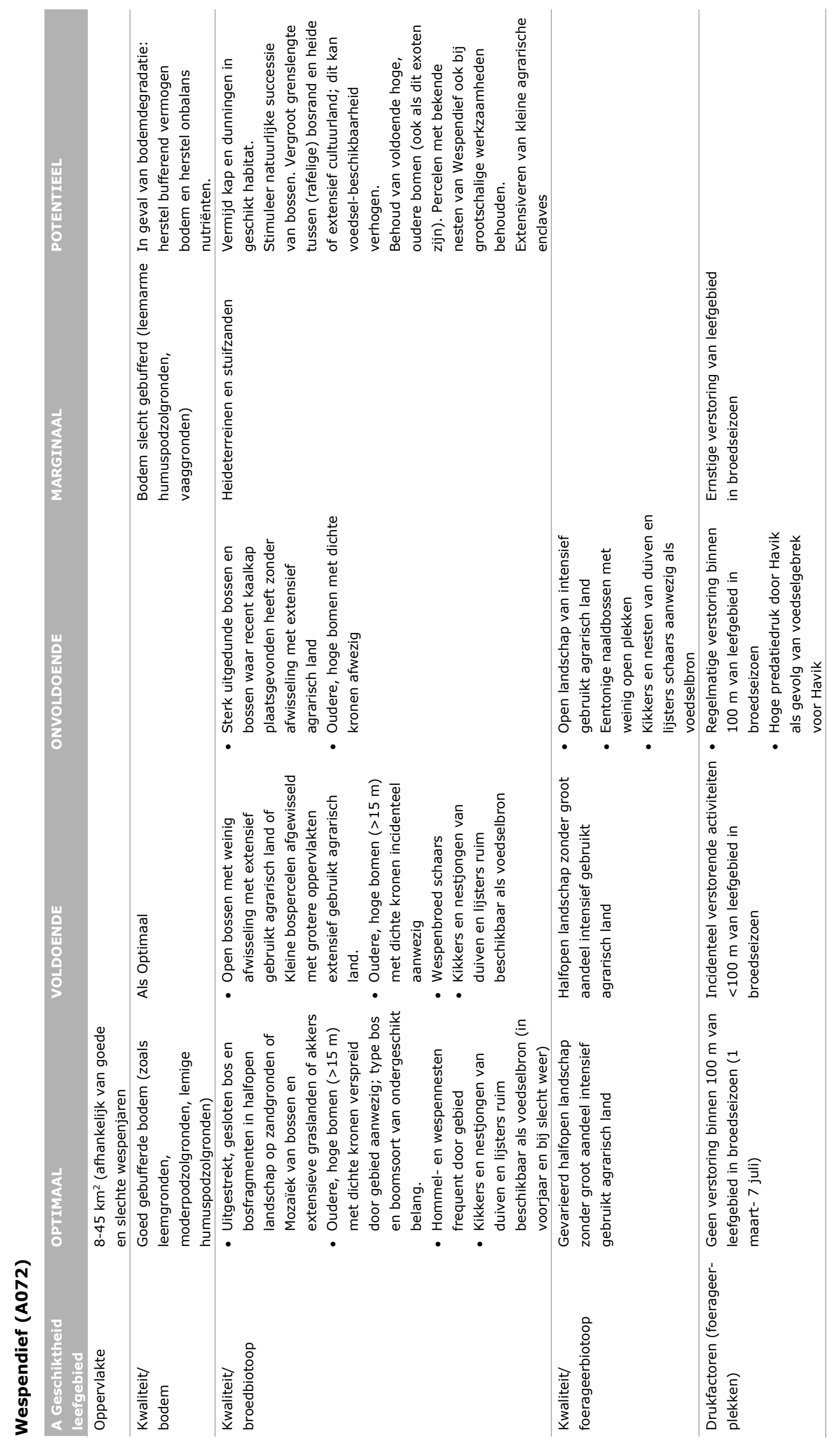




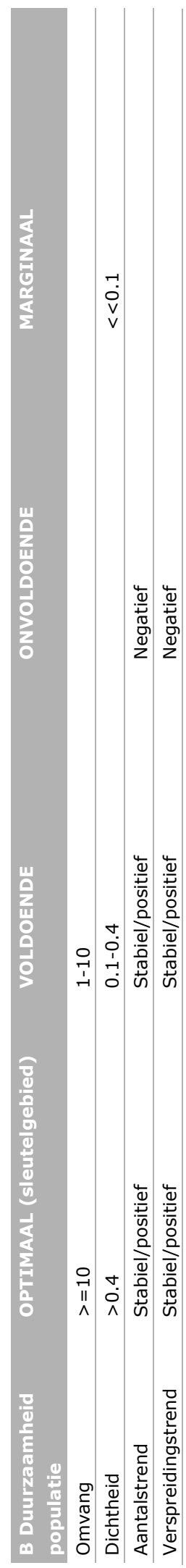

78 | Wageningen Environmental Research Rapport 3036 


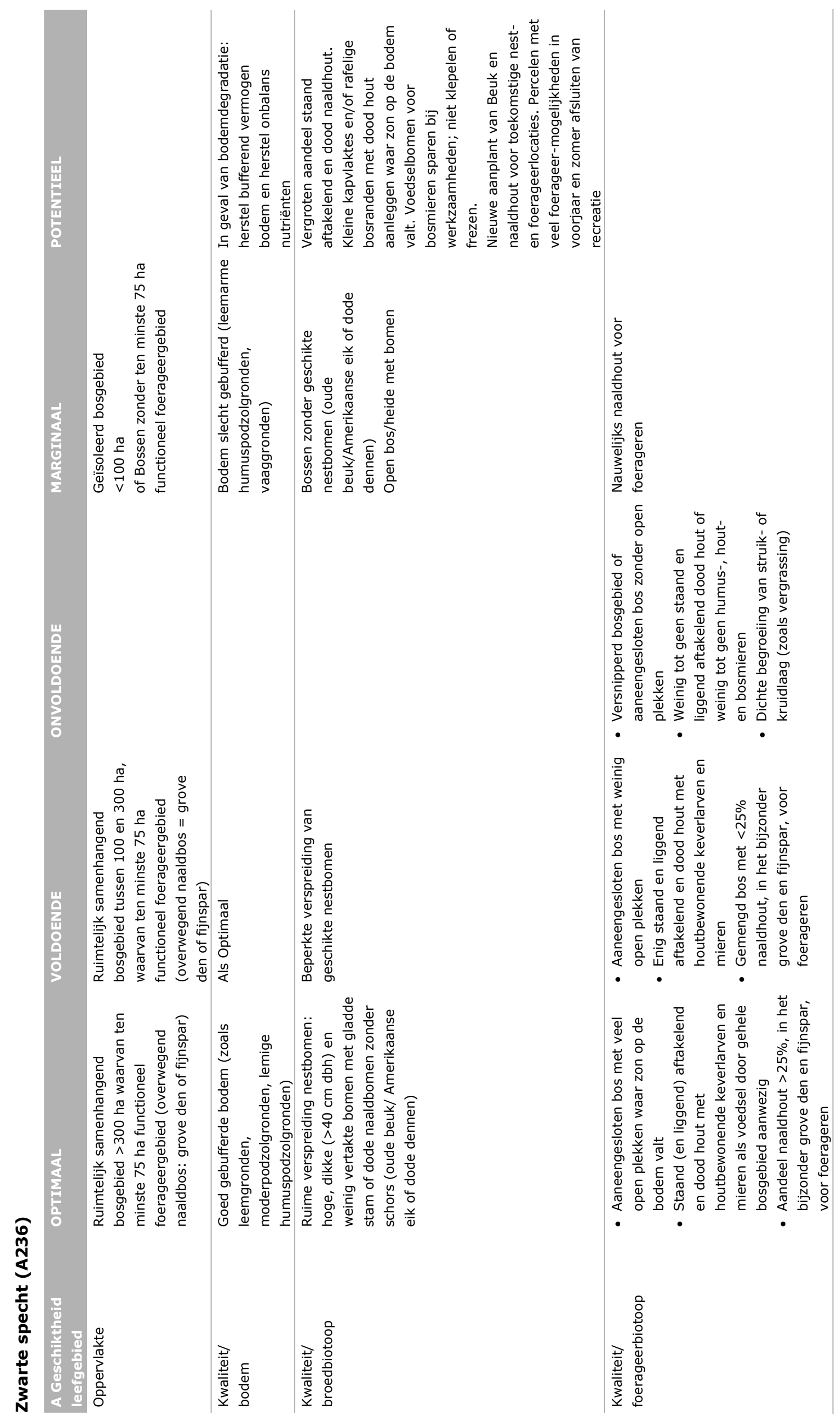




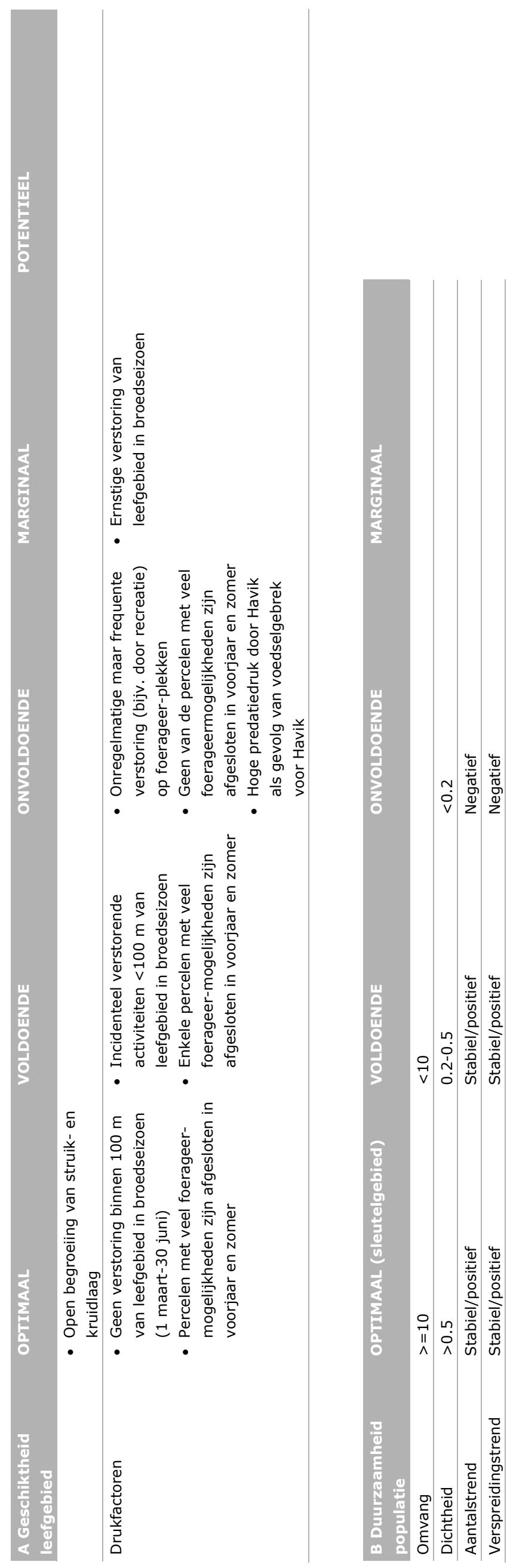

80 | Wageningen Environmental Research Rapport 3036 


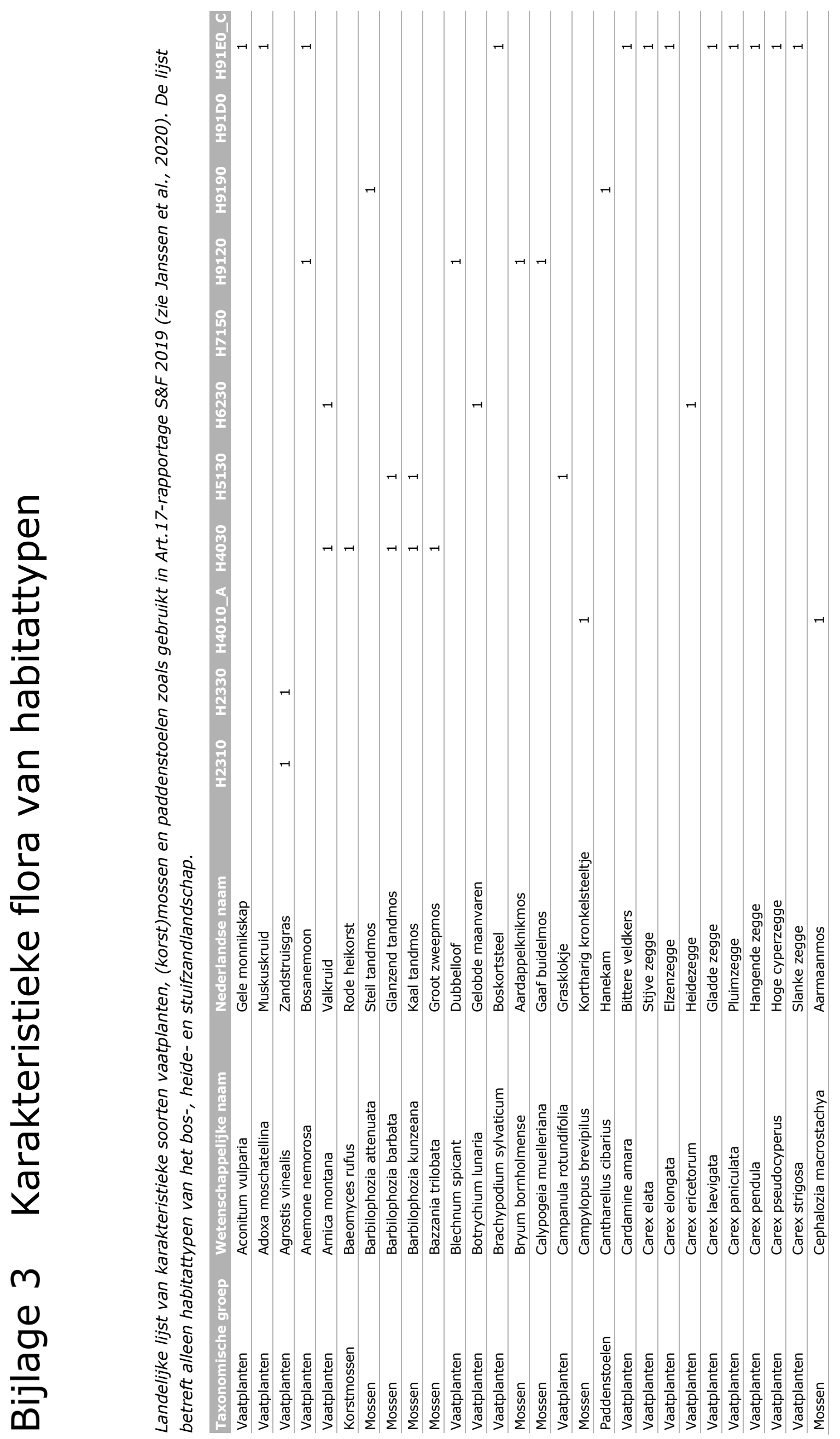

Wageningen Environmental Research Rapport 3036 | 81 


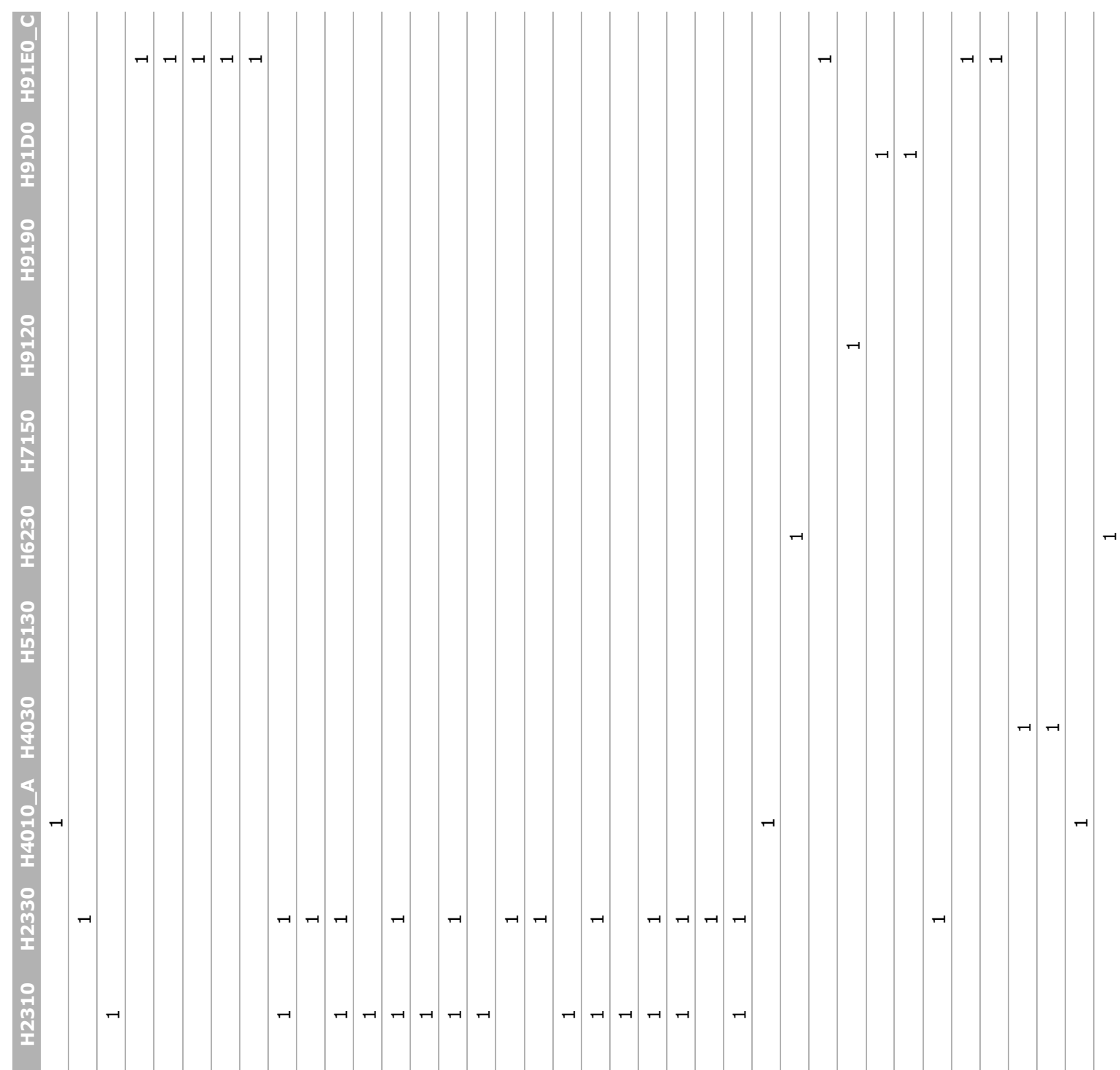

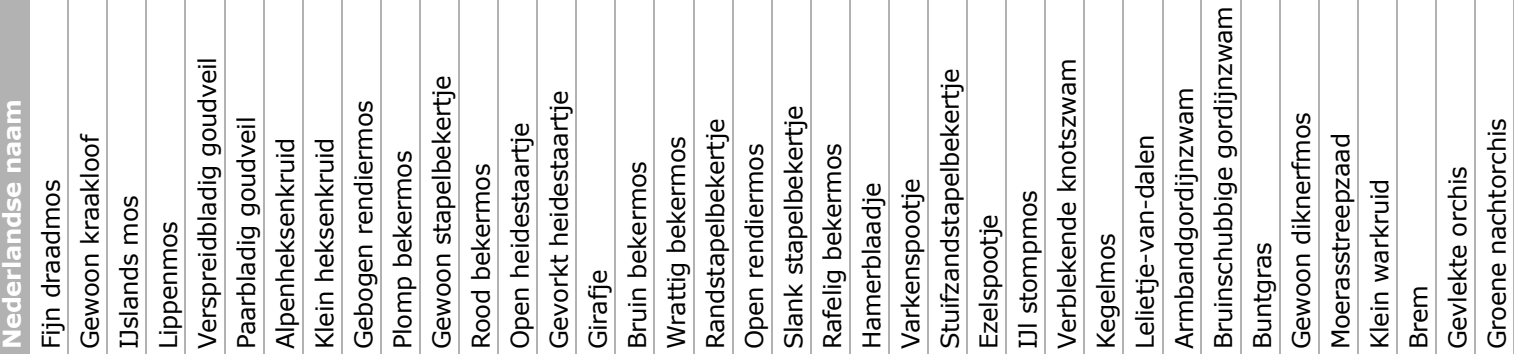

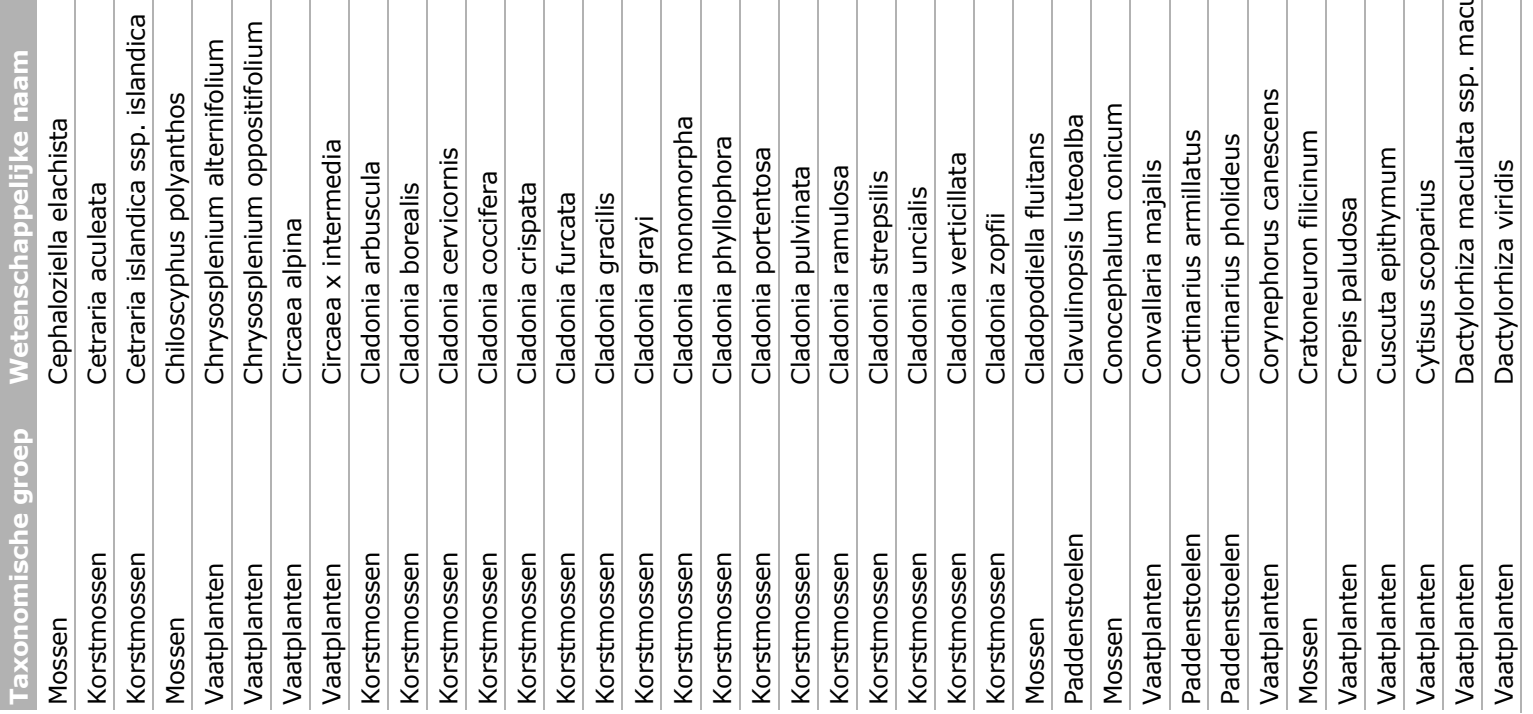




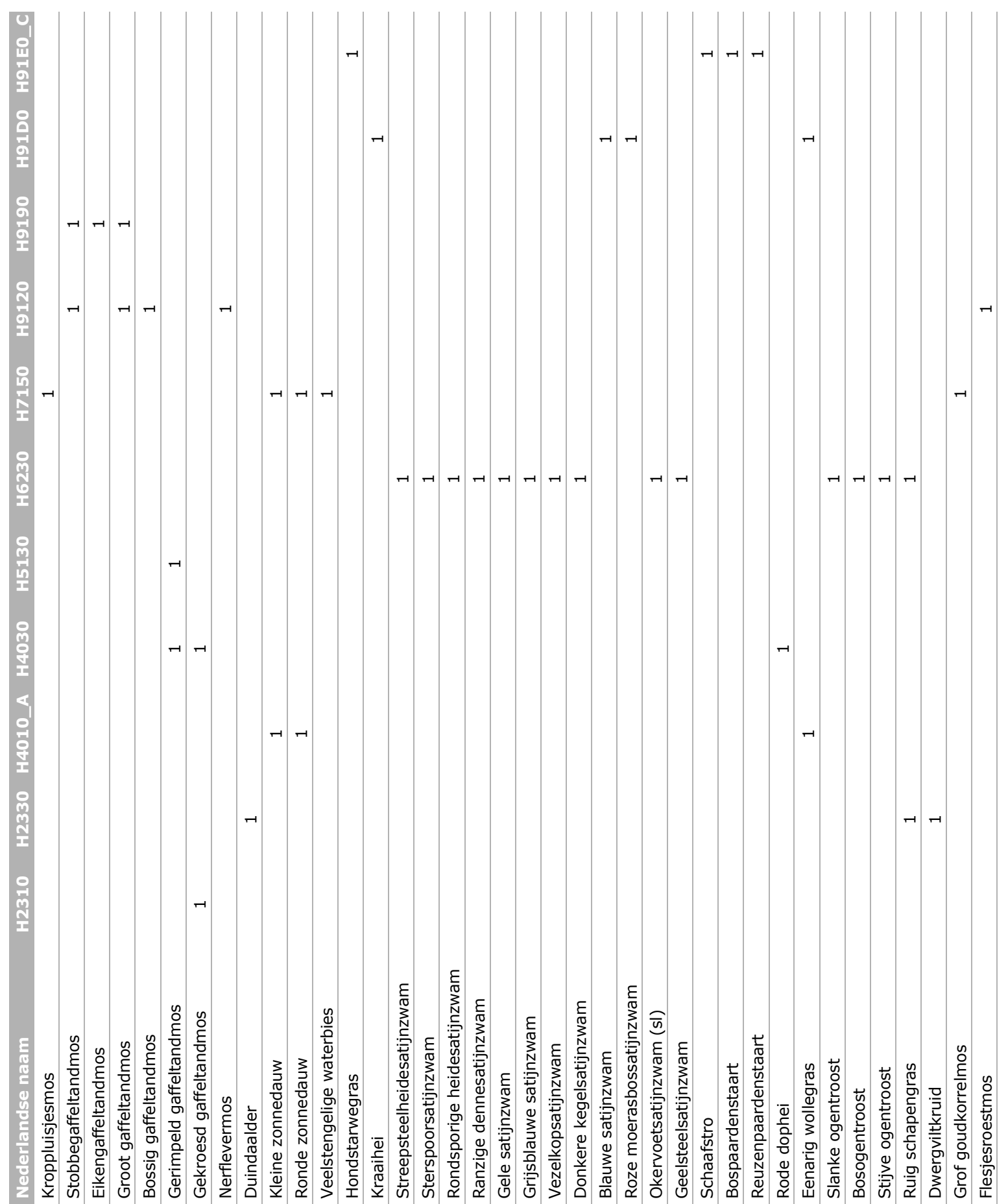

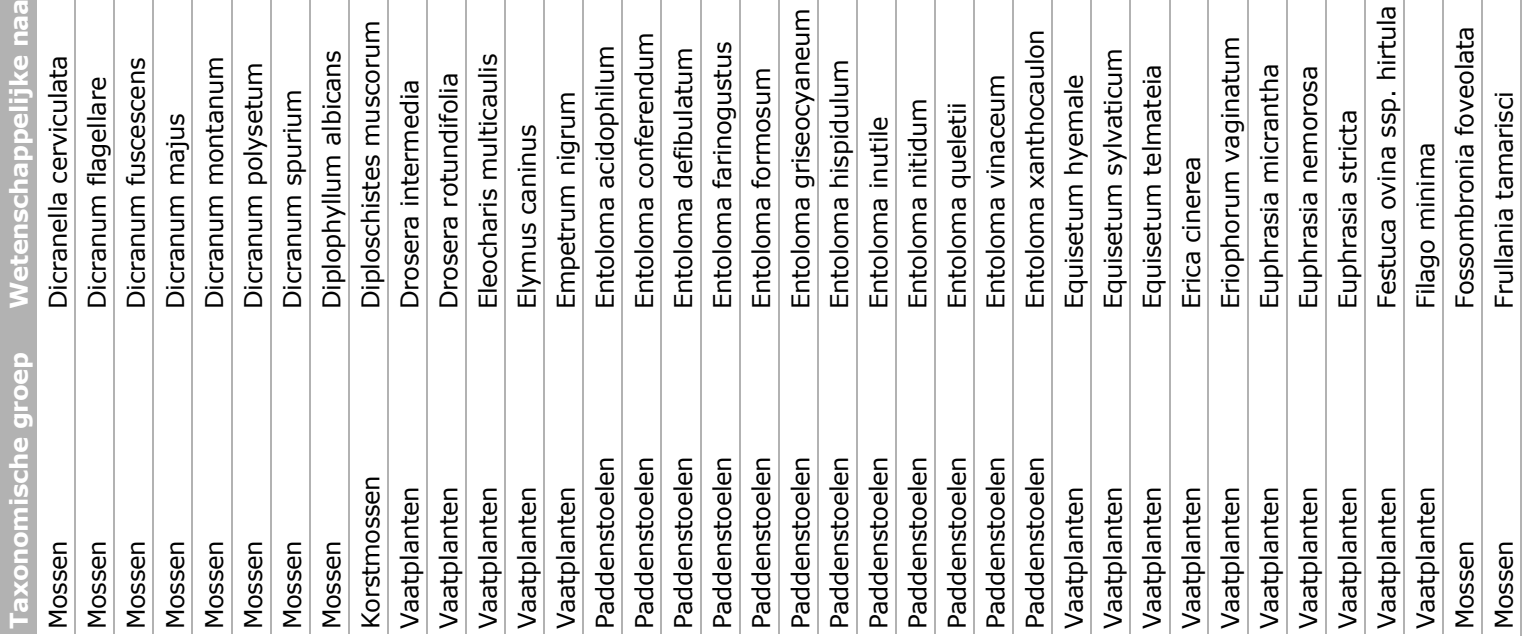




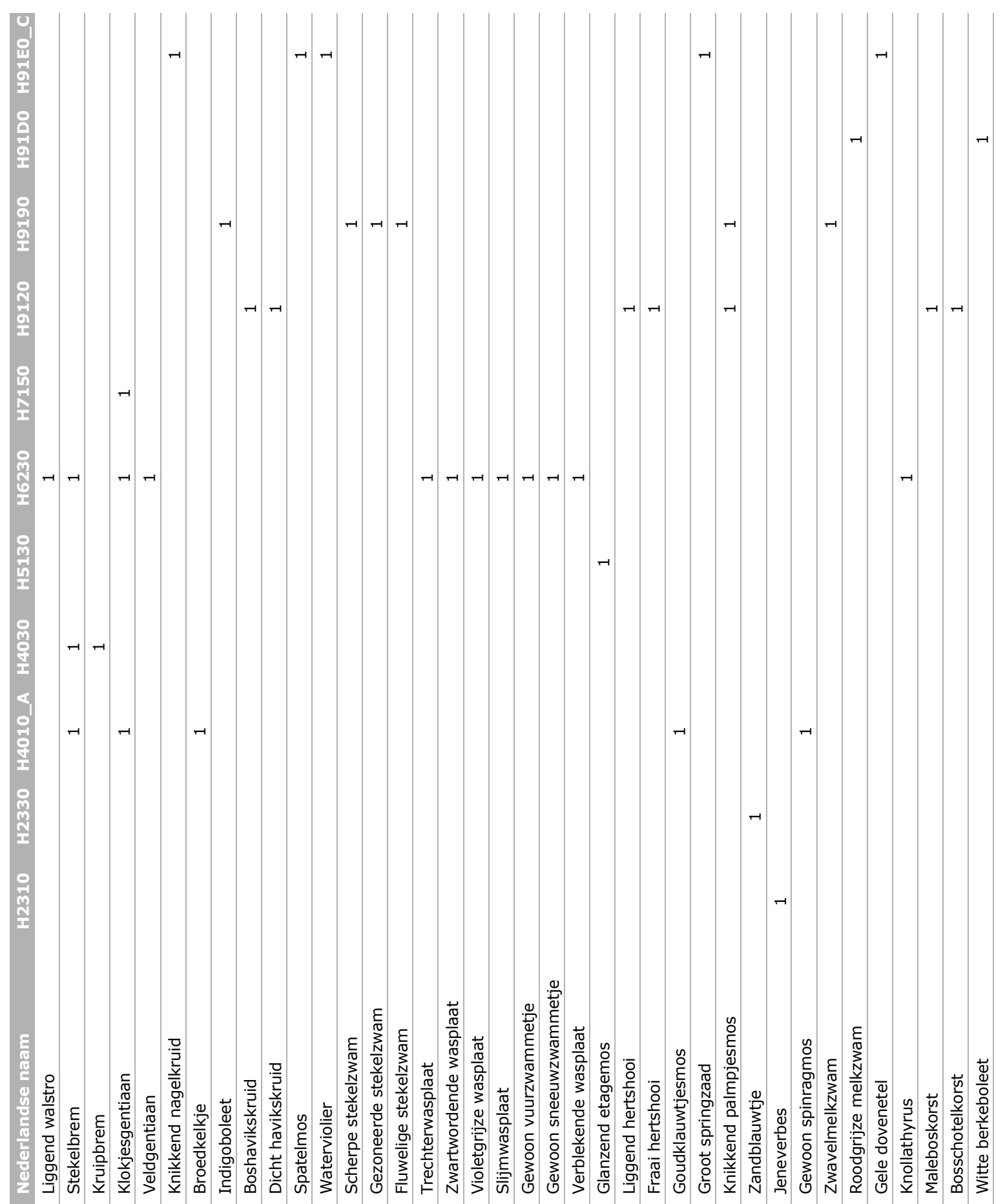

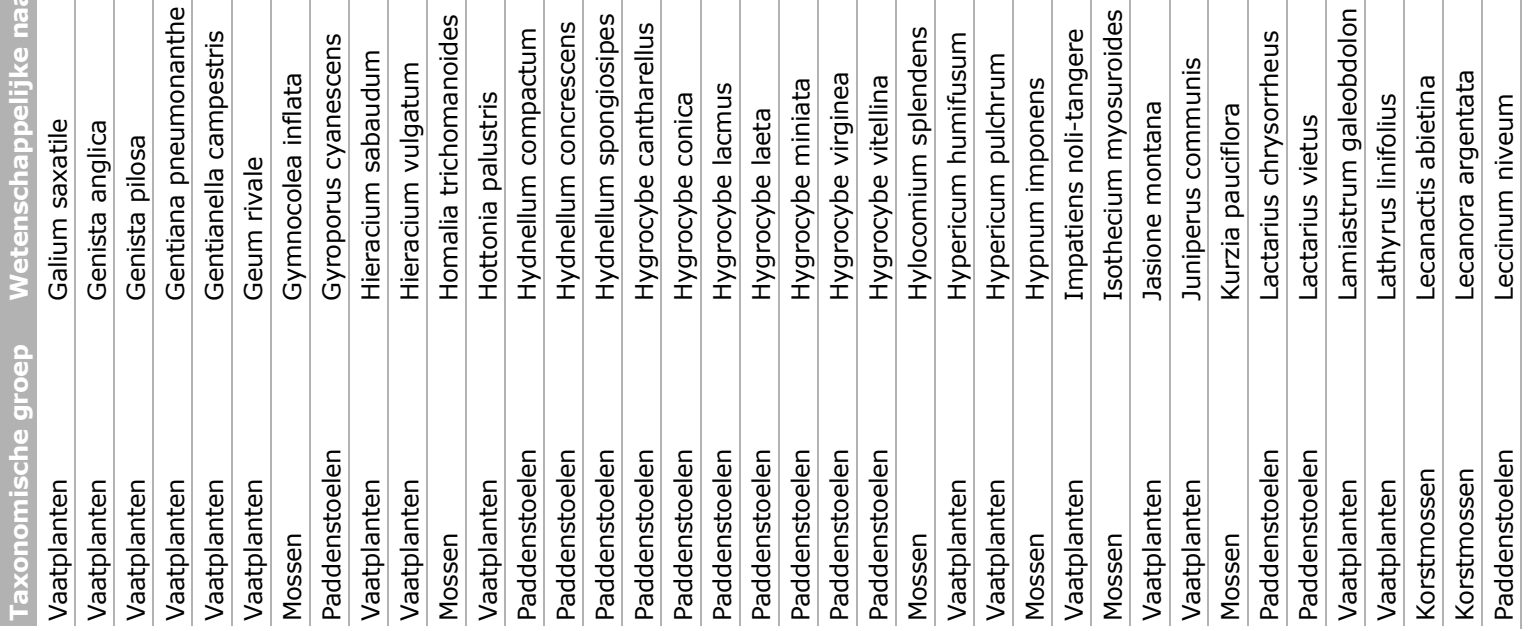

84 | Wageningen Environmental Research Rapport 3036 


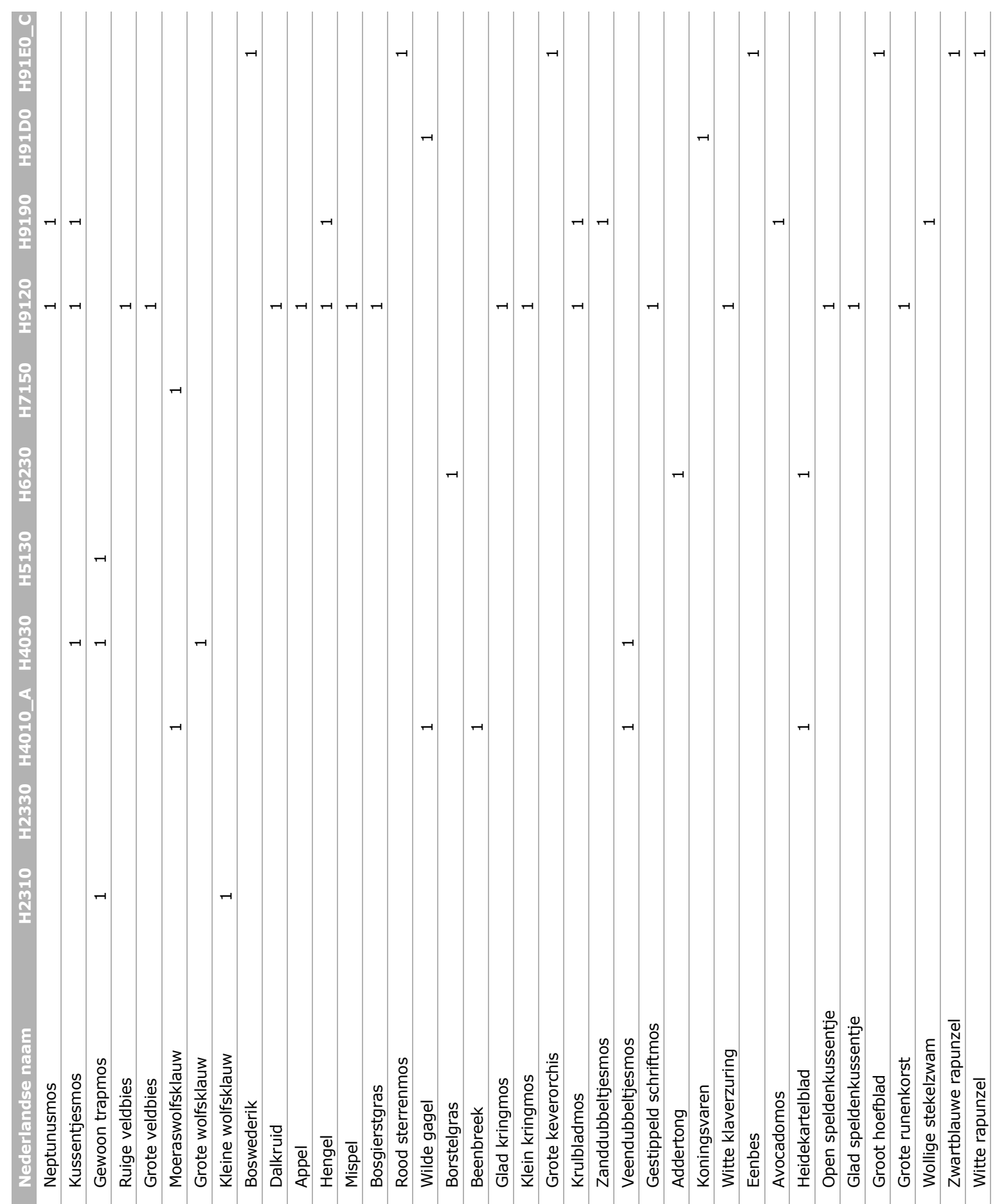

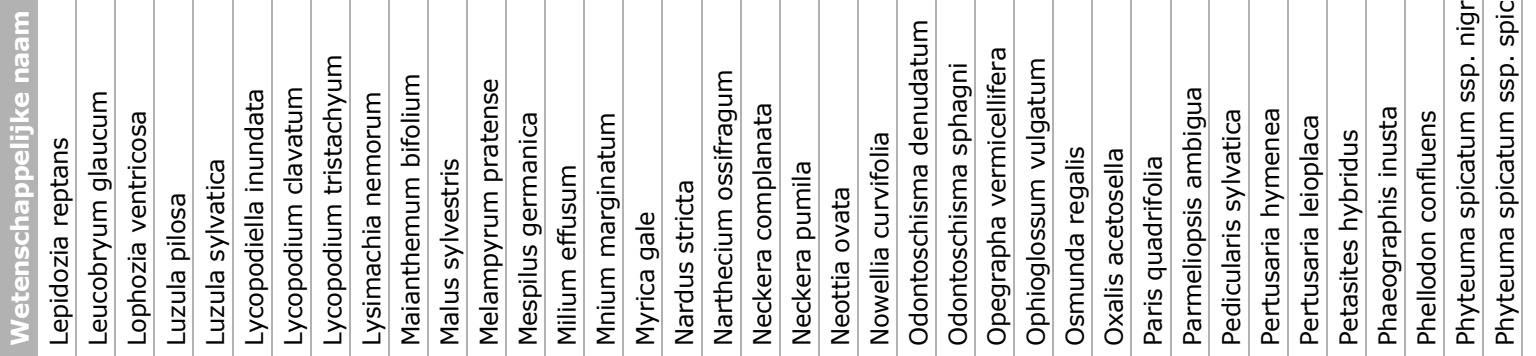

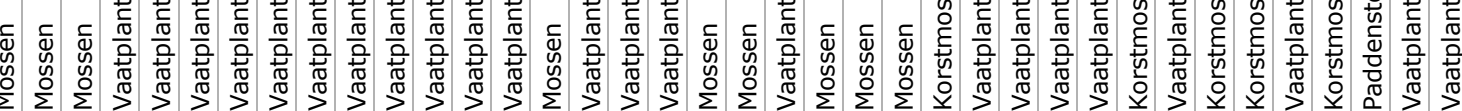




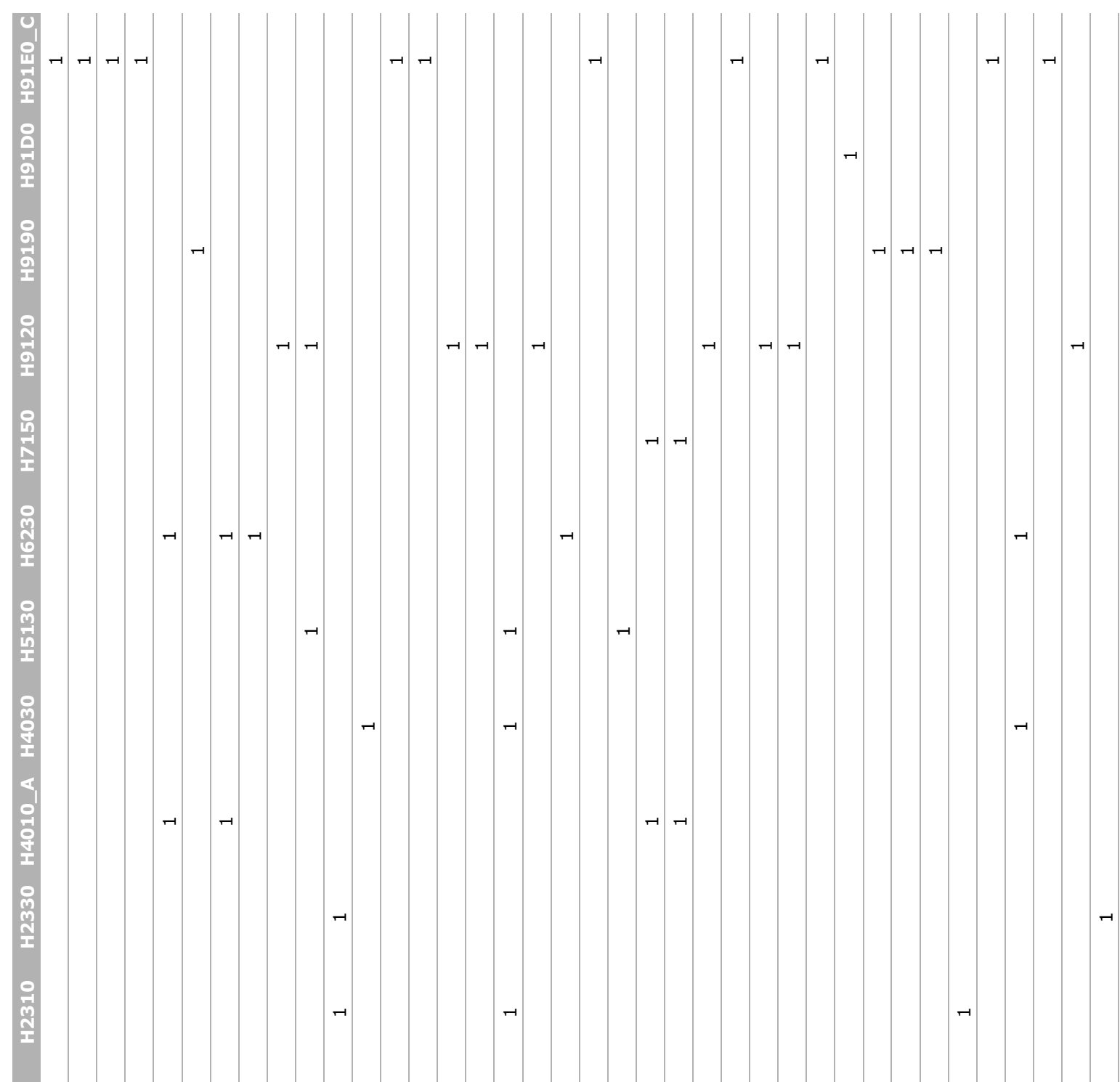

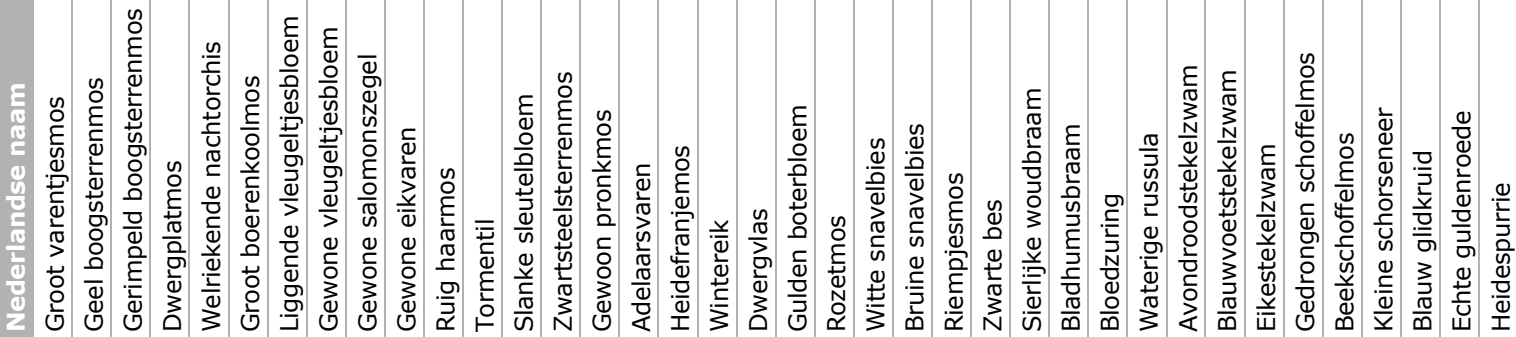

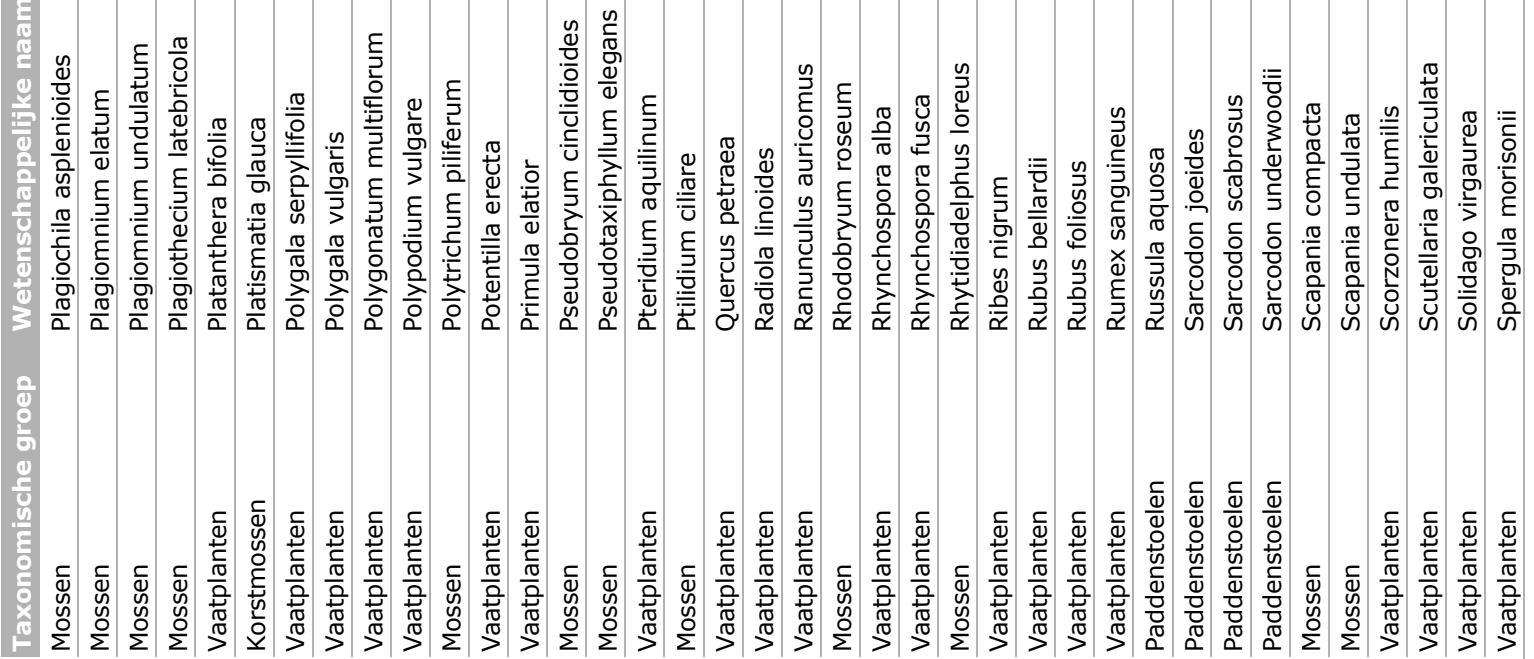




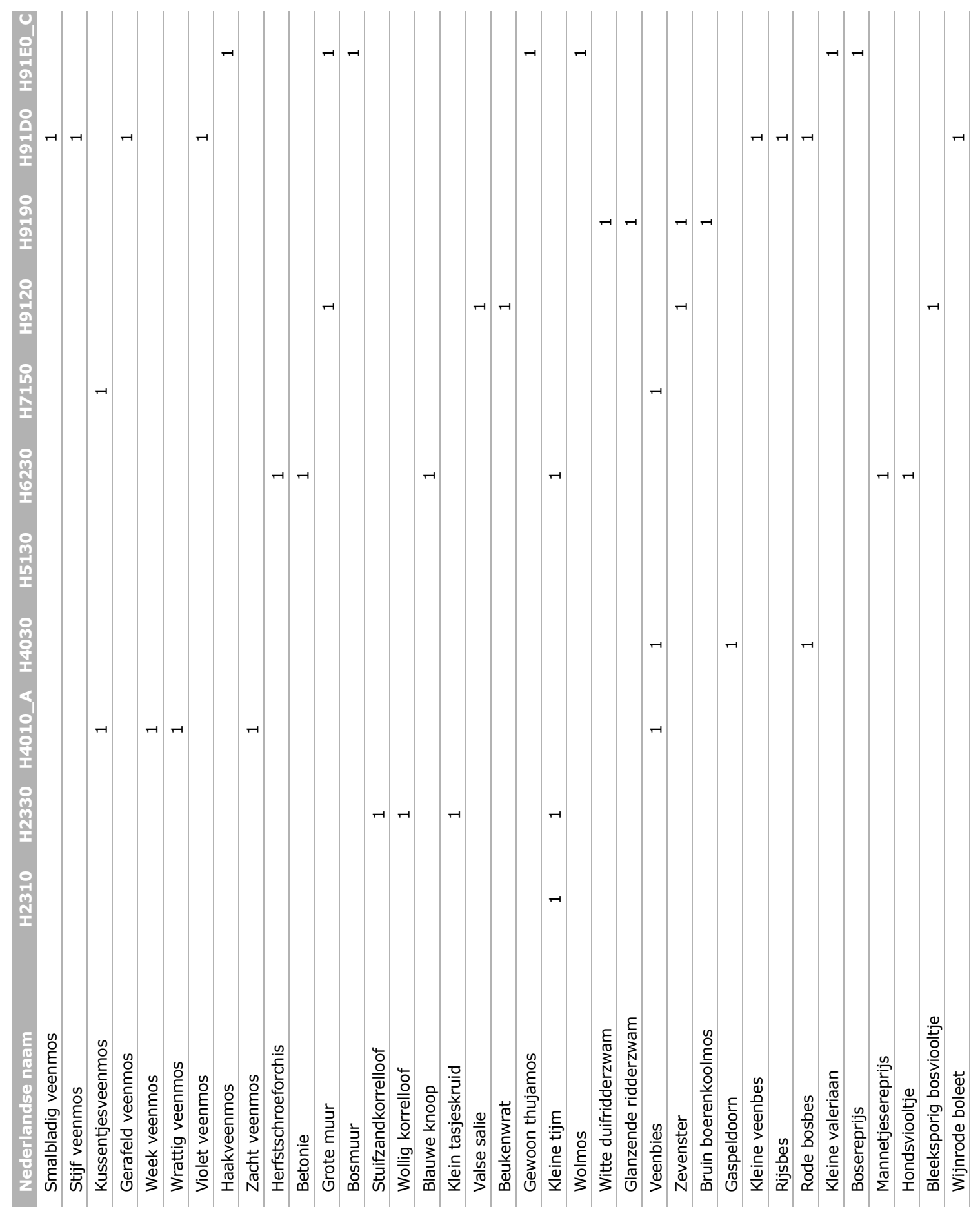

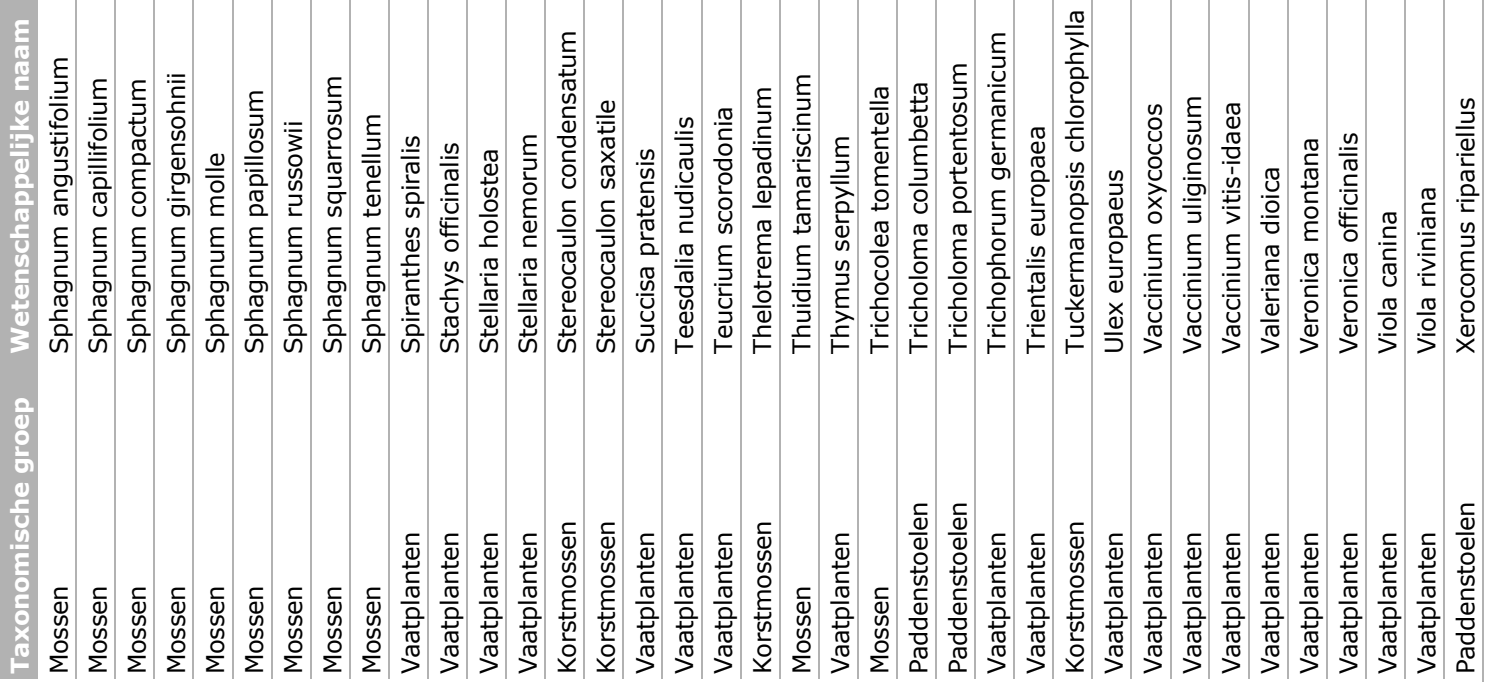


T

$$
\frac{1}{8}
$$

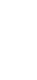

(1)
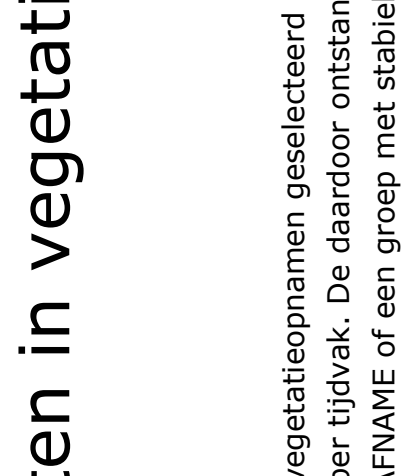

눙

$\stackrel{\text { S }}{\frac{1}{D}}$

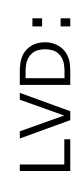

$\frac{\substack{0 \\ \frac{10}{\pi}}}{\frac{1}{2}}$

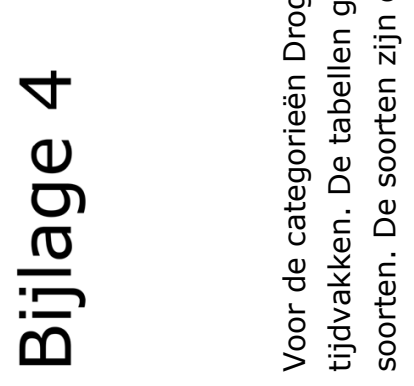

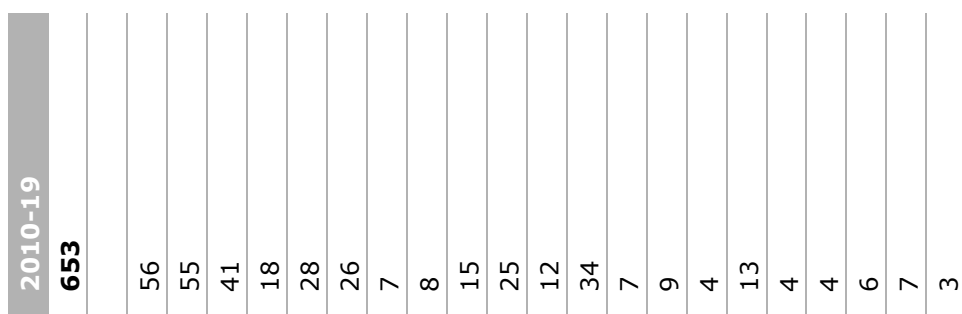

党

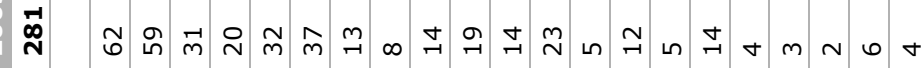

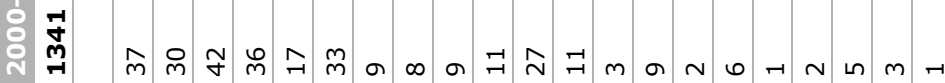

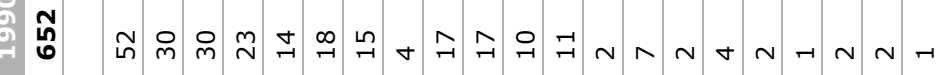

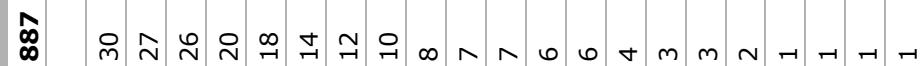

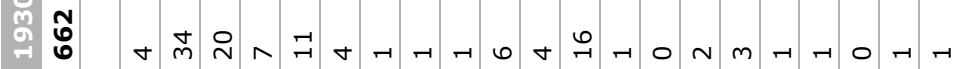


웜

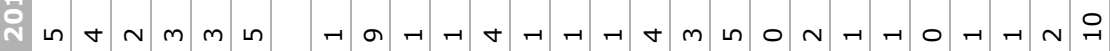

家

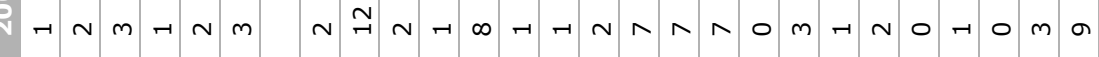

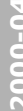

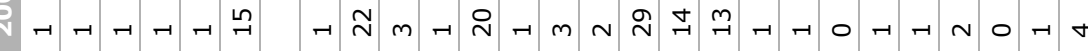

항

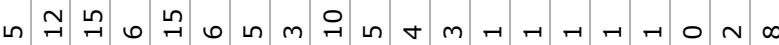

\begin{tabular}{ll}
$\infty$ \\
$\infty$ \\
$\infty$ \\
\hdashline
\end{tabular}

$e^{-1} 0000^{-1}$

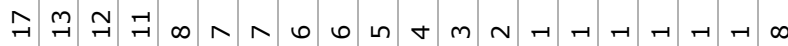

iे

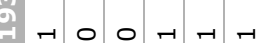

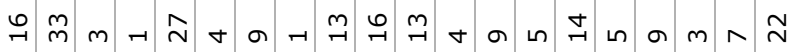

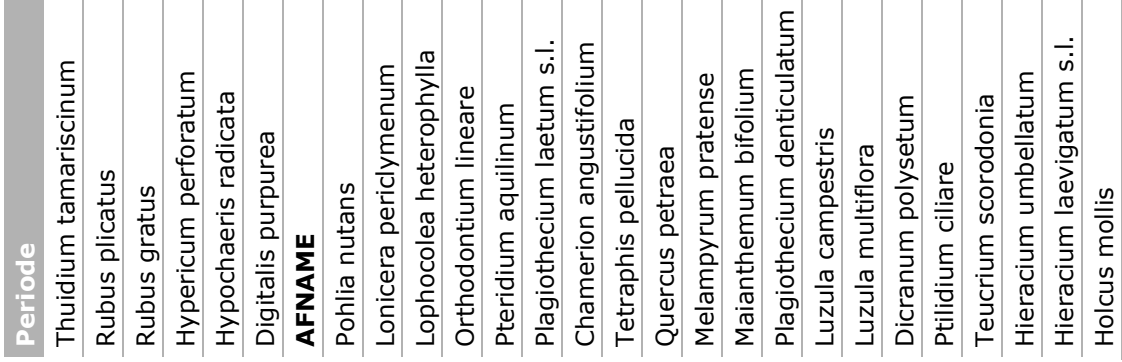




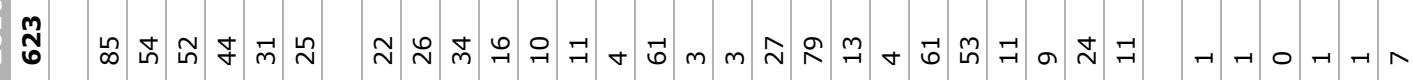

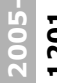

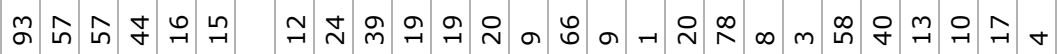

$4+10-100$

:

ถิ

\%े

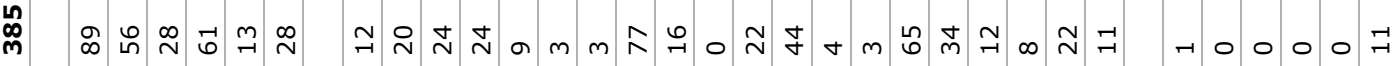

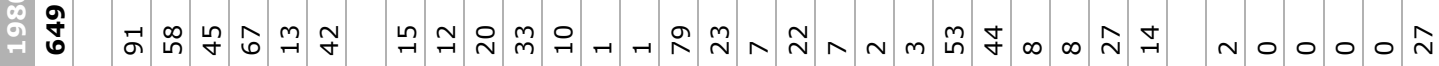

भ̆
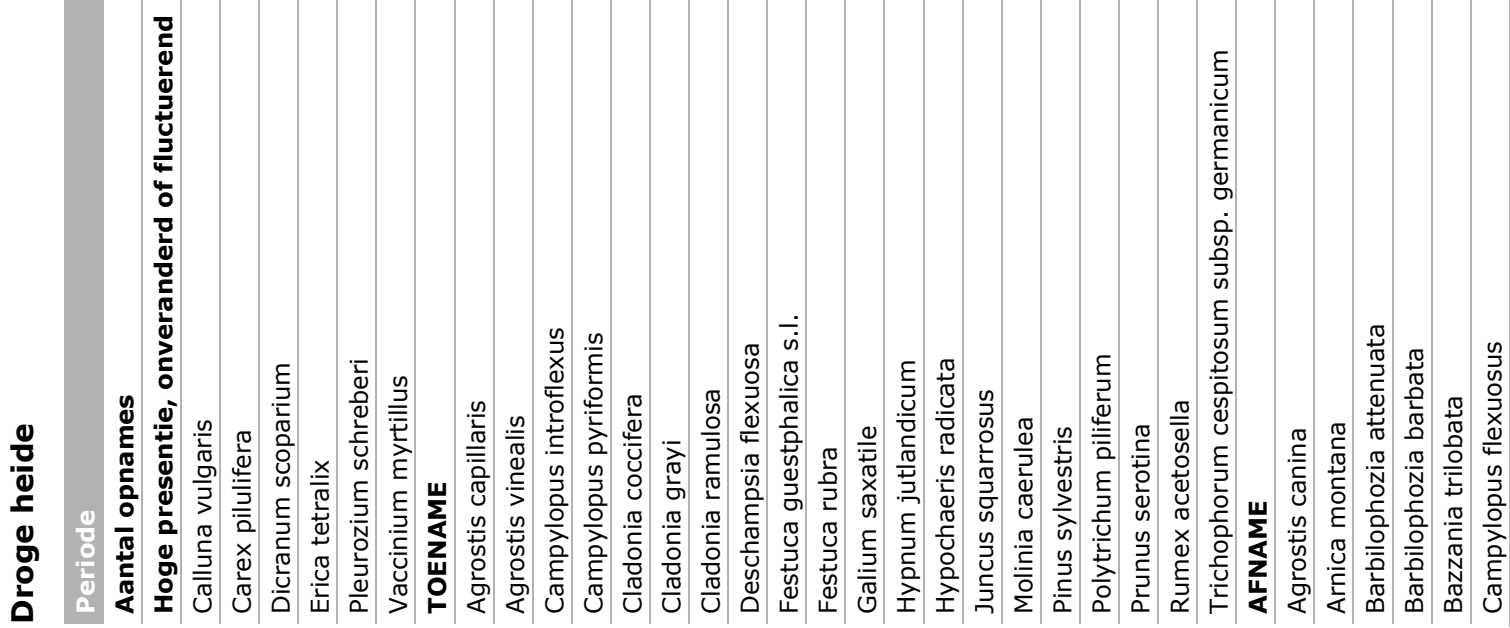
음

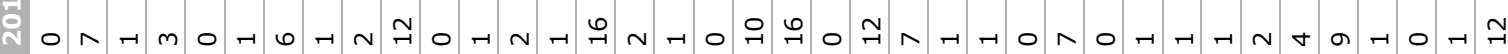

2
8
11

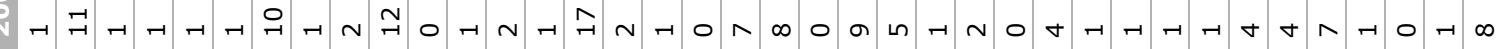

$\stackrel{8}{8}$

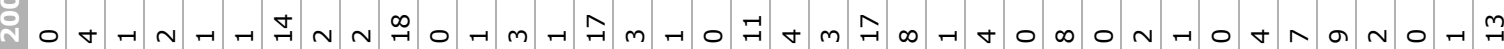

के

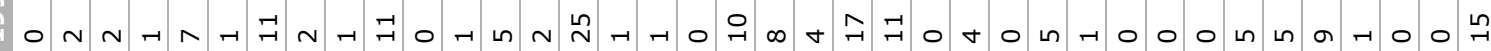

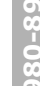

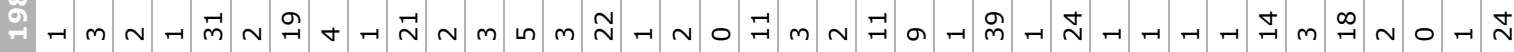

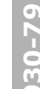
에 $\infty$ 윙ำ

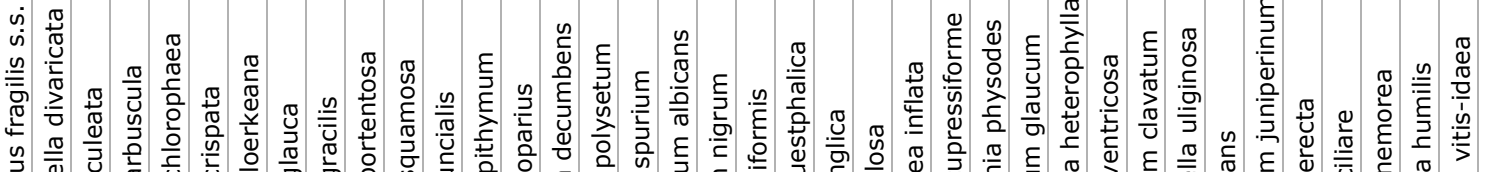

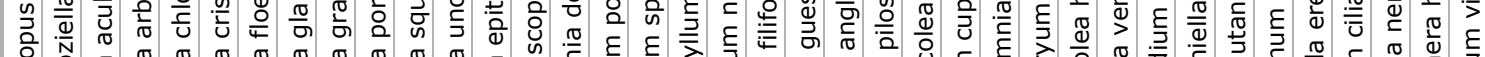

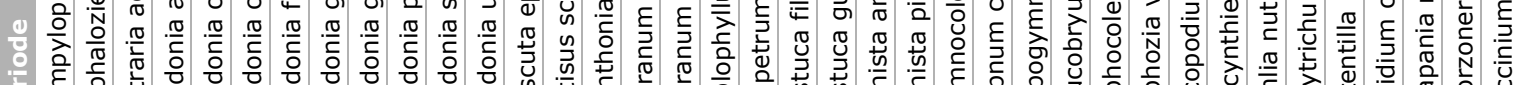

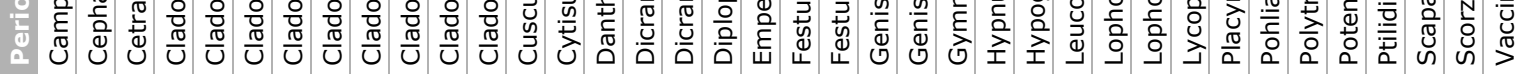




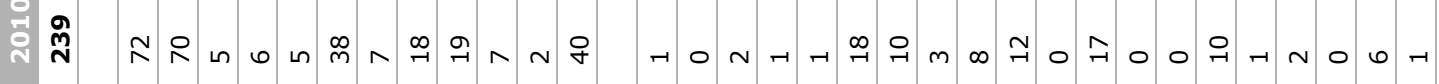

da

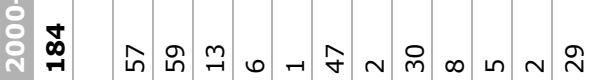

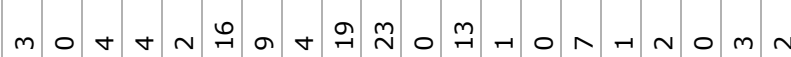

:

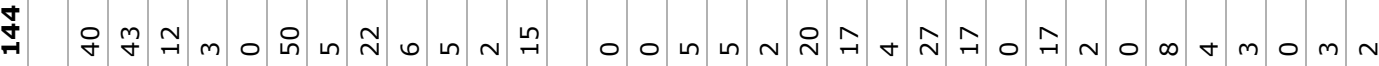

\%

S్ర m

ํํㅇ

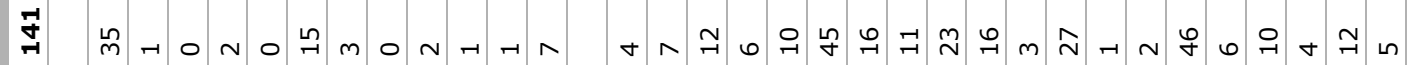

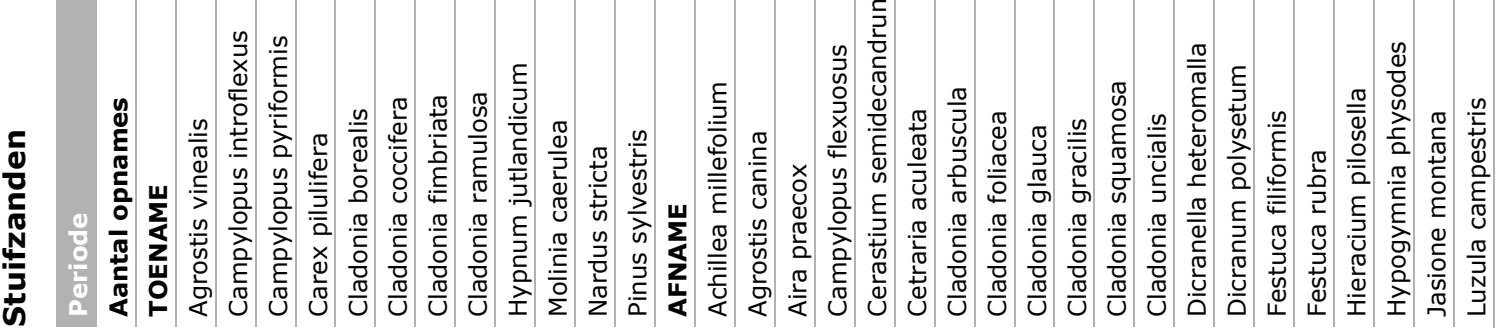


할

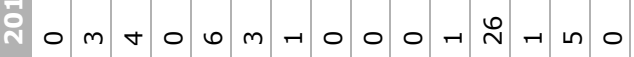

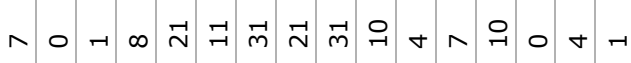

:

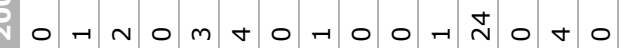

Am na d

¿

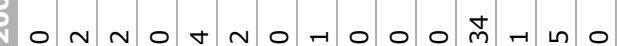

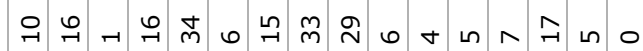

के

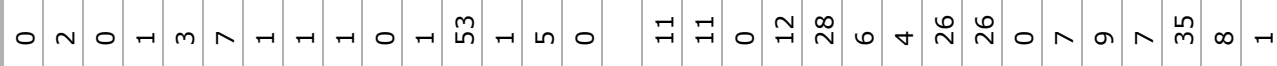

$:$
$\vdots$
$\vdots$
$\vdots$
$\vdots$

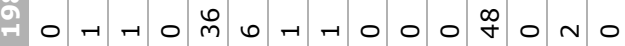

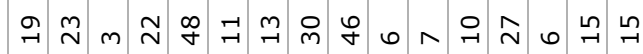

ì Naอน ก ก

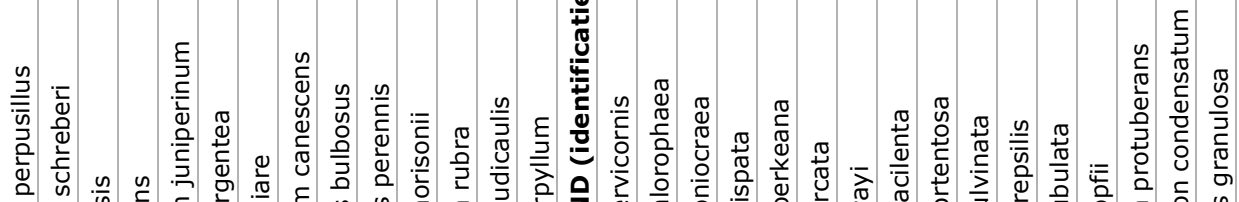

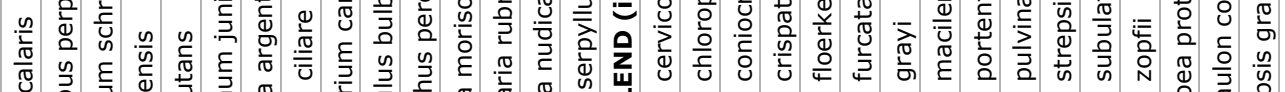

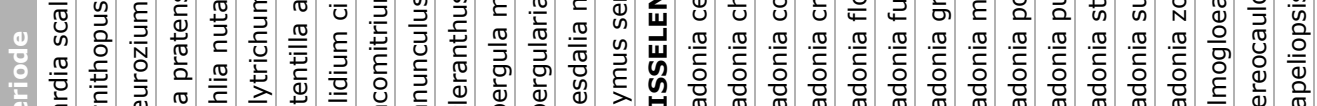

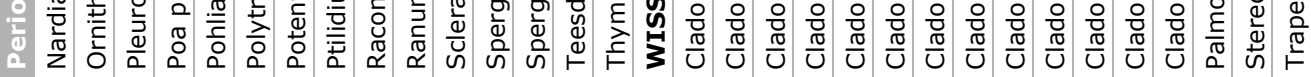




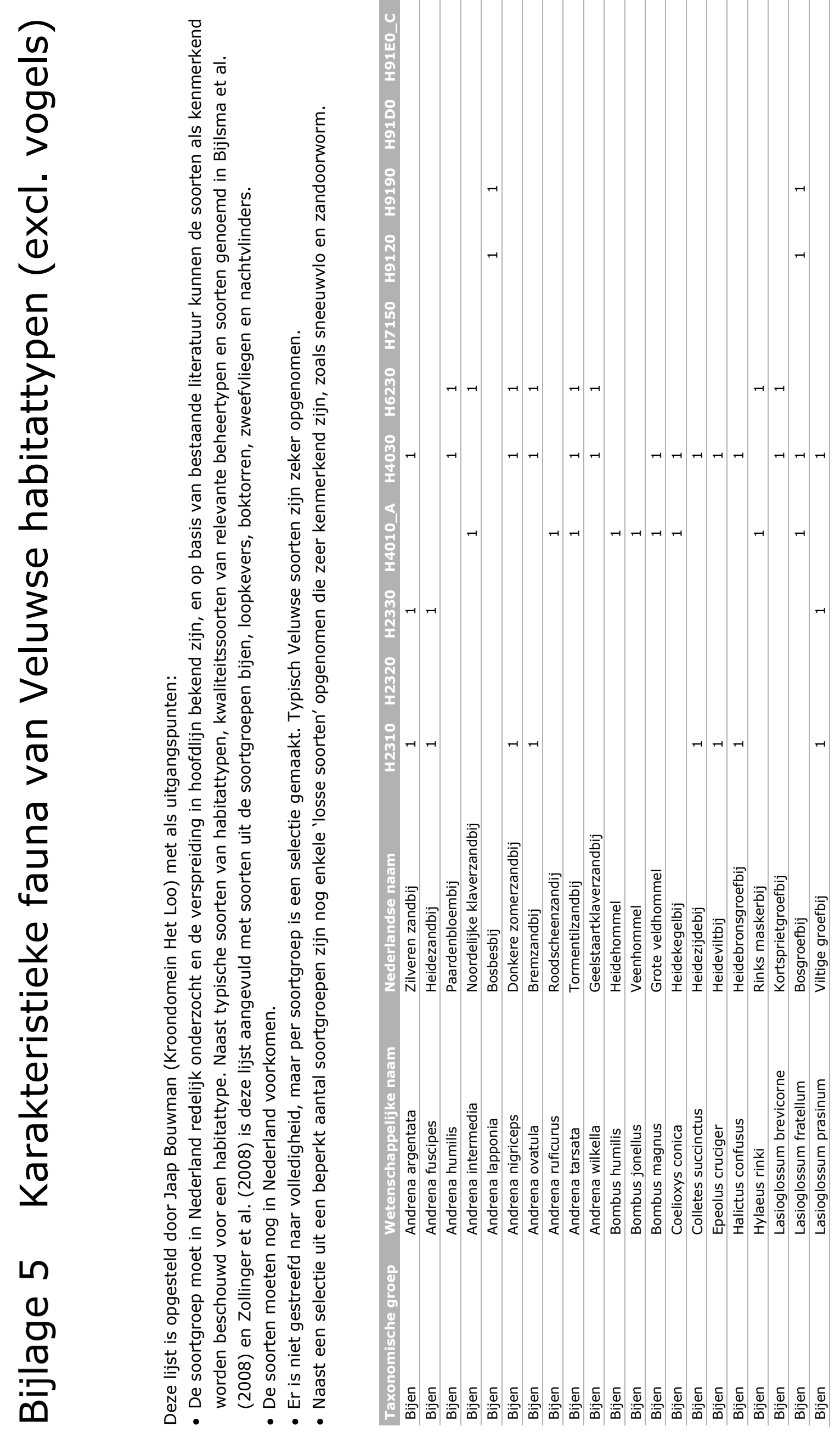




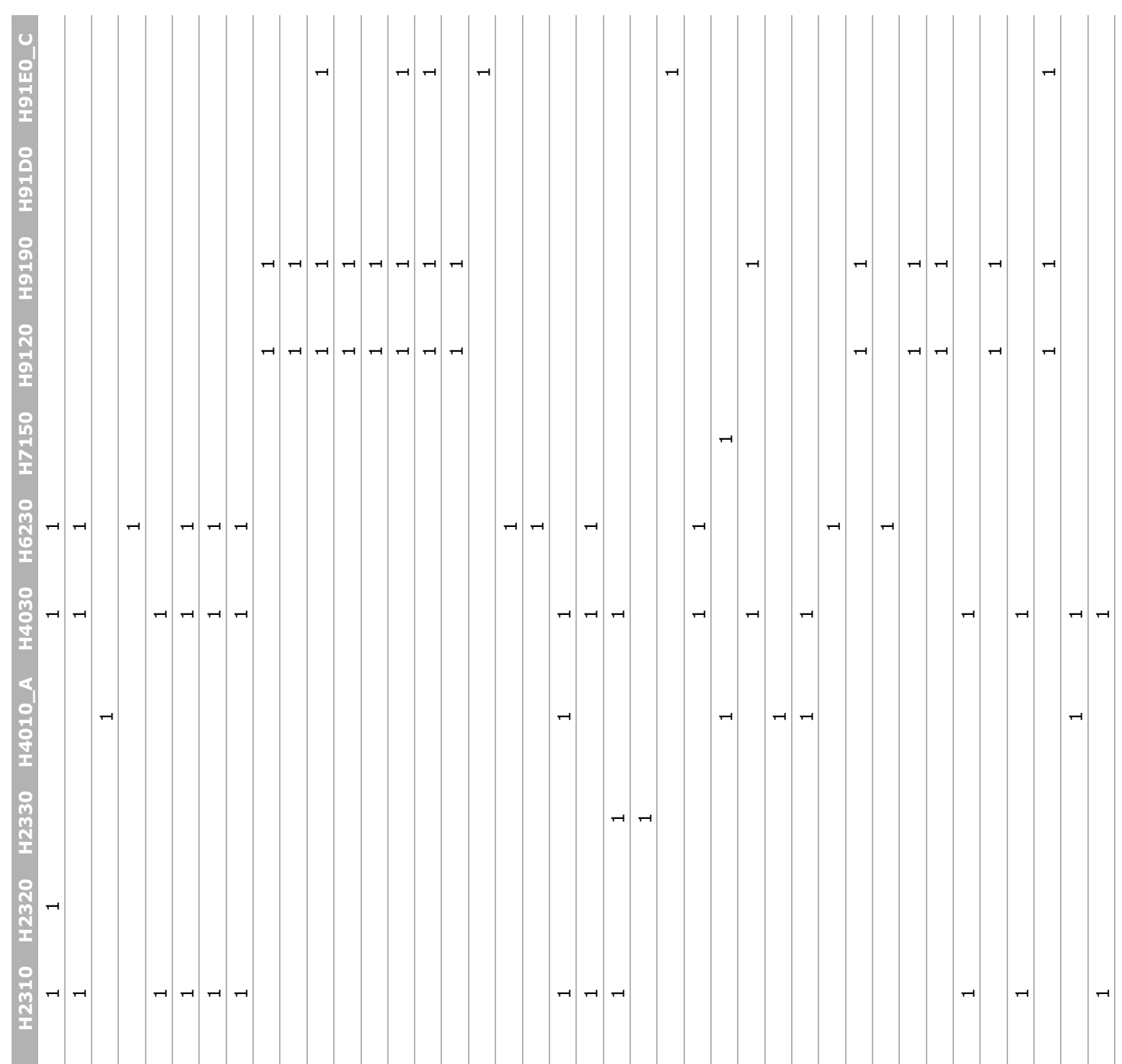

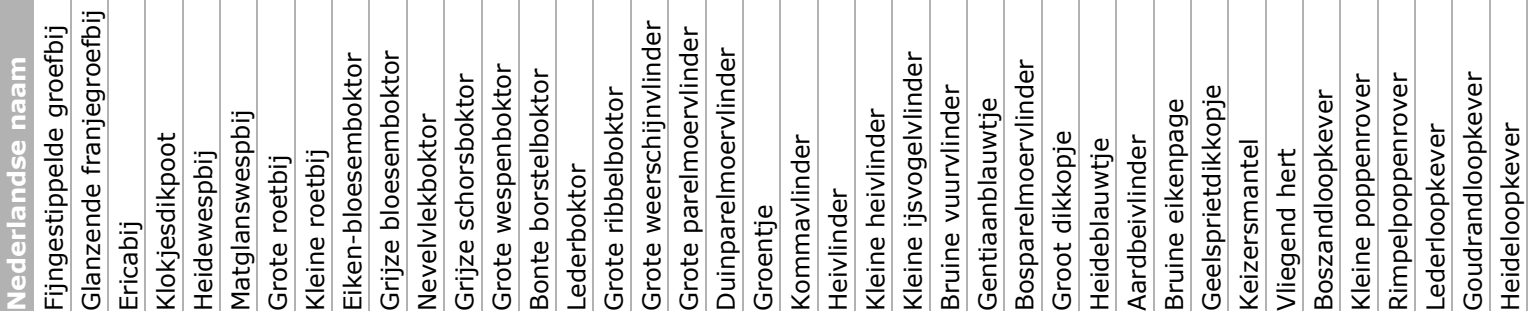

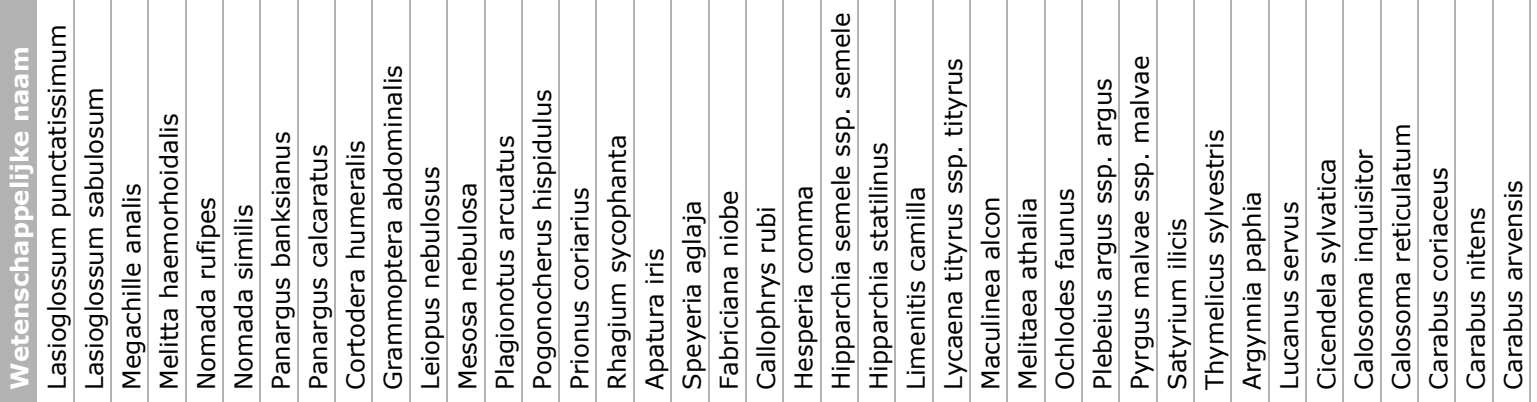

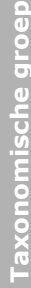

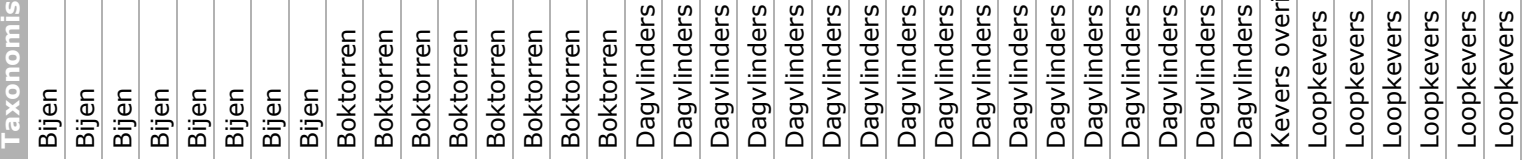




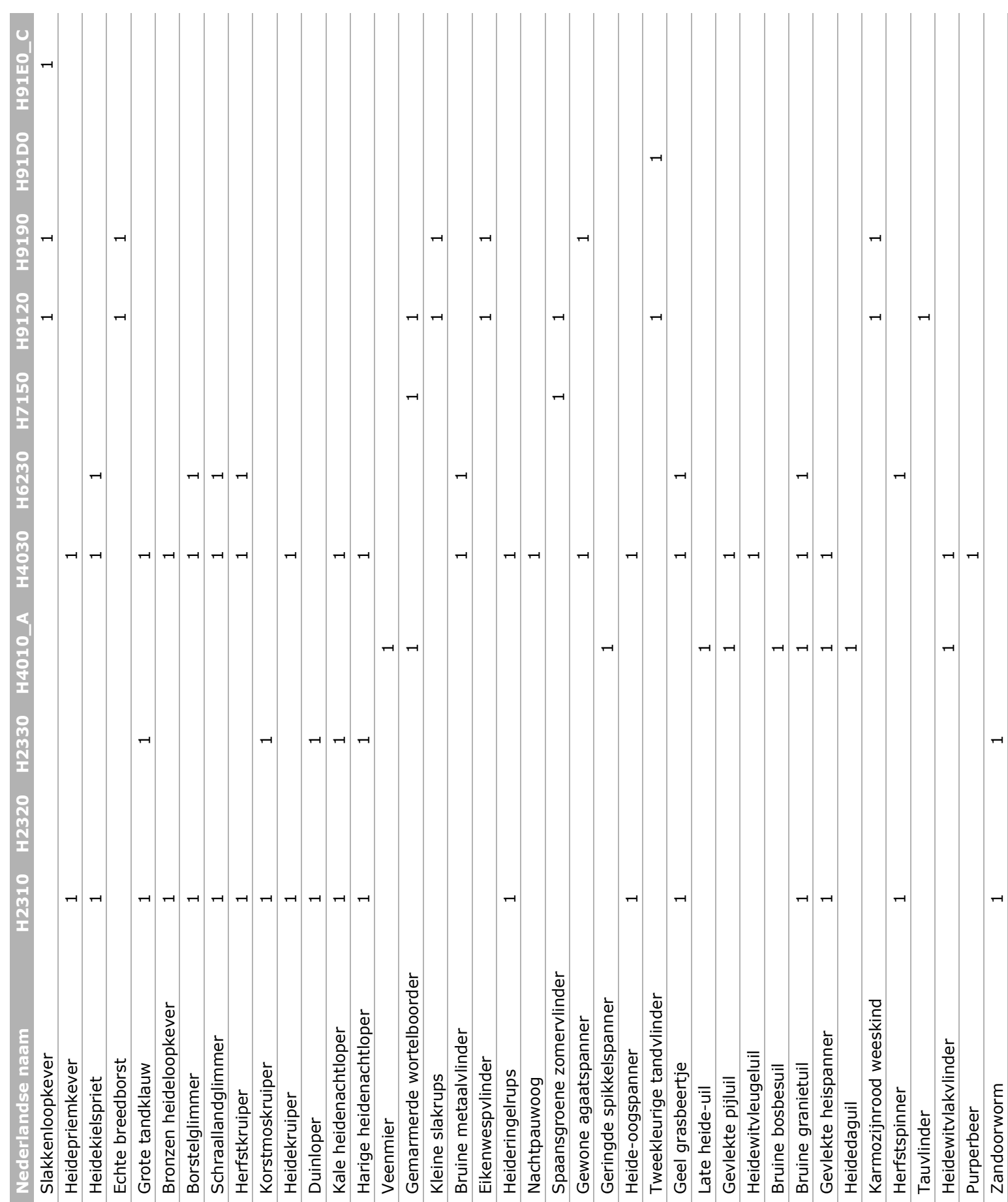

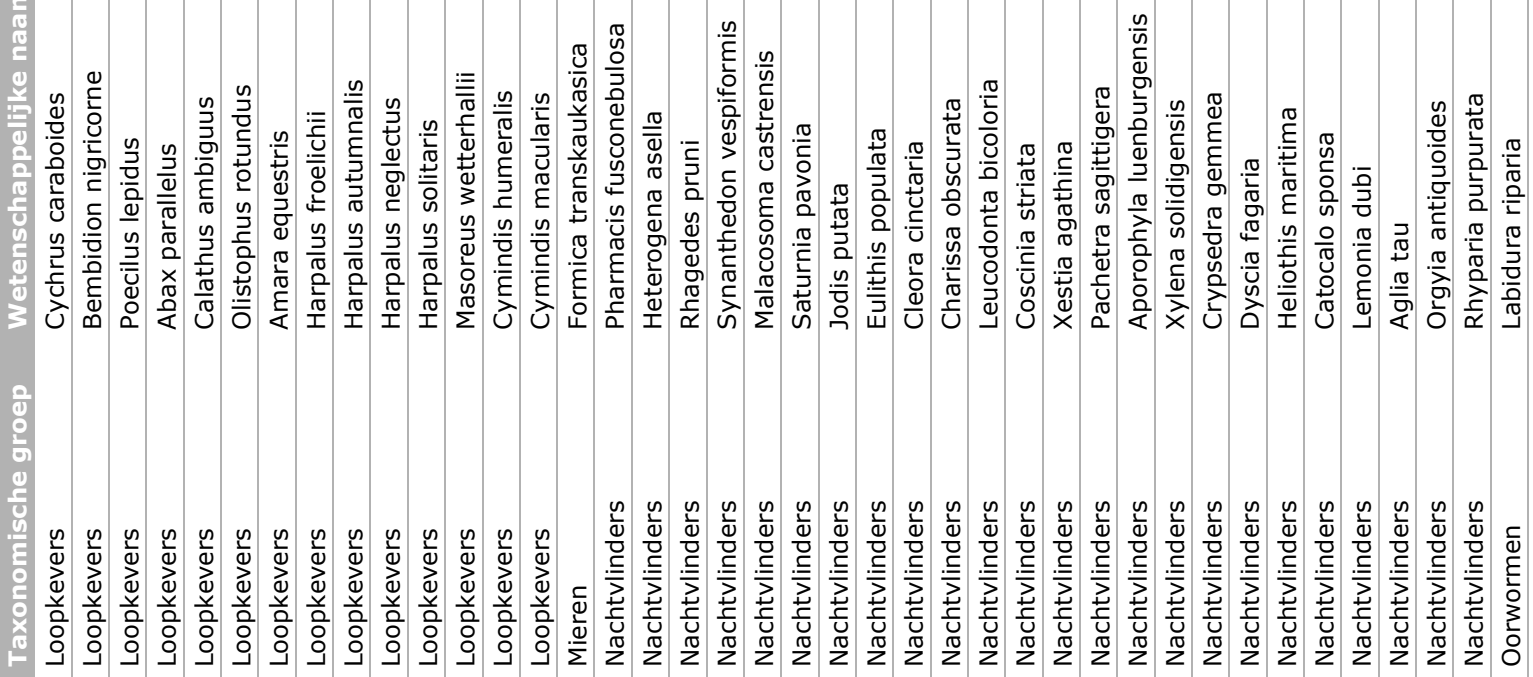




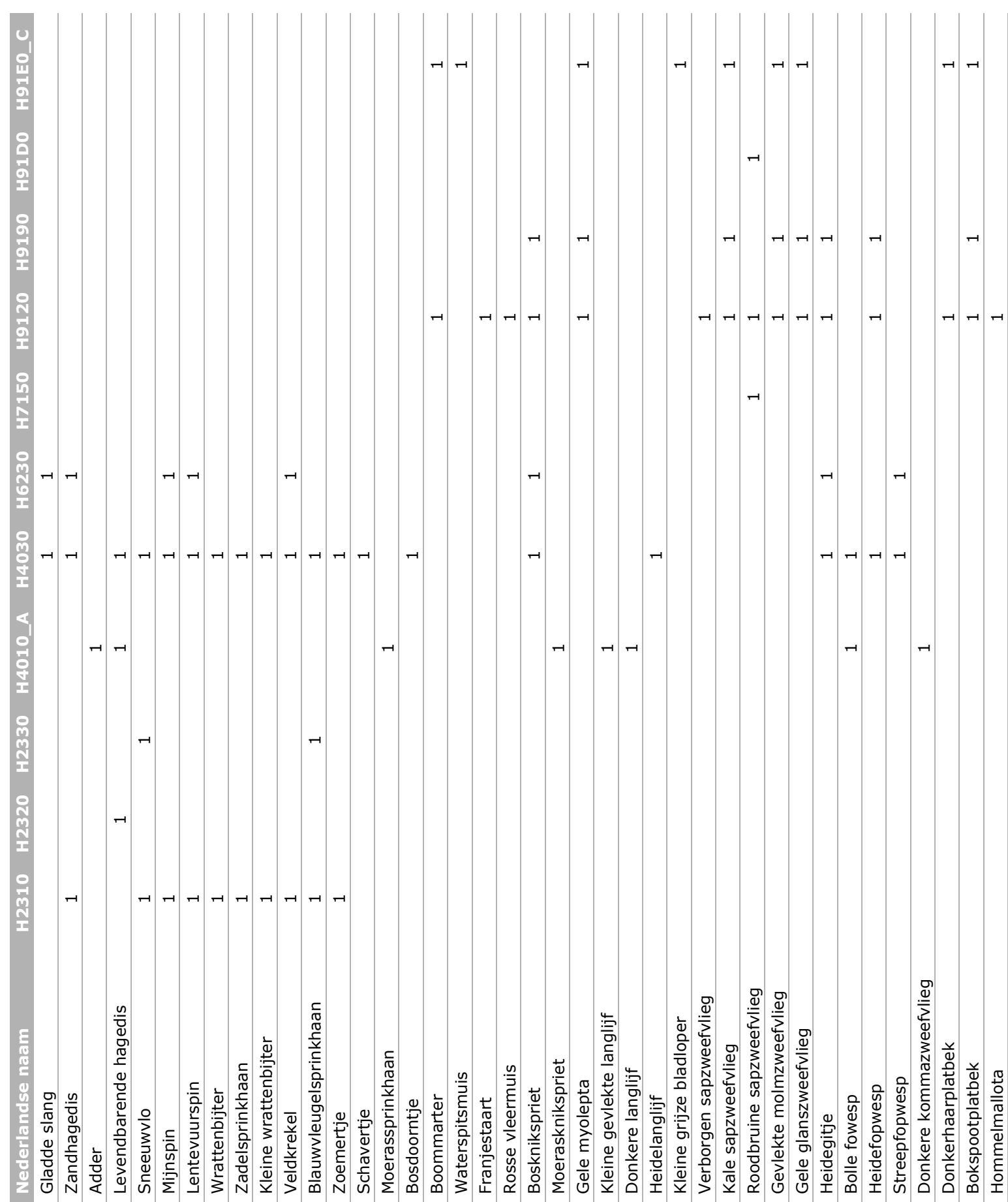

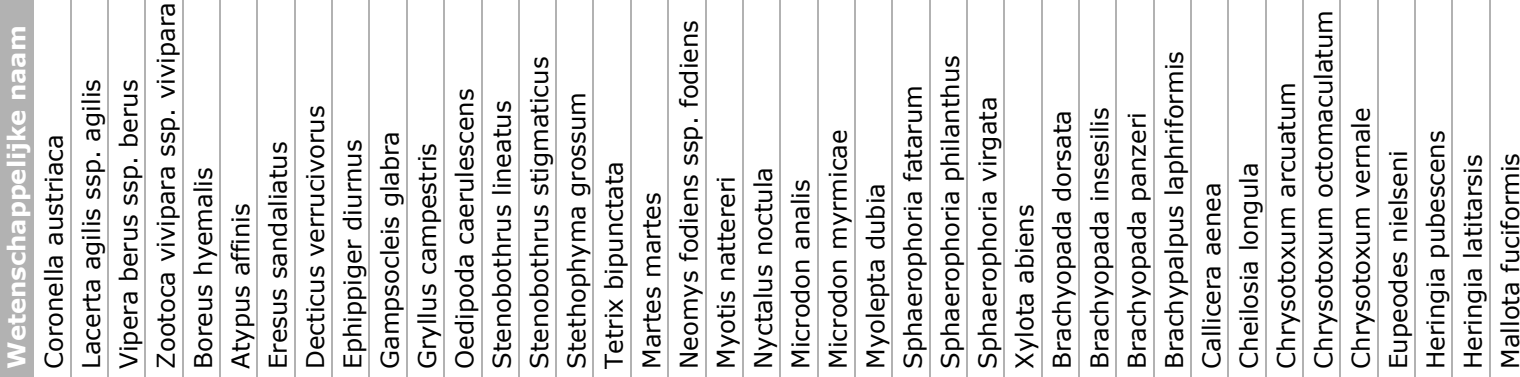

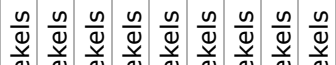

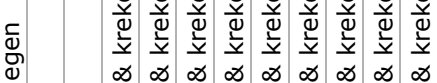

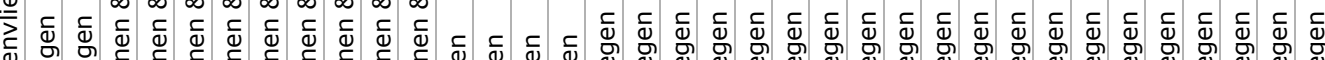

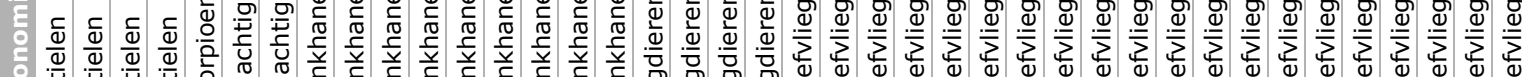

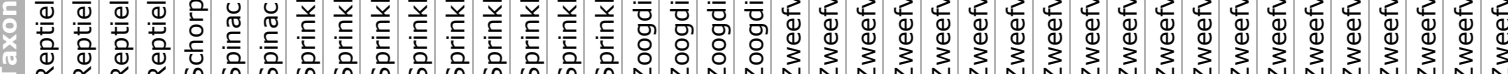




\section{Bijlage 6 Bodemkundige detailkarteringen van de Veluwe}

Deze bijlage geeft nadere informatie over de legenda's van bodemkundige detailkarteringen waarnaar verwezen wordt in Hoofdstuk 6.

\section{B6.1 Kaartmateriaal}

Bij het gebruik van de landelijke kaarten (geomorfologie en bodem) voor de interpretatie in de deelgebieden komen we de volgende beperkingen tegen:

1. De kaartschaal (1:50.000) en de bijbehorende boringsdichtheid laten een gedetailleerde kartering van ecologisch relevante patronen niet toe. Dat geldt met name voor:
a. De variatie in textuur en mineralogische rijkdom in de gestuwde afzettingen (HzGS);
b. De variatie in stuifzanddikte, aard van het stuifzand en de ondergrond binnen stuifzandgebieden (HzS);
c. De variatie in afzettingen en hydrologische positie in beekdalen $(\mathrm{HzB})$;

2. Als gevolg van de onder 1 genoemde beperkingen is deze variatie opgenomen in grotere eenheden die het bereik van de variatie beschrijven, zoals:
a. Textuurcode 30 voor alle grofzandige afzettingen, ongeacht de lemigheid;
b. De eenheden Zd en AS voor stuifzandgronden waarbij geen uitspraak gedaan wordt over de variatie daarbinnen;
c. De associaties $A B z A B v$ en $A B k$ voor beekdalgronden

Hoewel deze generalisatie passend is voor het schaalniveau, ontbreekt daardoor ecologisch relevante informatie. Om die reden is het de moeite waard om, waar mogelijk, gebruik te maken van beschikbare detailkarteringen. In Figuur B6.1 en Tabel B6.1 is aangegeven welke detailkarteringen uit het WENR-archief hier bruikbaar voor kunnen zijn. Wij hebben ons hierbij beperkt tot karteringen van Militaire oefenterreinen, boswachterijen en bosreservaten. Sinds 1965 wordt hierbij een gestandaardiseerde legenda gebruikt (Ten Cate et al., 1995), waardoor de karteringen vanaf dat jaar goed te vergelijken zijn (zie § B6.2). Daarvóór werden andere legenda's gebruikt, soms met afwijkende indelingen voor bijvoorbeeld textuur (zie § B6.3). 


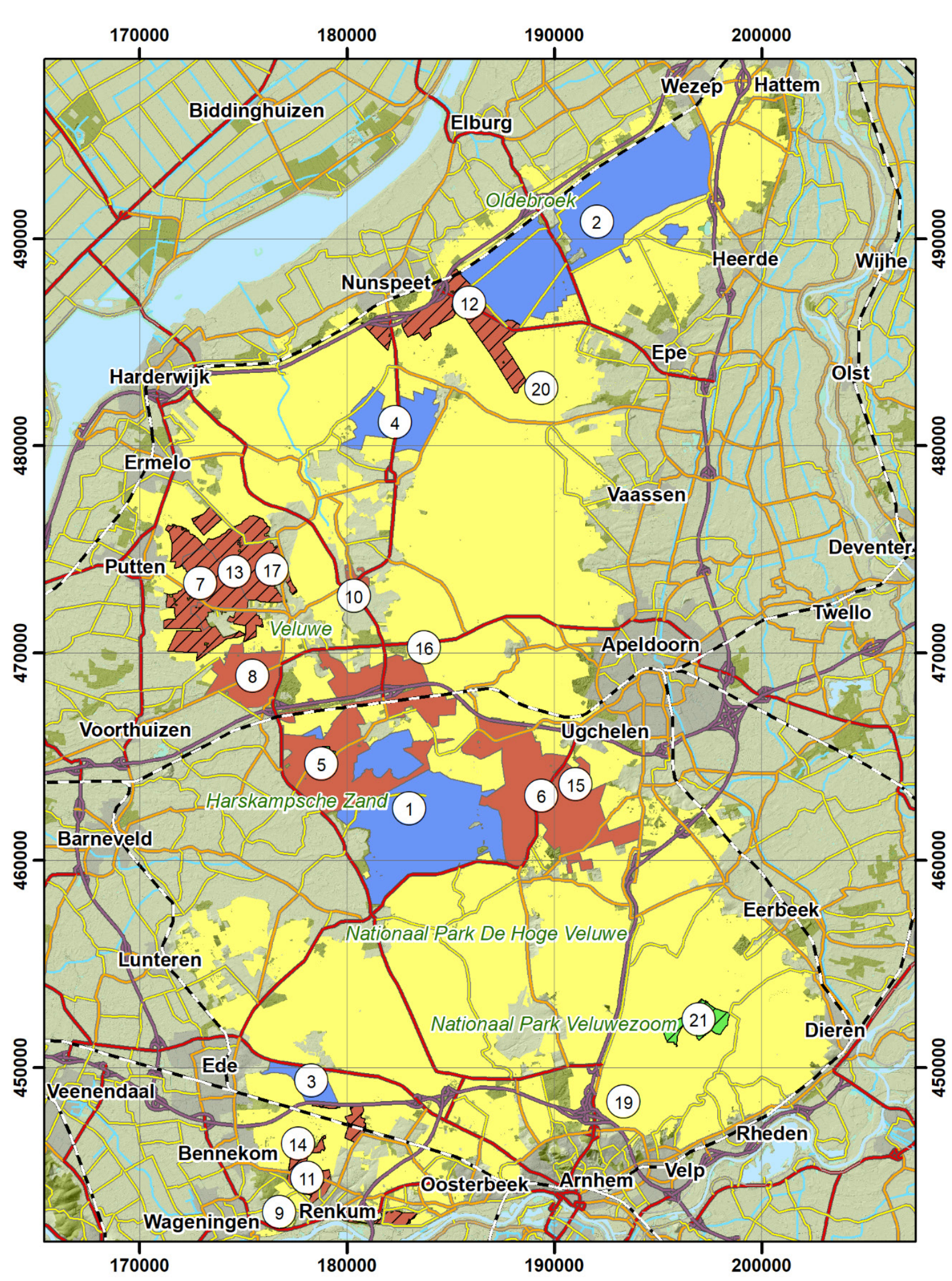

\section{Legenda}

\section{Detailkaarten $\quad \square / \lambda$ Legenda Ten Cate 1995}

$\square$ Bosreservaat

Boswachterij

Militair oefenterrein

Figuur B6.1 Overzicht van relevante detailkarteringen uit het WENR-archief. De nummers corresponderen met de karteringen in Tabel B6.1. 
Tabel B6.1 Gegevens van de relevante detailkarteringen in het WENR-archief (zie Figuur B6.1).

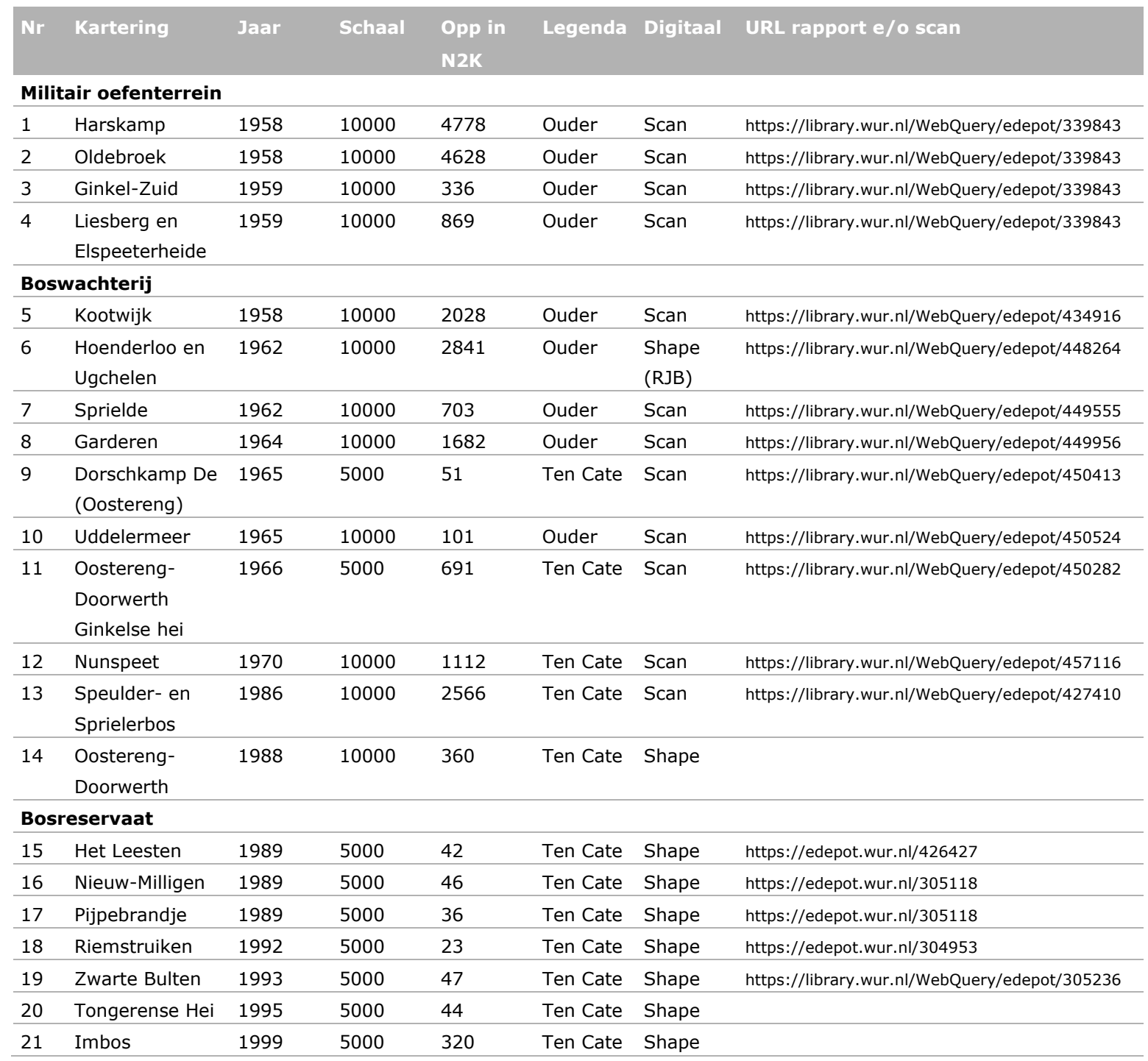

Bij detailkarteringen van voor 2000 werd voor de oriëntatie in het veld vooral gebruikgemaakt van luchtfoto's en topografische kaarten. De betrouwbaarheid van de locatiebepaling en het afgrenzen van kaartvlakken waren sterk afhankelijk van de herkenbaarheid van vormen op luchtfoto's. Soms ging dat heel goed, soms was dat lastiger en lijken kaartvlakken wat verschoven te zijn ten opzichte van de werkelijkheid in het veld. Daar moet bij de interpretatie wel rekening mee gehouden worden. Vanaf circa 2000 zijn nieuwe hulpmiddelen beschikbaar gekomen in de vorm van het AHN voor het herkennen van vormen en gps voor een betere locatiebepaling, hoewel de nauwkeurigheid van gps in bos niet altijd goed is.

\section{B6.2 Interpretatie legenda's vanaf 1965}

Met ingang van 1965 werd bij de toenmalige Stichting voor Bodemkartering (Stiboka) gewerkt met een gestandaardiseerde legenda voor detailkarteringen, wat het vergelijken en interpreteren van deze karteringen vergemakkelijkt. In deze paragraaf beschrijven wij de voor de beoordeling in deelgebieden relevante indelingen. De karteringen waar dit betrekking op heeft, zijn in Figuur B6.1 met een arcering aangegeven.

\section{Textuurindeling}

Binnen de hier besproken FG-eenheden is dit vooral van belang binnen de FG-secties HzG 'Glaciale gebieden' en een deel van HzD 'Dekzandgebieden' om onderscheid te kunnen maken tussen de lemige en leemarme varianten. Tabel B6.2 geeft de zandgrofheidsklassen weer en de relatie met de code van de Bodemkaart van Nederland. Bij gebruik van detailkarteringen is de zandgrofheid niet 
onderscheidend voor de FG-series, wel bij de Bodemkaart van Nederland, omdat bij grofzandige bodems de bodemvorming wordt gebruikt om een inschatting te maken van de lemigheid.

Tabel B6.2 Zandgrofheidsklassen bij zandgronden (eerste cijfer in het cijferdeel van de legendacode) (Naar Ten Cate et al., 1995). De eerste kolom bevat de codes van de enkelvoudige klassen. De volgende kolommen met even getallen bevattende codes voor telkens twee samengevoegde enkelvoudige klassen. De laatste kolom geeft de corresponderende zandgrofheidscode voor de Bodemkaart van Nederland, schaal 1:50.000 (B50K).

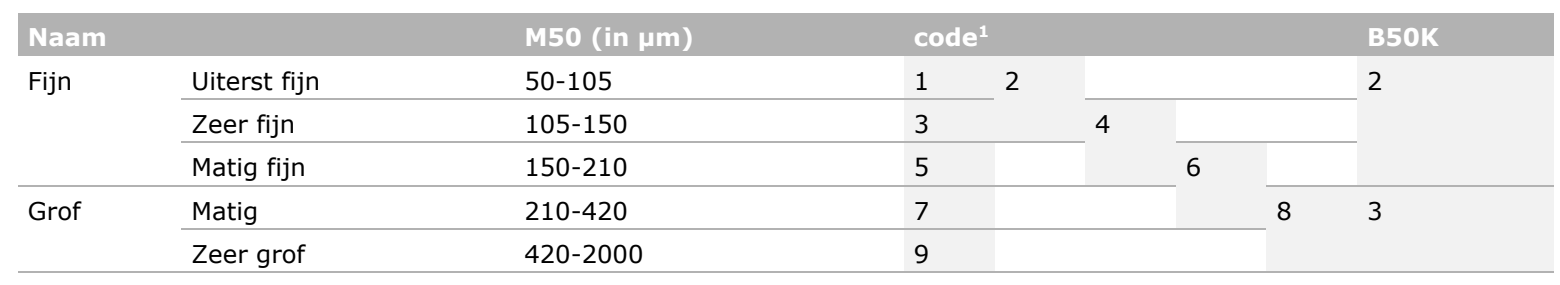

Het leemgehalte is een belangrijke indicator die zeker in gestuwde afzettingen sterk kan variëren. In detailkarteringen is dit vaak met een grote mate van detail uitgekarteerd. In Tabel B6.3 is de indeling van het leemgehalte, het tweede cijfer in de textuurcode voor zandgronden, het enige cijfer bij leemgronden, weergegeven. Omdat een leemgehalte van $20 \%$ een belangrijke ecologische grens is, zou de grens tussen leemarme en lemige series eigenlijk bij $20 \%$ moeten liggen, maar we hanteren hier de grens tussen zwak lemig en sterk lemig (17,5\%). Bodems met leemklasse 4 (bijvoorbeeld Y64) vallen samen met deze grens, maar rekenen wij dan toch maar bij de lemige FG-series.

Tabel B6.3 Leemgehalte bij zandgronden (tweede cijfer in het cijferdeel van de legenda-code) en leemgronden (enige cijfer). (Naar Ten Cate et al., 1995.) In de laatste twee kolommen geven wij aan hoe de lemigheid vertaald moet worden binnen de FG-secties HzG en HzD.

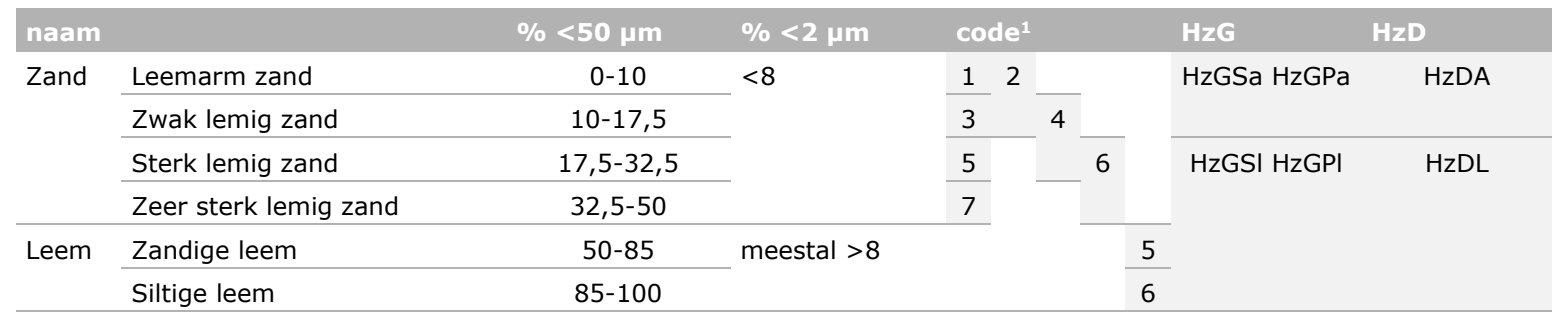

\section{Bodemvorming}

Behalve de textuur is ook de bodemvorming bij detailkarteringen met een grotere mate van detail in kaart gebracht. Om daarom een betere beoordeling van de potenties van een deelgebied te kunnen geven, kan een eventuele detailbodemkaart geïnterpreteerd worden volgens de sleutel in Tabel B6.4. Hierin wordt voor verschillende bodemtypen aangegeven tot welke FG-serie een kaartvlak gerekend kan worden, eventueel afhankelijk van textuur, toevoegingen voor grind of leem en de ligging binnen de FG-secties op de Landschappelijke bodemkaart van de Veluwe. Bij toekenning worden de volgende stappen genomen:

1. Zoek de bodemeenheid op in de eerste kolom, dat kunnen meerdere regels zijn. De stipjes in de codes staan voor weggelaten informatie, bijvoorbeeld over textuur die in de volgende stap wordt beoordeeld.

2. Controleer in de kolommen Grofheid (eerste cijfer textuurcode) en Lemigheid (tweede cijfer textuurcode) de textuurcode.

3. Als op de kaart toevoegingen zijn aangegeven voor grind $(\mathrm{g}$ ) of leem (I) kijken wat van toepassing is:

a. $b=$ toevoeging in de bovengrond, voor de code

b. $\mathrm{o}=$ toevoeging in de ondergrond, achter de code

c. - = voor deze FG-serie sluiten we deze toevoeging uit, bijvoorbeeld geen grind in dekzand

d. Leeg = toevoeging is hier niet onderscheidend 
4. In de laatste kolommen zijn één of meer FG-series aangegeven waar deze bodemeenheid bij hoort:

a. Als bij de FG-series maar één optie is ingevuld deze kiezen (bijvoorbeeld bij $\mathrm{HzO}$ ).

b. Bij meerdere opties controleren wat de FG-sectie is volgens de Landschappelijke bodemkaart van de Veluwe en dan de bijbehorende FG-serie kiezen.

Tabel B6.4 Sleutel voor de vertaling van eenheden van detailbodemkaarten vanaf 1965 naar FGseries. (Voor toelichting, zie tekst.)

\begin{tabular}{|c|c|c|c|c|c|c|c|c|c|c|}
\hline & Textuur & & Toevo & eging & Binnen & FG-sec & cties & & & \\
\hline Bodemeenheid & Grofheid & Lemig-heid & Grind & Leem & HzGS & HzGP & $\mathrm{HzS}$ & HzD & $\mathrm{HzB}$ & $\mathrm{HzO}$ \\
\hline$a V z$ vVz Vz cVz aWz & & & & & $\mathrm{HzBB}$ & $\mathrm{HzBB}$ & & HzDG & $\mathrm{HzBB}$ & \\
\hline$a V z g \vee W z g$ & & & 0 & & $\mathrm{HzBB}$ & $\mathrm{HzBB}$ & & & $\mathrm{HzBB}$ & \\
\hline tZg.. tbZg.. Zg.. tZn.. & $3 \mathrm{t} / \mathrm{m} 6$ & $1 \mathrm{t} / \mathrm{m} 7$ & - & & $\mathrm{HzBD}$ & $\mathrm{HzBD}$ & & $\mathrm{HzDV}$ & $\mathrm{HzBN}$ & \\
\hline tZg.. tbZg.. Zg.. tZn.. & $3 \mathrm{t} / \mathrm{m} 9$ & $1 \mathrm{t} / \mathrm{m} 7$ & bo & & $\mathrm{HzBD}$ & HzBD & & & $\mathrm{HzBN}$ & \\
\hline$z W z z V z$ & & & bo & & $\mathrm{HzDG}$ & HzDG & & HzDG & $\mathrm{HzBN}$ & \\
\hline$a \vee p \vee W p$ & & & & & $\mathrm{HzDR}$ & $\mathrm{HzDR}$ & & $\mathrm{HzDR}$ & $\mathrm{HzBN}$ & \\
\hline$v W p$ & & & o & & HzDR & HzDR & & & HzBN & \\
\hline Hd.. Y.. Zb.. & $3 \mathrm{t} / \mathrm{m} 6$ & $1 \mathrm{t} / \mathrm{m} 3$ & - & & $\mathrm{HzGSa}$ & $\mathrm{HzGPa}$ & & HzDA & & \\
\hline Hn.. tZn.. tZg.. & $3 \mathrm{t} / \mathrm{m} 6$ & $1 \mathrm{t} / \mathrm{m} 3$ & - & & $\mathrm{HzGSa}$ & $\mathrm{HzGPa}$ & & $\mathrm{HzDV}$ & $\mathrm{HzBN}$ & \\
\hline Hn.. tZn.. tZg.. & $7 \mathrm{t} / \mathrm{m} 9$ & $1 \mathrm{t} / \mathrm{m} 3$ & - & & $\mathrm{HzGSa}$ & $\mathrm{HzGPa}$ & & & $\mathrm{HzBN}$ & \\
\hline Hn.. tZn.. tZg.. & $3 \mathrm{t} / \mathrm{m} 9$ & $1 \mathrm{t} / \mathrm{m} 3$ & bo & & $\mathrm{HzGSa}$ & $\mathrm{HzGPa}$ & & & $\mathrm{HzBN}$ & \\
\hline Hd.. Y.. & $7 \mathrm{t} / \mathrm{m} 9$ & $1 \mathrm{t} / \mathrm{m} 3$ & - & & $\mathrm{HzGSa}$ & $\mathrm{HzGPa}$ & & & & \\
\hline Hd.. Y.. & $3 \mathrm{t} / \mathrm{m} 9$ & $1 \mathrm{t} / \mathrm{m} 3$ & bo & & $\mathrm{HzGSa}$ & $\mathrm{HzGPa}$ & & & & \\
\hline Hd.. Y.. & $3 \mathrm{t} / \mathrm{m} 6$ & $4 \mathrm{t} / \mathrm{m} 7$ & - & & $\mathrm{HzGSI}$ & $\mathrm{HzGPI}$ & & $\mathrm{HzDL}$ & & \\
\hline Hd.. Y.. & $3 \mathrm{t} / \mathrm{m} 6$ & $1 \mathrm{t} / \mathrm{m} 7$ & - & o & $\mathrm{HzGSI}$ & $\mathrm{HzGPI}$ & & $\mathrm{HzDL}$ & & \\
\hline Hn.. tZn.. tZg.. & $7 \mathrm{t} / \mathrm{m} 9$ & $4 \mathrm{t} / \mathrm{m} 7$ & - & & $\mathrm{HzGSI}$ & $\mathrm{HzGPI}$ & & $\mathrm{HzDV}$ & $\mathrm{HzBN}$ & \\
\hline Hn.. tZn.. tZg.. & $3 \mathrm{t} / \mathrm{m} 9$ & $4 \mathrm{t} / \mathrm{m} 7$ & bo & & $\mathrm{HzGSI}$ & $\mathrm{HzGPI}$ & & $\mathrm{HzDV}$ & $\mathrm{HzBN}$ & \\
\hline L & & 56 & & & $\mathrm{HzGSI}$ & HzGPI & & & & \\
\hline Y.. Hd.. & $3 \mathrm{t} / \mathrm{m} 9$ & $4 \mathrm{t} / \mathrm{m} 7$ & bo & & $\mathrm{HzGSI}$ & HzGPI & & & & \\
\hline Y.. Hd.. Zb.. & $3 \mathrm{t} / \mathrm{m} 9$ & $1 \mathrm{t} / \mathrm{m} 7$ & & 0 & $\mathrm{HzGSI}$ & $\mathrm{HzGPI}$ & & & & \\
\hline Zb.. & $3 \mathrm{t} / \mathrm{m} 6$ & $1 \mathrm{t} / 3$ & & & & & & HzDA & & \\
\hline$z W z$ & & & - & & & & & $\mathrm{HzDG}$ & & \\
\hline$z V p z V z$ zWp zWz & & & & & & & & $\mathrm{HzDV}$ & $\mathrm{HzBN}$ & \\
\hline$z W p$ pVp zVz & & & 0 & & & & & & $\mathrm{HzBN}$ & \\
\hline Rd.. Rn.. pRd.. pRn.. hW. hV. & & & & & & & & & $\mathrm{HzBV}$ & \\
\hline$a Z . . b Z . . c Z .$. & & & & & & & $\mathrm{HzSD}$ & & & \\
\hline aZ..p bZ..p cZ..p Zd..p & & & & & & & $\mathrm{HzSF}$ & & & \\
\hline aZ..z bZ..z cZ..z Zd..z & & & & & & & $\mathrm{HzSF}$ & & & \\
\hline Z.. Zn.. & & & & & & & $\mathrm{HzSL}$ & & & \\
\hline bEZ.. cY.. bZd.. cbZg.. & & & & & & & & & & $\mathrm{HzOB}$ \\
\hline zEZ.. cHd.. cHn.. cZd.. cZg.. cZn.. HZ & & & & & & & & & & $\mathrm{HzOZ}$ \\
\hline
\end{tabular}

\section{Detailinformatie stuifzandlandschap}

Afgezien van het feit dat stuifzandreliëf veel kleinschaliger is dan de landelijke kaarten kunnen weergeven, zijn zeker de samengestelde eenheden HzSDF en HzSX onvoldoende gedetailleerd om uitspraken te doen over de natuurpotenties op lokaal niveau. Voor interpretatie van een specifiek terrein kan lokale informatie gebruikt worden. Voor veel bossen en natuurgebieden zijn gedetailleerde bodemkaarten beschikbaar waar het onderscheid wel goed te maken is. Voor de legenda voor detailkarteringen verwijzen wij naar Ten Cate et al. (1995), naar de indeling voor 'Grootschalige karteringen'. De belangrijkste kenmerken zijn:

- Afgestoven bodems in uitgestoven laagtes worden aangeduid met een code Z.. waarbij op de positie van de punten een textuurcode gegeven wordt. Bijvoorbeeld Z53: Afgestoven bodem in zwak lemig matig fijn zand.

- Opgestoven bodems, waarbij binnen $180 \mathrm{~cm}$-mv pleistoceen materiaal of veen wordt aangetroffen worden aangeduid met een letter achter de textuurcode die aangeeft wat de aard van het materiaal onder het stuifzandpakket is:

- z: zand zonder podzol (opgestoven stuifzand op een eerder afgestoven profiel); 
- p: zand met een duidelijke humuspodzol-B (overstoven);

- $\mathrm{m}$ : zand met een duidelijke moderpodzol-B (overstoven);

- v: veen (bij overstoven vennen) (overstoven);

- wordt dit materiaal tussen 100 en $180 \mathrm{~cm}$-mv aangetroffen wordt een d voor de bodemcode geplaatst;

- Voorbeeld: bZ51p: 40-100 cm zeer en matig humusarm, leemarm, matig fijn stuifzand op een humuspodzolprofiel.

- Bij ondergestoven bodems is het stuifzandpakket dikker dan $180 \mathrm{~cm}$. Hierbij wordt géén lettertoevoeging achter de code gegeven, bijvoorbeeld: aZ31: meer dan $180 \mathrm{~cm}$ uiterst en zeer humusarm, leemarm, zeer fijn stuifzand.

- Het humusgehalte van het stuifzand varieert sterk, afhankelijk van de snelheid waarmee de verstuiving plaatsvindt en de mate van begroeiing op de plaats waar het stuifzand accumuleert. Het is ook een belangrijk kenmerk voor de natuurpotenties. Er worden bij de opgestoven en overstoven bodems drie organischestofklassen onderscheiden voor het stuifzand:

- a: uiterst en zeer humusarm;

- b: zeer en matig humusarm;

- c: matig humusarm en matig humeus.

Ook het raadplegen van het AHN kan veel extra informatie bieden, omdat het reliëf een duidelijk kenmerk is van de FG-series binnen de stuifzandgebieden. Bij het ontbreken van een detailkartering is het raadzaam zelf een aantal boringen of een kartering uit te voeren.

\section{B6.3 Interpretatie legenda's ouder dan 1965}

Voor de legenda's van karteringen ouder dan 1965 werden legenda's gehanteerd die nog in ontwikkeling waren. Ook kwam het vaak voor dat legendaeenheden een volgnummer kregen met verwijzing naar de beschrijving. Dat maakt dat het wat meer moeite kost om deze kaarten te interpreteren. Daar staat tegenover dat veel van die karteringen wel zeer gedetailleerd zijn uitgevoerd, met veel aandacht voor de landschappelijke variatie. Hierdoor is het zeker de moeite waard om deze kaarten bij de beoordeling te betrekken. Een voorbeeld is de kartering van de boswachterijen Hoenderloo en Ugchelen (Van Lynden 1962). Hieronder geven wij enige handreikingen bij de interpretatie.

\section{Geologie}

Vaak zijn de eenheden verbonden aan de geologie of geomorfologie ter plaatse. In het rapport is dan aangegeven: 'Gestuwd preglaciaal', 'Dekzand op gestuwd preglaciaal', 'niveao-fluviaal', 'in droogdalen' etc. Dit kan behulpzaam zijn bij het vinden van de juiste FG-serie.

\section{Textuurindeling}

De textuur wordt in vergelijkbare termen (zandgrofheid en lemigheid) beschreven als in de latere karteringen, maar wijkt daar soms ook van af. In de kartering van de boswachterijen Hoenderloo en Ugchelen wordt met de term 'matig fijnzandig' de fractie 150-300 $\mu$ m bedoeld, wat in de huidige legenda overeenkomt met matig fijn tot matig grof (zie Tabel B6.2). Voor lemigheid wordt de term 'niet lemig' gebruikt voor leemarm en 'lemig' voor wat nu aangeduid wordt als 'sterk lemig' en 'zeer sterk lemig'. Door in het begeleidende rapport (zie downloadlink in Tabel B6.1) de omschrijving van de eenheden uit de legenda te vergelijken met de tabellen B6.2 en B6.3, kan de interpretatie verder volgens de sleutel in Tabel B6.4 uitgevoerd worden.

\section{Bodemvorming}

De benamingen voor de bodemvorming komen in grote lijn wel overeen met de huidige, maar er zijn ook verschillen. Voor podzolgronden worden de benamingen 'humuspodzolgrond' en 'humusijzeropodzolgrond' gehanteerd. De eerste komt overeen met 'veldpodzolgrond' in bodems met grondwaterinvloed en 'haarpodzolgrond' in bodems zonder grondwaterinvloed, de tweede met 'moderpodzolgrond'. Bij de stuifzandgronden worden alle kenmerken zoals beschreven in de vorige paragraaf in de beschrijving meegenomen, waardoor vertaling ook goed mogelijk is. 


\section{Bijlage 7 Nutriëntenvoorraden groeiplaatstypen}

Kenmerken van nutriëntenvoorraden en zuurbuffercapaciteit van groeiplaatsen zijn niet opgenomen in de beoordelingsformats van habitattypen en leefgebieden, omdat deze kenmerken praktisch niet zijn te beoordelen voor deelgebieden in het kader van de Veluwse herstelprogramma's. Toch zijn deze kenmerken belangrijk voor behoud en (her)vestiging van flora en de kwaliteit van leefgebied van fauna. Deze bijlage geeft achtergrondinformatie over nutriëntenvoorraden en zuurbuffercapaciteit van groeiplaatstypen die in het kader van een onderzoek naar houtoogst op de bodemvruchtbaarheid is bijeengebracht (Bonten et al., 2015). De gehanteerde indeling voor groeiplaatstypen staat in Tabel B7.1, waarbij groeiplaatstypen zijn vertaald naar voor de Veluwe gehanteerde FG-series.

Tabel B7.1 Onderscheiden groeiplaatstypen voor het onderzoek naar Houtoogst en bodemvruchtbaarheid (Bonten et al., 2015), voor zover relevant voor de landschappelijke bodemkaart van de Veluwe.

\begin{tabular}{|c|c|c|c|}
\hline \multicolumn{2}{|c|}{ Groeiplaatstype } & \multirow{2}{*}{$\begin{array}{l}\text { Bodemtypen } \\
1: 50.000\end{array}$} & \multirow[t]{2}{*}{ FG-Serie Veluwe } \\
\hline & & & \\
\hline GPL01 & $\begin{array}{l}\text { Droge mineraalrijke zandgronden op overwegend leemhoudende } \\
\text { stuwwallen }\end{array}$ & Y23, Y30 & HzGSI, HzGPI \\
\hline GPL02 & Lössleemgronden op leemhoudende stuwwallen & Ld5, Ln5, Ld6, Ln6 & HzGSI \\
\hline GPL03 & $\begin{array}{l}\text { Atmotrofe droge basenarme zandgronden op Puinwaaiers en leemarme } \\
\text { stuwwallen }\end{array}$ & $\mathrm{Hd} 30$ & HzGSa, HzGPa \\
\hline GPL05 & Initiële droge basenarme zandgronden in landduinen & $\mathrm{Zd} 21$ & $\mathrm{HzSD}, \mathrm{HzSF}$ \\
\hline GPL06 & $\begin{array}{l}\text { Atmotrofe droge basenarme zandgronden in overwegend leemarme } \\
\text { droge dekzand gebieden }\end{array}$ & $\mathrm{Hd} 21$ & HzDA \\
\hline GPL07 & Atmotrofe vochtige zandgronden in Vochtige dekzandlaagten & $\mathrm{Hn} 21$ & $\mathrm{HzDV}$ \\
\hline GPL11 & Hoge zandgronden met een zwart bouwlanddek & $\begin{array}{l}\text { zEZ21, zEZ23, } \\
\text { cHn21, cHn23, } \\
\text { cHd21, cHd23 }\end{array}$ & $\mathrm{HzOZ}$ \\
\hline
\end{tabular}

De gemiddelde CEC in mmolc/ $\mathrm{m}^{2}$, belangrijk voor de zuurbuffercapaciteit, is samengevat in Figuur B7.1 en voorraden van verschillende nutriënten in Tabel B7.2. (Zie Bonten et al., 2015) voor achtergronden bij de onderliggende berekeningen.) 


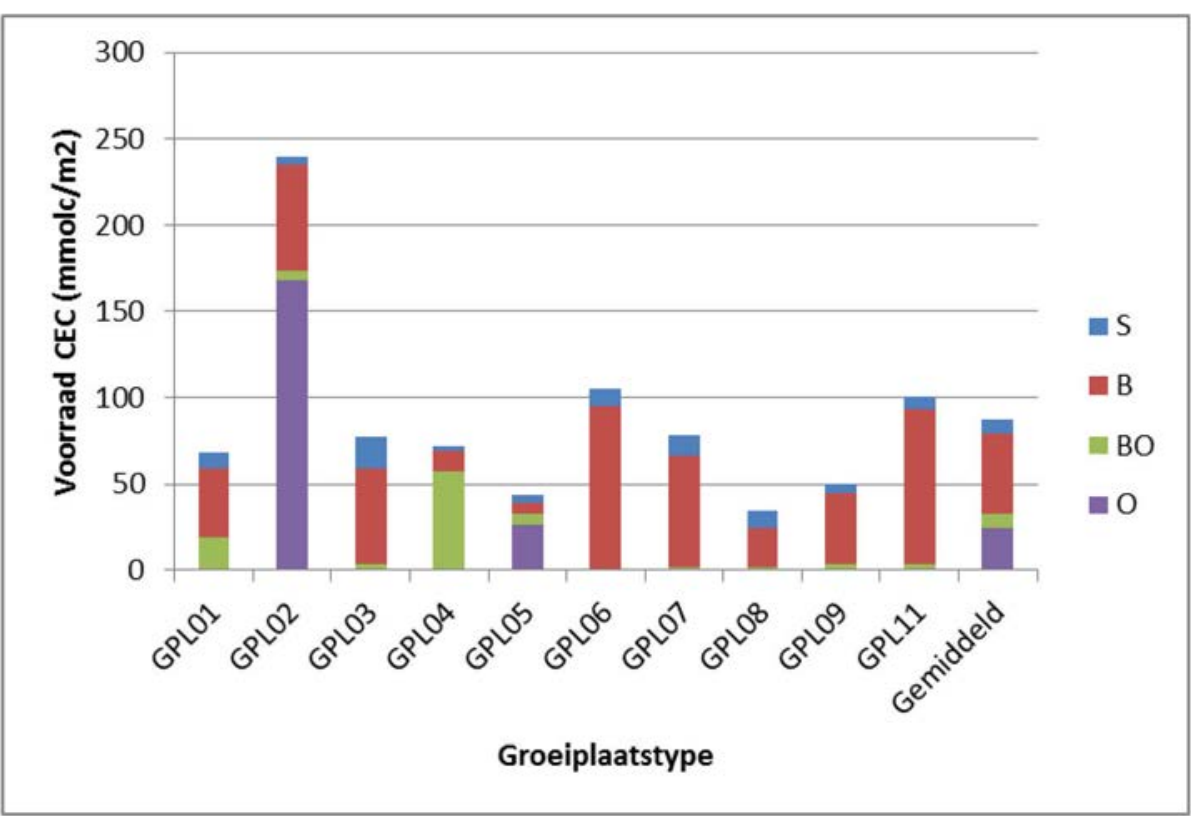

Figuur B7.1 Bijdrage per horizontgroep aan de totale CEC van het profiel, gemiddeld per groeiplaatstype. Voor groeiplaatstypen zie Tabel B7.1. S: strooisellaag; B: bovengronden; BO: overgangshorizonten; O: ondergrond. (Uit Bonten et al., 2015).

Tabel B7.2 Mediane voorraden van nutriënten per groeiplaatstype (kg/ha). Zie Tabel 4.2 voor koppeling groeiplaatstypen en FG-series Veluwe. (Uit Bonten et al., 2015).

\begin{tabular}{|c|c|c|c|c|}
\hline Groeiplaats & $\mathrm{Ca}$ & $\mathrm{Mg}$ & $\mathbf{K}$ & $\mathbf{P}$ \\
\hline GPL02 & 1762 & 184 & 711 & 466 \\
\hline GPL04 & 3351 & 372 & 587 & 462 \\
\hline GPL05 & 1224 & 325 & 615 & 428 \\
\hline GPL07 & 280 & 247 & 436 & 653 \\
\hline GPL08 & 303 & 307 & 437 & 619 \\
\hline GPL09 & 1045 & 290 & 470 & 533 \\
\hline GPL10 & 3214 & 397 & 592 & 605 \\
\hline
\end{tabular}

Nutriënten die door uitspoeling en/of uitputting van de bodem zijn verdwenen, kunnen door depositie en verwering van mineralen deels aangevuld worden. Depositie van $\mathrm{Ca}, \mathrm{Mg}$ en $\mathrm{K}$ is onafhankelijk van de FG-series en voor de hele Veluwe ongeveer gelijk (Bonten et al., 2015; Van Jaarsveld, 2010). Depositie van $P$ is moeilijk te schatten, maar wordt geschat op $0.6 \mathrm{~kg} / \mathrm{ha} / \mathrm{jaar}$. Verwering kan wel verschillen tussen de FG-series. Door Bonten et al. (2015) is een schatting gemaakt van de verweringssnelheden bij verschillende typen moedermateriaal en bij een referentie-pH zoals die onder bos voorkomt (Tabel B7.3). Voor P was geen goede schatting te maken.

Tabel B7.3 Verweringssnelheden van kationen voor de verschillende verweringsklassen, gekoppeld aan FG-series.

\begin{tabular}{|c|c|c|c|c|c|c|c|}
\hline \multirow[t]{2}{*}{ Verweringsklasse } & \multicolumn{3}{|c|}{$\begin{array}{l}\text { Verweringsnelheid } \\
\text { (bij pH_ref) (kg/ha/jr) }\end{array}$} & \multirow[t]{2}{*}{ PH_ref } & \multirow[t]{2}{*}{$\alpha$} & \multirow[t]{2}{*}{$\begin{array}{l}\text { Groeiplaats- } \\
\text { type }\end{array}$} & \multirow[t]{2}{*}{ FG-Serie } \\
\hline & $\mathrm{Ca}$ & $\mathrm{Mg}$ & K & & & & \\
\hline SR (basenrijk zand) & 2.2 & 3.3 & 2.5 & 3.5 & 0,5 & 1,11 & HzGSI HzGPI HzO \\
\hline L (leemgronden) & 4.8 & 1.6 & 0.6 & 4.9 & 0,6 & 2 & HzGSI met Ld \\
\hline
\end{tabular}




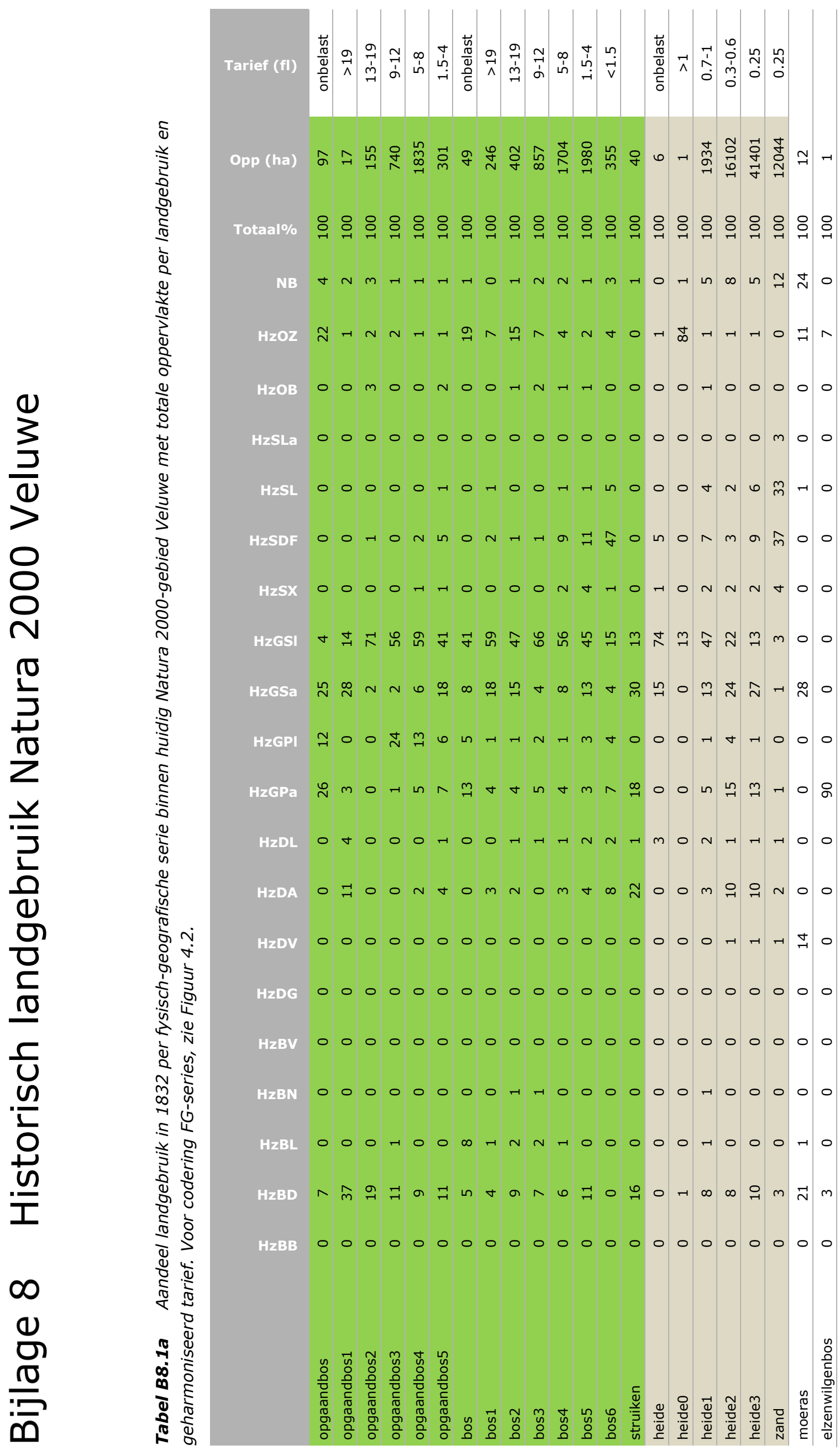




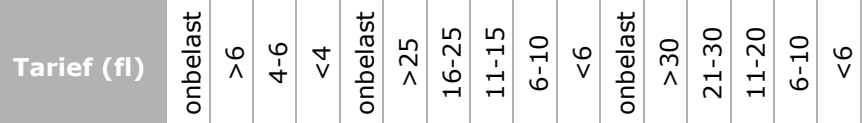

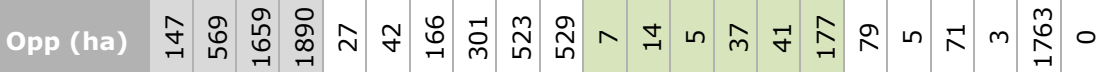

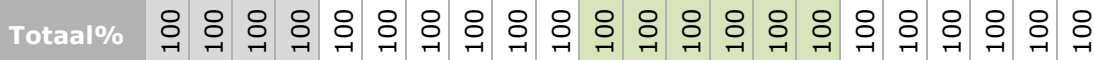

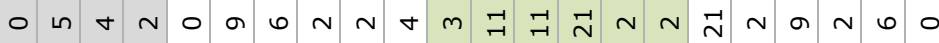

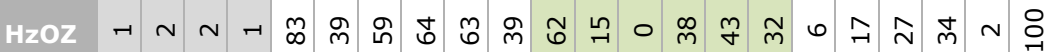

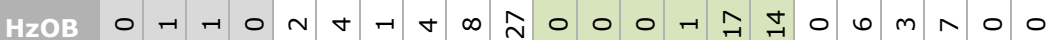

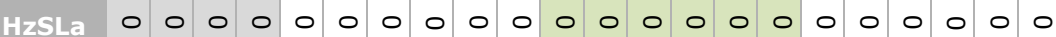

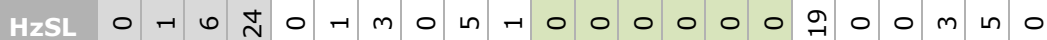

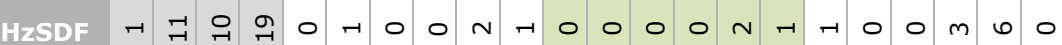
HzSX 0 h

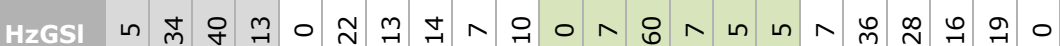

Hzesa $\stackrel{n}{m} n$ h

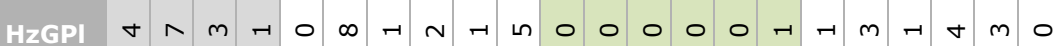

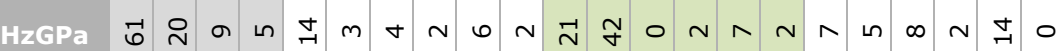

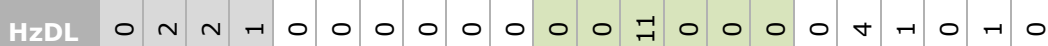

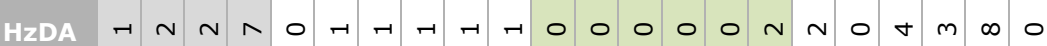

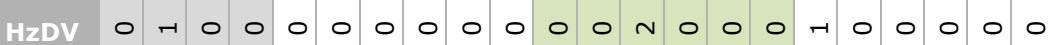

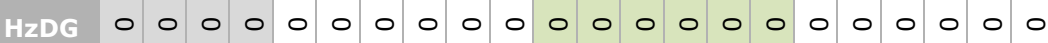
HzBV 00000000000000000000000000

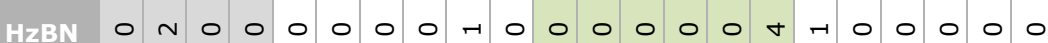

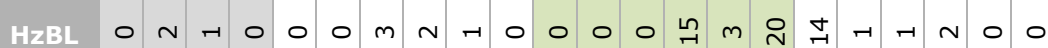

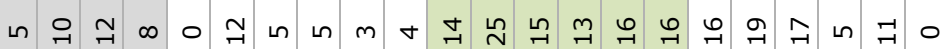




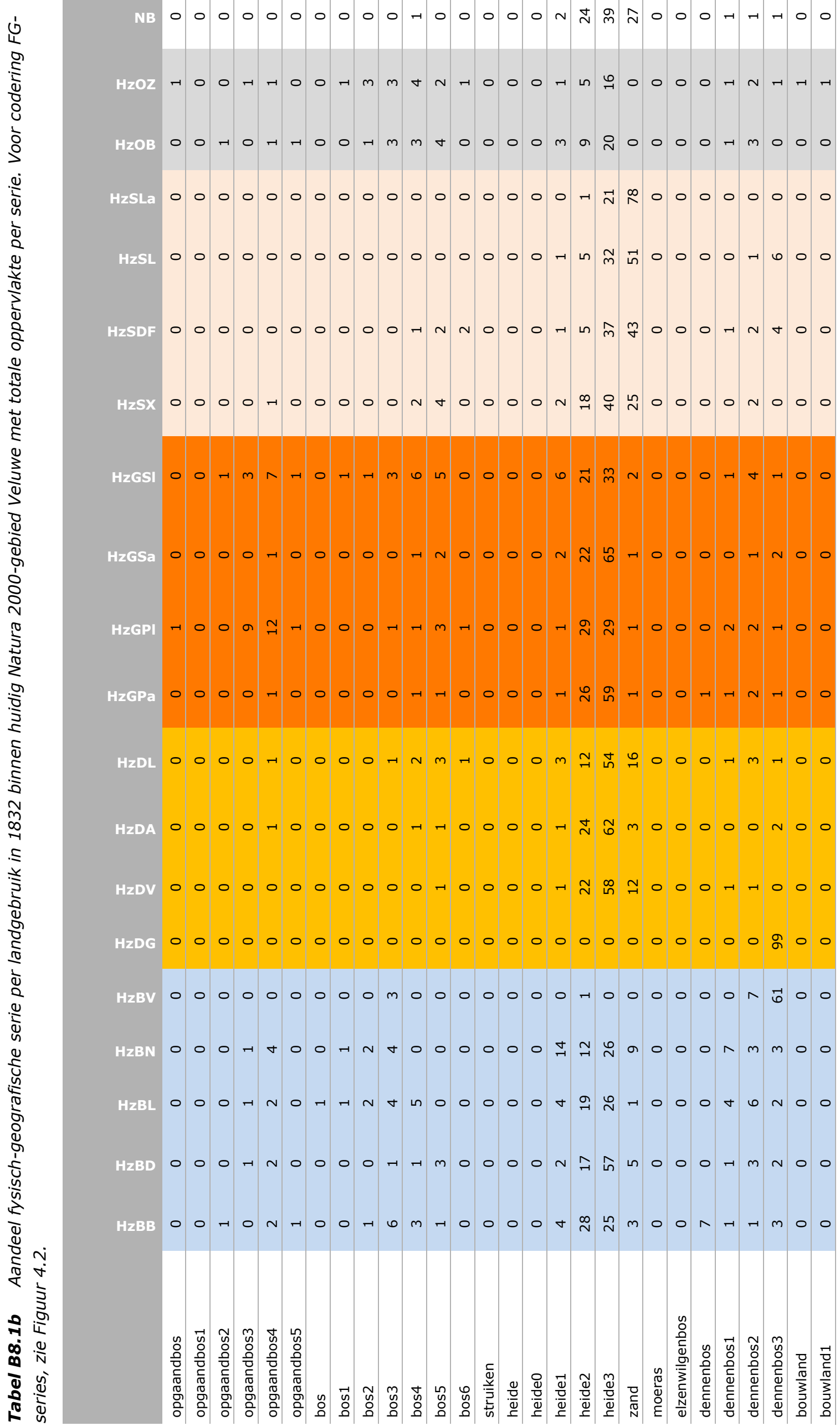




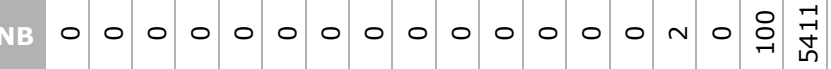

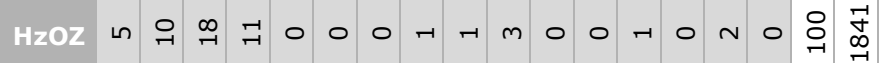

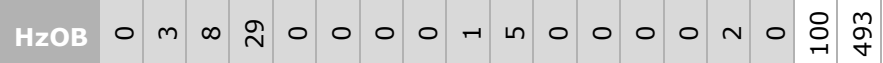

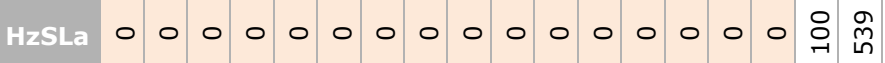

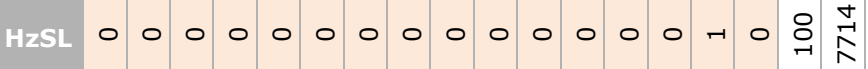
HZSDF $00000000000000 h 0 \frac{1}{0} \frac{1}{9}$

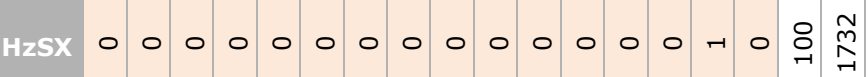

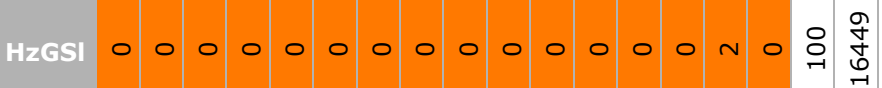

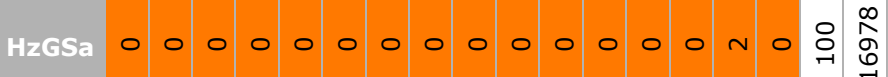

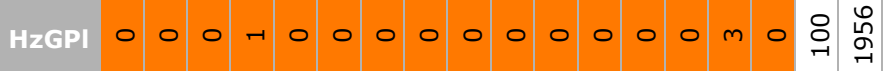

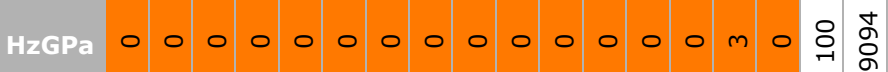

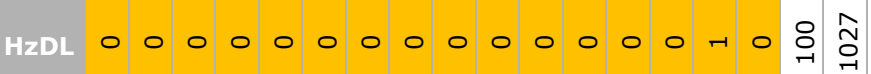
HzZA $0000000000000000 n$ N HzDV $0000000000000000 N$ HzDG 0 O 0000000000110000000 HzBV 0 h 000000000000000000

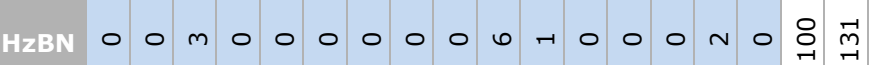
HzBBL n N n HzBD $00000000000000 n 0 \frac{1}{8}$ HzBBB 0 O 0 O 0 O 0 o 0 h

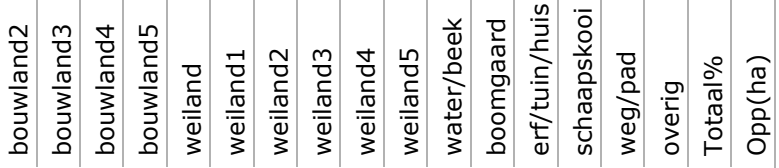




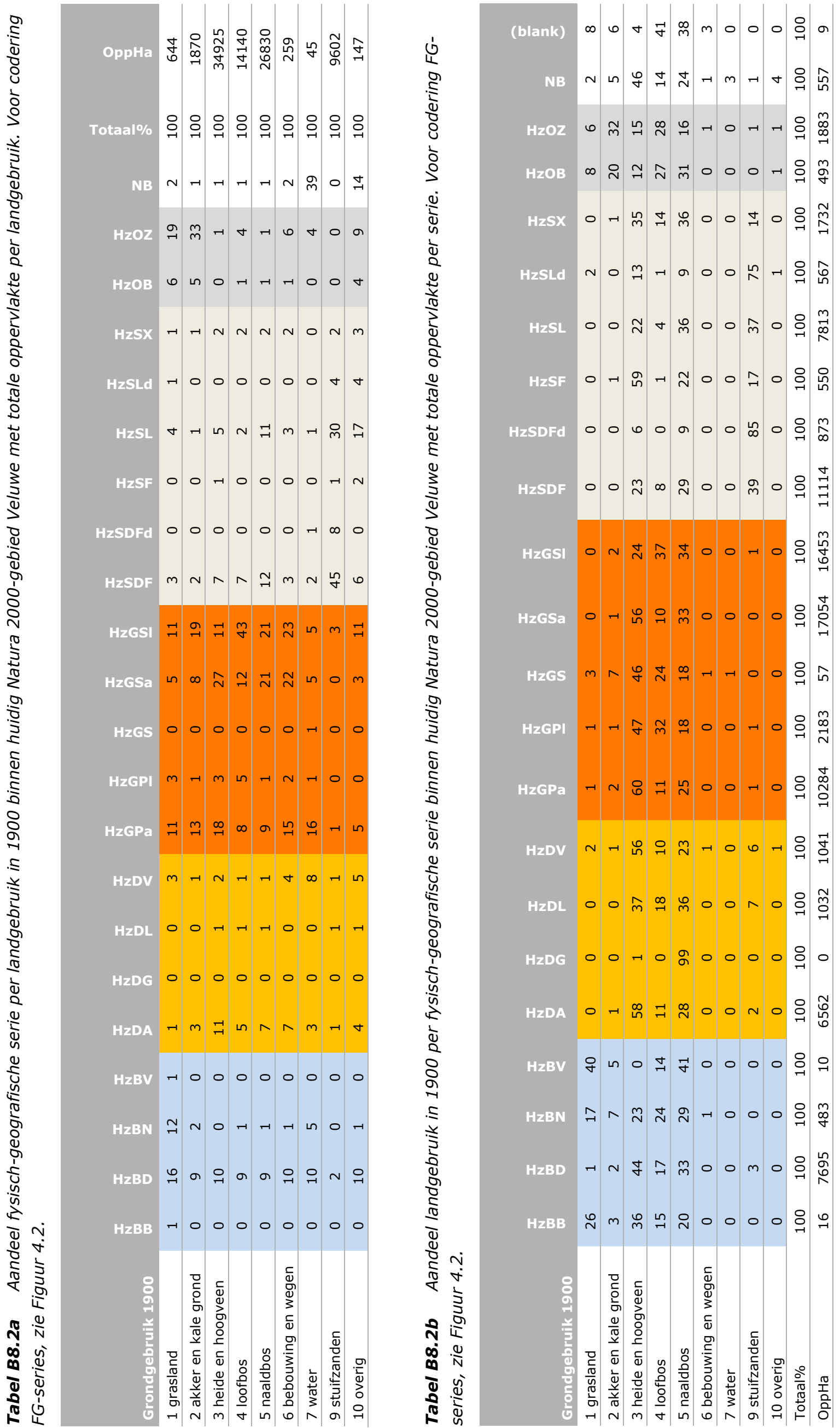




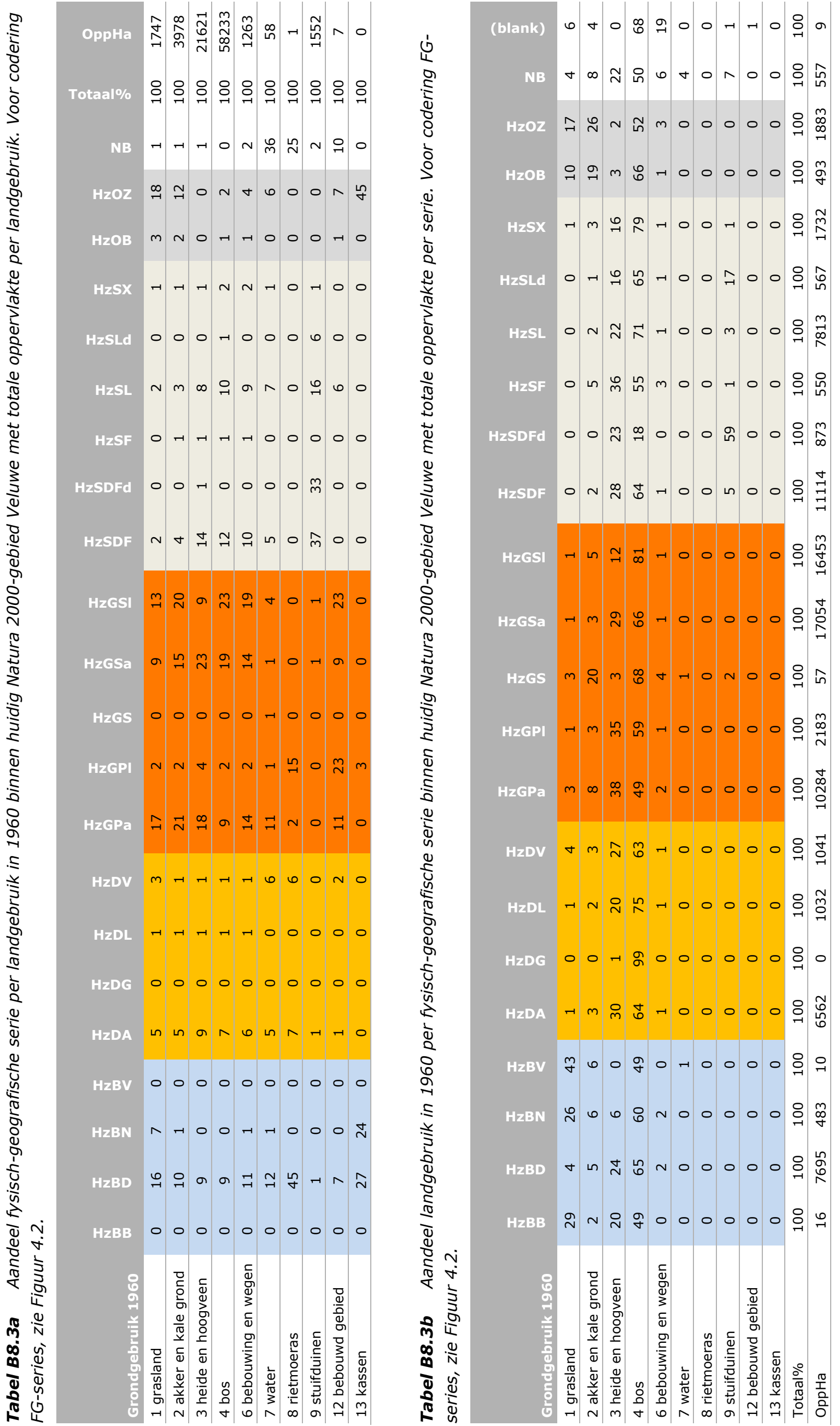




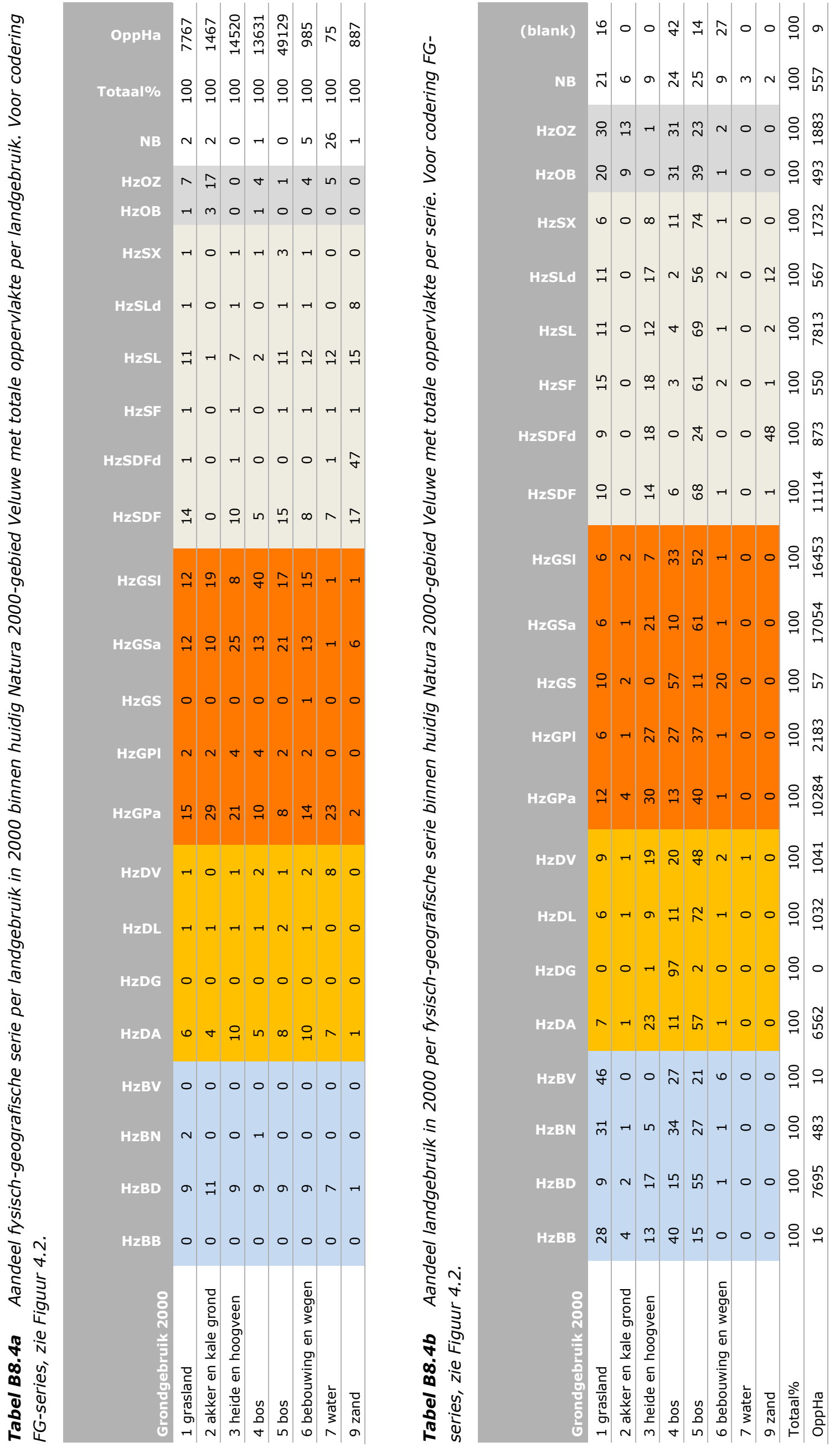


Wageningen Environmental Research Rapport 3036 | 113 
Wageningen Environmental Research Postbus 47

6700 AA Wageningen

T 0317480700

www.wur.nl/environmental-research

Wageningen Environmental Research Rapport 3036

ISSN 1566-7197
De missie van Wageningen University \& Research is 'To explore the potential of nature to improve the quality of life'. Binnen Wageningen University \& Research bundelen Wageningen University en gespecialiseerde onderzoeksinstituten van Stichting Wageningen Research hun krachten om bij te dragen aan de oplossing van belangrijke vragen in het domein van gezonde voeding en leefomgeving. Met ongeveer 30 vestigingen, 6.500 medewerkers ( $5.500 \mathrm{fte}$ ) en 12.500 studenten behoort Wageningen University \& Research wereldwijd tot de aansprekende kennisinstellingen binnen haar domein. De integrale benadering van de vraagstukken en de samenwerking tussen verschillende disciplines vormen het hart van de unieke Wageningen aanpak. 


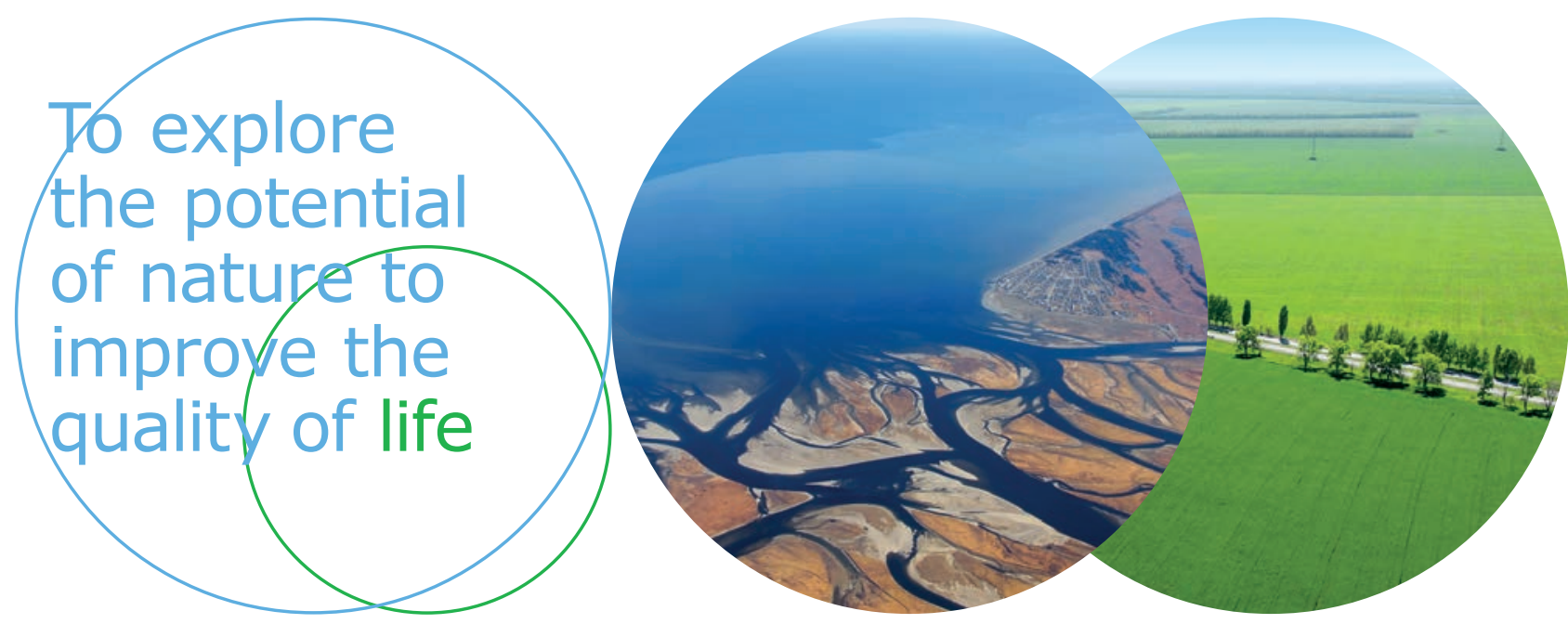

Wageningen Environmental Research Postbus 47

$6700 \mathrm{AB}$ Wageningen

T 317480700

www.wur.nl/environmental-research

Rapport 3036

ISSN 1566-7197
De missie van Wageningen University \& Research is 'To explore the potential of nature to improve the quality of life'. Binnen Wageningen University \& Research bundelen Wageningen University en gespecialiseerde onderzoeksinstituten van Stichting Wageningen Research hun krachten om bij te dragen aan de oplossing van belangrijke vragen in het domein van gezonde voeding en leefomgeving. Met ongeveer 30 vestigingen, 6.500 medewerkers ( $5.000 \mathrm{fte}$ ) en 12.500 studenten behoort Wageningen University \& Research wereldwijd tot de aansprekende kennisinstellingen binnen haar domein. De integrale benadering van de vraagstukken en de samenwerking tussen verschillende disciplines vormen het hart van de unieke Wageningen aanpak. 